\title{
MÁRCIA DOS SANTOS FERREIRA
}

\section{O CENTRO REGIONAL DE PESQUISAS EDUCACIONAIS DE SÃO PAULO (1956/1961)}

Dissertação apresentada ao Curso de Mestrado da Faculdade de Educação da Universidade de São Paulo, como exigência parcial para obtenção do título de Mestre em Educação. Área de concentração: Estado, Sociedade e Educação. Orientador: Prof. Dr. Celso de Rui Beisiegel.

Universidade de São Paulo 
Agradeço às seguintes pessoas que prestaram colaboração fundamental para a realização deste trabalho: Niuvenius Paoli, Celso Beisiegel, José Mário Pires Azanha, Jorge Nagle, Renato Jardim Moreira, Haydée Roveratti, Maria do Carmo Guedes, Luis Contier e Eugênio César Bertoncini.

Esta pesquisa foi realizada com o apoio financeiro da Fundação de Amparo à Pesquisa do Estado de São Paulo (FAPESP). 
Comissão Julgadora

Prof. Dr. Celso de Rui Beisiegel (orientador).

Prof. Dr. Marcus Vinicius da Cunha.

Prof. ${ }^{\text {a Dr. }}{ }^{a}$ Diana Gonçalves Vidal. 


\section{SUMÁRIO}

\begin{tabular}{|c|c|}
\hline RESUMO. & 7 \\
\hline INTRODUÇÃO. & 11 \\
\hline $\begin{array}{l}\text { CAPÍTULO 1. A idealização e a institucionalização do Centro Brasileiro e do Centro } \\
\text { Regional de Pesquisas Educacionais de São Paulo (CBPE e CRPE/SP). }\end{array}$ & 17 \\
\hline 1. Os antecedentes da criação do Centro Brasileiro de Pesquisas Educacionais. & 17 \\
\hline $\begin{array}{l}\text { 2. O processo de criação do Centro Brasileiro e dos Centros Regionais de } \\
\text { Pesquisas Educacionais. }\end{array}$ & 19 \\
\hline 3. A organização formal do CBPE e dos Centros Regionais. & 24 \\
\hline 4. O Centro Regional de Pesquisas Educacionais de São Paulo. & 27 \\
\hline CAPÍTULO 2. Cursos e Seminários. & 33 \\
\hline 1. I Seminário para Professores Primários. & 33 \\
\hline 1.1. Professores e Cursos. & 34 \\
\hline 1.2. Conferências. & 35 \\
\hline 2. Os Cursos de Especialistas em Educação para a América Latina (CEEAL) & 36 \\
\hline 2.1. Antecedentes. & 37 \\
\hline 2.2. Organização geral dos Cursos. & 38 \\
\hline 2.3. I CEEAL. & 39 \\
\hline 2.4. II CEEAL. & 41 \\
\hline 2.5. III CEEAL. & 42 \\
\hline 2.6. IV CEEAL. & 43 \\
\hline 3. Curso para Delegados de Ensino. & 45 \\
\hline $\begin{array}{l}\text { 4. Curso Intensivo para Inspetores Escolares do Ensino Primário no Estado de } \\
\text { São Paulo. }\end{array}$ & 45 \\
\hline 5. Cursos de Férias para o Magistério Estadual. & 47 \\
\hline 6. Cursos do Serviço de Recursos Audiovisuais. & 48 \\
\hline 7. I Seminário para Treinamento de Pessoal para Pesquisas Educacionais. & 48 \\
\hline Considerações Gerais. & 50 \\
\hline CAPÍTULO 3. Pesquisas, Levantamentos e Estudos. & 52 \\
\hline 1. Levantamento do Ensino Primário (LEP). & 53 \\
\hline $\begin{array}{l}\text { 2. Levantamento do Ensino Secundário (oficial) e Normal (oficial e particular) } \\
\text { do Estado de São Paulo. }\end{array}$ & 60 \\
\hline 3. Ficha de Observação de Alunos (FOA). & 62 \\
\hline 4. Escalas de Escolaridade. & 64 \\
\hline $\begin{array}{l}\text { 5. Estudo experimental sobre o rendimento na solução de problemas aritméticos } \\
\text { na escola primária. }\end{array}$ & 68 \\
\hline $\begin{array}{l}\text { 6. Estudo experimental sobre os efeitos de alterações na forma de apresentação } \\
\text { de problemas aritméticos. }\end{array}$ & 69 \\
\hline 7. Estudo sobre o vocabulário da criança na escola primária. & 70 \\
\hline 8. Estudos sobre estatísticas educacionais. & 70 \\
\hline 9. Levantamento sobre o Inspetor Escolar do Estado de São Paulo. & 73 \\
\hline 10. Associações de "nissei” em São Paulo. & 75 \\
\hline
\end{tabular}




\begin{tabular}{|c|c|}
\hline 11. Análise do conteúdo dos livros de leitura. & 75 \\
\hline $\begin{array}{l}\text { 12. Ocupação dos pais dos candidatos às escolas industriais na cidade de São } \\
\text { Paulo. }\end{array}$ & 76 \\
\hline 13. Estudo sobre a promoção automática na escola primária. & 77 \\
\hline 14. Estudo piloto de uma escola secundária. & 78 \\
\hline 15. Planejamento da expansão da rede escolar primária de Presidente Prudente. & 80 \\
\hline 16. Colaboração na "Campanha pela instrução primária na cidade de Santos". & 81 \\
\hline 17. Levantamento da rede escolar na cidade de São Paulo. & 82 \\
\hline 18. Política e Expansão da Rede Escolar do Estado de São Paulo. & 83 \\
\hline Considerações Gerais. & 84 \\
\hline $\begin{array}{l}\text { CAPÍTULO 4. Outras atividades da divisão de Aperfeiçoamento do Magistério } \\
\text { (DAM). }\end{array}$ & 88 \\
\hline 1. Classes Experimentais. & 88 \\
\hline 2. Serviço de Recursos Audiovisuais. & 89 \\
\hline 3. Seleção de professores e bolsistas. & 91 \\
\hline CAPÍTULO 5. Serviços Administrativos e Serviços Técnicos Auxiliares. & 92 \\
\hline 1. Secretaria Executiva. & 92 \\
\hline 2. Biblioteca. & 93 \\
\hline 3. Seção de Publicações. & 94 \\
\hline 4. Serviço de Estatística. & 94 \\
\hline CAPÍTULO 6. Os principais temas discutidos. & 97 \\
\hline 1. Educação e Ciências Sociais. & 98 \\
\hline $\begin{array}{l}\text { 1.1. Comentários sobre o tema: A "sociologização" do pensamento } \\
\text { pedagógico brasileiro. }\end{array}$ & 104 \\
\hline 2. Desenvolvimento Sócio-econômico, Mudança Cultural e Educação. & 107 \\
\hline 2.1. Comentários sobre o tema. & 115 \\
\hline 3. Pesquisa Científica e Planejamento Educacional. & 116 \\
\hline 3.1. Pesquisa científica aplicada à educação. & 117 \\
\hline 3.2. Diversos aspectos do planejamento educacional. & 118 \\
\hline 3.3. Os levantamentos e o planejamento educacional. & 120 \\
\hline 3.4. Comentários sobre o tema. & 122 \\
\hline 4. A tramitação da Lei de Diretrizes e Bases da Educação Nacional. & 124 \\
\hline 4.1. Comentários sobre o tema. & 131 \\
\hline Considerações gerais. & 133 \\
\hline $\begin{array}{l}\text { CAPÍTULO 7. O Centro Regional de Pesquisas Educacionais de São Paulo e a } \\
\text { ideologia nacional desenvolvimentista. }\end{array}$ & 137 \\
\hline 1. A ideologia desenvolvimentista do governo Juscelino Kubitschek. & 137 \\
\hline $\begin{array}{l}\text { 1.1. Ideologia desenvolvimentista: ordem social e crescimento } \\
\text { econômico. }\end{array}$ & 138 \\
\hline $\begin{array}{l}\text { 1.2. A política educacional e sua adequação ao desenvolvimento } \\
\text { econômico. }\end{array}$ & 143 \\
\hline 2. O ISEB e a ideologia nacional-desenvolvimentista. & 147 \\
\hline 2.1. A ideologia do desenvolvimento. & 148 \\
\hline
\end{tabular}




\begin{tabular}{|l|c|}
\hline \multicolumn{1}{|c|}{ 2.1.1. Algumas noções básicas da ideologia isebiana. } & 149 \\
\hline 2.2. O ISEB e o governo Kubitschek. & 152 \\
\hline 2.3. Divergências entre os intelectuais paulistas e o ISEB. & 153 \\
\hline 3. O CRPE/SP e o ISEB. & 158 \\
\hline Considerações gerais. & 160 \\
\hline CONCLUSÃO. & 163 \\
\hline ANEXO A - Ficha de Observação de Alunos. & \\
\hline ANEXO B - O Simpósio sobre Problemas Educacionais Brasileiros. & 170 \\
\hline ANEXO C - Carta de Anísio Teixeira a Fernando de Azevedo, de 24/10/1956. & 174 \\
\hline & 178 \\
\hline BIBLIOGRAFIA. & 180 \\
\hline & \\
\hline CRÉDITOS DA AUTORA. & 195 \\
\hline & \\
\hline
\end{tabular}




\section{RESUMO.}

Trata-se de um levantamento documental e bibliográfico realizado com a finalidade de elaboração de um quadro descritivo das atividades realizadas no Centro Regional de Pesquisas Educacionais de São Paulo (CRPE/SP), durante os anos de 1956 a 1961, período em que Fernando de Azevedo foi seu Diretor Geral. Através do levantamento das pesquisas, cursos e demais atividades desenvolvidas pelo CRPE/SP no período correspondente à sua instalação e primeiros anos de funcionamento, destaca-se a importância de Anísio Teixeira na criação desta instituição que tinha como objetivo central a reconstrução educacional brasileira através da utilização dos conhecimentos provenientes das ciências sociais. No entender de Anísio Teixeira e do grupo de intelectuais que se reuniu em função das atividades que se desenvolveram no Centro - Fernando de Azevedo, Florestan Fernandes, Dante Moreira Leite, entre outros - as práticas educacionais alcançariam condições científicas na medida em que se utilizassem do instrumental teórico e metodológico próprio das ciências sociais para a investigação e reflexão a respeito de seus problemas. O trabalho de descrição das atividades desenvolvidas no Centro permitiu a seleção de quatro temas que se mostraram recorrentes nos trabalhos produzidos pelos intelectuais vinculados à essa instituição. São eles: Educação e Ciências Sociais; Desenvolvimento Sócio-Econômico, Mudança Cultural e Educação; Pesquisa Cientifica e Planejamento Educacional; e, Tramitação da Lei de Diretrizes e Bases da Educação Nacional. Acrescenta-se ao trabalho descritivo e à apresentação dos temas mais discutidos algumas considerações a respeito do contexto ideológico da época, abordando o desenvolvimentismo do governo Juscelino Kubitschek, a ideologia do desenvolvimento do ISEB e o posicionamento do Centro em relação às discussões que aconteciam. Em decorrência disso, também são destacadas as divergências entre os intelectuais paulistas e isebianos, assim como o vínculo existente entre o Centro e a Faculdade de Filosofia, Ciências e Letras da USP. Além da utilização da bibliografia existente a respeito do Centro, o levantamento documental realizou-se através da consulta ao Arquivo CRPE/SP do Centro de Memória da Educação da USP; ao Arquivo Fernando de Azevedo do Instituto de Estudos Brasileiros da USP; ao Arquivo Anísio Teixeira do Centro de Pesquisa e Documentação de História Contemporânea do Brasil/CPDOC da Fundação Getúlio Vargas; aos Relatórios Anuais de Atividades do Centro, pertencentes ao Arquivo Histórico do INEP; aos números da revista Pesquisa e Planejamento (boletim do CRPE/SP) e Educação e Ciências Sociais (boletim do CBPE) referentes ao período estudado; e, à série Estudos e Documentos (publicada pelo CRPE/SP). A 
descrição das atividades do Centro e o estudo do vínculo existente entre esta instituição e a Faculdade de Filosofia da USP possibilitou a avaliação do seu sucesso no cumprimento dos objetivos estabelecidos no início de suas atividades, assim como permitiu avaliar o seu papel no processo de formação de pesquisadores que se dedicariam ao estudos dos problemas educacionais brasileiros a partir de então.

Palavras-chave: pesquisa educacional, ciências sociais e educação, desenvolvimento, reconstrução educacional, planejamento educacional, levantamentos. 


\section{ABSTRACT.}

A survey of documents and bibliography was made, for the purpose of elaborating a descriptive overview of the activities occurring in the Centro Regional de Pesquisas Educacionais de São Paulo (CRPE/SP) - Regional Center for Education Researches of São Paulo - during the years from 1956 to 1961, the period when Fernando de Azevedo was the General Director. By a survey of the researches, courses and other activities developed by the CRPE/SP, in the period corresponding to its establishment and first years of operation, it is presented the importance of Anísio Teixeira in the creation of this institution that had as its main objective the reconstruction of Brazilian education through the use of knowledge obtained from the social sciences. The concepts of Anísio Teixeira and the group of scholars gathered for the activities taking place at the Center - Fernando de Azevedo, Florestan Fernandes, Dante Moreira Leite, among others - were that educational practices would reach scientific status as they used theoretical and methodological means, typical of the social sciences, to investigate and ponder about its problems. The work of description of the activities developed at the Center allowed the selection of four themes that have showed up repeatedly in the work produced by the scholars associated with the institution. They are: Education and Social Sciences; Socioeconomic Development, Cultural Changes and Education; Scientific Research and Educational Planning; and Procedural Steps of the Law of Policies and Basis of Nationwide Education (LDBEN). Added to the descriptive work and presentation of the themes under discussion, there are also considerations about the ideological context of these times, taking into account the drive for development of the Juscelino Kubitschek presidency, the ideology of development of the ISEB and the position of the Center relative to the debates then underway. As a consequence of that, the divergences between "paulistas" and "ISEBian" scholars are also presented, as well as the bonds existing between the Center and the Faculdade de Filosofia, Ciências e Letras da USP. Besides using the available bibliography about the Center, the survey of documents was made by access to the Archives of the CRPE/SP in the Centro de Memória da Educação (Center for the Preservation of the Memories of Education) of USP; the Fernando Azevedo Archives in the Institute Brazilian Studies of USP; the Anísio Teixeira Archives of the Center for Research and Documentation of the Recent History of Brazil (CPDOC) of the Getulio Vargas Foundation; the Annual Reports on the Activities of the Center, in the Historic Files of INEP; to issues of the Pesquisa e Planejamento (Research \& Planning) magazine (bulletin of the 
CRPE/SP) and the Educação e Ciências Sociais (Education \& Social Sciences) magazine (bulletin of the CBPE) published in the period being studied; and the Estudos e Documentos (Studies \& Documents) series (published by the CRPE/SP). The description of the activities of the Center and the study of the bond present between the institution and the Faculdade de Filosofia da USP enabled us to evaluate its success in the achievement of the objectives set at the beginning of its activities, and also allowed an assessment of its role in the process of formation of researchers who dedicated themselves to the study of Brazilian educational problems from that time onwards.

Keywords: educational research, Social Sciences and Education, development, reconstruction of education, planning of education, surveys. 


\section{INTRODUÇÃO.}

"Pesquisa no Brasil lembra sempre coisas feitas um pouco no ar. Um prédio de cerca de 200 mts. de longo e 20 de largo para pesquisas parece um absurdo. E pesquisas de educação? Ainda mais. É que não pensam que o setor de documentação, o de programas, o de psicologia, o de testes e medidas, o de administração, o de livros $e$ material do ensino são imensos departamentos, que o meu Centro, apesar de grande, acabará por não comportar. Medicina é, sem dúvida, um imenso campo de pesquisas. Pois bem: o de educação não é, mas devia ser bem maior". . (Anísio Teixeira)

A comparação entre a Medicina - "a arte de curar" - e a Educação - "a arte de educar" - apresentada no trecho acima, seria mais uma vez utilizada por Anísio Teixeira no artigo Ciência e arte de educar, escrito para o encerramento do I Seminário de Professores Primários, realizado no Centro Regional de Pesquisas Educacionais de São Paulo, no começo de 1957.

Para Anísio Teixeira, a Educação deveria passar por uma transformação semelhante a sofrida pela Medicina que, ao longo dos séculos XIX e XX, com o auxílio do desenvolvimento das ciências que lhe serviam de base, elaborou métodos próprios de investigação e foi afastando-se da "intuição", tornando-se cada vez mais científica.

O Centro Regional de Pesquisas Educacionais de São Paulo (CRPE/SP), criado em 1956, foi parte de um projeto de Anísio Teixeira que pretendia fazer com que as atividades educacionais alcançassem condições científicas, através da colaboração das ciências sociais. Assim como os problemas das ciências biológicas humanas se originam da medicina, as práticas educacionais poderiam dar origem aos problemas investigados pelas ciências sociais.

A proposta de criação de Centros de Pesquisas Educacionais espalhados pelo Brasil enfrentou, entretanto, alguns obstáculos práticos para sua implementação. A dotação de verbas orçamentárias e edificações existentes para a implantação de Centros destinados à pesquisa educacional não era coisa aceita naturalmente pelos políticos da época: parecia um absurdo destinar às atividades de pesquisa, verbas que poderiam ser destinadas à extensão da rede escolar existente.

Fernando de Azevedo, primeiro Diretor do Centro Regional paulista, no discurso de inauguração do Centro, preocupava-se em convencer as "esferas governamentais" da importância da realização de pesquisas para a solução dos problemas educacionais brasileiros

\footnotetext{
${ }^{1}$ Trecho de Carta de Anísio TEIXEIRA a Fernando de Azevedo, de 05 de junho de 1956, Arquivo Fernando de Azevedo, IEB/USP (grifo do autor).
} 
e da necessidade de apoio de toda a sociedade às atividades que seriam desenvolvidas naquela instituição:

“O que se dá aos Centros não se subtrai, mas se acrescenta à solução dos problemas da educação nacional. Gasta-se hoje, mas para economizar depois. Gasta-se, não importa se pouco ou muito, nas atividades científicas de pesquisa, de levantamento de situações, de colocação de problemas, de procura de soluções adequadas, mas para cortar rente nas despesas e reorganização, para aplainar dificuldades, para cercear abusos, contra sensos e erros, de consequências irreparáveis",

Acreditando na colaboração que as ciências sociais poderiam dar à educação, Fernando de Azevedo, no mesmo discurso, comparou a forma alongada do edifício destinado ao Centro à uma "ponta de lança", que introduziria uma política científica de educação no país.

As características de localização deste prédio atribuíam ao Centro algumas particularidades. O prédio construído - de 200 metros de extensão por 30 de largura - e o que ainda estava em construção - que teria cinco pavimentos - localizavam-se no terreno destinado à Cidade Universitária da USP, no bairro do Butantã, em São Paulo. Em 1955, o acesso à essa área dava-se pelo Instituto Butantã e as condições das estradas e ruas circundantes exigiam que, em dias de chuva, um caminhão fosse utilizado para o transporte de funcionários. Além disso, a área do Butantã era distante do centro da cidade, exigindo um grande esforço das pessoas que queriam se dirigir ao Centro de Pesquisas Educacionais. A seguinte descrição, feita por Fernando de Azevedo, consegue dimensionar melhor os problemas enfrentados pelas pessoas envolvidas no processo de instalação do Centro:

"Se se considerarem as sérias dificuldades decorrentes da distância em que fica o Centro Regional de Pesquisas Educacionais, com sede na Cidade Universitária, e do péssimo estado em que ainda se acham estradas e ruas que dão acesso ao Centro, $e$ estão sendo preparadas para serem macadamizadas ou asfaltadas, poder-se-á ter uma idéia de quanto nos custou não só instalar e equipar o edifício de tudo o que era necessário como também atrair funcionários dispostos a enfrentar essa rude situação. Grandes distâncias; dificuldades de transporte, sobretudo em dias de chuvas prolongadas em que os caminhos, nas proximidades, se tornam quase intransitáveis; falta de indicações locais precisas, como de comunicações telefônicas, tudo isso concorria para embaraçar ou retardar a entrega de material pelos fornecedores e a entrada de funcionários que tinham, não raramente, de fazer sacrifícios para estarem à hora exata no Centro de Pesquisas"3.

\footnotetext{
${ }^{2}$ Fernando de AZEVEDO, Inauguração do CRPE, Pesquisa e Planejamento, n. 1, p. 06-7.

${ }^{3}$ Trecho de Carta de Fernando de AZEVEDO a Anísio Teixeira, de 24 de janeiro de 1957, Arquivo Histórico do INEP.
} 
Se a localização do Centro na área que se destinaria à Cidade Universitária da USP lhe causou alguns transtornos nas etapas iniciais de sua instalação, por outro lado, ela seria reflexo do estreito vínculo existente entre essas duas instituições. Desde que concebeu a idéia de criação de Centros Regionais destinados à pesquisa educacional no Brasil, Anísio Teixeira os imaginava como necessariamente vinculados às Universidades locais. Em São Paulo, o Centro Regional surgiu através de um convênio celebrado entre o INEP e a USP. A Universidade comprometia-se a manter o Centro e fornecer-lhe o Diretor e os membros do seu Conselho Administrativo, escolhidos entre o corpo docente dos Departamentos de Pedagogia, Sociologia e Antropologia da Faculdade de Filosofia, Ciências e Letras ${ }^{4}$. Na prática, além do Diretor e do Conselho, quase todas as pessoas envolvidas com as atividades do Centro, no período de 1956 a 1961, eram ou haviam sido vinculadas à Faculdade de Filosofia da USP, seja como professores, alunos ou funcionários.

O período de 1956 a 1961 foi escolhido para delimitar esta pesquisa por ser o período correspondente à primeira administração do Centro, durante a qual Fernando de Azevedo foi o Diretor. Neste período, o Centro foi instalado, seus objetivos e plano de trabalho foram estabelecidos e os primeiros cursos e pesquisas foram propostos e se iniciaram. Entre os anos de 1960 e 1961, além da mudança do Diretor Geral, houve significativas mudanças no corpo técnico e no quadro de Diretores de Divisão do Centro, caracterizando um novo período de atividades que não será objeto de estudo deste trabalho.

A pesquisa bibliográfica e documental realizada procurou agregar elementos que contribuíssem para a construção de um quadro descritivo das atividades desenvolvidas no Centro Regional de Pesquisas Educacionais de São Paulo, no período de 1956 a 1961, acompanhado de algumas indicações a respeito da ideologia dominante na época e suas relações com os propósitos deste Centro de Pesquisas.

A criação do CRPE/SP, entretanto, não aconteceu de forma isolada, ela fez parte de um processo que envolveu a criação do Centro Brasileiro de Pesquisas Educacionais e outros quatro Centros Regionais, cujo objetivo principal era colaborar para a elaboração de uma política educacional para o país, através da realização de pesquisas sociais e educacionais. Os elementos que colaboraram para a realização desse processo, seus antecedentes e resultados são apresentados na primeira parte deste trabalho.

\footnotetext{
${ }^{4}$ Um evento representativo do estreito vínculo existente entre essas instituições foi a realização de uma sessão da Congregação da Faculdade de Filosofia no salão de leitura do Centro, no dia 08 de novembro de 1957. Esta foi a primeira reunião de uma Faculdade da Universidade de São Paulo realizada na Cidade Universitária. Cf. Relatório de Atividades do CRPE/SP - 1957, p. 05.
} 
A segunda parte tem o objetivo de descrever os cursos e seminários realizados no Centro, durante o período estudado. Nela são apresentados os sete diferentes cursos oferecidos e as quatro primeiras versões do Curso de Especialistas em Educação para a América Latina realizado pela Divisão de Aperfeiçoamento do Magistério, em parceria com a UNESCO, a partir de 1958. Os cursos, em geral, buscavam o aprimoramento da formação profissional dos professores, diretores, delegados de ensino e inspetores ligados ao Ensino Primário.

As pesquisas, levantamentos e estudos propostos pela Divisão de Estudos e Pesquisas Sociais e pela Divisão de Estudos e Pesquisas Educacionais são descritos na terceira parte deste trabalho. Dezoito pesquisas foram iniciadas no período de 1956 a 1961, dentre as quais destacam-se o Levantamento do Ensino Primário, a Ficha de Observação de Alunos e as Escalas de Escolaridade.

As atividades da Divisão de Aperfeiçoamento do Magistério que não se enquadravam como cursos foram reunidas na quarta parte do trabalho. Essa Divisão era responsável pelo funcionamento das Classes Experimentais, pelo Serviço de Recursos Audiovisuais e pela realização de alguns processos seletivos para professores e bolsistas.

No quinto capítulo encontram-se, de forma sumária, informações sobre as atividades da Secretaria, da Biblioteca e do Serviço de Estatística (criado em 1961). A observação dessas atividades permitem a melhor compreensão a respeito de características particulares das instalações do Centro, o andamento dos serviços administrativos, a rotina dos serviços da Biblioteca, da Seção de Publicações e dos trabalhos das Divisões de Pesquisa encaminhados ao Serviço de Estatística para análise.

O contato com os documentos que possibilitaram a descrição das atividades desenvolvidas pelo Centro, no período de 1956 a 1961, permitiu a seleção de alguns temas que se mostraram recorrentes nos trabalhos produzidos pelos intelectuais vinculados à essa instituição. Os temas selecionados, apresentados no sexto capítulo, são: Educação e Ciências Sociais; Desenvolvimento Sócio-Econômico, Mudança Cultural e Educação; Pesquisa Científica e Planejamento Educacional; e, Tramitação da Lei de Diretrizes e Bases da Educação Nacional. A apresentação desses temas, da forma como eles foram tratados pelas pessoas vinculadas ao Centro, procura caracterizar as preocupações intelectuais que justificavam as atividades de pesquisa e de aperfeiçoamento do magistério que seriam desenvolvidas no período.

O último capítulo apresenta alguns aspectos do contexto ideológico da época, abordando o desenvolvimentismo do governo Juscelino Kubitschek, a ideologia do 
desenvolvimento do ISEB e o posicionamento do CRPE/SP em relação às discussões que aconteciam. Nesse capítulo, as divergências entre os intelectuais paulistas e isebianos são destacadas, assim como o vínculo existente entre o CRPE/SP e a Faculdade de Filosofia da USP.

Além da bibliografia existente a respeito do Centro Brasileiro e do Centro Regional de Pesquisas Educacionais de São Paulo, a documentação utilizada para elaboração do quadro descritivo das atividades desenvolvidas pelo Centro foi composta pelos seguintes elementos:

1. Relatórios Anuais de Atividades do Centro Regional de Pesquisas Educacionais de São Paulo, de 1956 a 1961, obtidos junto ao Arquivo Histórico do INEP. Estes relatórios eram elaborados pelos Diretores das Divisões de Estudos e Pesquisas Educacionais, Sociais e de Aperfeiçoamento do Magistério, pelos chefes dos Serviços Administrativos (Secretaria Executiva, Secretaria, Contabilidade, Tesouraria e Almoxarifado), Serviços Técnicos Auxiliares (Biblioteca e Seção de Publicações) e Serviço de Estatística, sendo encaminhados para a direção do INEP.

2. Os cinco primeiros números da revista Pesquisa e Planejamento - boletim do Centro Regional paulista - publicados de 1957 a 1962. Esta revista foi publicada com periodicidade anual pelo CRPE/SP, a partir de junho de 1957. A periodicidade da publicação foi quebrada em 1961, sendo retomada a partir de 1962. A edição de 1962 foi incluída na documentação utilizada por conter dados referentes ao ano anterior, uma vez que a revista era publicada no mês de junho, mas os artigos que a compunham eram recolhidos para edição no mês de fevereiro sendo, portanto, referentes às atividades e debates de 1961 .

3. Os 21 números publicados da revista Educação e Ciências Sociais - boletim do Centro Brasileiro de Pesquisas Educacionais. Esta revista foi publicada com periodicidade quadrimestral, de março de 1956 a dezembro de 1962, divulgando as atividades desenvolvidas e os artigos produzidos pelos pesquisadores do CBPE e colaborações de pesquisadores dos Centros Regionais - inclusive o CRPE/SP - além de conter uma seção chamada "Noticiário", na qual um resumo das atividades de cada Centro Regional era publicada.

4. Os dois volumes da série Estudos e Documentos - publicada pelo CRPE/SP - que divulgaram o conteúdo dos trabalhos apresentados no Simpósio sobre Problemas Educacionais Brasileiros, realizado no Centro Regional paulista, em 1959. Esses volumes foram publicados em 1967 e 1968. 
5. Artigos da Revista Brasileira de Estudos Pedagógicos que continham informações relativas ao processo de criação do Centro Brasileiro e dos Centros Regionais de Pesquisas Educacionais e que reproduziam documentos referentes à criação desses Centros.

6. Documentos obtidos no arquivo Fernando de Azevedo do Instituto de Estudos Brasileiros da USP. Esses documentos referiam-se sobretudo a cartas recebidas por Fernando de Azevedo durante o período em que foi Diretor do CRPE/SP e relatórios e portarias referentes ao mesmo período.

7. Documentos obtidos no Arquivo CRPE/SP do Centro de Memória da Educação da Faculdade de Educação da USP. Além de cópias documentos oficiais, este arquivo dispõe de diversas reproduções de artigos produzidos por pesquisadores do Centro, artigos de jornais e relatórios de pesquisas realizadas no período de 1956 a 1961.

8. Documentos obtidos no Arquivo Anísio Teixeira do Centro de Pesquisa e Documentação de História Contemporânea do Brasil da Fundação Getúlio Vargas (CPDOC/FGV). Neste arquivo encontram-se cópias de cartas escritas por Anísio Teixeira e alguns documentos relativos aos Centros de Pesquisas Educacionais.

Este conjunto de documentos, acrescidos de informações sobre o governo Juscelino Kubitschek, sobre a ideologia isebiana e sobre a Faculdade de Filosofia, Ciências e Letras da USP, possibilitou a descrição das pesquisas e cursos que ocorreram no Centro Regional Paulista durante o período estudado, o levantamento das principais idéias discutidas pelos intelectuais que participaram daquele projeto, e o estabelecimento de relações entre essas idéias e a ideologia vigente na época, com o objetivo de agregar elementos que contribuíssem para um melhor entendimento a respeito da pesquisa educacional que foi feita no Brasil a partir de então. 


\section{Capítulo 1 - A idealização e a institucionalização do Centro Brasileiro e do Centro Regional de Pesquisas Educacionais de São Paulo (CBPE e CRPE/SP).}

O Centro Regional de Pesquisas Educacionais de São Paulo não foi criado isoladamente. Ele fazia parte de um conjunto de instituições que, subordinadas ao Instituto Nacional de Estudos Pedagógicos (INEP), deveriam realizar pesquisas educacionais em todo o Brasil.

Uma reconstituição histórica da vida do Centro Regional paulista requer, portanto, além das informações referentes à sua própria institucionalização, o levantamento dos aspectos principais que envolveram a criação do Centro Brasileiro de Pesquisas Educacionais e a apresentação dos objetivos que motivaram as pessoas que se dedicaram à sua idealização.

Existem trabalhos que tratam especificamente do Centro Brasileiro ${ }^{1}$. As considerações que serão realizadas a respeito deste tema pretendem apenas apresentar os esclarecimentos julgados indispensáveis para uma melhor compreensão do processo que levou à criação do Centro Regional de Pesquisas Educacionais de São Paulo e das atividades nele desenvolvidas, no período de 1956 a 1961.

\section{Os antecedentes da criação do Centro Brasileiro de Pesquisas Educacionais (CBPE).}

Anísio Teixeira assumiu a direção do Instituto Nacional de Estudos Pedagógicos em 1952. No final de 1955, ele encaminhou ao Ministro da Educação e Cultura um Ofício no qual sugere a criação do Centro Brasileiro e dos Centros Regionais de Pesquisas Educacionais.

Entretanto, os antecedentes do processo que levaria à criação dessas instituições podem ser encontrados algumas décadas antes. Um breve esboço da atuação de Anísio Teixeira na área educacional serve para exemplificar quais seriam os principais elementos dessa nova forma de enfrentar os problemas educacionais brasileiros que se estabelece no país a partir do início dos anos 20.

Anísio Teixeira foi Inspetor Geral do Ensino na Bahia no governo Góes Calmon, de 1924 a 1929, quando fez "o primeiro levantamento global das condições materiais e humanas

\footnotetext{
${ }^{1}$ Refiro-me, especialmente, ao trabalho de Libânia Nacif XAVIER, O Brasil como Laboratório: Educação e Ciências Sociais no projeto do Centro Brasileiro de Pesquisas Educacionais; e aos trabalhos apresentados na coletânea organizada por Ana Waleska MENDONÇA e Zaia BRANDÃO, Por que não lemos Anísio Teixeira? Uma tradição esquecida.
} 
das escolas baianas" ${ }^{, 2}$ que, identificando as necessidades particulares de cada região, colaboraria para o planejamento da educação no estado. Outro cargo assumido por Anísio Teixeira, de 1931 a 1935, foi o de Diretor Geral da Instrução Pública no Distrito Federal, na administração de Pedro Ernesto Batista, oportunidade em que fez "o levantamento das condições materiais e funcionais do ensino oferecido nas escolas públicas"33 e que serviria de base para uma reforma educacional que atingiu "desde a escola primária, à escola secundária e ao ensino de adultos, culminando com a criação de uma universidade municipal, a Universidade do Distrito Federal"4.

Depois de passar um ano na UNESCO, como conselheiro de ensino superior, Anísio Teixeira volta ao Brasil, em 1947, assumindo o cargo de Secretário da Educação na Bahia a convite do governador Otávio Mangabeira (1946-1950). Nesta oportunidade, ele cria dois órgãos: a Divisão de Pesquisas do Departamento de Educação e Cultura da Secretaria de Educação e a Fundação para o Desenvolvimento da Ciência na Bahia, com um Departamento de Ciências Sociais". Através desses órgãos foi desenvolvido o programa de "Pesquisas Sociais Estado da Bahia - Columbia University" que contou com a participação dos etnólogos Charles Wagley e Eduardo Galvão. Também foram desenvolvidas pesquisas em convênio com outras universidades norte-americanas e colaborações com a Escola Livre de Sociologia e Política de São Paulo e com a UNESCO. Charles Wagley e Eduardo Galvão desempenhariam um importante papel na criação e implantação dos Centros de Pesquisas Educacionais alguns anos mais tarde.

Ao terminar o governo Mangabeira, Anísio Teixeira foi convidado pelo Ministro da Educação Ernesto Simões Filho para dirigir a CAPES - Comissão (o nome mudaria para Coordenação) de Aperfeiçoamento do Pessoal de Nível superior. Em 1952, foi convidado para dirigir o INEP - Instituto Nacional de Estudos Pedagógicos (hoje Instituto Nacional de Estudos e Pesquisas Educacionais). Anísio Teixeira permaneceu nos dois cargos até 1964.

\footnotetext{
${ }^{2}$ Maria Clara MARIANI, Educação e ciências sociais: o Instituto Nacional de Estudos e Pesquisas Educacionais. In: Universidades e instituições científicas no Rio de Janeiro, p.169.

${ }^{3}$ Ibidem. p. 170 .

${ }_{5}^{4}$ Clarice NUNES, Anísio Spínola Teixeira. In: Dicionário de educadores no Brasil, 1999. p. 56.

${ }^{5}$ Mariza CORRÊA, A revolução dos normalistas, Cadernos de Pesquisa, n. 66, p. 18.
} 


\section{O processo de criação do Centro Brasileiro e dos Centros Regionais de Pesquisas} Educacionais.

O Decreto n. 38.460 , de 28 de dezembro de 1955, instituiu o Centro Brasileiro de Pesquisas Educacionais, com sede no Rio de Janeiro, e os Centros Regionais de Recife, Salvador, Belo Horizonte, Porto Alegre e São Paulo. O Centro Regional paulista foi inaugurado em junho de 1956 e deveria atender aos Estados de São Paulo, Paraná, Mato Grosso e Goiás. Essas datas, contudo, referem-se ao momento de concretização de um complexo processo de criação dessas instituições que começou no início da década de 50. Ao fazer algumas considerações a respeito deste processo, Forestan Fernandes ${ }^{6}$ divide-o em duas fases: a primeira iniciando-se em 04 de julho de 1952 e terminando em 1954; e, a segunda acontecendo a partir de 1955.

Em 04 de julho de 1952, Anísio Teixeira tomou posse como diretor do INEP. Em seu discurso, coerente com a sua trajetória de atuação no campo educacional, ele defendeu a idéia de que o INEP deveria fornecer ao Ministério da Educação e Cultura a base de estudos e pesquisas necessárias à "reconstrução educacional brasileira":

"O Instituto Nacional de Estudos Pedagógicos tem de tentar uma tomada de consciência na marcha da expansão educacional brasileira, examinar o que foi feito e como foi feito, proceder a inquéritos esclarecedores e experimentar medir a eficiência ou ineficiência de nosso ensino"?

Neste discurso, além da necessidade de realização de inquéritos objetivos, defende-se a idéia de que os fatos apurados devem fornecer elementos que contribuam para a prática educacional, na medida em que possibilitam verificação do cumprimento dos objetivos educacionais estabelecidos. "É necessário levar o inquérito às práticas educacionais", dizia Anísio Teixeira.

Logo depois de sua posse na direção do INEP, Anísio Teixeira propôs a criação de duas campanhas: a CILEME (Campanha de Inquéritos e Levantamentos do Ensino Médio e Elementar) e a CALDEME (Campanha do Livro Didático e Manuais de Ensino), que pretendiam estudar o ensino elementar e médio, suas inter-relações com o ambiente social e publicar manuais que servissem como guias para os professores ${ }^{9}$. Em 1953, o Centro de

\footnotetext{
${ }^{6}$ Florestan FERNANDES, Educação e Sociedade no Brasil, p. 565-78.

${ }^{7}$ Anísio TEIXEIRA, Discurso de posse do Professor Anísio Teixeira no Instituto Nacional de Estudos

Pedagógicos, Revista Brasileira de Estudos Pedagógicos, vol. 17, n. 46, p. 76.

${ }^{8}$ Ibidem. p. 78.

${ }^{9}$ OS ESTUDOS e as pesquisas educacionais no Ministério da Educação e Cultura, Educação e Ciências Sociais, n. 01, p. $05-60$.
} 
Documentação Pedagógica foi criado para sistematizar os trabalhos desenvolvidos pelas duas campanhas e demais setores do INEP.

Em setembro de 1952, o Diretor do Departamento de Educação da UNESCO, William Beatty esteve no Brasil, com a finalidade de "sondar as possibilidades de ser instalado em nosso país um centro latino-americano de preparação de educadores rurais e especialistas em educação de base" ${ }^{\prime 10}$. Depois de visitar diversos centros de ensino agronômico, William Beatty concluiu que nenhum estava em condições de receber o organismo planejado. Anísio Teixeira propôs, então, a realização de "um grande survey sobre a situação educacional do país, feito por especialistas do Brasil e da UNESCO, que gerasse elementos sobre os quais fosse possível planejar, em todos os níveis e graus de ensino, medidas de longo alcance visando à reconstrução educacional do país" $"$.

Esta idéia foi evoluindo com a colaboração de:

$\begin{array}{lll}\text { Almir de Castro } & \text { Paulo Carneiro } & \text { Frederico Rangel } \\ \text { João Roberto Moreira } & \text { Delgado de Carvalho } & \text { Marvin Harris } \\ \text { Armando Hildebrand } & \text { Francisco Montojos } & \text { Adroaldo J. Aires } \\ \text { Charles Wagley } & \text { Jayme Abreu } & \text { Henry Laurentie } \\ \text { Carl Withers } & \text { R. Atcon } & \text { Otávio Martins }\end{array}$

Um ano mais tarde, em agosto de 1953, a idéia de realização de apenas um survey havia se desenvolvido para a criação de uma instituição permanente, que recebeu o nome provisório de "Centro de Altos Estudos Educacionais". Charles Wagley e Carl Withers prepararam um relatório com sugestões sobre a organização e as finalidades dessa instituição.

Em janeiro de 1954, William Carter (Chefe do UNESCO Exchange of Persons Programme) veio ao Brasil para acertar a vinda de técnicos estrangeiros. Nessa ocasião, Anísio Teixeira lhe apresentou uma primeira formulação dos objetivos e finalidades do futuro Centro, que serviria de base para o recrutamento dos membros da equipe a ser enviada ao país pela UNESCO. Os objetivos gerais do Centro seriam os seguintes:

"1. a pesquisa das condições culturais do Brasil em suas diversas regiões, das tendências de desenvolvimento e de regressão e das origens dessas condições e forças - visando a uma interpretação regional do país tão exata e tão dinâmica quanto possível. Essa pesquisa deveria permitir a formulação de uma política institucional, referente à educação, capaz de orientar o desenvolvimento desejável de cada região do país.

\footnotetext{
${ }^{10}$ Ibidem. p. 37.

${ }^{11}$ Ibidem, p. 37.
} 
2. a pesquisa das condições escolares do Brasil, em suas diversas regiões, por meio do levantamento dos seus recursos em administração, aparelhamento, professores, métodos e conteúdo de ensino, visando apurar até quanto a escola está satisfazendo as suas funções em uma sociedade em mudança para o tipo urbano e industrial de civilização democrática e até quanto está dificultando essa mudança, com a manutenção dos objetivos apenas alargados da sociedade em desaparecimento.

3. à luz a política institucional formulada pela pesquisa antropossocial e das verificações da pesquisa educacional: a) elaborar planos, recomendações e sugestões para a reconstrução educacional de cada região do país, no nível primário, rural e urbano, secundário e normal, superior e de educação de adultos; b) elaborar livros de texto de administração escolar, de construção de currículo, de psicologia educacional, de filosofia da educação, de medidas escolares, etc.

4. treinamento de administradores e especialistas em educação para lotar os Estados e os Centros Regionais de Estudos Pedagógicos e os próprios departamentos de educação das escolas de filosofia das universidades brasileiras" ${ }^{\prime 2}$.

No final de 1954, o sociólogo britânico Bertram Hutchinson chegou ao Brasil para cooperar na organização da nova instituição.

Em 1955, inicia-se a segunda fase de criação do Centro, com a elaboração de seus planos de organização. Em abril deste ano, Otto Klineberg (UNESCO) esteve no Rio de Janeiro e propôs um esquema com objetivos e sugestão de organização. Ele também sugeriu que se mudasse o nome da instituição de Centro de Altos Estudos Educacionais para Centro de Pesquisas Educacionais.

No documento elaborado por Otto Klineberg ${ }^{13}$ destaca-se a necessidade de adaptar a educação brasileira às necessidades do povo brasileiro e sua diversidade geográfica; a necessidade de se divulgar os resultados das pesquisas realizadas aos professores; de proporcionar maior contato entre estudiosos brasileiros e de outros países; de proporcionar melhor preparação dos educadores em ciências sociais; de aplicar as ciências sociais aos problemas educacionais; e, a necessidade de criação de um modelo de melhoramento do sistema educacional que poderia ser seguido em outros países.

O "Documento Klineberg" também ficou conhecido por sugerir, como objetivos do Centro, a realização de um "mapa cultural" e um "mapa educacional" brasileiros. O "mapa cultural" seria composto pelo "conhecimento completo da cultura brasileira contemporânea, no seu sentido mais amplo, incluindo a vida de família e criação de filhos; atividades econômicas e sociais, o uso do tempo de lazer, atitudes psicológicas, objetivos e ideais, com a

\footnotetext{
${ }^{12}$ Ibidem, p. 38-9 (grifos meus).

${ }^{13}$ Otto KLINEBERG, Centro Brasileiro de Pesquisas Educacionais, Revista Brasileira de Estudos Pedagógicos, v. 24, n. 59, p. 118-36. Observe-se que ao reproduzir este documento, a Revista faz uma pequena Introdução na
} 
devida atenção à herança religiosa e ética do povo"14. O "mapa educacional" deveria apresentar um "quadro completo e satisfatório do estado atual da educação brasileira, em todos os níveis e em todas as regiões" ${ }^{15}$. Esses mapas seriam interdependentes e deveriam ser usados em conjunto para que se fizessem as modificações necessárias na estrutura educacional, a fim de adaptá-la às necessidades culturais de cada região.

Charles Wagley, da Columbia University, chegou ao Brasil pouco depois da volta de Otto Klineberg à UNESCO. Como foi apresentado na parte anterior deste trabalho, Charles Wagley era um cientista "identificado com os problemas brasileiros e colaborador constante de Anísio Teixeira e de sua equipe da CAPES, na realização da idéia do Centro"16. Juntamente com João Roberto Moreira, este pesquisador, a partir de junho de 1955, começou a criação prática do Centro Brasileiro de Pesquisas Educacionais: instalação da sede, planejamento das primeiras pesquisas, recrutamento dos primeiros cientistas (Josildeth Gomes, Carlo Castaldi, José Bonifácio Rodrigues, Orlando F. de Melo, L. de Castro Faria e L. A. Costa Pinto), etc.

Ao mesmo tempo, em São Paulo, estavam em curso os preparativos do que viria a ser o Centro Regional de Pesquisas Educacionais de São Paulo (CRPE/SP). Em 19 de julho de 1955, foi assinado um acordo entre o MEC, o INEP e a Reitoria da Universidade de São Paulo, no qual o INEP entregou à Faculdade de Filosofia, Ciências e Letras da USP o prédio do "Instituto do Professor Primário", construído na Cidade Universitária, para que nele funcionasse o "Centro Regional de Aperfeiçoamento do Magistério". Este prédio fazia parte de um conjunto arquitetônico projetado pelo arquiteto Rocha Miranda que seria composto por cinco edifícios. O prédio construído possuía dois pavimentos, medindo duzentos metros de comprimento por trinta de largura.

Segundo o "Termo de Acordo"17, o Departamento de Sociologia e Antropologia da FFCL/USP elegeria um docente para assumir a direção do Centro, se responsabilizaria por sua manutenção, em articulação com o INEP, e utilizaria o prédio para os trabalhos de pesquisas e demais atividades relativas às finalidades do Centro. Os objetivos gerais deste Centro eram

qual apresenta o CBPE como um “centro nacional de aperfeiçoamento do magistério”, cuja organização já era planejada pelo INEP desde 1953, com a colaboração da UNESCO.

${ }^{14}$ Ibidem, p. 119.

15 Ibidem, p. 120.

${ }^{16}$ OS ESTUDOS e as pesquisas educacionais no Ministério da Educação e Cultura, Educação e Ciências Sociais, n. 01, p. 43.

${ }^{17}$ TERMO de Acordo celebrado ente o INEP, do Ministério da Educação e Cultura, e a Reitoria da USP, para a manutenção do Centro Regional de Aperfeiçoamento do Magistério de São Paulo, de 19 de julho de 1955.

Arquivo Histórico do INEP. 
exatamente aqueles citados acima, elaborados por Anísio Teixeira e apresentados à William Carter, em 1954.

Niuvenius Paoli, em sua tese de doutorado, aponta a "interessante relação entre a concepção do projeto do centro e a sua execução, no sentido de não se aguardar que o projeto e sua formalização estivessem totalmente prontos para então se tomar providências para a sua realização"18, ou seja, apesar de se fazer um acordo de cessão para o funcionamento do Centro Regional de Aperfeiçoamento do Magistério, tratava-se do que viria a ser o CRPE/SP.

“(...) a utilização de uma designação como 'Centro de Aperfeiçoamento do Magistério', muito provavelmente deve ter sido uma estratégia política, de um lado para tornar mais palatável as outras funções do centro; por outro lado, a origem dos recursos estava na rubrica 'Manutenção de um Centro Nacional e instalação de Centros Regionais, para aperfeiçoamento do magistério primário e normal'. Na medida em que as ações eram desenvolvidas no âmbito do INEP era necessário mantê-las dentro dos limites institucionais, e, ao que parece, Anísio Teixeira conseguia juntar uma perspectiva política com uma habilidade em lidar com meandros da estrutura administrativa, de uma tal maneira que conseguia desviar-se das pedras burocráticas sem perder o rumo"19. (...) "Na verdade, uma das dificuldades políticas enfrentadas nessa época era exatamente a de destinar recursos para a pesquisa em educação ao invés de aplicar essas verbas na própria rede escolar,"20.

Em 18 de agosto de 1955, reuniram-se no Rio de Janeiro, depois de uma sessão preparatória em São Paulo, Anísio Teixeira e um grupo de cientistas sociais e educadores com os seguintes objetivos: 1. Discutir o plano de trabalho de João Roberto Moreira e Charles Wagley e as propostas de Otto Klineberg; 2. Definir os objetivos e a organização do CBPE e dos Centros Regionais, especialmente o de São Paulo ${ }^{21}$. Compareceram à esta reunião:

$\begin{array}{lll}\text { Anísio Teixeira } & \text { Florestan Fernandes } & \text { L. de Castro Faria } \\ \text { Almeida Júnior } & \text { L. A. Costa Pinto } & \text { José Bonifácio Rodrigues } \\ \text { Charles Wagley } & \text { Fernando de Azevedo } & \text { Bertram Hutchinson } \\ \text { Jayme Abreu } & \text { João Roberto Moreira } & \text { Egon Schaden } \\ \text { Antônio Cândido } & \text { Mário de Brito } & \\ \text { Lourival Gomes Machado } & \text { Henri Laurentie } & \end{array}$

\footnotetext{
${ }^{18}$ Niuvenius Junqueira PAOLI, As relações entre Ciências Sociais e Educação nos anos 50/60 a partir das histórias intelectuais de quatro personagens (Josildeth Gomes Conserte, Aparecida Joly Gouveia, Juarez Brandão Lopes e Oracy Nogueira), p. 53.

${ }^{19}$ Ibidem, p. 54.

${ }^{20}$ Ibidem, p. 56.

${ }^{21}$ OS ESTUDOS e as pesquisas educacionais no Ministério da Educação e Cultura, Educação e Ciências Sociais, n. 01, p. 43.
} 
Florestan Fernandes fez uma exposição crítica a respeito dos documentos discutidos. Seu objetivo era impedir que o CBPE se tornasse um "instituto acadêmico de estudos, por ventura útil às ambições científicas de especialistas estrangeiros interessados em realizar pesquisas de psicologia, antropologia, sociologia ou pedagogia no Brasil”22 . De forma geral, o autor destaca a necessidade e a possibilidade de se estabelecer no CBPE: 1. Cooperação entre educadores e cientistas sociais; 2. Cooperação entre especialistas do Rio e de São Paulo; 3. Cooperação entre estrangeiros e brasileiros; 4. Utilização dos programas de atividades da CILEME, CALDEME e do Centro de Documentação Pedagógica do INEP, no CBPE, de forma orgânica.

Para Florestan Fernandes, "a criação de um centro de pesquisas, que pusesse a serviço do Ministério da Educação a investigação científica, racionalmente aproveitada para fins práticos, era algo que se fazia prementemente necessário" 23 .

Em dezembro de 1955, chegou ao Rio de Janeiro, Andrew Pearse, cientista social britânico, enviado pela UNESCO, para colaborar nas atividades do Centro.

\section{A organização formal do CBPE e dos Centros Regionais.}

O Centro Brasileiro e os Centros Regionais de Pesquisas Educacionais deveriam atender à necessidade de "dotar o INEP de meios adequados à pesquisa educacional em toda a extensão do território brasileiro, para o melhor cumprimento de seus objetivos fundamentais de estudo e aperfeiçoamento do magistério brasileiro, primário e normal"24. Seus objetivos, muito semelhantes àqueles elaborados por Anísio Teixeira, em 1954, eram:

"I - pesquisa das condições culturais e escolares e das tendências de desenvolvimento de cada região e da sociedade brasileira como um todo, para o efeito de conseguir-se a elaboração gradual de uma política educacional para o país;

II - elaboração de planos, recomendações e sugestões para a revisão e a reconstrução educacional do país - em cada região - nos níveis primário, médio, e superior e no setor de educação de adultos;

III - elaboração de livros de fontes e de textos, preparo de material de ensino, estudos especiais sobre administração escolar, currículos, psicologia educacional, medidas escolares, formação de mestres e sobre quaisquer outros temas que concorram para o aperfeiçoamento do magistério nacional;

\footnotetext{
${ }^{22}$ Essa importante crítica foi reproduzida parcialmente no artigo citado acima (p. 44-5) e publicada, na íntegra, no livro Educação e Sociedade no Brasil (Cap. 4: o Centro Brasileiro de Pesquisas Educacionais, p. 565-78).

${ }^{23}$ OS ESTUDOS e as pesquisas educacionais no Ministério da Educação e Cultura, Educação e Ciências Sociais, n. 01, p. 45.

${ }^{24}$ Trecho inicial do Decreto n. ${ }^{\circ} 38.460$, de 28 de dezembro de 1955, que institui o Centro Brasileiro e os Centros Regionais de Pesquisas Educacionais, publicado no Diário Oficial de 24 de janeiro de 1956 e reproduzido pela Revista Brasileira de Estudos Pedagógicos, vol. 25, n. 61, p. 151-3.
} 
IV - treinamento e aperfeiçoamento de administradores escolares, orientadores educacionais, especialistas de educação e professores de escolas normais e primárias, 25 .

Assinaram o Decreto o vice-presidente do Senado Federal, no exercício do cargo de Presidente da República, Nereu Ramos, e o Ministro da Educação e Cultura, Abgar Renault.

As seguintes diretrizes de trabalho foram traçadas para o cumprimento dos objetivos estabelecidos:

a) “A análise do processo de desenvolvimento que vem afetando a sociedade brasileira como um todo, embora com intensidade variável nas diferentes regiões do país, impõe-se como tarefa básica, que representará verdadeira tomada de consciência dos problemas emergentes desse processo.

b) Concebida a escola como fator de progresso ou de reajustamento, ou de influência que deve ser canalizada no sentido traçado pelo desenvolvimento do sistema social em causa, as diretrizes de uma política educacional exigem fundamentação, para a qual os estudiosos de educação e de ciências sociais podem e devem contribuir.

c) As relações entre a educação e a sociedade devem ser consideradas nos seus aspectos dinâmicos, e, portanto, o objetivo da análise é o próprio processo em desenvolvimento dentro de situações concretas globais, e não os seus produtos formais ou os elementos decorrentes.

d) A reestruturação do ensino brasileiro, para que a escola possa servir a todos como agência de transmissão do patrimônio cultural e da sua própria harmonização, deve constituir o alvo principal das atividades do Centro, encarando-se a educação como um dos fatores que devem ser utilizados, até onde for possível, no processo de aceleramento, correção ou equilíbrio do desenvolvimento da sociedade brasileira.

e) A pesquisa em ciências sociais, realizada dentro do Centro, deve subordinar-se, em princípio, aos interesses objetivos da ação educacional.

f) A pesquisa em ciências sociais deve ser explorada amplamente, para que seja possivel obter conhecimentos positivos sobre as condições de existência na sociedade brasileira e sobre o modo de integração e de funcionamento do sistema escolar dentro dela.

g) A pesquisa educacional dever ser explorada de maneira que permita o aproveitamento regular dos resultados da pesquisa em ciências sociais, sempre tendo em vista as possibilidades de ajustar o sistema educacional às condições de existência e às exigências de desenvolvimento econômico, social e cultural das diversas regiões do país.

h) Os resultados das pesquisas em ciências sociais e da pesquisa educacional servirão para elaborar os fundamentos da política educacional, ou de orientação para reformas específicas, ou programas restritos de alteração do sistema educacional.

i) O estudo da organização da escola, nos diversos níveis, se fará tendo em vista ajustá-la às descobertas da investigação científica e às necessidades do meio social ambiente." 26

\footnotetext{
${ }^{25}$ Art. $2 .^{\circ}$ do Decreto n. ${ }^{\circ} 38.460$, de 28 de dezembro de 1955 (grifos meus).

${ }^{26}$ OS ESTUDOS e as pesquisas educacionais no Ministério da Educação e Cultura, Educação e Ciências Sociais, n. 01, p. 51-2.
} 
O organograma básico do CBPE era o seguinte (com possibilidade alterações para casos regionais):

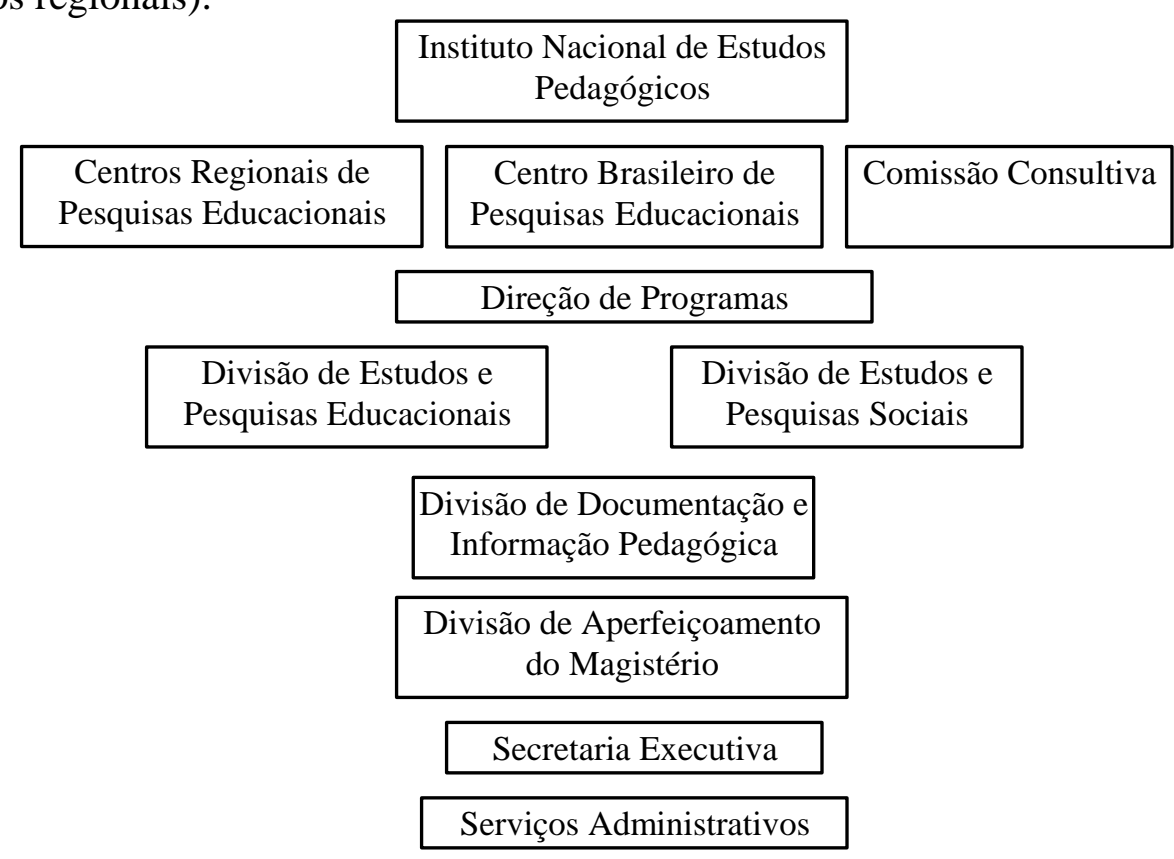

Cabia à Divisão de Estudos e Pesquisas Sociais (DEPS) a realização de estudos e pesquisas que conduzissem "ao conhecimento da cultura e da sociedade brasileira e de seu desenvolvimento, em conjunto e em cada região do país, a fim de permitir a compreensão mais ampla e profunda que for possível dos fatos educacionais em suas relações com a vida social, de acordo com o que foi estabelecido na definição de fins e objetivos do CBPE"27.

A Divisão de Estudos e Pesquisas Educacionais (DEPE) deveria levantar "um quadro completo satisfatório do estado atual da educação brasileira em todos os níveis e ramos, bem como em todas as regiões do país" 28 .

A Divisão de Aperfeiçoamento do Magistério (DAM) teria por objetivo, "além dos cursos baseados nos estudos e pesquisas realizados pelos Centros Regionais, projetos próprios destinados à formação e aperfeiçoamento de administradores escolares, especialistas em educação, professores de escola normal e professores em geral. (...)À DAM competirá ainda a organização e manutenção de escolas experimentais, destinadas a servir de campo experimental para os diversos cursos mencionados; realizar uma educação eficiente e adequada ao nível e necessidades dos alunos, e às condições e necessidades sociais; experimentar métodos e procedimentos de ensino primário; funcionar como laboratório para

\footnotetext{
${ }^{27}$ Ibidem, p. 54.

${ }^{28}$ Ibidem, p. 55.
} 
estudos e pesquisas sobre o escolar, programas de ensino, preparo do professor, métodos e recursos de educação e outros problemas correlatos" ${ }^{29}$.

A Comissão Consultiva era constituída pelos Diretores de Programas e por um ou dois representantes de cada um dos Centros Regionais, sob a presidência do Diretor do INEP. Cabia a essa Comissão, uma vez convocada pelo Diretor do INEP, discutir os planos dos trabalhos dos diferentes Centros Regionais e do CBPE, tendo em vista sua coordenação ${ }^{30}$. Além disso, uma cópia de todos os planos, projetos específicos, relatórios e quaisquer documentos que possibilitassem uma troca de informações entre o CBPE e os Centros Regionais deveria ser encaminhada à Divisão de Documentação e Informação Pedagógica do CBPE.

É importante lembrar que o CBPE não deveria ter qualquer função diretora sobre os demais Centros, sendo "um simples coordenador de trabalhos num mesmo plano de igualdade com os seus congêneres dos Estados" ${ }^{31}$.

Nos Centros Regionais deveria haver uma comissão consultiva ou equivalente para a discussão e aprovação dos planos próprios.

\section{O Centro Regional de Pesquisas Educacionais de São Paulo (CRPE/SP).}

O Centro Regional de Pesquisas Educacionais de São Paulo foi o primeiro Centro Regional a ser criado, em 22 de maio de 1956, através de um convênio, válido por cinco anos, celebrado entre o Ministério da Educação e Cultura e a Reitoria da Universidade de São Paulo.

Como o Termo de Acordo de julho de 1955 (visto acima) já havia entregue o prédio do Instituto do Professor Primário à Universidade de São Paulo para que nele funcionasse o Centro Regional de Aperfeiçoamento do Magistério, o novo convênio ${ }^{32}$, apenas confirmou essa entrega e garantiu que o INEP contribuiria para a manutenção do Centro com $20 \%$ da verba anual concedida, pelo Orçamento da República, para a manutenção do CBPE e dos Centros Regionais.

\footnotetext{
${ }^{29}$ Ibidem, p. 57.

${ }^{30}$ Ibidem, p. 54.

${ }^{31}$ 2. ${ }^{a}$ SESSÃO da Comissão Consultiva dos Centros de Pesquisas Educacionais, Educação e Ciências Sociais, n. 8 , p. 04.

${ }^{32}$ TERMO de acordo celebrado entre o Instituto Nacional de Estudos Pedagógicos, do Ministério da Educação e Cultura, e a Reitoria da Universidade de São Paulo, para a instalação e manutenção do Centro Regional de Pesquisas Educacionais de São Paulo, de 22 de maio de 1956, Arquivo CRPE - Centro de Memória/USP.
} 
A Universidade de São Paulo, por intermédio do Departamento de Sociologia e Antropologia da Faculdade de Filosofia, Ciências e Letras, comprometia-se a manter o Centro, cujo Diretor deveria ser escolhido entre os docentes daquele Departamento.

Anísio Teixeira convidou Fernando de Azevedo para dirigir o CRPE/SP, depois que Antônio Cândido e Florestan Fernandes recusaram o convite ${ }^{33}$. Anísio Teixeira teria hesitado em fazer esse convite por considerar Fernando de Azevedo uma figura de grande destaque no cenário político nacional, que não se interessaria pela direção de um centro de pesquisas. Fernando de Azevedo era membro de Departamento de Sociologia e Antropologia da USP, além de ter sido um dos fundadores da USP e Secretário de Educação em várias oportunidades. O convite, entretanto, foi aceito por Fernando de Azevedo, que declarou ter sido convencido pelo argumento apresentado por Anísio Teixeira de que o Centro Regional somente seria criado em São Paulo se ele "concordasse em assumir as responsabilidades de sua instalação, organização e direção",34.

Mesmo não aceitando o convite para a direção do Centro, Antônio Cândido e Florestan Fernandes participaram do seu primeiro Conselho de Administração. O Conselho de Administração tinha a função de assistir ao Diretor Geral, reunindo-se mensalmente, em caráter ordinário. Seus membros tinham mandato de três anos e eram escolhidos da seguinte forma: dois eram eleitos pelo Departamento de Sociologia e Antropologia da FFCL/USP (Egon Schaden e Forestan Fernandes); dois eram eleitos pelo Departamento de Pedagogia (José Querino Ribeiro e Laerte Ramos de Carvalho); e, dois eram escolhidos diretamente pelo Diretor do Centro (Antônio Cândido e Milton da Silva Rodrigues). Milton da Silva Rodrigues foi eleito, no primeiro Conselho de Administração, como vice-presidente para suprir eventuais ausências do Diretor Geral $^{35}$.

O "Regulamento ou Plano de Organização do Centro Regional de Pesquisas Educacionais de São Paulo"36 apresenta como fins e objetivos do Centro paulista, os mesmos do Centro Brasileiro de Pesquisas Educacionais, apenas substituindo as expressões referentes ao País como um todo, por expressões referentes à região específica a que servia (São Paulo,

\footnotetext{
${ }^{33}$ Florestan FERNANDES, Florestan Fernandes, p. 36.

${ }^{34}$ Fernando de AZEVEDO, História de minha vida, p.154.

${ }^{35}$ Fernando de AZEVEDO, Carta de Fernando de Azevedo à Anísio Teixeira, de 24 de janeiro de 1957. Relatório de Atividades do CRPE/SP-1956, Arquivo Histórico do INEP, p. 05.

${ }^{36}$ CENTRO REGIONAL DE PESQUISAS EDUCACIONAIS DE SÃO PAULO, Plano de Organização do Centro Regional de Pesquisas Educacionais de São Paulo (com instruções para o serviço), Arquivo CRPE Centro de Memória/USP.
} 
Paraná, Mato Grosso e Goiás). Para atingir os objetivos estabelecidos, o Centro propunha-se a:

1. "empreender levantamentos, inquéritos e pesquisas educacionais e sociais, de interesse para a educação, que com seus próprios grupos de pesquisadores quer em colaboração com instituições públicas ou particulares;

2. financiar pesquisas no plano educacional e social, propostas por especialistas capazes e idôneos, e segundo projetos aprovados pela Direção do Centro;

3. promover experiências e demonstrações práticas de novas técnicas de ensino, para lhes verificar a eficácia e os resultados, em suas escolas experimentais;

4. contribuir para completar, aperfeiçoar e especializar a instrução profissional dos diplomados por escolas normais, facilitando-lhes a especialização em setores em que se torne necessária;

5. realizar estudos sobre planos de reforma, propostos ou em andamento, de iniciativa dos poderes públicos, e promover planejamentos de reconstrução educacional, tendo em vista as conclusões de pesquisas realizadas pelos Centros existentes no país;

6. auxiliar e esclarecer, pelos seus órgãos de informação e relações públicas, os professores, diretores ou inspetores de escolas, sobre os problemas de educação, estruturais e metodológicos, e de administração escolar, quer sistematicamente através de suas publicações, quer atendendo a pedidos e consultas;

7. comunicar os trabalhos científicos, de pesquisa e experimentação, às sociedades e aos congressos de educação e de ciências sociais e às instituições congêneres, em permuta de comunicações, a fim de se manter ao corrente de progressos feitos, no país e no estrangeiros, nesse domínio de estudos e atividades científicas" ${ }^{\text {37. }}$.

Este Regulamento ou Plano de Organização não foi estabelecido logo no início das atividades do Centro. Conforme carta de Fernando de Azevedo à Anísio Teixeira, de 24 de janeiro de 1957, o Regulamento somente seria submetido à apreciação do Conselho de Administração em abril ou maio desse ano, uma vez que o Diretor do CRPE/SP pretendia criar os serviços e colocá-los em funcionamento, para depois estabelecer as normas que fossem julgadas mais convenientes ao seu andamento.

Inicialmente foram organizados os serviços administrativos indispensáveis e as duas divisões de pesquisas, a Divisão de Estudos e Pesquisas Educacionais (DEPE), dirigida por Joel Martins, e a Divisão de Estudos e Pesquisas Sociais (DEPS), com Renato Jardim Moreira.

A partir da necessidade de organização dos Cursos de Especialistas em Educação para a América Latina, realizados em parceria com a UNESCO, a Divisão de Aperfeiçoamento do Magistério (DAM) foi criada. Em 1957, Joel Martins passou a ser o diretor da DAM e Dante

\footnotetext{
${ }^{37}$ Ibidem, p. 02-3.
} 
Moreira Leite foi convidado para a direção da $\mathrm{DEPE}^{38}$. Com a criação da DAM, começaram a ser organizados o Serviço de Recursos Audiovisuais (inicialmente sob a responsabilidade de Genésio Flores) e a Escola Experimental (com Jorge Nagle). A Seção de Publicações, responsável pela publicação da revista Pesquisa e Planejamento, era chefiada por Eugênio César Bertoncini.

Com a implantação das Divisões de Pesquisas e de Aperfeiçoamento do Magistério, começaram a ser planejados os cursos e as pesquisas que seriam desenvolvidos no Centro. Os próximos capítulos deste trabalho apresentarão as principais características de todos os cursos e pesquisas que se iniciaram no Centro Regional paulista, de 1956 a 1961.

Em agosto de 1959, expirou o mandato dos membros do Conselho de Administração. O novo Conselho, constituído para o triênio 1959-1962, era formado por Egon Schaden e Ruy Galvão de Andrada Coelho (eleitos pelo Departamento de Sociologia e Antropologia da FFCL/USP), Laerte Ramos de Carvalho e José Querino Ribeiro (Seção de Pedagogia), Milton da Silva Rodrigues e Eurípedes Simões de Paula (FFCL/USP, escolhidos pelo diretor do Centro $)^{39}$.

Em 08 de outubro de 1959, Joel Martins afasta-se do cargo de Diretor da Divisão de Aperfeiçoamento do Magistério, sendo substituído por Heládio César Gonçalves Antunha. Em maio de 1960, Renato Jardim Moreira sai do Centro e da direção da Divisão de Estudos e Pesquisas Sociais. Esse cargo seria assumido por Haydée Maria Roveratti. Dante Moreira Leite também afasta-se do Centro e Maria do Carmo Guedes passa a responder pela Divisão de Estudos e Pesquisas Educacionais. Em 1961, o Serviço de Estatística é criado e as Classes Experimentais e o Serviço de Recursos Audiovisuais desligam-se da Divisão de Aperfeiçoamento do Magistério, ganhando maior autonomia.

Com essas alterações, em 1961, os responsáveis pelas Divisões passaram a ser:

\begin{tabular}{|l|l|}
\hline Divisão de Estudos e Pesquisas Educacionais & Maria do Carmo Guedes \\
\hline Divisão de Estudos e Pesquisas Sociais & Haydée Maria Roveratti \\
\hline Serviço de Estatística & Lybia de Mattos Bruno \\
\hline Divisão de Aperfeiçoamento do Magistério & Heládio César Gonçalves Antunha \\
\hline Classes Experimentais & Sylvia Alves \\
\hline Serviço de Recursos Audiovisuais & Horace C. Hartsell (Univ. Michigan) \\
\hline Seção de Publicações & Dirvan Silveira Lima Teixeira \\
\hline
\end{tabular}

${ }^{38}$ DIVISÃO DE APERFEIÇOAMENTO DO MAGISTÉRIO, Relatório de Atividades do CRPE/SP-1957, Arquivo Histórico do INEP, p. 46.

${ }^{39}$ SECRETARIA, Relatório de Atividades do CRPE/SP - 1959, Arquivo Histórico do INEP, p. 03. 
Fonte: Relatório de Atividades do CRPE/SP - 1961, Arquivo Histórico do INEP.

Na primeira reunião do Conselho de Administração de 1961, realizada no dia 4 de fevereiro, Fernando de Azevedo comunicou seu pedido de demissão, feito em 30 de janeiro de 1961 ao Diretor do INEP, Anísio Teixeira. Fernando de Azevedo solicitou ao Conselho que indicasse o nome de um de seus membros para substituí-lo a partir da data em que fosse aceita sua renúncia até a designação de um novo diretor para o Centro. Seu pedido de demissão somente foi aceito em 22 de maio de 1961, quando Milton da Silva Rodrigues assumiu a direção do CRPE/SP.

O novo Diretor convocou para $1 .^{\circ}$ de julho de 1961 uma reunião com os membros do Conselho de Administração para que se opinasse sobre o novo convênio a ser firmado entre o INEP e a USP para manutenção do Centro, uma vez que o convênio celebrado em 22 de maio de 1956 estava expirando. Nesta reunião o projeto de novo convênio foi apreciado e decidiuse que o Conselho de Administração deveria ser substituído por um Conselho Deliberativo.

O novo Termo de Acordo $^{40}$, assinado em 31 de agosto de 1961, manteve o convênio entre a USP e o INEP para dar continuidade às atividades do CRPE/SP por mais cinco anos.

Em 14 de setembro de 1961, foi realizada a eleição para escolher os nomes do futuro Diretor e membros do Conselho Deliberativo. O resultado da eleição foi encaminhado ao Reitor da Universidade e submetido à aprovação do diretor do INEP. Através destes atos, Laerte Ramos de Carvalho, Professor de História e Filosofia da Educação da FFCL/USP, foi designado para exercer as funções de Diretor do CRPE/SP, tomando posse em 13 de outubro daquele ano.

Em 11 de novembro, os seguintes membros Conselho Deliberativo assumiram suas funções: Arrigo Leonardo Angelini (Professor Catedrático de Psicologia Educacional), Maria José Garcia Werebe (Livre Docente da Cadeira de Administração Escolar e Educação Comparada), Octávio Ianni (Assistente Doutor da Cadeira de Sociologia I), Samuel Pfromm Netto (Assistente da Cadeira de Psicologia Educacional) e Fernando Henrique Cardoso (Assistente Doutor da Cadeira de Sociologia I). Octávio Ianni foi eleito o vice-diretor do Centro ${ }^{41}$.

\footnotetext{
${ }^{40}$ TERMO de Acordo celebrado entre o Instituto Nacional de Estudos Pedagógicos, do Ministério da Educação e Cultura, e a Reitoria da Universidade de São Paulo, aprovado pelo senhor Ministro da Educação e Cultura, para a Manutenção do Centro Regional de Pesquisas Educacionais de São Paulo, de 31 de agosto de 1961, Pesquisa e Planejamento, n. 5, p. 221-3.

${ }^{41}$ DIRETORIA, Relatório de atividades do CRPE/SP - 1961, Arquivo Histórico do INEP, p. 04-5.
} 
Com a posse do Diretor e do Conselho Deliberativo recém eleitos iniciava-se um novo período administrativo no Centro Regional de Pesquisas Educacionais de São Paulo. 


\section{Capítulo 2 - Cursos e Seminários.}

“(...) o professor e o diretor da escola seriam instruídos de que eles sempre se poderiam dirigir ao Centro para estudar problemas que lhes tivessem surgido e que não tivessem capacidade de resolver. Deste modo, não seriam apenas coletores de fatos mas pessoas que estariam refletindo sobre esses fatos e sentindo os problemas que eles suscitavam. E, assim, estariam fazendo parte do grande corpo de pesquisadores educacionais em que se deve transformar toda a profissão do magistério",

Este trecho de uma carta escrita por Anísio Teixeira a Fernando de Azevedo, em 24 de outubro de 1956 - momento de implantação do Centro e definição de suas atividades - é uma demonstração da sua compreensão a respeito do papel que o Centro Regional de Pesquisas Educacionais de São Paulo deveria desempenhar junto ao magistério.

Os cursos que aconteceram no CRPE/SP, de 1956 a 1961, deveriam incentivar seus participantes a realizar uma reflexão conjunta com os professores e pesquisadores do Centro a respeito dos problemas enfrentados pela educação brasileira.

Para cada curso ou seminário são apresentadas, na medida em que essas informações estavam disponíveis, o período em que foi ministrado, o número de alunos, sua procedência, os objetivos do curso, a justificativa de sua realização, os professores participantes, o coordenador do curso ou a Divisão responsável por sua realização, o órgão que promoveu ou financiou o curso e os resultados obtidos.

\section{I Seminário para Professores Primários.}

Este foi o primeiro seminário promovido pelo CRPE/SP. Iniciou-se em 07 de janeiro de 1957 e terminou em 04 de fevereiro do mesmo ano. O Seminário destinava-se aos professores primários dos Estados que eram atendidos pelo CRPE/SP - São Paulo, Paraná, Mato Grosso e Goiás. Foram oferecidas 100 vagas e o Seminário contou com a participação de 94 inscritos.

Joel Martins, diretor da Divisão de Estudos e Pesquisas Educacionais, foi o coordenador do Seminário e relator das atividades desenvolvidas. Os objetivos do Seminário, segundo o seu relator, visavam o crescimento do professor no exercício de suas funções, mais do que a sua formação profissional, e eram:

\footnotetext{
${ }^{1}$ Trecho de carta de Anísio TEIXEIRA a Fernando de Azevedo, de 24 de outubro de 1956, Arquivo Fernando de Azevedo - IEB/USP (grifos do autor). Esta carta está reproduzida integralmente no Anexo C.
} 
1. “Buscar os melhores professores primários, dentro da região servida pelo Centro Paraná, Mato Grosso, Goiás e São Paulo - e trabalhar com eles naqueles problemas considerados, pelos próprios professores, como sendo os mais importantes e aqueles onde, em geral são encontradas as maiores dificuldades.

2. Habilitar o professor a encontrar a melhor solução para aqueles problemas que venham enfrentar, pesquisando e lutando para acertar, mais do que satisfazendo-se com um receituário simples e apriorístico.

3. Despertar em cada professor a consciência da pesquisa e a inquietação científica necessária a todo professor.

4. Dar ao professor elementos para observar os seus alunos considerando-os como unidades distintas para aprender.

5. Possibilitar ao professor, através de um curso de conferências sobre assuntos de sociologia, antropologia, filosofia da educação e pedagogia, a redefinição ou ampliação dos conceitos sobre a educação e seus processos",2.

Além desses objetivos, o Seminário serviria para que o CRPE/SP obtivesse informações, por meio do contato com os participantes, que contribuíssem para a elaboração de estudos que levassem ao aperfeiçoamento dos ensinos normal e primário e, também, para preparar os professores para cooperar nas pesquisas desenvolvidas pelo Centro ${ }^{3}$.

\subsection{Professores e Cursos.}

Os seguintes professores e cursos fizeram parte deste Seminário:

\begin{tabular}{|l|l|}
\hline Curso & Professor \\
\hline Medidas em Educação, Sociologia e Psicologia & Prof. Carlos Prosperi \\
\hline $\begin{array}{l}\text { Técnica de Pesquisa em Educação e Ciências } \\
\text { Sociais }\end{array}$ & Prof. Álvaro Marchi \\
\hline Sociologia & Prof. Fernando Henrique Cardoso \\
\hline Técnica de Alfabetização & Prof ${ }^{a}$. Maria Aparecida Cintra \\
\hline Psicologia da Leitura & Prof $^{\text {}}$. Maria Apparecida Bortoletto \\
\hline Técnica de Ensino da Matemática & Prof $^{a}$. Dinah de Mattos Pimenta \\
\hline Psicologia da Aritmética & Prof $^{a}$. Haydée Pereira Bueno \\
\hline
\end{tabular}

Fonte: Relatório de atividades do CRPE/SP relativo ao período de junho de 1956 a agosto de 1960, Arquivo Histórico do INEP.

Dinah de Mattos Pimenta e Haydée Pereira Bueno fizeram um relatório conjunto sobre o Ensino de Matemática, no qual apresentavam como objetivos dos cursos "dar aos professores-alunos moderna orientação metodológica e proporcionar-lhes oportunidade de estudo e discussão dos processos mais eficientes para o ensino da matéria”"

\footnotetext{
2 Joel MARTINS, Relatório do I Seminário, Pesquisa e Planejamento, n. 1, p. 87.

${ }^{3}$ DIVISÕES DE ESTUDOS E PESQUISAS EDUCACIONAIS E DE ESTUDOS E PESQUISAS SOCIAIS, Cursos de aperfeiçoamento do magistério, Relatório de Atividades do CRPE/SP - 1956, Arquivo Histórico do INEP, p. 05.

${ }^{4}$ Dinah de Mattos PIMENTA e Haydée Pereira BUENO, Relatório do Curso de Matemática, Pesquisa e

Planejamento, n. 1, p. 93.
} 
As professoras relataram que consideraram os conhecimentos dos participantes dos cursos muito deficiente. Entretanto, através de um questionário, levantou-se a informação de que $81,8 \%$ dos alunos pretendiam aprender novas técnicas e métodos que lhes possibilitassem mais alto nível qualitativo e quantitativo de trabalho.

As professoras Maria Apparecida Bortoletto e Maria Aparecida Rodrigues Cintra também apresentaram um relatório sobre o curso de Psicologia da Leitura, cujo objetivo era “desenvolver conhecimentos capazes de orientar o professor na solução de problemas que mais comumente se apresentam na sua vida profissional"5. Para as responsáveis pelo curso, o seu grande problema era a falta de homogeneidade das turmas e sugeriram a adoção de critérios de seleção dos candidatos para solucioná-lo.

Os demais professores não divulgaram relatórios de seus cursos em quaisquer das fontes consultadas.

\subsection{Conferências.}

Além dos cursos acima apresentados, os participantes do I Seminário para Professores Primários também assistiram aos seguintes discursos e conferências:

\begin{tabular}{|l|l|l|}
\hline Data & Autor & Conferência \\
\hline $07 / 01$ & Fernando de Azevedo & "Luz nova sobre os caminhos" \\
\hline $12 / 01$ & Wilson Martins & "O novo Emílio" \\
\hline $19 / 01$ & Antônio Cândido & $\begin{array}{l}\text { "As diferenças entre o campo e a cidade e o seu } \\
\text { significado para a educação" }\end{array}$ \\
\hline $26 / 01$ & Egon Schaden & "Sobre a origem e a evolução do homem" \\
\hline $02 / 02$ & $\begin{array}{l}\text { Laerte Ramos de } \\
\text { Carvalho }\end{array}$ & "Sobre temas de Filosofia e História da Educação" \\
\hline $04 / 02$ & Anísio Teixeira & "Ciência e arte de educar" \\
\hline
\end{tabular}

Fonte: Relatório de atividades do CRPE/SP relativo ao período de junho de 1956 a agosto de 1960, Arquivo Histórico do INEP.

A revista Pesquisa e Planejamento publicou duas conferências que fizeram parte do Seminário e os discursos de abertura e encerramento.

A conferência de Wilson Martins tinha como tema as contribuições das Ciências Sociais à Educação. Segundo Wilson Martins, "de tudo o que a Educação pode esperar das Ciências Sociais, os benefícios mais fecundos serão representados pela abertura dos horizontes mentais dos professores. Para que a escola seja social, é preciso que o professor pense e sinta socialmente"

\footnotetext{
${ }^{5}$ Maria Aparecida BORTOLETTO e Maria A. Rodrigues CINTRA, Relatório do Curso de Psicologia da Leitura, Pesquisa e Planejamento, n. 1, p. 99.

${ }^{6}$ Wilson MARTINS, O novo Emílio - o que a educação pode esperar das ciências sociais, Pesquisa e

Planejamento, n. 1, p. 50.
} 
A conferência de Antônio Cândido focalizava as contradições da sociedade, principalmente em relação às diferenças entre o campo e a cidade, e indicava que cabia ao processo educacional a superação dessas desarmonias, sem contudo ser capaz de anula-las, visto que "a contradição é o dado imediato de todo processo vivo",

O pronunciamento de Anísio Teixeira tinha como tema central a criação do CRPE e seus objetivos. Destacava que o Centro colaboraria para a elaboração de uma nova política educacional para o país, fundada em critérios científicos e contando com a colaboração de educadores e cientistas sociais. Ao tratar, especificamente, do Seminário, Anísio Teixeira afirmou que este tinha sido "um primeiro contato entre os professores e mestres que trabalham nas classes e os que trabalham no Centro" ${ }^{\text {. }}$. O sentido dessa aproximação seria associar o professor primário à pesquisa educacional. Para Anísio Teixeira, "todo o trabalho do Centro visa, em última análise, tornar mais rica, mais lúcida e mais eficaz a ação educativa”9.

Fernando de Azevedo, em seus discursos, também tratou da função que o Seminário deveria desempenhar. Na oração proferida na sessão de abertura do Seminário, caracteriza-o como sendo uma "ponte de ligação" entre o CRPE/SP e as escolas, através dos professores participantes ${ }^{10}$. Em sua oração de encerramento, Fernando de Azevedo, dizia que era através desses professores que se difundiria pelas escolas o "fermento da renovação", ou seja, "o gosto da observação e análise", "o espírito crítico e experimental" e "a revisão de métodos e resultados práticos" que tornariam os professores "cada vez mais capazes de repensar suas idéias e de resolver com justeza os problemas que diante deles suscitará a vida profissional"11.

\section{Os Cursos de Especialistas em Educação para a América Latina.}

Os Cursos de Especialistas em Educação foram realizados, a partir de 1958, durante nove anos. Eles podem ser considerados, por sua estrutura de funcionamento, seus objetivos e a frequência com que se realizaram, como sendo os cursos de maior prestígio promovidos pelo CRPE/SP.

\subsection{Antecedentes.}

A UNESCO (Organização das Nações Unidas para a Educação, Ciência e Cultura) estabeleceu, em 1956, como sendo o seu Projeto Maior n. ${ }^{\circ}$ 1, a generalização e melhoria do

\footnotetext{
${ }^{7}$ Antonio CANDIDO, As diferenças entre o campo e a cidade e o seu significado para a educação, Pesquisa e Planejamento, n. 1, p. 53.

${ }^{8}$ Anísio TEIXEIRA, Ciência e Arte de Educar, Pesquisa e Planejamento, n. 1, p. 84.

${ }^{9}$ Ibidem, p. 84.

${ }^{10}$ Fernando de AZEVEDO, Luz nova sobre caminhos, Pesquisa e Planejamento, n. 1, p. 13.
} 
ensino primário e a formação de professores e especialistas em educação na América Latina. Esse Projeto foi apresentado durante a Conferência Regional sobre Educação Primária Gratuita e Obrigatória na América Latina e na Segunda Reunião Interamericana de Ministros da Educação, realizadas em Lima, no Peru.

O coordenador do projeto foi o Dr. Oscar Vera, da UNESCO, e a sua execução era prevista para um período de 10 anos, a partir de 1957.

Esse projeto visava a erradicação do analfabetismo no continente americano através de um sistema de educação primária universal, gratuita e obrigatória para todas as crianças, em todos os países. Sua base ideológica encontra-se na carta da UNESCO redigida após a 2. a Guerra Mundial, onde os Estados-Membros afirmam, de acordo com a Declaração Universal dos Direitos do Homem, sua crença em "completas e iguais oportunidades de educação para todos e pedem à Organização dar novo impulso à educação popular e à disseminação da cultura" ${ }^{\prime 2}$.

Segundo a revista Pesquisa e Planejamento, "o Governo Brasileiro, em agosto de 1956, aprovou a execução do Projeto Maior (Ofícios 855 e 910 do Ministério da Educação e Cultura), oferecendo, quando da resposta ao questionários da UNESCO, sua participação na realização de um Curso de Aperfeiçoamento, em nível universitário, de Especialistas em Educação para a América Latina, pelo CRPE de São Paulo, sob o patrocínio da Universidade de São Paulo, e em cooperação com o Ministério das Relações Exteriores e o Instituto Nacional de Estudos Pedagógicos, do Ministério da Educação e Cultura"13.

Em 11 de setembro de 1957, o Diretor Geral da UNESCO aprovou a realização dos Cursos para Especialistas em Educação, no Chile e em São Paulo. “As Universidades de São Paulo e Santiago do Chile, associadas, devotar-se-ão à tarefa de treinar especialistas de educação, nas várias áreas carentes, para o planejamento e o desenvolvimento integral da educação. Desta maneira, o Projeto Principal visa a formar tanto trabalhadores do campo de educação como bons administradores educacionais" ${ }^{\text {14 }}$.

\subsection{Organização geral dos Cursos.}

Os Cursos de Especialistas em Educação teriam sempre a duração de um ano letivo, com 36 semanas de trabalho efetivo.

\footnotetext{
${ }^{11}$ Fernando de AZEVEDO, Verdade, vida e chama, Pesquisa e Planejamento, n. 1, p. 104-5.

${ }^{12}$ Malcolm S. ADISESHIAH, A UNESCO e a luta contra o analfabetismo, Pesquisa e Planejamento, n. 2 , p. 59.

${ }^{13}$ PROJETO Maior n. $^{\circ} 1$ da UNESCO, Pesquisa e Planejamento, n. 2, p. 245.

${ }^{14}$ Malcolm S. ADISESHIAH, A UNESCO e a luta contra o analfabetismo, Pesquisa e Planejamento, n. 2 , p. 63.
} 
A UNESCO manteria dois professores estrangeiros nos cursos e concederia bolsas de aperfeiçoamento aos educadores selecionados para participar (geralmente havia 30 bolsas, 20 destinadas à participantes brasileiros e 10 para estrangeiros). Esses participantes deveriam ser “educadores de primeira plana e de grande experiência dentre professores de Escola Normal, administradores ou inspetores de ensino primário, estatísticos e outros especialistas em Educação"15.

O objetivo dos Cursos era o aperfeiçoamento dos educadores participantes nos campos de "Formação e Aperfeiçoamento do Magistério", "Planejamento, Organização e Administração Escolar" e "Supervisão e Desenvolvimento de Currículo".

O coordenador dos trabalhos do Curso seria sempre o Diretor da Divisão de Aperfeiçoamento do Magistério do CRPE/SP e os professores brasileiros e seus assistentes deveriam ser contratados, sempre que possível, entre os professores e assistentes da Faculdade de Filosofia, Ciências e Letras da Universidade de São Paulo.

De modo geral, os Cursos de Especialistas em Educação para a América Latina buscavam atingir os seguintes pontos ${ }^{16}$ :

1. Compreensão dos fundamentos da filosofia moderna de educação.

2. Compreensão da importância dos problemas educacionais.

3. Compreensão de como os educandos se desenvolvem e aprendem e como esse conhecimento deve funcionar no planejamento da educação.

4. Compreensão da importância da comunidade no planejamento e manutenção do sistema educacional.

5. Conhecimento da variedade de material, métodos e facilidades à disposição da tarefa educativa.

6. Conhecimento dos problemas educacionais da América Latina.

7. Desenvolvimento da consciência e da responsabilidade na solução dos problemas educacionais de cada país.

\subsection{CEEAL (I Curso de Especialistas em Educação para a América Latina).}

O primeiro CEEAL aconteceu de 17 de março a 13 de dezembro de 1958 e contou com 27 participantes. A origem dos participantes foi a seguinte:

\begin{tabular}{|l|l|l|l|}
\hline Estrangeiros & $\mathbf{N}^{\mathbf{0}}$ & Brasileiros & $\mathbf{N}^{\mathbf{0}}$ \\
\hline Argentina & 1 & Espírito Santo & 1 \\
\hline
\end{tabular}

\footnotetext{
${ }^{15}$ PROJETO Maior n. $^{\circ} 1$ da UNESCO, Pesquisa e Planejamento, n. 2, p. 247.

${ }^{16}$ DIVISÃO DE APERFEIÇOAMENTO DO MAGISTÉRIO, Curso de Especialistas em Educação para a América Latina, Relatório de Atividades CRPE/SP - 1958, Arquivo Histórico do INEP, p. 26-7.
} 


\begin{tabular}{|l|l|l|l|}
\hline Bolívia & 1 & Amazonas & 1 \\
\hline Chile & 2 & Paraná & 1 \\
\hline Colômbia & 1 & Minas Gerais & 3 \\
\hline Equador & 1 & Paraíba & 1 \\
\hline Panamá & 1 & Rio G. do Sul & 2 \\
\hline Peru & 1 & Rio de Janeiro & 1 \\
\hline Uruguai & 1 & São Paulo & 6 \\
\hline Venezuela & 2 & & \\
\hline TOTAL & $\mathbf{1 1}$ & TOTAL & $\mathbf{1 6}$ \\
\hline TOTAL GERAL & \multicolumn{3}{|l|}{$\mathbf{2 7}$} \\
\hline
\end{tabular}

Fonte: Relatório de atividades do CRPE/SP relativo ao período de junho de 1956 a agosto de 1960, Arquivo Histórico do INEP.

O coordenador do Curso foi o Diretor da Divisão de Aperfeiçoamento do Magistério, Joel Martins.

Os professores e as áreas de estudo que formaram este curso foram:

\begin{tabular}{|c|c|c|}
\hline Professores/UNESCO & Formação & Cursos oferecidos \\
\hline Dr. ${ }^{a}$ Hilda Taba & $\begin{array}{l}\text { - Ph.D.Columbia University } \\
\text { - Prof }{ }^{a} \text {. do San Francisco } \\
\text { State College }\end{array}$ & $\begin{array}{llll} & \text { Fundamentos } & \text { sociais } & \text { e } \\
\text { filosóficos da Educação. } & \\
-\quad \text { Técnica de } & \text { Construção } & \text { de } \\
\text { Currículo. } & & \\
-\quad \text { Processos de } & \text { Trabalho em } \\
\text { Grupo. } & & & \\
\end{array}$ \\
\hline Prof. Jack Robinson & $\begin{array}{l}\text {-A.B. University of Los } \\
\text { Angeles } \\
\text {-Consultant in Elementary } \\
\text { Education, Office of County } \\
\text { Superintendent of Schools, } \\
\text { Santa Barbara, Califórnia. }\end{array}$ & $\begin{array}{l}\text { Supervisão e Administração } \\
\text { Escolar. }\end{array}$ \\
\hline
\end{tabular}

\begin{tabular}{|l|l|l|}
\hline Professores/CRPE-SP & Formação & Cursos oferecidos \\
\hline Prof. Luiz Contier & $\begin{array}{l}\text { Diretor do I. E. Alberto } \\
\text { Comte }\end{array}$ & $\begin{array}{l}\text { - Organização de Escolas Secundárias } \\
\text { - Formação de Professores }\end{array}$ \\
\hline Prof. Heládio Antunha & $\begin{array}{l}\text { Licenciado em Filosofia } \\
\text { (FFCL/USP) }\end{array}$ & $\begin{array}{l}\text { Problemas Educacionais Latino } \\
\text { Americanos }\end{array}$ \\
\hline Prof. Jorge Nagle & $\begin{array}{l}\text { Licenciado em Pedagogia } \\
\text { (FFCL/USP) }\end{array}$ & $\begin{array}{l}\text { Organização de Escolas Primárias no } \\
\text { Brasil }\end{array}$ \\
\hline $\begin{array}{l}\text { Prof. José Mário Pires } \\
\text { Azanha }\end{array}$ & $\begin{array}{l}\text { Licenciado em Pedagogia } \\
\text { (FFCL/USP) }\end{array}$ & Pesquisa em Educação \\
\hline $\begin{array}{l}\text { Profa } \text { M. Aparecida T. } \\
\text { Garcia (assistente) }\end{array}$ & $\begin{array}{l}\text { Licenciada em Pedagogia } \\
\text { (FFCL/USP) }\end{array}$ & Estatística e Pesquisa em Educação \\
\hline $\begin{array}{l}\text { Prof } \text {. Lourdes Britto } \\
\text { (assistente) }\end{array}$ & $\begin{array}{l}\text { Licenciada em Pedagogia } \\
\text { (FFCL/USP) }\end{array}$ & Estatística e Pesquisa em Educação \\
\hline
\end{tabular}

Fonte: Relatório de atividades do CRPE/SP relativo ao período de junho de 1956 a agosto de 1960, Arquivo Histórico do INEP. 
Além desses cursos, foram oferecidos os seguintes ciclos de conferências e seminários: "Introdução à Educação", com Fernando de Azevedo; "Educação e Sociedade”, com Robert Havighurst; e "Psicologia", com Joel Martins.

Durante a realização do I CEEAL foi criada a Associação Latino Americana de Educadores, cuja finalidade era a aproximação crescente, por meio de intercâmbio cultural, dos educadores da América Latina.

Fernando de Azevedo, Diretor do CRPE/SP, discursou na abertura e encerramento do Curso, destacando que "o Projeto Principal da UNESCO destina-se sobretudo à formação e ao aperfeiçoamento de administradores escolares, inspetores gerais, assessores e diretores de escolas, com o fim de contribuir para a constituição e o desenvolvimento cada vez mais apurado de um corpo de professores e técnicos altamente especializados em setores diversos

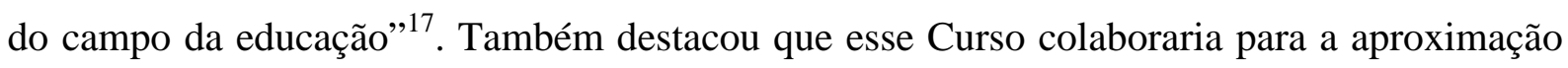
dos países da América Latina, na medida em que "aproximando educadores de todos os países da América; abrindo-lhes possibilidades para trocas de idéias e de impressões e para a intercomunicação do que seus respectivos países tenham de mais autêntico e original, nas diversas esferas da cultura; agrupando-os para cursos e atividades de objetivos comuns e pondo-os em contatos, contínuos e diretos, que podemos realizar o sonho de união latinoamericana" $^{, 18}$.

Malcolm Adiseshiah, Subdiretor Geral da UNESCO, em seu discurso de abertura do Curso, destacou a importância do planejamento educacional para a formulação realística de políticas educacionais e, além disso, afirmou a necessidade de erradicação do analfabetismo como forma de assegurar o desenvolvimento econômico e social de um país: "O caminho para aumentar a riqueza material de seus países é conseguir que todas as pessoas possam ir à escola e, além disso, melhorar essas escolas de tal forma que seus alunos se desenvolvam numa força industrial e agrícola inteligente, alfabetizada e adaptável"19.

\subsection{CEEAL.}

O II CEEAL começou em 23 de março e terminou em 12 de dezembro de 1959, contando com 50 participantes, sendo 28 bolsistas:

\begin{tabular}{|l|l|l|l|}
\hline Estrangeiros & $\mathbf{N}^{\mathbf{o}^{\mathbf{}}}$ & Brasileiros & $\mathbf{N .}^{\mathbf{0}}$ \\
\hline Argentina & 1 & Bahia & 1 \\
\hline
\end{tabular}

\footnotetext{
${ }^{17}$ Fernando de AZEVEDO, Na antevisão de um mundo só, Pesquisa e Planejamento, n. 2, p. 53.

${ }^{18}$ Fernando de AZEVEDO, A face esquecida, Pesquisa e Planejamento, n. 3, p. 67.

${ }^{19}$ Malcolm S. ADISESHIAH, A UNESCO e a luta contra o analfabetismo, Pesquisa e Planejamento, n. 2 , p. 67.
} 


\begin{tabular}{|l|l|l|l|}
\hline Bolívia & 1 & Goiás & 1 \\
\hline Colômbia & 1 & Minas Gerais & 2 \\
\hline Equador & 2 & Paraíba & 1 \\
\hline Panamá & 1 & Paraná & 1 \\
\hline Paraguai & 2 & Rio G. do Norte & 1 \\
\hline Peru & 1 & Rio G. do Sul & 1 \\
\hline Uruguai & 1 & São Paulo & 8 \\
\hline Venezuela & 1 & Sergipe & 1 \\
\hline TOTAL & $\mathbf{1 1}$ & TOTAL & $\mathbf{1 7}$ \\
\hline TOTAL GERAL & \multicolumn{2}{|l|}{$\mathbf{2 8}$} \\
\hline
\end{tabular}

Fonte: Relatório de atividades do CRPE/SP relativo ao período de junho de 1956 a agosto de 1960, Arquivo Histórico do INEP.

O Coordenador Geral do Curso continuou sendo Joel Martins (DAM) e os professores e áreas participantes foram:

\begin{tabular}{|l|l|l|}
\hline Professores/UNESCO & Formação & Cursos oferecidos \\
\hline Dr. $^{\text {a Deborah Elkins }}$ & $\begin{array}{l}\text { Ph.D. University of } \\
\text { Connecticut } \\
- \text { Prof. do Queens College, } \\
\text { New York }\end{array}$ & $\begin{array}{l}\text { - Fundamentos a Educação. } \\
\text { - Trabalho em Grupo. }\end{array}$ \\
\hline Prof. Jack Robinson & $\begin{array}{l}\text {-A.B. University of Los } \\
\text { Angeles } \\
\text {-Consultant in Elementary } \\
\text { Education, Office of County } \\
\text { Superintendent of Schools, } \\
\text { Santa Barbara, Califórnia. }\end{array}$ & $\begin{array}{l}\text { Supervisão e Administração } \\
\text { Escolar. }\end{array}$ \\
\hline
\end{tabular}

\begin{tabular}{|c|c|c|}
\hline Professores/CRPE & Formação & Cursos oferecidos \\
\hline Prof. Luiz Contier & $\begin{array}{l}\text { Diretor do I. E. Alberto } \\
\text { Comte }\end{array}$ & $\begin{array}{l}\text { - Organização de Escolas Secundárias } \\
\text { - Formação de Professores (1.o sem.) }\end{array}$ \\
\hline Prof. Celso Pasquotto & $\begin{array}{l}\text { Licenciado em Pedagogia } \\
\text { (FFCL/USP) }\end{array}$ & $\begin{array}{l}\text { Medidas e Pesquisas em Educação (1. } \\
\text { sem.) }\end{array}$ \\
\hline Prof ${ }^{a}$. Dalilla C. Sperb & $\begin{array}{l}\text { Licenciada (PUC/RS) } \\
\text { M.A.Columbia University }\end{array}$ & Administração e Supervisão \\
\hline $\begin{array}{l}\text { Prof }^{a} \text {. M. Aparecida } \\
\text { Bortoletto }\end{array}$ & $\begin{array}{l}\text { Licenciado em Pedagogia } \\
\text { (FFCL/USP) }\end{array}$ & $\begin{array}{l}\text { Psicologia e Formação de Professores } \\
\left(2 .^{\circ} \text { sem. }\right)\end{array}$ \\
\hline $\begin{array}{l}\text { Prof }{ }^{\mathrm{a}} \text {. M. Aparecida T. } \\
\text { Garcia }\end{array}$ & $\begin{array}{l}\text { Licenciada em Pedagogia } \\
\text { (FFCL/USP) }\end{array}$ & $\begin{array}{l}\text { Medidas e Pesquisas em Educação (2. } \\
\text { sem.) }\end{array}$ \\
\hline
\end{tabular}

Fonte: Relatório de atividades do CRPE/SP relativo ao período de junho de 1956 a agosto de 1960, Arquivo Histórico do INEP.

Além desses cursos, foram oferecidos os seguintes ciclos de conferências e seminários: "Sociologia Educacional", com Fernando de Azevedo; e, "O Sistema Escolar Francês", com Hélène Brullé.

O Seminário sobre o Sistema Educacional Francês realizou-se no período de 8 a 27 de junho. O Seminário consistia na discussão de dois temas: "as relações crianças-adultos em educação" e "a modernização dos métodos - os métodos ativos". Hélène Brullé refere-se a 
Fernando de Azevedo e Dewey como defensores da modernização dos métodos educacionais, dizendo que "a expansão das idéias democráticas incitou-os a procurar métodos ativos, destinados a favorecer a iniciativa, a responsabilidade individual, consideradas qualidades indispensáveis aos cidadãos de um país livre" ${ }^{20}$.

\subsection{CEEAL.}

O III CEEAL começou em 15 de março e terminou em 15 de dezembro de 1960.

A partir deste ano, o Coordenador Geral do curso passou a ser Heládio Cesar Gonçalves Antunha (Diretor da DAM).

O Curso contou com 65 participantes e os seguintes bolsistas:

\begin{tabular}{|l|l|l|l|}
\hline Estrangeiros & N. $^{\mathbf{0}}$ & Brasileiros & N. $^{\mathbf{}}$ \\
\hline Argentina & 1 & Guanabara & 1 \\
\hline Bolívia & 2 & Minas Gerais & 3 \\
\hline Chile & 1 & Pará & 2 \\
\hline Colômbia & 2 & Rio G. do Norte & 1 \\
\hline Costa Rica & 1 & São Paulo & 5 \\
\hline Equador & 2 & & \\
\hline Guatemala & 1 & & \\
\hline Haiti & 1 & & \\
\hline Honduras & 2 & & \\
\hline México & 1 & & \\
\hline Nicarágua & 1 & & \\
\hline Panamá & 1 & & \\
\hline Paraguai & 1 & & \\
\hline Uruguai & 1 & & $\mathbf{1 2}$ \\
\hline Venezuela & 1 & & \\
\hline TOTAL & $\mathbf{1 9}$ & TOTAL & \\
\hline TOTAL GERAL & \multicolumn{3}{|l|}{} \\
\hline
\end{tabular}

Fonte: Relatório de atividades do CRPE/SP relativo ao período de junho de 1956 a agosto de 1960, Arquivo Histórico do INEP.

O III CEEAL contou com os seguintes professores e áreas de estudos:

\begin{tabular}{|l|l|l|}
\hline Professores/UNESCO & Formação & Cursos oferecidos \\
\hline $\begin{array}{l}\text { Prof. Stanley A. A. } \\
\text { Applegate }\end{array}$ & $\begin{array}{l}\text { Director of Curriculum, Manhasset } \\
\text { Public School, New York }\end{array}$ & Currículo (2..$^{\circ}$ semestre) \\
\hline $\begin{array}{l}\text { Prof. Elster Clayton } \\
\text { Short }\end{array}$ & $\begin{array}{l}\text { "Educationalist", General U.S. } \\
\text { Office of Education }\end{array}$ & $\begin{array}{l}\text { Supervisão e Administração } \\
\text { Escolar (2. }{ }^{\circ} \text { sem.) }\end{array}$ \\
\hline
\end{tabular}

\begin{tabular}{|l|ll|l|}
\hline Professores/CRPE & Formação & Cursos oferecidos \\
\hline Prof. Isaías Pessoti & $\begin{array}{l}\text { Licenciado em } \\
\text { (FFCL/USP) }\end{array}$ & Filosofia & $\begin{array}{l}\text { Psicologia } \\
\text { Português }\end{array}$ \\
\hline
\end{tabular}

\footnotetext{
${ }^{20}$ Hélène BRULLÉ, A modernização dos métodos, Pesquisa e Planejamento, n. 4, p. 166.
} 


\begin{tabular}{|c|c|c|}
\hline Prof. Celso Pasquotto & $\begin{array}{l}\begin{array}{l}\text { Licenciado em Pedagogia } \\
\text { (FFCL/USP) }\end{array} \\
\end{array}$ & Medidas e Pesquisas em Educação \\
\hline $\begin{array}{l}\text { Prof. Duglas Teixeira } \\
\text { Monteiro }\end{array}$ & $\begin{array}{l}\text { Licenciado em Ciências } \\
\text { Sociais (FFCL/USP) }\end{array}$ & Sociologia \\
\hline $\begin{array}{ll}\text { Prof }^{\text {a }} \text { M. Aparecida } \\
\text { Bortoletto }\end{array}$ & $\begin{array}{l}\begin{array}{l}\text { Licenciada em Pedagogia } \\
\text { (FFCL/USP) }\end{array} \\
\end{array}$ & Formação de Professores \\
\hline $\begin{array}{l}\text { Prof }^{\mathrm{a}} \text {. M. Aparecida T. } \\
\text { Garcia }\end{array}$ & $\begin{array}{l}\text { Licenciada em Pedagogia } \\
\text { (FFCL/USP) }\end{array}$ & $\begin{array}{l}\text { Medidas e Pesquisas em Educação } \\
\text { Estatística }\end{array}$ \\
\hline $\begin{array}{l}\text { Prof }{ }^{\mathrm{a}} \text {. Maria Amélia } \\
\text { Campos Netto }\end{array}$ & $\begin{array}{l}\begin{array}{l}\text { Licenciada em Pedagogia } \\
\text { (FFCL/USP) }\end{array} \\
\end{array}$ & $\begin{array}{lll}\begin{array}{l}\text { Formação } \\
\text { (assistente) }\end{array} & \text { de } & \text { Professores } \\
\end{array}$ \\
\hline $\begin{array}{lll}\text { Prof }^{\mathrm{a}} \text {. } & \text { Lady } & \text { Lina } \\
\text { Traldi } & & \end{array}$ & $\begin{array}{l}\text { Licenciada em } \text { Pedagogia } \\
\text { (FFCL/USP) }\end{array}$ & fundamentos da Educação \\
\hline $\begin{array}{l}\text { Prof }{ }^{\mathrm{a}} \text {. Cléia de Araújo } \\
\text { Jacomelli }\end{array}$ & Prof $^{a}$. secundária de Inglês & Inglês \\
\hline
\end{tabular}

Fonte: Relatório de atividades do CRPE/SP relativo ao período de junho de 1956 a agosto de 1960, Arquivo Histórico do INEP.

Os seguintes ciclos de conferências e seminários foram realizados: "Educação Comparada", com Pedro Roselló; "Caracterologia", com Clement Feraud; "Filosofia da Educação", com John Brubacker; "Relações Humanas", com Abraham Monk; e, “Administração pública em geral e, particularmente, a escolar e seus problemas", com Fernando de Azevedo.

O Prof. Pedro Rosselló, representante do Diretor Geral da UNESCO e assistente do Prof. Jean Piaget, proferiu a oração inaugural deste Curso e, além disso, realizou uma série de conferências aos seus alunos e professores sobre Educação Comparada, tratando "da teoria das correntes educativas relativas às reformas escolares, à influência do Estado na Educação, à escola para todos e ao custo da educação" 21 .

\subsection{CEEAL.}

Este curso iniciou-se em 15 de março e terminou em 7 de dezembro de 1961. Seu Coordenador continuou sendo Heládio César G. Antunha (DAM).

Dos 41 bolsistas participantes, 39 residiram no Conjunto de Apartamentos do CRPE. Bolsistas participantes:

\begin{tabular}{|l|l|l|l|}
\hline Estrangeiros & $\mathbf{N .}^{\mathbf{0}}$ & Brasileiros & $\mathbf{N .}^{\mathbf{0}}$ \\
\hline Argentina & 7 & Amazonas & 1 \\
\hline Bolívia & 1 & Bahia & 2 \\
\hline Chile & 2 & Ceará & 1 \\
\hline Colômbia & 2 & Espírito Santo & 1 \\
\hline Costa Rica & 1 & Goiás & 1 \\
\hline Equador & 2 & Maranhão & 1 \\
\hline El Salvador & 1 & Minas Gerais & 1 \\
\hline Guatemala & 1 & Paraíba & 1 \\
\hline
\end{tabular}

\footnotetext{
${ }^{21}$ CURSO sobre educação comparada, Pesquisa e Planejamento, n. 4, p. 192.
} 


\begin{tabular}{|l|l|l|l|}
\hline Honduras & 1 & Pernambuco & 1 \\
\hline México & 1 & Rio G. do Sul & 2 \\
\hline Nicarágua & 1 & São Paulo & 4 \\
\hline Paraguai & 1 & & \\
\hline Peru & 2 & & \\
\hline Uruguai & 1 & & \\
\hline Venezuela & 1 & & \\
\hline TOTAL & $\mathbf{2 5}$ & TOTAL & $\mathbf{1 6}$ \\
\hline TOTAL GERAL & 41 \\
\hline
\end{tabular}

Fonte: Relatório de Atividades do CRPE/SP - 1961, Arquivo Histórico do INEP.

Os cursos oferecidos relacionaram-se às seguintes áreas de estudo:

1. Administração Escolar e Supervisão;

2. Problemas de Formação de Professores;

3. Supervisão e Desenvolvimento de Currículo;

4. Medidas Educacionais e Estatística;

5. Sociologia Educacional;

6. Problemas Latino Americanos de Educação;

7. Fundamentos da Educação;

8. Psicologia Educacional e Desenvolvimento da Criança;

9. Métodos e Materiais de Ensino;

10. Recursos Audiovisuais;

11. Inglês, Português e Espanhol.

Todos os participantes realizaram um trabalho monográfico sobre problemas educacionais em seus Países ou Estados de origem. Esse trabalho foi realizado em uma das seguintes áreas de especialização: "Problemas de Formação de Professores"; "Administração Escolar e Supervisão"; e, "Supervisão e Desenvolvimento de Currículo".

\section{Curso para Delegados de Ensino.}

Esse Curso foi oferecido pelo CRPE/SP, através de sua Divisão de Aperfeiçoamento do Magistério, e promovido pelo Departamento de Educação da Secretaria de Educação do Estado de São Paulo. Iniciou-se em 03 de março e terminou em 13 de março de 1958.

Fernando de Azevedo discursou nas cerimônias de abertura e de encerramento, afirmando que sempre acreditou, "por conhecer o papel sumamente importante das personalidades renovadoras e criadoras, que a educação pode modificar-se e progredir rapidamente, se constituirmos uma 'minoria ativa e operante', uma 'elite pedagógica', 
esclarecida, empreendedora e tenaz, sob cuja ação contínua se forme, cresça e se desenvolva o fermento da renovação em todas as escolas" ${ }^{\text {22 }}$.

A Divisão de Aperfeiçoamento do Magistério, com a colaboração de técnicos do Departamento de Educação, elaborou o programa de atividades do Curso que destacava dois aspectos: “a) a necessidade de uma visão geral dos problemas educacionais, num contexto filosófico, político e administrativo; b) a necessidade do conhecimento dos problemas específicos e atuais do Ensino Primário"23.

Os seguintes professores da USP realizaram conferências: Prof. Laerte Ramos de Carvalho (Filosofia da Educação), Prof. Lourival Gomes Machado (Política e Educação), Prof. José Querino Ribeiro (Administração e Educação) e Prof. Almeida Júnior (Planejamento e Educação). Serviram de Assistentes os professores José Mario Pires Azanha e Jorge Nagle (do CRPE/SP)

Como conclusão dos trabalhos, chegou-se a um consenso sobre como deveria ser a educação elementar - um processo não seletivo e sem privilégios de classe - e sobre como deveria se dar a extensão da escolaridade no ensino primário, com o acréscimo de mais dois $\operatorname{anos}^{24}$.

\section{Curso Intensivo para Inspetores Escolares do Ensino Primário no Estado de São Paulo.}

Este Curso foi mantido pelo INEP, sob o patrocínio do Departamento de Educação da Secretaria de Educação do Estado de São Paulo e contou com a colaboração da Divisão de Aperfeiçoamento do Magistério do CRPE/SP, que o ministrou.

Realizado no segundo semestre de 1958, este curso tinha a finalidade de apresentar "os conceitos atualizados de supervisão, de forma que se pudesse evoluir do conceito tradicional de supervisão como inspeção para o de supervisão como uma forma democrática de trabalho na sala de aula, com o professor" 25 .

Segundo Levantamento sobre o Inspetor Escolar, realizado pelo CRPE/SP em 1958, havia $158^{26}$ Inspetores exercendo suas funções no Estado de São Paulo. Ao todo, o Curso foi

\footnotetext{
${ }^{22}$ Fernando de AZEVEDO, Teoria e experiência educativa, Pesquisa e Planejamento, n. 2, p. 31.

${ }^{23}$ SESSÕES de Estudos para Delegados de Ensino, Pesquisa e Planejamento, n. 2, p. 243.

${ }^{24}$ NOTICIÁRIO CBPE, Divisão de Aperfeiçoamento do Magistério, Educação e Ciências Sociais, n. 8, p. 194.

${ }^{25}$ DIVISÃO DE APERFEIÇOAMENTO DO MAGISTÉRIO, Cursos de Inspetores, Relatório de Atividades do CRPE/SP - 1958, Arquivo Histórico do INEP, p. 27.

${ }^{26}$ Joanna Mader Elazari KLEIN, Problemas do Ensino Primário vistos pelo Inspetor Escolar, Pesquisa e

Planejamento, n. 4, p. 82.
} 
frequentado por 110 Inspetores $^{27}$, divididos em três turmas que frequentavam o curso por cerca de quinze dias.

As seguintes áreas de estudos foram abordadas no Curso: "Relações Humanas"; "Conceito de Supervisão"; "Avaliação de Professores"; "Professores Principiantes"; "Como ajudar aos professores, individualmente, na classe"; "Pesquisa em Ação"; e, "Planos de Ação na Profissão".

Conforme a revista Pesquisa e Planejamento, "a experiência com o primeiro grupo de Inspetores foi a mais frutífera do ponto de vista e julgamento do coordenador e dos professores do curso. Os problemas referentes à atividade profissional foram amplamente discutidos, levando gradualmente a modificações na atitude de trabalho. Conforme é possível verificar pela tabulação das respostas do questionário apresentado, o aspecto mais apreciado foi o de 'pesquisa em ação', ou atividades exercidas pelo próprio professor, enquanto executa seu trabalho. Essa preferência levou à conclusão de que os supervisores estão conscientes dos problemas existentes na escola primária, e mais ainda, conscientes da importância da sua participação na solução desses problemas" ${ }^{\text {28 }}$.

Ao final dos trabalhos, os Inspetores participantes responderam um questionário a respeito de sua avaliação do Curso. Em meio aos elogios, ele reclamaram da constante interrupção de suas atividades com a introdução de pessoas do Centro na sala de aula, perturbando o encadeamento das discussões, aulas e seminários. Os Inspetores sugeriram que fosse proibida a entrada de pessoas estranhas ao curso, que geralmente eram os pesquisadores do Centro, solicitando o preenchimento de questionários que serviriam de fonte de dados para os Levantamentos que se realizavam ou, então, fazendo convites para palestras e seminários.

\section{Cursos de Férias para o Magistério Estadual.}

A partir de 1959, a DAM, em colaboração com o Departamento de Educação, elaborou cursos de férias para o magistério estadual.

Nos cursos de 1959, participaram os orientadores das classes experimentais e os professores do II CEEAL, que "tiveram a oportunidade de reger aulas e seminários relativos a Supervisão e Administração Escolar, Metodologia para a Escola Primária e Psicologia Infantil",29.

\footnotetext{
${ }^{27}$ SESSÕES de Estudos para Inspetores Escolares, Pesquisa e Planejamento, n. 3, p. 169.

${ }^{28}$ Ibidem, p. 163.

${ }^{29}$ DIVISÃ̃ DE APERFEIÇOAMENTO DO MAGISTÉRIO, Cursos de Férias para o Magistério Estadual, Relatório de Atividades CRPE/SP - 1959, Arquivo Histórico do INEP, p. 05.
} 
Em 1960, realizaram-se os seguintes cursos de férias, por solicitação do Serviço de Expansão Cultural do Departamento de Educação:

\begin{tabular}{|l|l|l|l|}
\hline $\begin{array}{l}\text { CURSOS DE FÉRIAS DE } \\
\text { VERÃO }\end{array}$ & Professor & Local & Participantes \\
\hline Psicologia na escola primária & Lady Lina Traldi & Capital & $\begin{array}{l}\text { Professores } \\
\text { Primários }\end{array}$ \\
\hline Psicologia na escola primária & Lady Lina Traldi & Botucatu & $\begin{array}{l}\text { Professores } \\
\text { Primários }\end{array}$ \\
\hline Metodologia do cálculo & Adla Neme & Capital & $\begin{array}{l}\text { Professores } \\
\text { Primários }\end{array}$ \\
\hline Metodologia do cálculo & Adla Neme & Botucatu & $\begin{array}{l}\text { Professores } \\
\text { Primários }\end{array}$ \\
\hline $\begin{array}{l}\text { Supervisão e Administração } \\
\text { Escolar }\end{array}$ & $\begin{array}{l}\text { M. Apparecida Bortoletto e } \\
\text { Myrthes da F. Pinto }\end{array}$ & Capital & Diretores \\
\hline
\end{tabular}

\begin{tabular}{|l|l|l|l|}
\hline $\begin{array}{l}\text { CURSOS DE FÉRIAS } \\
\text { DE INVERNO }\end{array}$ & Professor & Local & Participantes \\
\hline $\begin{array}{l}\text { Psicologia na escola } \\
\text { primária }\end{array}$ & Lady Lina Traldi & Assis & Professores Primários \\
\hline $\begin{array}{l}\text { Relações entre a escola } \\
\text { e a comunidade }\end{array}$ & Duglas Monteiro & Capital & Professores Primários \\
\hline $\begin{array}{l}\text { Meios de comunicação } \\
\text { audiovisual }\end{array}$ & Equipe SRAV & Capital & Diretores \\
\hline Metodologia da Leitura & Nelly de Camargo & $\begin{array}{l}\text { S. Bernardo do } \\
\text { Campo }\end{array}$ & Professores Primários \\
\hline
\end{tabular}

Fonte: Relatório de atividades do CRPE/SP relativo ao período de junho de 1956 a agosto de 1960, Arquivo Histórico do INEP.

Em janeiro de 1961, realizaram-se seguintes os cursos de férias:

\begin{tabular}{|l|l|l|}
\hline CURSOS DE FÉRIAS & Professor & Participantes \\
\hline $\begin{array}{l}\text { Administração Escolar e } \\
\text { Supervisão }\end{array}$ & Stanley Applegate & Diretores de Escola Primária \\
\hline Metodologia do Cálculo & Adla Neme & Professores Primários \\
\hline Psicologia na Escola primária & Lady Lina Traldi & Professores Primários \\
\hline
\end{tabular}

Fonte: Relatório de Atividades do CRPE/SP - 1961, Arquivo Histórico do INEP.

\section{Cursos do Serviço de Recursos Audiovisuais.}

Inaugurado em dezembro de 1960, o Serviço de Recursos Audiovisuais realizou, ao longo de 1961, doze cursos que duravam, em geral, de uma a duas semanas e destinaram-se a:

1. Diretores de Escolas Primárias,

2. Diretores de Escolas Industriais,

3. Professores da Escola de Polícia,

4. Professores do Curso Secundário do Estado de São Paulo,

5. Professores de Curso Primário,

6. Alunos das Faculdade de Serviço Social de Lins e Campinas,

7. Enfermeiras do Hospital das Clínicas de São Paulo, 
8. Professores do Colégio Estadual "Prof. Macedo Soares",

9. Encarregados de Treinamento na Indústria,

10. Enfermeiras e Educadoras Sanitárias da Faculdade de Higiene e Saúde Pública da Universidade de São Paulo.

Esses cursos eram solicitados pelos Diretores de Escolas, de Faculdades, pelo Departamento de Educação e pela DAM (no caso dos cursos para os bolsistas do CEEAL). Seus objetivos eram divulgar filmes educativos e apresentar novas formas de utilização de recursos audiovisuais aos professores, diretores e encarregados de treinamentos.

Os bolsistas do Curso de Especialistas em Educação para a América Latina realizavam o curso em um formato mais completo, durante dois meses.

\section{I Seminário para Treinamento de Pessoal para Pesquisas Educacionais.}

Os Diretores dos cinco Centro Regionais de Pesquisas Educacionais realizaram uma reunião, em São Paulo, em fevereiro de 1959, onde decidiram pela organização de um curso para treinamento de pesquisadores educacionais. Esse treinamento fazia-se necessário pela dificuldade que os Centros enfrentavam para contratar pesquisadores habilitados. Geralmente era necessário formar os pesquisadores nos próprios Centros, através da prática na realização de levantamentos.

A UNESCO interessou-se pela idéia e destinou recursos para contratar "técnicos estrangeiros que, juntamente com um grupo de brasileiros, especializados em pesquisa educacional, pudessem preparar os quadros de pesquisa necessários, e aperfeiçoar os já existentes" 30 .

A UNESCO e o INEP ofereceram 46 bolsas de estudos a pessoas que "exerçam funções técnicas na alta administração educacional dos diversos Estados da Federação ou nos CRPEs, a fim de realizarem, no ano de 1962, no CRPE/SP, estudos teóricos, estágios, observações e treinamento em atividades de campo ligadas à pesquisa educacional”31.

O Seminário foi elaborado por Robert Brackenbury (contratado pela UNESCO) e por Heládio César G. Antunha (Diretor da DAM) e realizou-se de $1 .^{\circ}$ de março a 15 de dezembro de 1962.

\footnotetext{
${ }^{30}$ I SEMINÁRIO para Treinamento de Pessoal para Pesquisas Educacionais, Pesquisa e Planejamento, n. 5, p. 224.

${ }^{31}$ Ibidem, p. 224.
} 
Conforme a revista Pesquisa e Planejamento, "idéia que presidiu ao planejamento e à organização do Seminário é a de que se torna indispensável introduzir nas Secretarias de Educação o planejamento cientificamente conduzido. Em consequência, será necessário preparar e aperfeiçoar pessoal para pesquisas educacionais, a fim de que possam liderar os planos de reforma a serem realizados pelas diversas Secretarias de Educação dos Estados, bem como conduzir as pesquisas programadas pelos vários CRPE, mantidos pelo INEP”32.

Renato Jardim Moreira, Diretor da Divisão de Estudos e Pesquisas Sociais, também trata da necessidade de se realizarem cursos para o treinamento de pessoal em pesquisa, uma vez que as Faculdades de Filosofia não estavam mais conseguindo cumprir esse papel: "A condição para se realizar este programa a longo prazo é que se desenvolva, como atividade de apoio, a formação e o aperfeiçoamento de pessoal de pesquisa. Nas ciências Humanas, essa atividade tem sido exercida até agora, principalmente, pelas Faculdades de Filosofia; no campo da Sociologia pode-se colocar a seu lado a Escola de Sociologia e Política. Essas instituições beneficiam-se de vários programas para contratar professores estrangeiros e distribuir bolsas de estudos no exterior. $\mathrm{O}$ treinamento em pesquisa, no entanto, ainda deixa muito a desejar. Isto vai se refletir na atividade científica, pois as instituições de pesquisa recebem um pessoal com pouca prática. Uma solução, talvez, para esse problema seria incentivar o desenvolvimento dos atuais cursos de treinamento em pesquisa" ${ }^{\text {"33. }}$.

\section{Considerações Gerais.}

A maioria dos cursos realizados no CRPE/SP durante o período estudado, relacionavam-se diretamente ao aprimoramento da formação profissional dos professores, diretores de escolas, delegados de ensino ou inspetores escolares, ligados ao Ensino Primário, visando o aperfeiçoamento desses profissionais no exercício de suas funções.

Esses cursos estavam sob a responsabilidade da Divisão de Aperfeiçoamento do Magistério (DAM) que, até 1959, esteve sob direção de Joel Martins e, a partir de 1960, teve Heládio César Gonçalves Antunha como diretor.

O objetivo mais geral dos cursos era tornar os profissionais da área educacional aptos a desempenhar seu papel no processo de renovação educacional no Estado de São Paulo. Em linhas gerais, procurava-se iniciar os trabalhos com a discussão dos problemas educacionais

\footnotetext{
${ }^{32}$ Ibidem, p. 224.

${ }^{33}$ Renato Jardim MOREIRA, Planejamento Educacional para o Estado de São Paulo, Pesquisa e Planejamento, n. 4 , p. 10.
} 
considerados mais importantes. O segundo passo era procurar despertar nos educadores a preocupação com os métodos da pesquisa científica e com a necessidade de se conhecer princípios de ciências afins, como sociologia e antropologia. O último passo era discutir os benefícios e a necessidade de se estabelecer um planejamento integral da educação como forma de solução dos problemas do Ensino Primário no Estado.

Os cursos eram financiados pela Secretaria da Educação do Estado de São Paulo, pelo INEP ou pela UNESCO, contando com professores contratados, bolsas de estudos aos participantes ou licenças remuneradas para os funcionários do Estado.

O único curso que não se destinou especificamente aos educadores vinculados ao ensino primário foi o Seminário para Treinamento de Pessoal para Pesquisas Educacionais planejado em 1959, mas realizado somente em 1962. Este Seminário, patrocinado pela UNESCO e pelo INEP, tinha por objetivo formar os pesquisadores necessários para a realização de pesquisas educacionais em todo o Brasil. Ele surgiu em função da dificuldade encontrada pelos Centros Regionais de Pesquisas Educacionais em contratar mão de obra apta à realização dos levantamentos, pesquisas e planos pretendidos. Note-se que o CRPE/SP tinha a facilidade de estar vinculado à Faculdade de Filosofia, Ciências e Letras da USP e nela encontrar os pesquisadores de que precisava. Entretanto, os demais Centros Regionais encontravam dificuldades em relação à esse problema.

É interessante observar como as questões de gênero eram tratadas na época. Um elemento para essa observação pode ser encontrado no seguinte trecho de um artigo publicado na revista Pesquisa e Planejamento que informava sobre a realização do I Seminário para Treinamento de Pessoal para Pesquisas Educacionais: "Pretende-se selecionar o maior número possível de elemento do sexo masculino, pois é provável que, em anos subsequentes, eles tenham mais oportunidades de ocupar posições estáveis de liderança, relacionadas com o planejamento e a pesquisa em educação",34.

Os professores que ministravam os cursos e seminários eram, em sua maioria, vinculados à Faculdade de Filosofia, Ciências e Letras da USP. Também havia os professores estrangeiros, contratados pela UNESCO, que atuaram nos Cursos de Especialistas em Educação e no Seminário para Treinamento de Pessoal para Pesquisas.

\footnotetext{
${ }^{34}$ I SEMINÁRIO para Treinamento de Pessoal para Pesquisas Educacionais, Pesquisa e Planejamento, n. 5, p. 228.
} 
De modo geral, todos os cursos e seminários realizados estavam relacionados às pesquisas e levantamentos que se realizavam no Centro, uma vez que o principal objeto de análise era o mesmo: o ensino primário no Estado de São Paulo.

Os pesquisadores do Centro sempre buscavam encontrar nos participantes dos Cursos informantes e colaboradores para suas pesquisas. Tanto que no questionário de avaliação do Curso Intensivo para Inspetores Escolares, seus participantes reclamaram das constantes perturbações ao andamento dos trabalhos do Curso pelos pesquisadores do Centro, que insistiam em distribuir questionários que forneceriam dados para o Levantamento sobre o Inspetor Escolar do Estado de São Paulo. Levantamento que, por sua vez, estava ligado ao Levantamento do Ensino Primário. 


\section{Capítulo 3 - Pesquisas, Levantamentos e Estudos.}

“A minha idéia de 'pesquisa educacional', além de compreender tudo que é realmente pesquisa, incluiria algo de mais geral, que devia transmitir a todo o sistema escolar, da classe à sala do diretor, a idéia de que todo esse imenso aparelho é um aparelho de coleta e registro de fatos; que tais fatos constituem a matéria-prima para a pesquisa; e que, portanto, se forem melhoradas as formas de registo dos fatos e os mesmos se fizerem cumulativos - na escola e na classe se encontrará sempre um material abundantíssimo para o estudo dos alunos, dos métodos e do conteúdo do ensino",

Este outro trecho daquela carta de Anísio Teixeira a Fernando de Azevedo - já citada no início do capítulo anterior - apresenta um elemento fundamental para que a pesquisa educacional que seria desenvolvida no Centro Regional de Pesquisas Educacionais de São Paulo seja melhor compreendida. Todo o sistema educacional é tido como "um aparelho de coleta e registro de fatos", ou seja, através do desenvolvimento de instrumentos de observação do aluno, do professor e do cotidiano escolar seria possível acumular dados qualitativos a respeito da escola e com eles reformá-la. Esta reforma se daria, segundo Anísio Teixeira, através da ação conjunta de todo o magistério e do pessoal do Centro, visando a melhoria da formação profissional dos educadores, o desenvolvimento de diversos materiais de ensino e, sobretudo, a mudança na forma que os professores encaram a educação e o papel que nela devem desempenhar.

As pesquisas que se desenvolveram no CRPE/SP, de 1956 a 1961, estavam diretamente relacionadas aos principais objetivos do Centro, que foram apresentados no primeiro número da revista Pesquisa e Planejamento como sendo: "estudar as condições ambientes, promover levantamentos e realizar pesquisas para a compreensão cada vez mais nítida da estrutura e do funcionamento das instituições pedagógicas e dos diferentes meios socioculturais em que elas se inserem e a que se devem ajustar, em adaptações progressivas"2. Através da investigação científica, buscava-se atingir uma planificação racional da ação política, com a finalidade de reestruturar a educação brasileira.

A Divisão de Estudos e Pesquisas Sociais (DEPS) e a Divisão de Estudos e Pesquisas Educacionais (DEPE) estavam encarregadas de planejar e coordenar o andamento das pesquisas e deveriam - conforme consta no Plano de Trabalho do Centro - "aproveitar, preferencialmente, os serviços e as possibilidades de pesquisa das cadeiras do Departamento

\footnotetext{
${ }^{1}$ Trecho de carta de Anísio TEIXEIRA a Fernando de Azevedo, de 24 de outubro de 1956, Arquivo Fernando de Azevedo - IEB/USP. Esta carta encontra-se reproduzida no Anexo C.
} 
de Sociologia e Antropologia e do Departamento de Educação"3 da Faculdade de Filosofia, Ciências e Letras da USP.

$\mathrm{Na}$ inauguração do CRPE/SP, definiram-se dois Levantamentos que deveriam incidir sobre alguns dos aspectos mais gerais da escola primária e normal (foram os Levantamentos do Ensino Primário e Secundário do Estado de São Paulo). Também definiram-se dois projetos de pesquisa, um no campo da psicologia (Ficha de Observação de Alunos) e outro no campo da pedagogia (Escalas de Escolaridade). Além desses projetos maiores, havia as pesquisas financiadas pelo Centro e os estudos que os próprios pesquisadores foram realizando ao longo do seu trabalho de pesquisa e que colaboravam com os projetos inicialmente planejados.

As informações relativas às pesquisas desenvolvidas no Centro, de 1956 a 1961, procuram apresentar os seguintes dados: o período em que foi desenvolvida; a Divisão ou pesquisadores responsáveis pela sua execução; seus objetivos e justificativas para a realização; financiamentos pretendidos e obtidos; a metodologia de pesquisa adotada e suas justificativas; as alterações sofridas pelo projeto inicial ao longo do processo de pesquisa e os motivos dessas alterações; e, as conclusões encontradas ou a situação em que a pesquisa se encontrava em 1961 (último ano estudado neste trabalho).

\section{Levantamento do Ensino Primário do Estado de São Paulo (LEP).}

Este Levantamento iniciou-se em 1957 e tinha como objetivo mais amplo "determinar os aspectos positivos e as deficiências da escola"4. O Levantamento do Ensino Primário deveria fornecer uma visão global de algumas condições gerais do ensino primário no Estado de São Paulo, da qual se pudesse partir para a elaboração de hipóteses para futuras pesquisas específicas no campo educacional ${ }^{5}$.

O projeto de pesquisa estava sob a responsabilidade da Divisão de Estudos e Pesquisas Sociais (DEPS), dirigida por Renato Jardim Moreira, e propunha-se a estudar os seguintes aspectos da organização do sistema escolar:

1. Condições materiais da escola: prédios e instalações.

\footnotetext{
${ }^{2}$ [Fernando de AZEVEDO], Apresentação, Pesquisa e Planejamento, n. 1, p. 01.

${ }^{3}$ PLANO de Trabalho do Centro Regional de Pesquisas Educacionais de São Paulo/maio de 1956, Arquivo CRPE - Centro de Memória/USP.

${ }^{4}$ LEVANTAMENTO do Ensino Primário do Estado de São Paulo, Pesquisa e Planejamento, n. 1, p. 112.

${ }^{5}$ Ibidem, p. 115.
} 
2. Número de professores em exercício.

3. Situação funcional e profissional do professor.

4. Condições didáticas.

5. Condições de alimentação e saúde dos alunos.

6. Instituições auxiliares da escola.

7. Frequência e aproveitamento escolar.

8. Procura e matrícula escolar.

9. Receita e despesa escolar.

Pretendia-se, também, "coligir dados que permitissem determinar as áreas ecológicas do Estado com seus centros de dominância, para o estudo da distribuição geográfica das escolas e da remoção dos professores. Esses dados permitiriam examinar os problemas relativos ao ajustamento profissional do professor primário e dariam elementos para o planejamento em alguns setores da administração escolar" ${ }^{\prime 6}$. O projeto de pesquisa se completava com a idéia de construção de um Cadastro das Escolas Primárias que, classificando as escolas, constituiria um "sistema de referência para a elaboração de esquemas de amostragem em futuras pesquisas"7.

A revista Pesquisa e Planejamento destacou no artigo de divulgação deste Levantamento que a falta de colaboração oficial da Secretaria de Educação do Estado de São Paulo restringiu a extensão da pesquisa. A proposta de realização de um convênio entre a Secretaria de Educação e o CRPE/SP foi rejeitada. A Secretaria alegou já possuir todos os dados pedidos e um novo levantamento, no seu entender, seria um trabalho desnecessário e dispendioso.

Assim, em vez de se realizar um levantamento por recenseamento e em todo o Estado, resolveu-se realiza-lo por amostragem e restringi-lo às escolas que integravam as cinco Delegacias de Ensino da capital paulista ${ }^{8}$. Diminuiu-se a ênfase antes colocada nos problemas ligados à distribuição geográfica das escolas e abandonaram-se alguns tópicos inicialmente propostos.

Além de ser determinada pela restrição orçamentária, a escolha do município de São Paulo como universo de análise justificava-se pelo fato de que esta cidade detinha $1 / 4$ das crianças matriculadas nas escolas elementares de todo o Estado e 1/6 dos alunos de toda a

\footnotetext{
${ }^{6}$ LEVANTAMENTO do Ensino Primário: procedimentos, Pesquisa e Planejamento, n. 2, p. 74.

${ }^{7}$ Ibidem, p. 74.

${ }^{8}$ LEVANTAMENTO do Ensino Primário do Estado de São Paulo, Pesquisa e Planejamento, n. 1, p. 111-2.
} 
região servida pelo Centro. Também partia-se de hipótese de que o sistema escolar, organizado para atender comunidades relativamente pequenas, deveria estar apresentando maiores problemas em um centro urbano, cujo crescimento ultrapassara todas as previsões possíveis ${ }^{9}$.

O pessoal necessário para o levantamento seria contratado pelo CRPE e, na fase de coleta, poderiam ser recrutados alunos da Faculdade de Filosofia da USP para servir de coletores de dados. Com o desenvolvimento dos quadros do CRPE, formou-se uma equipe encarregada exclusivamente deste Levantamento.

Para que fosse possível avaliar a fidedignidade dos dados oficiais existentes na Secretaria da Educação e no Departamento de Estatística do Estado de São Paulo, o pessoal do CRPE/SP resolveu aplicar os questionários elaborados (para diretores e professores) sobre uma amostra de $20 \%$ das escolas. Essa amostra constituía-se de 55 grupos escolares, 153 escolas isoladas e 72 escolas particulares, em um total de 280 escolas ${ }^{10}$.

Definiu-se como Ensino Primário, para o LEP, o ensino "ministrado no curso fundamental comum, destinado às crianças de mais de 7 e menos de 14 anos. Eliminaram-se, assim, os cursos pré-primário, supletivo, popular noturno, complementar e os de classes especiais. Nesses termos, os grupos escolares estaduais, as escolas isoladas estaduais e as escolas particulares localizadas no Município de São Paulo - unidades escolares responsáveis pelo ensino primário tal como foi definido acima - passaram a constituir, com os respectivos professores, a população do Levantamento" "11. Por existirem em pequeno número, as escolas primárias municipais mantidas pela Prefeitura de São Paulo, ficaram fora do Levantamento ${ }^{12}$.

Dois tipos de questionário foram elaborados para a coleta de dados, um para ser preenchido pela direção das escolas e outro, pelos professores ${ }^{13}$. Argumentava-se, em favor do uso do questionário, que o LEP constituiria o passo inicial de um programa integrado de pesquisas. "Se provasse bem, devido ao baixo custo de sua aplicação, abrir-se-iam ótimas perspectivas para a realização de um grande número de pesquisas sobre a escola, com despesas relativamente pequenas" ${ }^{, 14}$.

\footnotetext{
${ }^{9}$ DIVISÃO DE ESTUDOS E PESQUISAS SOCIAIS, Levantamento do ensino primário, Relatório de Atividades CRPE/SP - 1957, Arquivo Histórico do INEP, p. 52.

${ }^{10}$ Ibidem, p. 53.

${ }^{11}$ LEVANTAMENTO do Ensino Primário: procedimentos, Pesquisa e Planejamento, n. 2, p. 79.

${ }^{12}$ LEVANTAMENTO do Ensino Primário: primeiros resultados, Pesquisa e Planejamento, n. 2, p. 103.

${ }^{13}$ LEVANTAMENTO do Ensino Primário: procedimentos, Pesquisa e Planejamento, n. 2, p. 84.

${ }^{14}$ Ibidem, p. 86.
} 
O relatório de avaliação dos procedimentos de pesquisa destacou que o questionário provou bem para os informantes selecionados (professores, diretores e auxiliares), apesar de mostrar-se necessário um contato direto e pessoal com os informantes para complementar informações. Além disso, "a experiência do Levantamento mostrou que, em São Paulo, o aproveitamento dos dados existentes [da Secretaria da Educação e DEESP] sobre o sistema educacional deve ser feito com algum cuidado"15.

A respeito da colaboração dos administradores e dos professores em responder os questionários, o relatório informa que "esta cooperação não deve originar-se de uma boa vontade genérica, mas deve ser consequência de uma tomada de consciência, pelo magistério do papel que a pesquisa científica pode ter na solução dos problemas educacionais. Dessa consciência decorrerá certamente, uma atitude favorável às pesquisas educacionais que, além de facilitar a coleta e aumentar a fidedignidade dos dados, criará condições que propiciam a aplicação prática dos resultados do estudo científico da educação"16.

Acreditava-se que "o principal empecilho para o aparecimento dessa consciência está na constante solicitação de dados ao magistério, sem uma correspondente divulgação ampla dos resultados dessas pesquisas e sem que professores e administradores escolares sintam qualquer efeito prático que se ligue a essas investigações" ${ }^{\text {17 }}$. Portanto, sugeria-se que houvesse uma "planificação da investigação educacional", com a finalidade de evitar o excesso de pedidos de dados que geram um efeito negativo sobre a colaboração dos professoresinformantes além de, geralmente, coligir dados já conhecidos.

A primeira e parcial apresentação de resultados do LEP, feita em 1958, mostra os resultados do Município de São Paulo, válidos para o ano de 1957. Essa apresentação tinha "mais o caráter de descrição do que de explicação de certos aspectos do sistema escolar"18. Os resultados referiam-se à matrícula segundo o tipo de escola; matrícula segundo a série; matrícula segundo o tipo de classe; matrícula segundo a duração do período letivo diário; e, matrícula segundo as características do prédio escolar.

\footnotetext{
${ }^{15}$ Ibidem, p. 97.

${ }^{16}$ Ibidem, p. 100.

${ }^{17}$ Ibidem, p. 101.

${ }^{18}$ LEVANTAMENTO do Ensino Primário: primeiros resultados, Pesquisa e Planejamento, n. 2, p. 104.
} 
Em $1959^{19}$ divulgaram-se os resultados referentes a 1958. Com a obtenção desses resultados foi possível a realização de uma comparação com os dados do ano anterior e chegar a algumas observações a respeito do ensino primário:

1. Matrícula segundo a entidade mantenedora: observou-se o desinteresse da iniciativa particular pelo ensino primário;

2. Matrícula segundo a série: as matrículas decrescem à medida que avançam as séries. Apesar disso, se comparado com o ano de 1957, 1958 apresentou um decréscimo menos acentuado;

3. Matrícula por classe: a matrícula média por classe, no Município de São Paulo, era 34,7 alunos por classe;

4. Matrícula segundo duração do período letivo diário: 69,5\% dos alunos matriculados nas escolas primárias de São Paulo recebiam no máximo 3h e 15 min de aula por dia;

5. Matrícula segundo as características do prédio escolar: grande número de alunos frequentam aulas nos chamados "galpões de emergência".

Neste relatório, os pesquisadores da DEPS opinaram sobre a viabilidade de desenvolver-se um programa de expansão da rede: "tendo em vista a possível realização de um programa de expansão da rede, pretende-se insistir na necessidade de que essa expansão venha antes a eliminar alguns defeitos gritantes do sistema escolar do que ligar-se a um programa de extensão da escolaridade [de 4 para 6 anos]: os 69,5\% de alunos com 3:15 horas e menos de aula por dia, o grande número de crianças que estão em classes com 35 e mais alunos e os 33,4\% que assistem às aulas em galpões" ${ }^{20}$.

Os técnicos concluem esse relatório afirmando: "Se todas as escolas viessem a atender a certos padrões mínimos de funcionamento - prédios adequados, classes com 35 alunos e períodos letivos diários de 4 horas - o sistema não comportaria as matrículas atuais"21.

No último relatório publicado na revista Pesquisa e Planejamento a respeito do LEP ${ }^{22}$ comparam-se dados referentes à escola primária paulista no período de 1934 a 1957, procurando-se fazer um balanço dos resultados efetivos das intenções de renovação do sistema educacional.

Algumas características da escola primária paulistana são destacadas:

\footnotetext{
${ }^{19}$ ALGUNS característicos da escola primária no município de São Paulo, em 1958, Pesquisa e Planejamento, n. 3, p. 107.

${ }^{20}$ Ibidem, p. 119-20.

${ }^{21}$ Ibidem, p. 120.
} 
1. Houve grande expansão da rede escolar primária no período. Esta expansão, entretanto, não se apoiou num programa de construção dos edifícios escolares necessários para atender ao aumento da procura. "Deve-se notar que o galpão de madeira - solução de emergência adotada em 1948 para atender à crescente procura de escolas - acabou por constituir, praticamente, o único tipo de construção escolar que se acrescentou à rede. De 1954 a 1958, embora o número de grupos escolares se elevasse de 169 a 273, nenhum prédio de alvenaria foi acrescentado aos existentes anteriormente" 23 .

2. Houve redução da carga horária escolar para aumentar o número de vagas e manter o número de anos do ensino primário (4 anos).

3. A expansão da rede não se fez acompanhar da substituição de práticas de ensino da escola tradicional pelas da escola nova. O grau em que se introduziram as técnicas da escola nova foi avaliado pela utilização, ou não, de recursos audiovisuais modernos (cinema educativo, por exemplo) em comparação com aqueles que já eram utilizados pela escola tradicional (mapas e cartazes).

4. A expansão da rede representou a democratização do ensino, mas não eliminou o caráter seletivo da escola tradicional. "A escola primária passou a ser procurada por quase todos, mas concluída por poucos",24.

Em relação às bibliotecas, o relatório conclui que "a criação de bibliotecas, depois de um surto no período de 1930-37, não mais se expandiu e o seu uso, como auxiliar do ensino de classe, é aleatório e não sistemático"25.

Avaliando, de maneira geral, a escola primária em São Paulo o relatório afirma que "as novas práticas educacionais, advogadas pelo movimento renovador de nossa educação, não se integraram no sistema escolar primário do Município de São Paulo. Encontrando receptividade no magistério, como indica a expansão do jornal escolar, a redução do período letivo diário - expediente adotado para atender a falta de prédios - antes mesmo do que a inexistência de recursos didáticos, não permitiu a introdução dessas técnicas educativas, que exigem escola de tempo integral. Nessas condições, a escola primária continuou a ensinar, apenas, a escrever, ler e contar, papel que lhe cabia numa sociedade em que a família e a religião completavam a educação. É uma escola que não corresponde às exigências da

\footnotetext{
${ }^{22}$ LEVANTAMENTO do Ensino Primário (resultados relativos à escola), Pesquisa e Planejamento, n. 4, p. 5782.

${ }^{23}$ Ibidem, p. 64.

${ }^{24}$ Ibidem, p. 61 .

${ }^{25}$ Ibidem, p. 69.
} 
sociedade de base urbana e industrial, onde a cultura se seculariza e a família não pode mais exercer esse papel complementar. Acrescente-se ainda que a escola se manteve seletiva, quando o Estado democrático moderno exige de todos os cidadãos o domínio de um conjunto de conhecimentos básicos"26.

Defendendo o "planejamento integral da educação", o relatório conclui: "a consciência da necessidade individual de educação sistemática, nascida com o desenvolvimento da nossa sociedade, a insatisfação que existe em relação ao sistema educacional, manifestada na constante reivindicação de novas escolas, e as potencialidades do magistério, como se observou no caso do jornal escolar, esses três elementos, constituem condições favoráveis para a execução de um programa de renovação educacional. Mas esse programa deve resultar de um planejamento integral da educação e não representar uma solução para problemas imediatos, mais salientes. Planejar a melhoria de um setor, sem que o contexto mais geral da educação seja considerado, apresenta risco de, uma vez mantidos os outros característicos do sistema educacional também responsáveis pelo atual padrão de ensino, levar ao malogro a inovação e ao descrédito seus responsáveis ${ }^{27}$.

Através dessas declarações, observa-se que os pesquisadores avaliaram a condição da escola primária existente em São Paulo tendo como parâmetro uma interpretação do que seria uma escola que respeitasse as idéias do movimento de renovação educacional divulgado pelos defensores da chamada Escola Nova, da época. A solução para os problemas observados seria a realização de um planejamento integral da educação que permitisse uma aplicação dos preceitos daquele movimento, representados pelo ideal de ampliação do período letivo diário e adoção de novas práticas educacionais como, por exemplo, o cinema educativo e o jornal escolar.

O Levantamento do Ensino Primário proporcionou a realização de estudos relacionados à Estatística Educacional e aos Inspetores Escolares que serão apresentados neste capítulo.

\footnotetext{
${ }^{26}$ Ibidem, p. 79-80.

${ }^{27}$ Ibidem, p. 80-1.
} 


\section{Levantamento do Ensino Secundário (oficial) e Normal (oficial e particular) do Estado de São Paulo.}

Logo após a inauguração do CRPE/SP, planejou-se a realização de um Levantamento destinado a determinar as qualidades positivas e negativas da Escola Normal. Entretanto, a Prof ${ }^{a}$. Maria José Garcia Werebe, da FFCL/USP, apresentou ao Centro, em 1956, um projeto de pesquisa que tinha três objetivos: "1. Conhecer a qualificação profissional e as condições de trabalho dos professores e diretores dos cursos secundário e normal do Estado de São Paulo; 2. Conhecer a opinião dos professores e diretores sobre as deficiências e dificuldades do ensino secundário e normal; e, 3. Conhecer a matrícula, aprovação, reprovação e evasão escolar no quinquênio 1952-1956 para esse nível de ensino, ${ }^{\text {28 }}$. Na realidade, seu projeto propunha-se a dar continuidade a uma pesquisa que já havia sido iniciada em 1954.

O CRPE/SP patrocinou esta pesquisa através da Divisão de Estudos e Pesquisas Educacionais e, como os esforços do Centro concentraram-se na realização do Levantamento do Ensino Primário, a pesquisa da Prof ${ }^{\text {a }}$ Maria José Werebe se tornou a única a abordar o ensino secundário e normal que se desenvolveu no Centro.

Samuel Werebe foi contratado como coordenador da pesquisa e três pesquisadoras passaram a auxiliar os trabalhos (Maria Aparecida R. Cintra, Maria Aparecida Bortoletto e Myrthes da Fonseca Pinto). Posteriormente, porém, a pesquisa obteve o apoio oficial e ajuda material do Departamento de Educação e da Chefia do Ensino Secundário e Normal do Estado de São Paulo (através do Prof. Solón Borges dos Reis).

Com o financiamento oficial decidiu-se ampliar o objeto de estudo e colher o maior número possível de dados, com a finalidade de "fornecer elementos para o estudo dos problemas criados pelo aumento rápido da rede escolar e para o estudo daquelas instituições, nos seus pontos capitais: diretor, professor e aluno" 29 . Conhecendo a qualificação profissional dos professores e diretores das escolas secundárias e normais - suas opiniões sobre os principais problemas escolares, suas condições de trabalho, suas necessidades - os resultados desta pesquisa poderiam servir de base para a análise da realidade escolar paulista ${ }^{30}$.

O questionário elaborado para a coleta de dados compreendia duas partes: "a primeira, visando obter informações sobre a qualificação profissional de professores e diretores,

\footnotetext{
${ }^{28}$ DIVISÃO DE ESTUDOS E PESQUISAS EDUCACIONAIS, Pesquisa financiada pelo CRPE sob o controle da DEPE, Relatório de Atividades CRPE/SP - 1957, Arquivo Histórico do INEP, p. 43.

${ }^{29}$ LEVANTAMENTO do Ensino Secundário e Normal do Estado de São Paulo, Pesquisa e Planejamento, n. 2, p. 233.

${ }^{30}$ Ibidem, p. 233.
} 
condições de trabalho, e suas opiniões sobre as deficiências do ensino; a outra, destinada a registrar dados sobre o movimento escolar no que se refere a matrícula, aprovação e reprovação dos alunos nos cursos secundário e normal, no quinquênio 1952-1956"31.

O Relatório de Atividades do Centro de $1957^{32}$, apresenta um histórico do desenvolvimento dessa pesquisa, que iniciou-se em 1954. Neste ano, intermédio do Departamento de Educação, foram remetidos a todos os estabelecimentos de ensino secundário e normal, cerca de 6.000 questionários para professores e diretores. Apenas 1.500 foram devolvidos.

Em 1956, novamente por intermédio do Departamento de Educação, foi feita nova remessa para os estabelecimentos cujos professores e diretores não haviam respondido o questionário anterior. Cerca de 2.000 foram devolvidos.

Em 1957, com o financiamento da pesquisa pelo CRPE/SP, fez-se o controle dos questionários recebidos, eliminados os repetidos (muitos professores responderam duas vezes) e feita nova remessa. Desta vez, o Diário Oficial do Estado publicou o modelo dos questionários e cartas do Secretário da Educação, do Diretor do Departamento da Educação e do Diretor do CRPE/SP solicitando a colaboração no encaminhamento das respostas.

Para que fosse possível a obtenção da relação completa dos professores em exercício foram consultados os arquivos do Departamento de Educação e da Secretaria da Fazenda, ambos incompletos. Finalmente, decidiu-se solicitar a cada diretor de escola que enviasse a relação dos professores de seu estabelecimento. Essa relação permitiu localizar os professores que não responderam os questionários e eliminar os questionários dos professores afastados, obtidos nos anos anteriores.

Foram recebidos cerca de 4.700 questionários de professores e cerca de 350 de diretores. Faltavam cerca de 600 questionários de professores e 100 de diretores.

Em relação aos dados sobre os alunos, dos 354 estabelecimentos de ensino secundário do interior e dos 114 da Capital, foram recebidos dados de 340 estabelecimentos do interior e 107 da Capital.

Os dados foram codificados em 1957. O Serviço de estatística da Secretaria da Agricultura colaborou com a tabulação dos dados referentes ao corpo discente.

\footnotetext{
${ }^{31}$ Ibidem, p. 234.

${ }^{32}$ DIVISÃO DE ESTUDOS E PESQUISAS EDUCACIONAIS, Pesquisa financiada pelo CRPE sob o controle da DEPE, Relatório de Atividades CRPE/SP - 1957, Arquivo Histórico do INEP, p.43-4.
} 
Em junho de 1958, o relatório final da pesquisa foi entregue para ser publicado na Série de "Monografias" do CRPE/SP.

\section{Ficha de Observação de Alunos (FOA).}

Este projeto, iniciado em 1957, estava sob a responsabilidade da Divisão de Estudos e Pesquisas Educacionais (DEPE).

Sua realização foi sugerida pessoalmente por Anísio Teixeira em uma reunião realizada no CRPE/SP. Anísio Teixeira entendia que com o desenvolvimento de instrumentos propícios ao registro de fatos escolares seria possível obter um conhecimento qualitativo a respeito desses fatos:

"Haveria então uma ficha do aluno, desenvolvida e cumulativa, que nos daria a história do aluno na escola. Uma ficha idêntica do professor. E, possivelmente, outra de fatos escolares, algo como o diário de bordo de um navio. Com esses três documentos, teríamos sempre um conjunto de fatos seguidos e, repito, acumulados, isto é, longitudinais sobre o aluno, o professor e a escola: verdadeiro tesouro para pesquisas de toda espécie”.".

As fichas do professor e a respeito dos fatos escolares não chegaram a ser desenvolvidas, mas a Ficha de Observação de Alunos foi elaborada através do trabalho dos seguintes pesquisadores:

1. José Mario Pires Azanha

2. Raja Nassar

3. Frederico de Barros Brotero
4. Lourdes Brito

5. Lygia Siniscalco

6. José Severo C. Pereira

A justificativa para a realização desta pesquisa era a seguinte: "a mais simples e importante contribuição, que a Psicologia tem oferecido para nortear o trabalho docente, consiste talvez na afirmação de os indivíduos possuírem características próprias, cuja consideração é básica para qualquer ação didática eficiente. Contudo, o reconhecimento da importância prática das diferenças individuais, que já adquiriu, no plano teórico, a posição do mais sovado lugar-comum, continua completamente ausente da atividade docente efetiva. (...) Foi da necessidade urgente de suprir essa deficiência que nasceu a idéia da Ficha de Observação de Alunos (FOA)"34 . O conhecimento do comportamento do aluno seria obtido através da observação realizada pelo professor, que registraria a manifestação de formas típicas de comportamento previamente estabelecidas.

\footnotetext{
${ }^{33}$ Anísio TEIXEIRA, Carta de Anísio Teixeira a Fernando de Azevedo, de 24 de outubro de 1956, Arquivo Fernando de Azevedo - IEB/USP.
} 
A FOA teria as seguintes finalidades ${ }^{35}$ :

1. Aumentar a compreensão que o professor tem de sua classe, através da percepção do tipo de personalidade de seus alunos e das formas mais frequentes de reação. Com essas informações o professor poderá utilizar-se de recursos pedagógicos para estabelecer melhores relações com seus alunos.

2. Estabelecer elementos que permitam um programa de orientação dentro da sala de aula.

3. Fazer levantamentos de situações que permitam uma ação individualizada sobre os alunos.

4. Permitir um programa de aconselhamento organizado pelo psicólogo escolar ou orientador.

5. Permitir a elaboração de pesquisas sobre formas de comportamento de crianças.

A FOA tinha a forma de um questionário com 46 proposições $^{36}$. Cada vez que as unidades de comportamento fossem produzidas, deveriam ser anotadas no local próprio, segundo as proposições apresentadas. Havia oito categorias dentro das quais as unidades de comportamento seriam agrupadas: cooperação, liderança, prepotência, auto-confiança, insegurança, submissão, competição e hostilidade.

Essas 46 proposições foram selecionadas segundo a experiência dos autores do projeto e conforme análise da literatura psicológica referente à personalidade.

O preenchimento deveria ser feito pelo professor, após o período de aulas. O tempo de preenchimento era de cerca de 15 minutos por aluno.

Durante o mês de maio de 1957, foi feito um primeiro teste do instrumento para que fosse possível verificar se as unidades de comportamento podiam efetivamente ser observadas pelos professores. As observações foram feitas pelos professores do Grupo Escolar "Pereira Barreto", na Capital, e pelas alunas (professoras primárias efetivas comissionadas) dos cursos de pós-graduação dos Instituto Feminino de Educação "Padre Anchieta", durante 10 dias. Em cada classe foram observados 2 alunos sorteados.

Os resultados desse primeiro teste sugeriram algumas modificações no instrumento: aumentar o número de alunos observados em cada classe, para obter informações mais precisas sobre a variabilidade dentro da classe; diminuir o número de dias de observação para uma semana, facilitando o trabalho do professor, uma vez que era reduzida a variabilidade do comportamento do indivíduo; e, somente trabalhar com professores que realmente estivessem

\footnotetext{
${ }^{34}$ FICHA de Observação de Alunos, Pesquisa e Planejamento, n. 2, p. 123.

${ }^{35}$ DIVISÃO DE ESTUDOS E PESQUISAS EDUCACIONAIS, Ficha de Observação de Alunos, Relatório de Atividades CRPE/SP - 1957, Arquivo Histórico do INEP, p. 13.

${ }^{36}$ A Ficha de Observação de Alunos, elaborada em 1957, encontra-se reproduzida na parte final deste trabalho (ANEXO A).
} 
dispostos a colaborar, pois observou-se que uma percentagem muito alta de questionários tiveram que ser eliminados por incorreções no preenchimento.

Um segundo teste foi realizado no mês de outubro de 1957. A amostra deveria ser composta por todas as classes de $1 .^{\circ}, 2 .^{\circ}, 3 .^{\circ}, 4 .^{\circ}$ e $5 .^{\circ}$ anos dos 10 grupos escolares escolhidos. Esses grupos escolares foram sorteados ao acaso entre os 77 de uma relação de grupos de segunda categoria (de 20 a 39 classes), da Capital de São Paulo. "Tomaram-se somente escolas dessa categoria, a fim de se evitar uma possível coincidência de unidades amostrais, pois estavam sendo realizadas outras pesquisas em grupos de 1. a categoria na Capital, na mesma época" ${ }^{\sharp 3}$. Em cada classe foram sorteados 3 alunos, com exceção das classes mistas, onde foram sorteados 4 ( 2 de cada sexo). Somente entraram no sorteio de alunos aqueles que tinham até 11 anos de idade, uma vez que a FOA destinava-se à observação de crianças.

Esse segundo teste deveria ser feito no começo de outubro, entretanto, em virtude de uma epidemia de gripe na cidade, ele foi adiado para a semana de 21 a 26 de outubro. Ao todo, foram distribuídos 802 questionários. Destes, foram utilizados $653(81,42 \%)$ e 149 foram eliminados. Os questionários eliminados estavam em branco, não foram utilizados ou não seguiram as instruções.

O trabalho com a Ficha de Observação de Alunos deveria ser complementado por testes de escolaridade que apresentassem perfis do desenvolvimento mental de cada aluno em cada matéria ensinada.

\section{Escalas de Escolaridade.}

Esta pesquisa teve início em 1957 e estava sob responsabilidade da Divisão de Estudos e Pesquisas Educacionais, contando com a participação dos seguintes pesquisadores:
1. Silvia T. Maurer
7. Pedro A. Bergamo
2. Maria da Glória C. Macruz
8. Célia A. Teixeira Marques
3. Maria do Carmo Guedes
9. Dirce Pestana
4. Maria Aparecida C. Reis
10. Álvaro Marchi
5. Otávio P. Manso Bastos
11. José Furtado Pizzani
6. Lybia de Mattos Bruno

\footnotetext{
${ }^{37}$ DIVISÃO DE ESTUDOS E PESQUISAS EDUCACIONAIS, Ficha de Observação de Alunos, Relatório de Atividades CRPE/SP - 1957, Arquivo Histórico do INEP, p. 18.
} 
O "grau de escolaridade" foi definido como sendo o "grau de realização dos alunos alcançado através do trabalho escolar durante o ano"38. Justificava-se a elaboração das Escalas de Escolaridade através do seguinte argumento: "O sistema de aprovação em vigor faz com que um aluno reprovado tenha que repetir todo o programa escolar do ano anterior, sem ser considerado o que foi aprendido. Isso poderia ser evitado, fornecendo-se ao professor informações precisar sobre os conhecimentos adquiridos pelos alunos, capazes de orientar os trabalhos docentes, permitindo maior continuidade no ensino"39.

Portanto, o objetivo do projeto era "elaborar instrumentos que forneçam informações precisas e seguras sobre o grau de conhecimento que o aluno da escola primária tem das diversas matérias lecionadas durante os quatros anos de curso" ${ }^{\text {. }}$. Esse instrumento $\operatorname{possibilitaria}^{41}$ : a) avaliar o aproveitamento de cada aluno em relação ao de sua classe, e o aproveitamento médio da classe em relação ao da população escolar primária; b) diagnosticar dificuldades individuais do aluno em relação ao conjunto de matérias constantes do programa; c) verificar o progresso de cada aluno durante o ano e durante o curso; d) verificar a relação entre o que foi aprendido e o que foi ensinado.

A elaboração preliminar da Escala de Escolaridade foi feita em $1957^{42}$, com o material obtido através dos Semanários dos professores do Grupo Escolar Alberto Torres (próximo ao CRPE), acrescido do material dos livros didáticos mais usados e dos Programas para o Ensino Primário Fundamental elaborado pela Secretaria da Educação de São Paulo. As questões formuladas constituíram as provas mensais que, no conjunto, abrangeram todo o programa oficial para o $2 .^{\circ}, 3 .^{\circ}$ e $4 .^{\circ}$ anos do curso primário. Não se formularam questões para alunos do 1. ${ }^{\circ}$ ano devido às dificuldades apresentados por alunos em fases iniciais de alfabetização. Ao todo, 660 alunos do Grupo Escolar Alberto Torres realizaram provas mensais que colaboraram na elaboração da Escala de Escolaridade.

A partir da tabulação das questões segundo acerto, erro, omissão ou dúvida, calculouse o grau de dificuldade de cada questão e as deficiências das questões e das instruções. Com isso, procurou-se aperfeiçoar as questões e as instruções e também sugeriram-se temas para pesquisas complementares que deveriam ser feitas para dar maior precisão ao instrumento:

\footnotetext{
${ }^{38}$ PROJETO de Escalas de Escolaridade, Pesquisa e Planejamento, n. 1, p. 131.

${ }^{39}$ Ibidem, p. 131.

${ }^{40}$ ESCALAS de Escolaridade, Pesquisa e Planejamento, n. 2, p. 167.

${ }^{41}$ DIVISÃO DE ESTUDOS E PESQUISAS EDUCACIONAIS, Escalas de Escolaridade, Relatório de Atividades CRPE/SP - 1957, Arquivo Histórico do INEP, p. 29.

${ }^{42}$ Ibidem, p. 30-41.
} 
estudo sobre o ensino da aritmética; estudo sobre o vocabulário do aluno da escola primária; e, elaboração de uma prova de leitura.

Em uma segunda fase de trabalho, sortearam-se ao acaso 10 Grupos Escolares de primeira categoria (com mais de 40 classes), nos quais seriam aplicadas provas semestrais de Português, para o $2 .^{\circ}, 3^{\circ}$, e $4 .^{\circ}$ anos, com a finalidade de estudar os resultados das questões quando respondidas por uma amostra da população escolar primária de São Paulo. Nessas escolas sortearam-se $10 \%$ de alunos do sexo masculino, não repetentes; $10 \%$ do sexo masculino, repetentes; $10 \%$ do sexo feminino, não repetentes; e, $10 \%$ do sexo feminino, repetentes.

As questões dessas provas foram retiradas daquelas já aplicadas no Grupo Escolar Alberto Torres. As provas do $2 .^{\circ}$ e $3 .^{\circ}$ anos tinham 50 questões e as do $4 .^{\circ}$ ano tinham 60 questões. As provas foram aplicadas por membros da equipe de pesquisadores, especialmente treinados. Ao todo, aplicaram-se 1.408 provas.

A correção das provas foi feita segundo o critério adotado de acerto, erro, omissão e dúvida. Introduziu-se uma nova tabulação segundo os erros de $27 \%$ dos alunos "superiores" e $27 \%$ dos alunos “inferiores” (Processo Simplificado de Análise de Item de Stanley).

A amostra para a aplicação de provas de Português no segundo semestre era formada por cinco Grupos Escolares sorteados dentre os que compunham a amostra do primeiro semestre, e de outros cinco sorteados entre os que não fizeram parte da amostra no primeiro semestre. As provas do segundo semestre tinham 50 questões, sendo aplicadas 1.105 provas.

Paralelamente à aplicação de provas, foram sorteados $10 \%$ dos professores de cada ano das escolas participantes para serem entrevistados. Essa entrevista visava obter suas opiniões, sugestões e críticas sobre as provas.

Os resultados obtidos no ano de 1957 referiam-se, principalmente, aos aspectos formais das questões. Também determinaram-se as técnicas de aplicação de provas e de tratamento dos dados coletados.

Em 1958, iniciou-se a construção do instrumento de medida que consistia em provas com "questões sobre todos os pontos do programa oficial e estas deveriam distribuir-se, quanto à dificuldade, dentro de uma curva normal. Cada prova deveria ter entre 50 a 60 questões, no máximo" ${ }^{\text {43 }}$. Complementando o trabalho, organizou-se um fichário de questões paralelas para renovação constante das provas.

\footnotetext{
${ }^{43}$ ESCALAS de Escolaridade, Pesquisa e Planejamento, n. 3, p. 150.
} 
A pesquisa contava com 6 aplicadores de provas e 3 auxiliares treinados. Sortearam-se 30 escolas e aplicaram-se 5.853 provas.

Em 1959, depois de terminada a coleta de dados referentes às provas de $2 .^{\circ}, 3 .^{\circ}$ e $4 .^{\circ}$ anos, retomou-se o trabalho de construções da prova para o $1 .^{\circ}$ ano.

"Os itens construídos sobre o programa, num total de 130, distribuíram-se por 6 provas (português e aritmética), que foram aplicadas em 14 grupos escolares, correspondentes a 5\% do total de grupos escolares da Capital, excetuados os cursos primários anexos e os grupos escolares de apenas uma classe de $1 .^{\circ}$ ano. Em cada um desses grupos foram sorteadas 2 classes, uma masculina e uma feminina, devendo cada aluno responder a todas as questões das 6 provas, e sendo de 3 a 4 dias o intervalo de tempo entre a aplicação de cada prova na mesma classe" 44 .

Após a aplicação dessas provas, os pesquisadores destacaram a necessidade de se realizar um estudo sobre o "vocabulário infantil", "estudo que deverá ter como objetivo primeiro o levantamento das palavras mais usadas na linguagem oral e escrita das crianças de sete a doze anos de idade" 45 .

O conhecimento mais aprofundado do vocabulário infantil permitiria a "organização de uma prova de leitura para o Curso Primário, que virá completar o conjunto de testes da Escala de Escolaridade, e também uma revisão e análise dos livros didáticos. Além disso, o estudo do vocabulário dará base para adaptação dos testes de inteligência e um conjunto de informações sobre o desenvolvimento da criança quanto à linguagem, desenvolvimento que se caracteriza pela ampliação do vocabulário para preencher as necessidades culturais e sociais que a criança vai enfrentando" 46 .

A construção de Escalas de Escolaridade para o $1 .^{\circ}$ ano não chegou a se concluir. $\mathrm{O}$ relatório do Serviço de Estatística, de 1961, apresentou as seguintes considerações sobre a análise de itens para as provas apresentadas: "As análises realizadas pelo Serviço, terminadas em setembro de 1961, dão as indicações, para cada uma das provas, do grau de dificuldades dos itens, da homogeneidade ou consistência internas de cada uma das provas, tendo-se testado também a equidistribuição ou não das alternativas de cada prova, com a finalidade de interpretar os resultados obtidos para a medida de homogeneidade. Os resultados dessa análise

\footnotetext{
${ }^{44}$ ESCALA de Escolaridade, Pesquisa e Planejamento, n. 4, p. 99.

${ }^{45}$ Ibidem, p. 100.

${ }^{46}$ Ibidem, p. 100.
} 
de itens levaram o Serviço ao parecer de que estas provas não constituíam ainda uma Escala de Escolaridade, havendo então necessidade de se construir e testar novos itens" ${ }^{\text {"47. }}$.

Para complementar os estudos a respeito da construção de Escalas de Escolaridade, a Divisão de Estudos e Pesquisas Educacionais promoveu diversas pesquisas sobre a solução de problemas em aritmética e sobre o vocabulário infantil que serão apresentadas a seguir.

\section{Estudo experimental sobre o rendimento na solução de problemas aritméticos na escola primária.}

Este estudo, iniciado em 1959, foi realizado pelos pesquisadores José Mario Pires Azanha, Frederico de Barros Brotero e Lygia Siniscalco, da Divisão de Estudos e Pesquisas Educacionais.

A justificativa para realização deste estudo foi: “O baixo rendimento em Aritmética é, dentre os problemas relacionados com o ensino primário, um dos mais generalizados e importantes. Essa importância decorre, não só da posição central que o ensino da Aritmética ocupa no conjunto das atividades curriculares da Escola Primária, como também dos efeitos que a ineficiência desse ensino produz nos cursos que se seguem ao primário. Como reflexo dessa situação, têm havido numerosos estudos destinados a localizar os fatores responsáveis pelo baixo rendimento em Aritmética. No Brasil, porém, esses estudos são escassos e pouco se tem obtido de aproveitável, dada a generalidade das abordagens e a complexidade do tema"48.

A contribuição que este estudo propunha-se a fazer no sentido de estabelecer critérios de redação e apresentação de problemas na Escola Primária era "estudar a importância que o grau de familiaridade com as situações apresentadas pode ter na solução de problemas

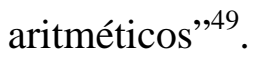

"Na primeira fase da pesquisa construiu-se um conjunto de provas para se averiguar a familiaridade dos alunos com diversas situações que envolvem três tipos de atividade: comercial, industrial e recreativa. Após a verificação-piloto dessas provas fez-se o planejamento estatístico do experimento. Selecionou-se uma amostra casual de quatro Grupos Escolares, sorteando-se, em cada um, duas classes de $2 .^{\circ}, 3 .^{\circ}$ e $4 .^{\circ}$ anos, nas quais se

\footnotetext{
${ }^{47}$ SERVIÇO DE ESTATÍSTICA, Trabalhos concluídos, Relatório de Atividades CRPE/SP - 1961, Arquivo Histórico do INEP, p. 21.

${ }^{48}$ José Mario Pires AZANHA, Frederico de Barros BROTERO e Lygia SINISCALCO, O rendimento na solução de problemas aritméticos na escola primária, Pesquisa e Planejamento, n. 4, p. 127.

${ }^{49}$ Ibidem, p. 128.
} 
aplicaram, inicialmente, as provas de familiaridade. Depois analisados os resultados, redigiram-se, em relação a cada grau, 12 problemas para cada um dos tipos de atividade, que foram aplicados na amostra selecionada" ${ }^{\natural 0}$.

A conclusão deste experimento, apesar de não ser definitiva - como ressaltam seus autores - indica que "os diferentes níveis de familiaridade com a situação são, de um modo geral, pouco importantes para o rendimento na solução de problemas" ${ }^{\sharp 1}$.

\section{Estudo experimental sobre os efeitos de alterações na forma de apresentação de problemas aritméticos.}

Realizado por José Mario Pires Azanha, Frederico de Barros Brotero e Lygia Siniscalco (da Divisão de Estudos e Pesquisas Educacionais), auxiliados pelo estatístico Álvaro Marchi, em 1960 e 1961, este estudo relacionava-se com as pesquisas a respeito da construção de Escalas de Escolaridade, na medida em que tratava de um dos aspectos da solução de problemas aritméticos na escola primária.

Os objetivos deste estudo eram: verificar se a existência de unidade entre os problemas de dado conjunto favorece sua solução; verificar se a ordem em que a pergunta aparece no problema altera o rendimento do aluno; e, verificar se a presença de unidade de assunto nos problemas tem alguma influência.

Os autores esclareciam que a definição de "unidade", quando aplicada a um conjunto de problemas, é: "um grupo de problemas constitui uma unidade, quando os diversos problemas são organizados de modo que cada um deles seja um momento numa sequência de ações visando um dado objetivo" ${ }^{, 52}$.

Os problemas formulados foram aplicados em dois grupos escolares sorteados. Em cada grupo foram escolhidas 2 classes masculinas e 2 classes femininas por grau escolar (2. ${ }^{\circ}$, $3 .^{\circ}$ e $4 .^{\circ}$ anos), o que forneceu 24 classes. Ao todo foram aplicadas 767 provas.

\footnotetext{
${ }^{50}$ DIVISÃO DE ESTUDOS E PESQUISAS EDUCACIONAIS, Atividades de Pesquisa, Relatório de Atividades do CRPE/SP - 1959, Arquivo Histórico do INEP, p. 18.

${ }^{51}$ Jose Mario Pires AZANHA, Frederico de Barros BROTERO e Lygia SINISCALCO, O rendimento na solução de problemas aritméticos na escola primária, Pesquisa e Planejamento, n. 4, p. 145.

${ }^{52}$ José Mario Pires AZANHA, Frederico de Barros BROTERO e Lygia SINISCALCO, Estudo experimental sobre os efeitos de alterações na forma de apresentação de problemas aritméticos, Pesquisa e Planejamento, n. 5, p. 191.
} 
Os resultados apresentados pelo estudo indicam que "as comparações e interações estudadas não foram significativas em nenhum grau escolar. Somente para o $3 .^{\circ}$ e $4 .^{\circ}$ graus a comparação entre sexos foi significativa" ${ }^{, 53}$.

\section{Estudo sobre o vocabulário da criança na escola primária.}

Este estudo surgiu em função da construção de Escalas de Escolaridade para o Curso Primário e tinha como objetivo determinar as palavras utilizadas com maior frequência pelas crianças da escola primária, tanto na linguagem escrita como na falada, para que fosse possível a construção de testes de leitura.

A Divisão de Estudos e Pesquisas Educacionais, dirigida por Dante Moreira Leite, foi a responsável por sua coordenação, no ano de 1959.

Para o vocabulário escrito, coligiram-se dados através de composições escritas sobre figuras, produzidas por crianças de $2 .^{\circ}, 3^{\circ}$ e $4 .^{\circ}$ anos. Também obtiveram-se palavras através de "associações controladas", em que as crianças escrevem expressões sugeridas por uma “palavra-estímulo". Foram construídas 8 listas, com 50 palavras cada ${ }^{54}$.

Para o vocabulário oral, as informações foram obtidas das através da narração de histórias pelas crianças, a partir das figuras utilizadas nas composições, e através de listas de “associações controladas". Foram coligidas cerca de 100 histórias narradas por crianças do 1 . $^{\circ}$ ao $4 .^{\circ}$ ano primário.

\section{Estudos sobre estatísticas educacionais.}

Durante a realização do Levantamento do Ensino Primário, alguns estudos a respeito da utilização de estatísticas educacionais foram feitos pelos pesquisadores da Divisão de Estudos e Pesquisas Sociais.

Joanna Mader Elazari Klein participou, em 1958, da X Reunião da Sociedade Brasileira para o Progresso da Ciência, onde apresentou uma comunicação a respeito das estatísticas educacionais publicadas no Anuário Estatístico do Brasil.

Segundo a autora, "os resultados publicados no Anuário Estatístico do Brasil apresentam-se em disposição tabular que não permite conhecer os aspectos relevantes do ensino primário. Não oferecem os elementos necessários para o conhecimento das várias

\footnotetext{
${ }^{53}$ Ibidem, p. 204.

${ }^{54}$ DIVISÃO DE ESTUDOS E PESQUISAS EDUCACIONAIS, Atividades de Pesquisa, Relatório de Atividades do CRPE/SP - 1959, Arquivo Histórico do INEP, p. 19.
} 
configurações em que se organizam os diversos componentes da realidade educacional. A grande variação que existe nas tabelas divulgadas dificulta o estudo do desenvolvimento do ensino, mesmo naqueles aspectos sobre os quais se publicam os resultados. Dessa forma, dificilmente podem ser usados para orientar a administração no estabelecimento de uma política que atenda às diferentes necessidades do sistema escolar. (...) Os dados globalizados não permitem estruturar as variáveis que compõem a realidade educacional, segundo os aspectos básicos do ensino; por isso dificultam a localização e hierarquização dos problemas apresentados pelo sistema escolar, que devem ser estudados através da pesquisa científica" ${ }^{, 55}$.

A autora exemplifica essa dificuldade de utilização dos dados disponíveis sobre a escola primária com o fato de que para conhecer as condições mais gerais do sistema escolar, o CRPE/SP foi obrigado a realizar o Levantamento do Ensino Primário em vez de se utilizar dos dados coligidos pelas agências oficiais de estatística.

Na mesma linha de pesquisa, José Fábio Barbosa da Silva fez um estudo, em 1958, sobre algumas informações coligidas pelo Departamento de Estatística do Estado de São Paulo (DEESP) com o objetivo de saber com que segurança se poderiam utilizar esses dados nas futuras investigações do Centro.

O autor comparou os dados sobre matrículas de alunos nas escolas primárias existentes no DEESP com os obtidos pelo Levantamento do Ensino Primário do CRPE/SP e concluiu: “A comparação realizada permitiu apanhar algumas das possíveis fontes de falhas desses dados, quer decorrentes do processo de coleta, quer da forma de preencher o instrumento de coleta pelo informante" 56 .

Em 1960, a revista Pesquisa e Planejamento publicou um artigo de Celso de Rui Beisiegel em que se discute o papel das estatísticas educacionais no desenvolvimento da pesquisa em educação, no sentido de analisar como tornar possível um melhor aproveitamento das informações oficiais no trabalho científico.

$\mathrm{O}$ autor destaca o fato de que o desenvolvimento quantitativo da escola e sua democratização ocorreu em detrimento da qualidade do ensino e da organização do sistema escolar. A reflexão pedagógica e a política educacional passaram a necessitar de trabalhos que oferecessem uma visão sistemática geral do ensino, indispensável para se definir a relevância de seus problemas e deficiências.

\footnotetext{
${ }^{55}$ Joanna Mader Elazari KLEIN, Estatística Educacional e Administração Escolar, Pesquisa e Planejamento, n. 3, p. 47-8.

${ }_{56}$ José Fábio Barbosa da SILVA, Fontes e falhas nas informações sobre matrícula na escola primária, Pesquisa e Planejamento, n. 3, p. 51.
} 
O uso da amostragem como técnica de levantamento de dados mostrou-se útil em função das numerosas populações que devem ser abrangidas pelos estudos sociais e educacionais. "Seu emprego reduz o número de casos estudados e diminui consideravelmente os gastos de tempo, material e pessoal. Dá também maior precisão aos resultados da pesquisa, pois ao reduzir o volume dos trabalhos torna possível realizá-los com pessoal mais habilitado e com maior rigor técnico" 57 .

O uso da amostragem, entretanto, era dificultado pela grande heterogeneidade da escola primária paulistana, que convivia com escolas com diferentes cargas horárias, diferente número de classes e diferentes instalações. Para Celso Beisiegel, o trabalho estatístico com essa heterogeneidade poderia ser resolvido através da elaboração de planos de amostragem mais elaborados que permitissem separar a população em grupos mais ou menos homogêneos e eliminaria a probabilidade de serem selecionadas apenas unidades em que se apresentassem valores extremos das variáveis.

Em relações à questão da fidedignidade das estatísticas oficiais, o autor remete-se ao estudo realizado por José Fábio Barbosa da Silva a respeito dos erros e imprecisões dos dados coligidos pelo DEESP e afirma que “o aproveitamento das informações oficiais, nestas condições, só era possível após a organização de um cadastro que reunisse as informações julgadas fidedignas de todas as escolas incluídas nas relações dos vários órgãos da Capital"58.

Em 1958, o CRPE/SP organizou um cadastro que reunia as escolas públicas estaduais (grupos escolares, escolas isoladas e cursos primários anexos), escolas públicas municipais e escolas particulares. Este cadastro seria atualizado anualmente com informações relativas ao mês de agosto, data em que a situação escolar estabilizava-se.

O autor conclui: "o cadastro foi organizado para se corrigirem falhas existentes nas informações oficiais e permitir-lhes o aproveitamento em trabalhos científicos. Sendo volumosa essa tarefa, ela só se justifica pela importância das estatísticas educacionais no desenvolvimento da pesquisa em educação, bem como na localização de problemas relativos à situação geral do sistema escolar primário. Com base nessas informações já se localizaram deficiências marcantes da escola primária, como por exemplo as deficiências de capacidade da rede, do caráter seletivo da escola e de rendimento escolar" ${ }^{\text {"59. }}$.

\footnotetext{
${ }^{57}$ Celso de Rui BEISIEGEL, Aproveitamento de estatísticas educacionais em pesquisas, Pesquisa e Planejamento, n. 4, p. 29.

${ }^{58}$ Ibidem, p. 31.

${ }^{59}$ Ibidem, p. 33.
} 


\section{Levantamento sobre o Inspetor Escolar do Estado de São Paulo.}

A pesquisa sobre o Inspetor, realizada em 1958 e 1959, surgiu como uma extensão do Levantamento do Ensino Primário realizado pela Divisão de Estudos e Pesquisas Sociais do CRPE/SP, oferecendo dados para complementar as informações sobre o pessoal docente e administrativo do ensino elementar e ampliando o quadro de informantes sobre os problemas educacionais.

Os objetivos desta pesquisa dividem-se entre dois conjuntos de temas: 1. A caracterização atualizada do Inspetor, incluindo sua formação escolar, experiência profissional e mobilidade no magistério estadual; e, 2. A opinião do Inspetor sobre alguns problemas do ensino primário, incluindo a formação profissional do inspetor, diretor e professor, dificuldades do professor e do diretor no exercício de suas funções e modificações julgadas necessárias na escola primária ${ }^{60}$.

Joanna Mader Elazari Klein, em relatório sobre essa pesquisa, informa que os dados necessários seriam coligidos por um questionário, respondido por todos os Inspetores Escolares do Estado de São Paulo que exerciam suas funções, em caráter efetivo, em setembro de 1958. Esse trabalho seria facilitado pela realização do Curso Intensivo para Inspetores Escolares pela Divisão de Aperfeiçoamento do Magistério do CRPE/SP, que proporcionaria um contato direto com cerca de 50\% dos Inspetores Escolares de São Paulo.

Dos 158 Inspetores Escolares efetivos que estavam em exercício em setembro de 1958, 151 responderam o questionário ${ }^{61}$.

O resultado da caracterização do Inspetor, em linhas gerais, foi o seguinte: "dos atuais inspetores escolares, 95\% são do sexo masculino, 99\% de cor branca e 93\% são casados. Têm entre 40 e 49 anos de idade 66\% dos inspetores. Nasceram no Interior do Estado de São Paulo $92 \%$ dos inspetores" ${ }^{\prime 2}$. O relatório também apresenta dos seguintes dados:

- Formação escolar;

- Época de conclusão do curso normal;

- Cursos feitos antes do curso normal;

- Tipo e localização da escola normal cursada;

\footnotetext{
${ }^{60}$ Joanna Mader Elazari KLEIN, O Inspetor Escolar do Estado de São Paulo, Pesquisa e Planejamento, n. 3, p. $123-4$.

${ }^{61}$ Joanna Mader Elazari KLEIN, Problemas do Ensino Primário vistos pelo Inspetor Escolar, Pesquisa e Planejamento, n. 4, p. 82.
} 
- Cursos ligados ao ensino, além do curso normal;

- Tempo de exercício da função de professor primário;

- Tempo de exercício da função de diretor;

- Tempo de exercício da função de inspetor escolar;

- Tempo de exercício da função de auxiliar de inspeção; e,

- Tempo de exercício no magistério primário estadual.

Em relação à opinião do Inspetor a respeito dos problemas do ensino primário, Joanna Mader Elazari Klein relata que o material didático disponível e a redução do período letivo diário são apontadas como principais causas de dificuldades do professor. Além disso, os Inspetores também indicaram que "a formação do professor é falha, especialmente, no que diz respeito à metodologia das diferentes matérias do currículo e se deve a poucos estágios de observação em classe de curso primário, falta de prática na direção de uma classe durante um dia letivo completo e poucas aulas práticas durante o Curso Normal, além da falta de condições para aplicar na escola primária os conhecimentos adquiridos"

Em relação aos problemas enfrentados pelos diretores de escolas, 79\% dos Inspetores acreditam que a solução seria "a existência de dois diretores nos grupos escolares: um com função apenas administrativa e outro com função apenas técnica, de orientação do ensino propriamente dito" 64 .

$\mathrm{Na}$ opinião dos Inspetores, os cursos de aprimoramento oferecidos pela Secretaria e pelo Departamento de Educação seriam a melhor forma de aprimorar a formação profissional dos Professores, Diretores e Inspetores Escolares. Outras necessidades apontadas para melhoria do ensino seriam o aumento do período letivo diário, diminuir o número de alunos por classe, mudar o sistema de promoção dos alunos e aumentar o número de anos dos cursos.

Analisando as funções exercidas pelos Inspetores Escolares ao longo da história, Joanna Mader Elazari Klein aponta a tendência de se acentuar sua função de orientador pedagógico. A autora afirma que deixando as funções exclusivamente burocráticas e colocando em prática suas potencialidades de agente orientador e introdutor de novas idéias,

\footnotetext{
${ }^{62}$ Joanna Mader Elazari KLEIN, O Inspetor Escolar do Estado de São Paulo, Pesquisa e Planejamento, n. 3, p. 131.

${ }^{63}$ Joanna Mader Elazari KLEIN, Problemas do Ensino Primário vistos pelo Inspetor Escolar, Pesquisa e Planejamento, n. 4, p. 84.

${ }^{64}$ Ibidem, p. 89.
} 
os Inspetores poderiam colaborar para a realização de um programa de reconstrução do ensino primário no Estado ${ }^{65}$.

\section{Associações de "nissei”" em São Paulo.}

Esta foi uma pesquisa financiada pelo CRPE/SP e realizada no primeiro semestre de 1957, por Ruth Correia Leite Cardoso. Seu objetivo era "compreender a importância e a atuação das associações juvenis no processo aculturativo por que passam os japoneses e seus descendentes em São Paulo",66.

Estudando o papel da família e da escola na educação dos "nissei", a autora afirma que "ao iniciarmos a investigação, verificamos a necessidade de compreender o papel da família e da escola na educação dos 'nissei', e assim explicar o porquê da manutenção ou abandono de certos padrões tradicionais japoneses. Não podíamos simplesmente identificar a escola como a única agência de transmissão de padrões ocidentais e a família como o grupo conservador, interessado apenas em manter a cultura japonesa como um todo. Vimos a velha geração de japoneses admitir comportamentos e valores das culturas ocidentais que permitiam o sucesso de seus filhos, e muitas vezes observamos a ineficiência da escola como impositora destes padrões novos, uma vez que sua ação se circunscreve aos jovens e num curto período de tempo",67.

Os resultados dessa pesquisa deveriam ter sido publicados em um volume da série de monografias do CRPE/SP, entretanto, sua publicação ocorreu em uma separata da Revista de Antropologia (vol. 7, de 1959), sob o título "O papel das associações juvenis na aculturação dos japoneses".

\section{Análise do conteúdo dos livros de leitura.}

Este estudo foi feito por Dante Moreira Leite, diretor da Divisão de Estudos e Pesquisas Educacionais, em 1959. Seu objetivo era relacionar alguns conhecimentos de psicologia ao processo educativo utilizado nos livros de leitura. Procurava-se verificar se os textos dos livros de leitura facilitavam o processo de "despertar o interesse do aluno pela leitura e dar-lhe um conhecimento da realidade social. Essa análise viria possibilitar, ainda,

\footnotetext{
${ }^{65}$ Joanna Mader Elazari KLEIN, Subsídios para um planejamento da inspeção do ensino primário, Pesquisa e Planejamento, n. 4, p. 25.

${ }^{66}$ Ruth Correia Leite CARDOSO, Associações de "nissei” em São Paulo, Pesquisa e Planejamento, n. 3, p. 154.

${ }^{67}$ Ibidem, p. 155.
} 
estudos sobre a reação dos alunos aos livros de leitura e, também, comparações com outros tipos de leitura infantis, como histórias em quadrinhos e livros de história não escolares"68.

A análise de conteúdo dos livros de leitura da escola primária foi feita a partir dos 10 livros mais adotados no Estado de São Paulo.

O autor elaborou três considerações a respeito dos livros de leitura analisados:

1. "Se procuramos uma expressão para definir o conteúdo do livro didático, talvez nos firmemos na palavra 'prosaico'. Poucos livros, com efeito, escapam desse domínio, tal a ausência de vida ou de forma literária nas suas lições. Mas essa afirmação não é verdadeira para alguns poucos livros analisados, cujos autores demonstram sensibilidade literária, ou, pelos menos, bom gosto";

2. “A outra observação importante refere-se às grandes diferenças entre os livros quanto ao conteúdo, de tal forma que alguns livros não podem despertar ou satisfazer o interesse por histórias, enquanto outros não fazem referência a ciências naturais"; e,

3. "Enfim, os livros didáticos apresentam uma concepção muito limitada dos interesses e da capacidade intelectual das crianças, limitando-se a lições muito pobres, quanto ao conteúdo, embora muito ricas quanto a um suposto desenvolvimento do vocabulário"69.

Jorge Nagle, ao apresentar as produções de Dante Moreira Leite ligadas ao campo da educação, considera este trabalho como sendo aquele em que a análise do livro de leitura “integra-se ampla e definitivamente num quadro que envolve a literatura infantil e a literatura em geral" ${ }^{, 70}$. Neste trabalho, segundo Jorge Nagle, Dante Moreira Leite consegue tanto enriquecer os esquemas teóricos existentes, através de sua crítica, como analisar os livros didáticos a partir de novos princípios e critérios.

\section{Ocupação dos pais dos candidatos às escolas industriais na cidade de São Paulo.}

Este levantamento foi realizado por Moysés Brejon, da Divisão de Estudos e Pesquisas Sociais, em 1961.

A justificativa para o estudo da ocupação dos pais dos candidatos às escolas industriais de São Paulo é que a ocupação de um indivíduo, assim como sua renda e sua educação são importantes fatores para determinar a diferenciação das classes sociais. $\mathrm{O}$ autor preocupa-se

\footnotetext{
${ }^{68}$ DIVISÃO DE ESTUDOS E PESQUISAS EDUCACIONAIS, Conteúdo dos livros de leitura para a escola primária, Relatório de Atividades CRPE/SP - 1958, Arquivo Histórico do INEP, p. 18.

${ }^{69}$ Dante Moreira LEITE, Análise de conteúdo dos livros de leitura da escola primária, Pesquisa e Planejamento, n. 4 , p. $125-6$.
} 
com a elaboração de escalas ocupacionais como fatores de identificação social que poderiam ser utilizadas em pesquisas sociais. Assim, ao levantar a ocupação dos pais dos candidatos, ele obteria uma fonte para sua caracterização sócio-econômica.

De acordo com essa pesquisa, as escolas industriais da cidade de São Paulo "são procuradas por candidatos cujos pais, na sua grade maioria, pertencem a classe de modesta condição sócio-econômica, quando considerados em relação à ocupação que exercem"71 .

$\mathrm{O}$ autor compara os dados obtidos junto às escolas industriais com os dados relativos aos ginásios e encontra uma situação bastante diferente: “os indivíduos cujos pais exercem profissões que gozam tradicionalmente de grande prestígio social, procuram o curso ginasial em proporção significativamente maior do que o industrial" ${ }^{, 72}$.

Como conclusão, o autor sugere a distribuição de bolsas de estudos aos jovens das escolas industriais, a fim de atrair um número maior de interessados e diminuir a sua evasão escolar.

\section{Estudo sobre a promoção automática na escola primária.}

Em palestra proferida no dia 30 de maio de 1961, na cidade de Santos (SP), Elsa Lima Gonçalves Antunha relatou sua experiência no planejamento e condução do sistema de promoção automática no Grupo Escolar Experimental mantido pela Secretaria da Educação do Estado de São Paulo. Nesta escola, deste 1959, adotava-se esse sistema a pedido do Prof. Luiz Contier e do Dr. Carlos Pasquale (ex-diretores do Departamento de Educação). Pretendia-se, a partir desta experiência, estender o regime de promoção automática para toda a rede estadual paulista de ensino primário.

A autora lembrou que o interesse pela experiência da adoção da promoção automática surgiu em setembro de 1956, quando Almeida Júnior o defendeu em uma conferência em Ribeirão Preto (SP), no I Congresso Estadual de Educação.

Em vez de utilizar-se da expressão 'promoção automática', na experiência paulista, utilizou-se a expressão ‘promoção por rendimento efetivo' (sugestão de José Querino Ribeiro da FFCL/USP), desejando com isto significar que a passagem da criança de um ano a outro se

\footnotetext{
${ }^{70}$ Jorge NAGLE, A reflexão pedagógica crítica: uma necessidade e um exemplo, Cadernos de Pesquisa, n. 17, p. 16.

${ }^{71}$ Moyses BREJON, A ocupação dos pais dos candidatos às escolas industriais na cidade de São Paulo, Pesquisa e Planejamento, n. 5, p. 83.

${ }^{72}$ Ibidem, p. 84.
} 
faz mediante o critério da idade cronológica e que a sua localização em "grupos-classe" se faz mediante o critério de suas reais possibilidades de aprendizagem.

Segundo a autora, a adoção do sistema de promoção automática não levaria a uma diminuição dos gastos em educação. "A ênfase deve ser dada à eliminação dos entraves que limitam o rendimento da escola primária brasileira e lhe dão seu atual caráter seletivo e competitivo. Refiro-me à necessidade de programas de construções escolares, de abolição de turnos, de distribuição de material didático, de modernização de métodos e currículos, de aperfeiçoamento de professores, de maiores níveis de exigências, de aumento do sentimento de responsabilidade por parte das próprias crianças, de orientação aos pais, etc. (...) Em uma escola com todas estas condições, não poderia haver causas, a não ser circunstanciais, para o baixo rendimento, e portanto para a reprovação"73.

\section{Estudo piloto de uma escola secundária.}

A Divisão de Estudos e Pesquisas Sociais desenvolveu, em 1959, um "estudo-piloto" em que procurou analisar a adoção de novas técnicas pedagógicas em uma Escola Normal.

Essa experiência ocorreu no Colégio de Aplicação da FFCL/USP, onde "o interesse pela renovação pedagógica e pela experimentação [um dos elementos do planejamento integral] levou à criação de uma escola, de nível secundário, para funcionar como uma espécie de laboratório, onde se fundem os objetivos de experimentar novas técnicas pedagógicas e de treinar os universitários que se destinam ao magistério secundário e normal”74.

Os autores indicam que aconteceram problemas tanto do lado dos cientistas e técnicos colaboradores, quanto do lado dos alunos que passavam pela experiência.

Para os cientistas e técnicos colaboradores havia a possibilidade de relacionar a educação e as ciência sociais no sentido de encontrar soluções para os problemas práticos. Essa atividade deveria desempenhar uma importante função educativa, uma vez que exigiria o treinamento em trabalho de equipe e a tomada de consciência, pelos participantes do projeto, do papel fundamental da colaboração entre diferentes especialistas. Entretanto, não se previram as condições que deveriam preencher o pessoal técnico, auxiliar e os futuros alunos, e outras resultantes da condição específica de uma escola experimental, o que gerou problemas.

\footnotetext{
${ }^{73}$ Elsa Lima Gonçalves ANTUNHA, Promoção automática na escola primária, Pesquisa e Planejamento, n. 5, p. 104.

${ }^{74}$ Haydée Maria ROVERATTI e José Fábio Barbosa da SILVA, Experiência de técnicas modernas numa escola tradicional, Pesquisa e Planejamento, n. 4, p. 38.
} 
Para os alunos, havia a larga aplicação de uma série de atividades paralelas às aulas obrigatórias (atividades extracurriculares), que tinham o papel de completar a sua formação escolar. Entretanto, na escola experimental, essas atividades extracurriculares não eram obrigatórias, delas participando apelas os alunos que obtinham notas baixas nas atividades de classe.

Os autores avaliam esse problema da seguinte forma: "as atividades extracurriculares nos Estados Unidos constituem parte das atividades obrigatórias da escola e são intensamente exploradas nas suas possibilidades educativas. Entre nós, essas atividades tomaram sentido diverso, pois o ensino manteve, de certa forma, os seus padrões e técnicas tradicionais, aos quais se superpuseram essas técnicas modernas. Isto resultou em existência de atividades que se acrescentaram, sem que se integrassem funcionalmente, no sistema educacional brasileiro e que perdem seu caráter pedagógico na medida em que sua introdução não foi precedida de um plano que as sistematizasse, tendo em vista o seu papel no processo educativo"75.

Observou-se, portanto, que a participação do aluno nas atividades extracurriculares não se refletiu nos resultados de sua vida escolar. "Ainda mais, revela que a introdução de atividades extracurriculares nessa escola de estrutura tradicional se fez acompanhar de sérios problemas de disciplina, o que sugere a conclusão de que essas atividades, embora não tenham interferido diretamente na vida escolar do aluno, elas o fizeram indiretamente, pela alteração dos padrões de disciplina, que não foi aceita pelos dirigentes da escola ou, pelo menos, prevista" $" 76$.

Conclui-se, que essas atividades "não estavam preenchendo suas reais finalidades na esfera da educação formal, isto é, proceder à educação integral do jovem, unindo transmissão sistemática e assistemática de cultura. (...)Confirmar essa observação é concluir que a escola está se desviando de seus objetivos principais, quer como agência de educação, quer como instrumento de experimentação para posteriores renovações pedagógicas" ${ }^{\text {"77. }}$.

\section{Planejamento da expansão da rede escolar primária de Presidente Prudente.}

A Divisão de Estudos e Pesquisas Sociais iniciou em outubro de 1958 o desenvolvimento de um projeto que colaboraria com o Governo do Estado para o

\footnotetext{
${ }^{75}$ Ibidem, p. 40-1.

${ }^{76}$ DIVISÃO DE ESTUDOS E PESQUISAS SOCIAIS, Relatório de Atividades CRPE/SP - 1959, Arquivo Histórico do INEP, p. 21.

${ }^{77}$ Haydée Maria ROVERATTI e José Fábio Barbosa da SILVA, Experiência de técnicas modernas numa escola tradicional, Pesquisa e Planejamento, n. 4, p. 42.
} 
planejamento da expansão da rede escolar primária do município de São Paulo e de oito municípios do interior.

Entretanto, como não foi efetivado o convênio entre o INEP e o Governo Estadual, esse planejamento restringiu-se a alguns levantamentos feitos nas cidades de Presidente Prudente, de Santos e na Capital. Os estudos sobre Santos e sobre o município de São Paulo serão apresentados nas partes seguintes deste trabalho.

No mesmo período em que a Divisão de Estudos e Pesquisas Sociais planejou a realização do estudo em Presidente Prudente, a Divisão de Aperfeiçoamento do Magistério realizou uma "Missão Cultural" nessa cidade, da qual participaram os alunos e professores do CEEAL, no período de 26 a 31 de maio de 1958. "Essas Missões teriam a finalidade de focalizar problemas que, sendo reais para os professores, os fizessem pensar e lhes dessem oportunidades para analisar e confrontar experiências e, em seguida, desenvolver em cada um a capacidade de síntese" ${ }^{, 78}$.

Em Presidente Prudente, para se definir a localização das novas unidades escolares, seria realizado um Levantamento das escolas existentes e um censo da população em idade escolar. Os questionários foram aplicados mas, devido às restrições orçamentárias da Divisão e à falta de pessoal, a pesquisa foi suspensa e retomada somente em 1960, quando trabalhouse apenas com os dados do Censo. Utilizaram-se os dados do Censo referentes à população em idade escolar e profissões das famílias da cidade ${ }^{79}$.

Essa pesquisa seria novamente suspensa e retomada, a pedido da Delegacia de Ensino de Presidente Prudente, em outubro de 1961, tendo como responsável o Prof. Nadir de Almeida Barreto, do Serviço de Estatística. O Serviço de Estatística passou a realizar estimativas com os dados que haviam sido coletados em $1958^{80}$.

Com a retomada dessa pesquisa e análise estatística dos dados coletados, foi possível a realização de mais dois estudos, a partir de $1960^{81}$ : "Estudo sobre a estrutura familiar de Presidente Prudente", desenvolvido pela Prof ${ }^{a}$. Ruth C. Leite Cardoso; e, "Informações sobre o menor em idade escolar de Presidente Prudente", desenvolvido pelas professoras Ruth Cardoso e Armenuhy Kahvegian. Ambos deveriam ser concluídos em 1962.

\footnotetext{
${ }^{78}$ DIVISÃO DE APERFEIÇOAMENTO DO MAGISTÉRIO, Missão Cultural em Presidente Prudente, Relatório de Atividades CRPE/SP - 1958, Arquivo Histórico do INEP, p. 28.

${ }^{79}$ DIVISÃO DE ESTUDOS E PESQUISAS SOCIAIS, Planejamento da Extensão da Rede Escolar Primária de Presidente Prudente, Relatório de Atividades do CRPE/SP -1956/1960, Arquivo Histórico do INEP, p. 21.

${ }^{80}$ SERVIÇO DE ESTATÍSTICA, Levantamento das Necessidades de Expansão da Rede Escolar Primária de Presidente Prudente, Relatório de Atividades do CRPE/SP - 1961, Arquivo Histórico do INEP, p. 22.

${ }^{81}$ Ibidem, p. 23.
} 


\section{Colaboração na “Campanha pela instrução primária na cidade de Santos”.}

Em 1961, um jornal da cidade de Santos ("A Tribuna") lançou a "Campanha pela instrução primária da cidade de Santos", cujo objetivo era fazer uma análise da conjuntura escolar da cidade para que fosse possível a realização de reformas que superassem as deficiências da rede educacional, sobretudo no que se refere ao fenômeno da evasão escolar que, segundo as autoridades educacionais, atingia proporções alarmantes.

A Delegacia Regional de Ensino de Santos forneceu à Divisão de Estudos e Pesquisas Sociais (DEPS) informações sobre matrícula, movimento de alunos e aproveitamento escolar em todas as escolas do município. O objetivo da pesquisa que a DEPS desenvolveria era “definir as variáveis do fenômeno evasão escolar, a fim de que fosse possível verificar, com objetividade, a sua manifestação, intensidade, fatores e consequências" ${ }^{\prime 2}$.

Ainda em 1961, as Divisões de Estudos e Pesquisas Educacionais e de Estudos e Pesquisas Sociais (DEPE e DEPS) desenvolveram duas pesquisas em conjunto que se relacionavam à realidade escolar do município de Santos.

A primeira delas, "O professor em relação às inovações no campo da educação", tinha como objetivo "definir e caracterizar os grupo social formado pelos agentes pedagógicos, dada a sua interferência em qualquer inovação do campo educacional. Os aspectos que se colocam para essa caracterização são aqueles ligados à formação, experiência profissional, carreira no magistério, atitudes e opinião a respeito da escola primária"83. As informações para essa pesquisa foram obtidas através de questionários e formulários respondidos por professores, diretores e auxiliares de direção das escolas oficiais e particulares do município de Santos. Pretendia-se concluir essa pesquisa em 1962.

"Necessidades da rede escolar primária no município de Santos" ${ }^{\text {"4 }}$ era a segunda pesquisa a ser realizada. Esta pesquisa foi desencadeada pela "Campanha pela instrução primária de Santos" e buscava conhecer os prédios escolares da cidade e sua capacidade de atender à demanda da população por educação. O levantamento das condições da rede escolar primária se fez através de questionários e formulários aplicados nas repartições administrativas e nas escolas primárias oficiais e particulares. Também foi realizado um censo educacional, abrangendo menores de 0 a 16 anos, com informações sobre o grau de instrução,

\footnotetext{
${ }^{82}$ DIVISÃO DE ESTUDOS E PESQUISAS SOCIAIS, Evasão Escolar no Ensino Primário, Relatório de Atividades do CRPE/SP - 1961, Arquivo Histórico do INEP, p. 12.

${ }^{83}$ Ibidem, p. 18.

${ }^{84}$ Ibidem, p. 19.
} 
ocupação e motivos pelos quais não frequentou a escola em 1961, além de dados sobre o número de pessoas na família, sua renda e localização. A análise desses dados permitiu a realização de uma previsão das necessidades para atender a população em idade escolar, construção de prédios escolares e pagamento de salários "não irrisórios" aos professores. O relatório final dessa pesquisa deveria estar concluído em 1962.

\section{Levantamento da rede escolar da cidade de São Paulo.}

Em 1961, três trabalhos desenvolvidos no CRPE trataram de aspectos da escolaridade na cidade de São Paulo:

1. Cadastro escolar no município de São Paulo ${ }^{85}$. Como não havia condições para a realização de um recenseamento de escolas da cidade de São Paulo, a Divisão de Estudos e Pesquisas Sociais procurou conhecer o número de escolas existentes através do levantamento e da comparação dos arquivos das Delegacias de Ensino, do Serviço de Cadastro Escolar, do Departamento de Ensino do Estado, no SESI e das próprias escolas. Em 1958, já havia sido apresentada a idéia de criação de um cadastro de escolas públicas estaduais, escolas públicas municipais e escolas particulares existentes na cidade de São Paulo, que seria atualizado anualmente e serviria para corrigir falhas nas informações oficiais, permitindo a utilização desses dados em trabalhos científicos ${ }^{86}$. Da mesma forma que o cadastro proposto em 1958, este cadastro serviria para a correção de falhas existentes nas informações oficiais e utilizar as informações em trabalhos científicos.

2. Levantamento do Ensino Municipal da cidade de São Paulo ${ }^{87}$. Trabalho realizado pela Divisão de Estudos e Pesquisas Educacionais por solicitação da Secretaria de Educação da Prefeitura de São Paulo. Seus objetivos eram: conhecer a situação do ensino primário municipal em todos os seus aspectos; propor medidas para a organização racional de seu funcionamento; e, propor soluções para melhorar, sem ampliar, essa rede de escolas.

3. Pesquisa sobre extensão de escolaridade no município de São Paulo ${ }^{88}$. O Prof. Nelson Rosamilha, da DEPE, solicitou ao Serviço de Estatística a realização de uma estimativa

\footnotetext{
${ }^{85}$ DIVISÃO DE ESTUDOS E PESQUISAS SOCIAIS, Cadastro escolar no município de São Paulo, Relatório de Atividades do CRPE/SP - 1961, Arquivo Histórico do INEP, p.15-6.

${ }^{86}$ Trata-se do artigo de Celso de Rui BEISIEGEL apresentado no item n. ${ }^{\circ} 8$ deste relatório: Aproveitamento de estatísticas educacionais em pesquisas, Pesquisa e Planejamento, n. 4, p. 27-35.

${ }^{87}$ DIVISÃO DE ESTUDOS E PESQUISAS EDUCACIONAIS, Trabalhos realizados em 1961, Relatório de Atividades CRPE/SP - 1961, Arquivo Histórico do INEP, p. 08-9.

${ }^{88}$ SERVIÇO DE ESTATÍSTICA, Trabalhos concluídos, Relatório de Atividades CRPE/SP - 1961, Arquivo Histórico do INEP, p. 22.
} 
para o crescimento da matrícula para os $4 .^{\circ}$ e $5 .^{\circ}$ anos do curso primário do Município de São Paulo, para uma pesquisa sobre a possibilidade de extensão da escolaridade.

\section{Política e Expansão da Rede Escolar do Estado de São Paulo.}

Em abril de 1960, a Divisão de Estudos e Pesquisas Sociais elaborou um plano de estudo a respeito sobre expansão escolar no Estado, sob a responsabilidade de Francisco Weffort. Este plano foi interrompido e retomado no final de 1961, tendo Celso de Rui Beisiegel como responsável e Lindo Fava como consultor estatístico.

A finalidade desse trabalho seria a verificação da racionalidade existente no processo de expansão da rede escolar do Estado. A primeira fase da pesquisa consistiria em um levantamento dos projetos de criação de ginásios no Estado de São Paulo e os motivos que levaram à sua aprovação ou não. Este estudo, entretanto, somente teria continuidade em 1962.

Outro trabalho que colaboraria no estudo da expansão da rede escolar do Estado foi o "Estudo da distribuição, por idade e série, dos alunos matriculados no curso primário oficial do Estado de São Paulo"89, realizado pelo Serviço de Estatística do Centro, em 1961. Os dados para esse levantamento seriam fornecidos por 1.500 questionários sobre matrículas nos Grupos Escolares do Estado, relativas ao ano de 1960.

\section{Considerações Gerais.}

O principal objetivo dos levantamentos, pesquisas e estudos realizados pelo CRPE/SP, no período de 1956 a 1961, era obter informações que caracterizassem o Ensino Primário no Estado de São Paulo.

A atenção se concentrou no Ensino Primário porque este era o nível de ensino que estava sob responsabilidade estadual e onde se pretendia iniciar o processo de renovação educacional paulista. Com o andamento das pesquisas, o campo de estudo foi se cirsunscrevendo à Capital do Estado, em função das restrições orçamentárias e de pessoal e da maior facilidade de acesso à população concentrada nessa cidade.

O Levantamento do Ensino Primário foi o principal trabalho desenvolvido pelo Centro no período, sendo que a maioria das outras pesquisas serviam, basicamente, para 
complementá-lo. Este levantamento surgiu em função da insuficiência de informações oficiais sobre a escola primária da época. Pretendia-se elaborar um plano de expansão da rede escolar primária no Estado de São Paulo, mas faltavam dados confiáveis para que isso pudesse se realizar. Também existiam planos do governo federal de se ampliar o número de anos do ensino primário, de 4 para 6 anos, e havia a necessidade de se verificar a viabilidade desse projeto nas condições existentes no momento.

As estatísticas oficiais do Departamento de Estatística (DEESP) e da Secretaria da Educação do Estado não eram consideradas suficientes ou confiáveis, fato que se confirmou com a comparação dessas estatísticas com alguns resultados do Levantamento realizado pelo Centro.

A idéia que norteava as pesquisas desenvolvidas no CRPE/SP, no período de 1956 a 1961, pode ser encontrada em um dos primeiros artigos publicados na revista Pesquisa e Planejamento, no qual defendia-se o propósito de "inaugurar uma época em que o empirismo, a improvisação e a superficialidade cedam afinal o lugar ao espírito e aos métodos científicos no estudo dos problemas da educação. Como sistema organizado de transmissão da cultura e como técnica social, a educação que persistia em desenvolver-se entre nós fora do campo de atração em que incide o poder renovador das ciências passaria a beneficiar-se do espírito crítico e experimental. É, por certo, no mundo pedagógico, uma pequena revolução, que se pensa fazer, e será maior, se se conseguir levá-la até as camadas governamentais, despertando a consciência da necessidade de apoiarem em estudos objetivos seus planos de reforma" ${ }^{\text {. }}$.

Uma avaliação geral das pesquisas realizadas pelo CRPE/SP, no período estudado, pode ser obtida pela observação do seguinte quadro, no qual o ano de referência corresponde à data do início da pesquisa:

\begin{tabular}{|l|l|l|l|l|l|}
\hline Ano & $\begin{array}{l}\text { Pesquisas } \\
\text { publicadas }\end{array}$ & $\begin{array}{l}\text { Pesquisas } \\
\text { concluídas e não } \\
\text { publicadas }\end{array}$ & $\begin{array}{l}\text { Pesquisas não } \\
\text { concluídas ou } \\
\text { sem dados }\end{array}$ & $\begin{array}{l}\text { Pesquisas não } \\
\text { iniciadas }\end{array}$ & $\begin{array}{l}\text { Pesquisas sem } \\
\text { dados sobre } \\
\text { realização }\end{array}$ \\
\hline 1956 & 2 & 1 & 2 & 1 & - \\
\hline 1957 & 1 & 1 & - & 1 & 4 \\
\hline 1958 & 3 & 1 & 1 & - & - \\
\hline 1959 & 1 & 1 & - & - & - \\
\hline 1960 & - & - & 1 & - & 1 \\
\hline 1961 & 8 & - & 5 & - & 8 \\
\hline
\end{tabular}

Fonte: REGISTRO das atividades de Pesquisa - 1956-1973, Pesquisa e Planejamento, n. 16, p. 181-203.

\footnotetext{
${ }^{89}$ Ibidem, p. 24.

${ }^{90}$ [Fernando de AZEVEDO], Apresentação, Pesquisa e Planejamento, n. 1, p. 01.
} 
As pesquisas não iniciadas referem-se a uma pesquisa proposta por Frank Perry Goldman, sobre um plano de educação de grupo e recuperação humana dos índios guarani do litoral sul e uma pesquisa sobre educação no Estado de São Paulo, no período de 1932 a 1957. Nesse item também pode ser incluída a Ficha de Observação de Professores que fazia parte do projeto da Ficha de Observação de Alunos.

As pesquisas não concluídas ou sem dados sobre sua conclusão referem-se, em sua maioria, a pesquisas iniciadas em 1961 (muitas pesquisas iniciaram-se neste ano, quando o Centro estava mudando sua estrutura organizacional e seu modo de trabalho). Outras duas pesquisas incluídas nesse item são de 1956. Uma era o levantamento proposto pela DEPS sobre o Ensino Normal do Estado, que foi abandonado pela insuficiência de recursos do Centro para sustentar dois levantamentos ao mesmo tempo (o Levantamento do Ensino Primário estava sendo realizado) e por existir a pesquisa da Prof ${ }^{a}$. Maria José Garcia Werebe sobre o Ensino Secundário e Normal do Estado de São Paulo, que estava sendo financiada pelo Centro. Outra era um estudo descritivo dos principais característicos e necessidades dos adolescentes do município de São Paulo. As demais pesquisas incluídas nesse item são: Levantamento do Ensino de Presidente Prudente (1958) e o Planejamento da Expansão da Rede Escolar Primária de Santos (1960).

No item sobre pesquisas sem dados sobre realização, incluem-se várias iniciadas em 1961 e as seguintes:

- O ajustamento das crianças de ambientes estrangeiros nas escolas brasileiras (1957);

- A escola estadual e a escola municipal de uma comunidade próxima a São Paulo (1957);

- A escola japonesa em São Paulo (1957);

- O psico-diagnóstico de Rorschard aplicado às crianças de idade pré-escolar (1957); e, - Levantamento dos recursos audiovisuais existentes no município de São Paulo (1960).

O principal motivo que justificava o abandono das pesquisas, conforme os relatórios anuais de atividades do Centro, era a carência de recursos financeiros e de pessoal. Além disso, observa-se que a maioria dos levantamentos realizados, inclusive o Levantamento do Ensino Primário, não chegaram a se concluir ou a passar à uma fase de análise mais aprofundada dos dados coligidos.

Uma reclamação característica dos primeiros anos de atividades do Centro refere-se à falta de colaboração da Secretaria de Educação do Estado de São Paulo em oferecer recursos humanos e materiais para a realização das pesquisas. O Levantamento do Ensino Primário teve que ser reelaborado, restringindo-se objetivos e a amostra da população a ser pesquisada. 
A Secretaria da Educação afirmava que os dados que seriam coletados já existiam no Departamento de Estatística do Estado, por outro lado, os técnicos do CRPE duvidavam da fidedignidade desses dados.

O relatório de atividades de 1959 aponta os sérios problemas enfrentados pelas Divisões de Pesquisas. Acusa-se a supressão de uma verba federal suplementar que seria destinada à expansão do setor de pesquisas. Outra reclamação refere-se à carência de pessoal. A DEPS contava com apenas 8 pesquisadores, sendo obrigada a concentrar todos os seus esforços na realização do Levantamento do Ensino Primário, as demais pesquisas da Divisão eram reduzidas ou abandonadas.

Em 1960, Renato Jardim Moreira (Diretor da DEPS) encaminhou à Fernando de Azevedo uma carta apontando as dificuldades que o Centro atravessava. Nela, o autor destaca a existência de uma desarticulação dos grupos de pesquisa do Centro e aponta a necessidade de remodelação de suas atividades para superar o impasse vivido. O diretor da Divisão de Estudos e Pesquisas Sociais fez as seguintes sugestões ${ }^{91}$ : 1 . Reexaminar a dependência do Centro em relação ao Governo Federal, visto que era necessário encontrar fontes suplementares de recursos a fim de manter e desenvolver as atividades de pesquisa, através de acordos com instituições ou grupos interessados em obter a colaboração do Centro; 2. Estabelecer um programa de pesquisa tendo em vista orientar de modo seguro e consequente a organização do trabalho técnico e, ao mesmo tempo, fornecer um padrão para o exame das propostas de colaboração que, conforme as necessidades apontadas no item anterior, precisam ser incorporadas às atividades regulares do Centro; 3. Conceder maior autonomia de decisões ao Diretor de Divisão; e, 4. Conceder autonomia administrativa com relação aos assuntos internos da Divisão, em relação à hierarquia de funções, definição do regime de trabalho, dotação de verbas específicas à Divisão, aperfeiçoamento de pessoal e subordinação apenas à Diretoria Geral.

Na mesma época - maio de 1960 - o pessoal técnico do Centro elaborou um relatório que, acompanhado de uma carta que manifestava solidariedade ao diretor Renato Jardim Moreira, apontava o distanciamento das atividades do Centro em relação aos propósitos iniciais da instituição: "investigar a realidade social e educacional"92. Neste relatório, o principal problema apontado é a impossibilidade de se organizar um programa de pesquisa

\footnotetext{
${ }^{91}$ Renato Jardim MOREIRA, Carta de Renato Jardim Moreira a Fernando de Azevedo, de 18 de maio de 1960 , Arquivo Fernando de Azevedo - IEB/USP.

${ }^{92}$ RELATÓRIO do pessoal técnico do CRPE/SP apresentado à Fernando de Azevedo, de 21 de maio de 1960. Arquivo Fernando de Azevedo - IEB/USP.
} 
que funcionasse a longo prazo, coordenando todos os esforços no sentido de atingir os objetivos previstos. Para os técnicos que elaboraram o relatório, este problema ocorria porque os objetivos do Centro não eram claros, devido ao "divórcio existente entre a direção e o corpo técnico e ao isolamento do CRPE em relação a todas as outras instituições ligadas à política e à administração educacionais" "93. Além disso, outros problemas são apontados: grande mobilidade de pessoal técnico, falta de hierarquia de funções, ausência de critérios para promoção e falta de um programa de aperfeiçoamento do pessoal técnico.

\footnotetext{
${ }^{93}$ Ibidem, p. 01.
} 


\section{Capítulo 4 - Outras atividades da Divisão de Aperfeiçoamento do Magistério.}

A Divisão de Aperfeiçoamento do Magistério foi criada em 1957, em função da necessidade de organização dos Cursos de Especialistas em Educação para a América Latina.

Esta Divisão não promovia apenas os cursos e seminários apresentados no Capítulo 2 deste trabalho. A DAM também era responsável pelo desenvolvimento de outras atividades que envolviam, principalmente, as Classes Experimentais e o Serviço de Recursos Audiovisuais. Além disso, esta Divisão era encarregada da organização de alguns processos seletivos para professores e bolsistas.

Durante o período estudado por este trabalho, a Divisão de Aperfeiçoamento do Magistério teve dois Diretores: Joel Martins - de 1957 a 1959 - e Heládio César Gonçalves Antunha - a partir de 1960.

\section{Classes Experimentais.}

No plano de atividades da DAM existia o projeto de criação de uma Escola Experimental. Este projeto pretendia fazer "o planejamento e organização de uma escola primária considerada ideal dentro de um plano filosófico de educação preestabelecido e, ainda, de acordo com a realidade nacional"'. O responsável pelo projeto era Jorge Nagle, professor de Educação do Instituto de Educação "Padre Anchieta”, em São Paulo.

Esta escola deveria servir de modelo, caso o Estado se interessasse pela reforma, renovação e reorganização de suas escolas. A Escola Experimental também deveria desempenhar o papel de Escola de Demonstração, sendo um laboratório para aplicação de novas técnicas e métodos de ensino. Os alunos dos Cursos de Especialistas em Educação, estudantes de escolas Normais, Faculdades de Filosofia e membros do magistério estadual poderiam utilizar a Escola Experimental como "campo de observação".

Em 1959, o funcionamento de classes experimentais foi autorizado pelo Ofício GS861, de 26 de fevereiro, do Secretário de Educação do Estado. Foram implantadas duas classes, com 25 alunos por classe.

O plano de trabalho foi elaborado por orientadores com especialização na Universidade de Indiana, nos Estados Unidos: Sylvia Alves (Supervisão e Linguagem), Celso João Ferretti (Arte infantil e Estudos Sociais), Maria Aparecida Pinto (Aritmética e Música),

\footnotetext{
${ }^{1}$ DIVISÃO DE APERFEIÇOAMENTO DO MAGISTÉRIO, Escolas Experimentais, Relatório de Atividades do CRPE/SP - 1957, Arquivo Histórico do INEP, p. 46.
} 
Adla Neme (Aritmética) e Tereza Coletto (Estudos Sociais e Ciências). Dois professores primários foram selecionados para trabalhar nas classes: Leonie da Fonseca Fernandes e Olga Bellocchi Vaz Pereira.

O Relatório de Atividades do CRPE, de 1959, indica que "o trabalho realizado nas duas classes, baseando-se nos programas vigentes para o ensino elementar estadual, teve ampla repercussão nos meios educacionais do Estado e foi muito prestigiado pelas famílias das crianças"2. As Classes Experimentais receberam, neste ano, 241 visitantes e 50 estagiários.

Em 1960, prosseguiram os trabalhos com a criação de mais uma classe de primeiro ano (Prof ${ }^{a}$. Nidia Nacib Iunes) e o recebimento de 211 visitantes e 70 estagiários $^{3}$.

Em 1961, as Classes Experimentais se tornaram independentes da Divisão de Aperfeiçoamento do Magistério, com a Prof ${ }^{a}$. Sylvia Alves como responsável. Já existiam quatro classes em funcionamento (uma de $1 .^{\circ}$ ano, uma de $2 .^{\circ}$ e duas de $3 .^{\circ}$ ano). Ao todo, 97 alunos frequentavam as aulas ${ }^{4}$. Em fevereiro deste ano, houve uma nova seleção para contratação de professores, sendo contratadas Rosali Blasbalg, Adele Martuscelli e Priscila Pezzuti.

Manteve-se, para aplicação nas classes, o programa oficial de ensino do Estado de São Paulo, com ligeiras alterações constatadas como necessárias.

O trabalho dos orientadores (Adla Neme, Celso João Ferreti e Sylvia Alves) se intensificou em 1961, através de sua atuação junto aos professores que regiam as classes, com os bolsistas do CEEAL, com outros professores e junto ao Departamento de Educação. Ato todo 1.012 pessoas visitaram a escola e 71 estagiários foram recebidos.

\section{Serviço de Recursos Audiovisuais.}

Desde 1957, o CRPE/SP, através da Divisão de Aperfeiçoamento do Magistério, planejava a criação de um Serviço de Recursos Audiovisuais. Com essa finalidade o professor do Grupo Escolar Alberto Torres, Genésio Flores, foi para os Estados Unidos realizar um estágio sobre a organização de centros audiovisuais.

\footnotetext{
${ }^{2}$ DIVISÃO DE APERFEIÇOAMENTO DO MAGISTÉRIO, Classes-Laboratório, Relatório de Atividades do CRPE/SP - 1959, Arquivo Histórico do INEP, p. 25.

${ }^{3}$ DIVISÃO DE APERFEIÇOAMENTO DO MAGISTÉRIO, Classes Experimentais, Relatório de Atividades do CRPE/SP - 1956-60, Arquivo Histórico do INEP, p.33.

${ }^{4}$ CLASSES EXPERIMENTAIS, Relatório de Atividades do CRPE/SP - 1961, Arquivo Histórico do INEP, p.349.
} 
Entretanto, somente em 1959, através de um convênio assinado entre a UNESCO e o Ponto IV, este Serviço foi criado, com o objetivo de "prestar orientação referente à técnica de planejamento e produção de material audiovisual, à sua utilização efetiva na educação, à elaboração de livros e manuais básicos sobre o ensino por métodos e recursos audiovisuais. Além de promover intercâmbio com estabelecimentos congêneres no país e no exterior, o Serviço Audiovisual do CRPE deverá servir como padrão para outros serviços de ensino audiovisual",

Nove pessoas foram selecionadas para trabalhar como técnicos desse Serviço. Eles realizaram um treinamento de 28 de março a 03 de maio de 1961 com técnicos do Ponto IV $^{6}$. O grupo de especialistas que o Ponto IV enviou ao Brasil era liderados pelo Prof. Homero de Oliveira e pelo Sr. Gastão Norberto Coaracy.

Planejou-se, com a assistência técnica da Divisão de Estudos e Pesquisas Sociais, um levantamento dos recursos audiovisuais em São Paulo. Decidiu-se realizar, primeiramente, o levantamento dos recursos audiovisuais nas escolas normais e escolas primárias do município da Capital.

A DAM realizou, com a colaboração do Ponto IV, a seleção de candidatos a bolsas de estudos para aperfeiçoamento nos EUA em recursos audiovisuais. Inscreveram-se 19 candidatos. Quatro candidatos foram considerados habilitados e foram para os EUA.

Charles Schuller, da Universidade de Michigan, veio a São Paulo para assessorar o planejamento geral e a organização do Serviço de Recursos Audiovisuais.

Em 1961 esse Serviço se desligou da DAM, passando a ser coordenado por Horace C. Hartsell, Porfessor de Educação e Vice Diretor do Departamento Audiovisual da Universidade do Estado de Michigan (EUA). No relatório de atividades desse ano, estão resumidos os trabalhos desenvolvidos: "No decorrer do ano de 1961 foi instalado todo o equipamento pelos funcionários do Serviço, foi estabelecido o procedimento administrativo, foi feito o Organograma e o Quadro dos funcionários com as respectivas funções e foram redigidos os objetivos de trabalho. $\mathrm{O}$ espaço e o equipamento foram aproveitados regularmente e até o máximo das capacidades desde a inauguração do Serviço, a 14 de dezembro de 1960. Grande

\footnotetext{
${ }^{5}$ DIVISÃO DE APERFEIÇOAMENTO DO MAGISTÉRIO, Serviço de Recursos Audiovisuais, Relatório de Atividades do CRPE/SP - 1956-60, Arquivo Histórico do INEP, p.29.

${ }^{6}$ O Ponto IV era um Programa de Cooperação Técnica do Governo dos Estados Unidos criado em 1949 pelo Presidente Harry Truman. Esse Programa, destinado aos países latino-americanos, baseava-se no quarto ponto do discurso de Truman e propunha acordos de cooperação técnica e intercâmbio de serviços técnicos nas áreas de economia, saúde, administração, educação, etc. A formação de professores era o principal objetivo da área educacional do Programa. (Dicionário Histórico Biográfico Brasileiro, p. 2792-3).
} 
número de folhetos e materiais-protótipo foram produzidos e distribuídos a grupos educacionais, desde o ensino primário até o ensino para adultos. Foram programados e realizados numerosos cursos, seminários, demonstrações e estágios durante o ano, assim como um curso de treinamento para os funcionários do Serviço",7.

\section{Seleção de professores e bolsistas.}

A Divisão de Aperfeiçoamento do Magistério foi a responsável pela seleção de professores primários para a nova capital federal. O processo seletivo ocorreu de $1 .^{\circ}$ a 18 de abril de 1959. Dos 107 candidatos inscritos, 17 foram selecionados para trabalhar em Brasília $^{8}$.

Em 1958 e 1959 a DAM também realizou dois processos seletivos para bolsas de estudos oferecidas pelo Ponto IV, para aperfeiçoamento em universidades norte-americanas. Os candidatos deveriam ser professores primários e de educação do magistério estadual.

Em 1958, dos 44 candidatos inscritos, cinco foram selecionados ${ }^{9}$. Em 1959, dos 24 candidatos inscritos, seis foram para os $\mathrm{EUA}^{10}$.

\footnotetext{
${ }^{7}$ SERVIÇO DE RECURSOS AUDIOVISUAIS, Introdução, Relatório de Atividades do CRPE/SP- 1961, Arquivo Histórico do INEP, p. 41.

${ }^{8}$ DIVISÃO DE APERFEIÇOAMENTO DO MAGISTÉRIO, Seleção de professores primários para Brasília, Relatório de Atividades do CRPE/SP - 1959, Arquivo Histórico do INEP, p. 26-7.

${ }^{9}$ BOLSAS de Estudos nos EUA, Pesquisa e Planejamento, n. 2, p. 241.

${ }^{10}$ DIVISÃO DE APERFEIÇOAMENTO DO MAGISTÉRIO, Seleção de professores primários para os EUA, Relatório de Atividades do CRPE/SP - 1956-60, Arquivo Histórico do INEP, p. 29-30.
} 


\section{Capítulo 5 - Serviços Administrativos e Serviços Técnicos Auxiliares.}

No Centro Regional de Pesquisas Educacionais de São Paulo, os Serviços Administrativos estavam a cargo da Secretaria Executiva, que coordenava as seções de Secretaria, Contabilidade, Tesouraria e Almoxarifado.

Os Serviços Técnicos Auxiliares envolviam os trabalhos da Biblioteca e da Seção de Publicações.

O Serviço de Estatística somente foi organizado, como seção autônoma, em 1961. Antes disso, cada Divisão de Pesquisa do Centro realizava as próprias análises estatísticas, auxiliadas por consultores da Faculdade de Filosofia, Ciências e Letras da USP.

Todas as informações apresentadas a seguir foram obtidas através da consulta aos Relatórios Anuais de Atividades do CRPE/SP, de 1956 a 1961.

\section{Secretaria Executiva.}

A Secretaria Executiva era encarregada de executar as ordens expedidas pelo Diretor Geral; supervisionar os serviços administrativos e técnicos auxiliares; e, controlar a portaria, a organização da escala de férias e a administração dos prédios.

A descrição de suas atividades nos Relatórios Anuais de Atividades, permite a observação de características particulares dos prédios e da organização e incremento das atividades do Centro.

Em 1957, o Relatório da Secretaria Executiva acusava a montagem do restaurante e da cozinha que atenderiam aos participantes do I Seminário de Professores Primários. Além disso, a compra de um ônibus é justificada pelas necessidades de transporte de funcionários, distribuição de questionários e coleta de dados no município de São Paulo. A parte do relatório que se destina à descrição dos serviços realizados pelos setores de Manutenção e Limpeza, indica a existência de 41 salas e 22 instalações sanitárias no Centro, que tinha 4.000 $\mathrm{m}^{2}$ de área útil.

A intensificação das atividades do Centro, exigiram a aquisição de outro ônibus em 1959, que deveria atender ao transporte de funcionários, bolsistas, alunos da Escola Experimental, além das atividades de pesquisa. Neste ano, o Centro contava com 77 funcionários.

O número de funcionários do Centro aumentou para 84 em 1960. Neste ano, o Conjunto Residencial do Centro foi inaugurado parcialmente, ele possuía 30 apartamentos 
mobiliados, sendo 15 no $2 .^{\circ}$ andar (seção masculina) e 15 no $6 .^{\circ}$ andar (seção feminina). Cada apartamento poderia alojar duas pessoas e era composto por dormitório, banheiro e varanda de estar.

Em 1. ${ }^{\circ}$ de janeiro de 1961, havia 78 funcionário contratados no Centro. No mês de dezembro do mesmo ano - administração Laerte Ramos de Carvalho - o número de funcionários aumentou para 102.

Em 1961, os Serviços Administrativos estavam a cargo dos seguintes funcionários:

\begin{tabular}{|l|l|}
\hline $\begin{array}{l}\text { Renato Dias dos Santos } \\
\text { Brandão }\end{array}$ & $\begin{array}{l}\text { Secretário Executivo, respondendo pelo controle dos Serviços } \\
\text { Administrativos e Gerais e pela administração dos serviços de } \\
\text { equipamento, manutenção dos prédios, pelos serviços de } \\
\text { Portaria, Transportes e Vigilância. }\end{array}$ \\
\hline Zita Peterffy Kubinszky & $\begin{array}{l}\text { Chefe dos Serviços de Secretaria, respondendo pela Secretaria, } \\
\text { Serviço de Protocolo e arquivo e Serviço do Pessoal. }\end{array}$ \\
\hline Pedro Sebastião Gregório & $\begin{array}{l}\text { Chefe dos Serviços de Contadoria, respondendo pela } \\
\text { contabilidade, Tesouraria, Seção de Compras, Almoxarifado e } \\
\text { Serviço de Patrimônio. }\end{array}$ \\
\hline Emília Candida de Castro & $\begin{array}{l}\text { Chefe do Serviço de Alimentação e Asúde, respondendo pelo } \\
\text { Restaurante e Serviço de Copa e Cozinha. }\end{array}$ \\
\hline
\end{tabular}

\section{Biblioteca.}

a) Aquisições:

\begin{tabular}{|c|c|c|c|c|c|c|c|c|}
\hline & \multicolumn{4}{|l|}{ LIVROS } & \multicolumn{4}{|l|}{ REVISTAS } \\
\hline \multirow[t]{2}{*}{ Ano } & \multicolumn{3}{|l|}{ Compra } & \multirow[t]{2}{*}{ Total } & \multirow[t]{2}{*}{ Assinaturas } & Doação & \multirow[b]{2}{*}{ Diversos } & \multirow[t]{2}{*}{ Total } \\
\hline & & INEP & Diversos & & & INEP & & \\
\hline 1956 & 12 & 2148 & - & 2160 & - & 4 & 5 & 9 \\
\hline 1957 & 32 & 157 & 139 & 328 & 8 & 4 & 14 & 26 \\
\hline 1958 & 581 & 88 & 281 & 950 & 32 & 4 & 62 & 98 \\
\hline 1959 & 109 & 557 & 317 & 983 & 53 & 21 & 128 & 202 \\
\hline 1960 & - & 258 & 236 & 494 & 53 & 29 & 153 & 235 \\
\hline 1961 & $\mathrm{n} / \mathrm{c}$ & $\mathrm{n} / \mathrm{c}$ & $\mathrm{n} / \mathrm{c}$ & 731 & $\mathrm{n} / \mathrm{c}$ & $\mathrm{n} / \mathrm{c}$ & $\mathrm{n} / \mathrm{c}$ & 283 \\
\hline
\end{tabular}

b) Despesas da Biblioteca e volumes emprestados:

\begin{tabular}{|l|l|l|}
\hline ANO & DESPESAS & VOLUMES \\
\hline & Compra de livros e assinaturas de revistas & Empréstimos \\
\hline 1956 & Cr\$ $16.252,00$ & 124 \\
\hline 1957 & Cr\$ $224.633,40$ & 1089 \\
\hline 1958 & Cr\$555.280,40 & 1784 \\
\hline 1959 & Cr\$ $118.450,00$ & 2305 \\
\hline 1960 & Cr\$ $65.661,00$ & 1274 \\
\hline 1961 & n/c & 2864 \\
\hline
\end{tabular}

\section{Seção de Publicações.}

a) Revista Pesquisa e Planejamento: 


\begin{tabular}{|l|l|l|l|}
\hline ANO & $\begin{array}{l}\text { NÚMERO DO } \\
\text { BOLETIM }\end{array}$ & $\begin{array}{l}\text { EXEMPLARES } \\
\text { IMPRESSOS }\end{array}$ & $\begin{array}{l}\text { EXEMPLARES } \\
\text { DISTRIBUÍDOS }\end{array}$ \\
\hline 1957 & 1 & 550 & 515 \\
\hline 1958 & 2 & 1000 & 649 \\
\hline 1959 & 3 & 1000 & 559 \\
\hline 1960 & 4 & 800 & n/c \\
\hline 1961 & s/publicação & s/publicação & s/publicação \\
\hline
\end{tabular}

b) Serviço de Expedição.

Além da publicação do boletim e dos demais trabalhos do Centro, cabia à Seção de Publicações, a partir de 1959, a distribuição das obras destinadas pelo INEP às bibliotecas escolares do São Paulo, Paraná, Mato Grosso e Goiás.

No cadastro da Seção de Publicações constavam, em 1960, 717 estabelecimentos de ensino de grau médio, quase todos públicos, que recebiam obras distribuídas pelo CRPE/SP, expedindo-se maior quantidade de livros para as escolas que acusavam o recebimento com regularidade.

A Seção de Publicações também possuía um cadastro das Faculdades de Filosofia e assemelhadas, tanto públicas como particulares, que recebiam a revista Pesquisa $e$ Planejamento e outras publicações eventuais do Centro.

\begin{tabular}{|l|l|}
\hline Ano & Livros Distribuídos \\
\hline 1959 & 13.616 \\
\hline 1960 & 20.869 \\
\hline 1961 & 27.311 \\
\hline Total & 61.796 \\
\hline
\end{tabular}

\section{Serviço de Estatística.}

O Serviço de Estatística foi inaugurado em 1961, com Lybia de Mattos Bruno como responsável.

Este Serviço, além de realizar as análises estatísticas solicitadas pelas Divisões de Pesquisas do Centro, passou a efetuar trabalhos a serviço de Departamentos da FFCL/USP e a serviço de terceiros.

Em 1961, os seguintes trabalhos foram realizados:

A) A serviço da DEPE e da DEPS:

a. Análise de itens para provas da Escala de Escolaridade para o 1. ${ }^{\circ}$ ano primário. Responsável: Prof. ${ }^{a}$ Maria do Carmo Guedes (DEPE); Consultor Estatístico: Prof. José Furtado Pisani. 
b. Estudos sobre o rendimento na solução de problemas aritméticos na escola primária. Responsáveis: Profs. José Mario Pires Azanha, Frederico de Barros Brotero e Ligia Siniscalco, da DEPE. Consultor estatístico: Álvaro Marchi.

c. Estimativa do crescimento de matrícula para os $4 .^{\circ}$ e $5 .^{\circ}$ anos do curso primário do município de São Paulo, para pesquisa sobre extensão de escolaridade. Responsável: Prof. Nelson Rosamilha, da DEPE. Consultor Estatístico: Prof. Lindo Fava.

d. Levantamento das necessidade de Expansão da Rede Escolar Primária de Presidente Prudente. Responsáveis: Prof. Renato Jardim Moreira (fase inicial) e Prof. Nadir de Almeida Barreto (a partir de 23 de outubro de 1961), do Serviço de Estatística. Consultores Estatísticos: Profs. Álvaro Marchi e Lindo Fava.

e. Estudo sobre a estrutura familiar de Presidente prudente. Responsável: Prof. ${ }^{\text {a }}$ Ruth C. Leite Cardoso. Consultor Estatístico: Prof. Álvaro Marchi.

f. Informações sobre o menor em idade escolar de Presidente Prudente.Responsáveis: Prof. ${ }^{a}$ Ruth C. Leite Cardoso e Armenuhy Kahvegian. Consultor Estatístico: Álvaro Marchi.

g. Política e Expansão da rede Escolar. Responsáveis: Prof. Francisco C. Weffort e, atualmente, o Prof. Celso Beisiegel. Consultor Estatístico: Prof. Lindo Fava.

h. Estudo da distribuição, por idade e série, dos alunos matriculados no curso primário oficial do Estado de São Paulo. Responsabilidade do Serviço de Estatística.

i. Levantamento da bibliografia estatística de interesse do Centro em bibliotecas públicas e universitárias, no município de São Paulo. Responsabilidade do Serviço de Estatística.

B) A serviço de Departamentos da FFCL/USP e terceiros:

a. Escala de atitude. Responsável: Prof. José Mario Pires Azanha.

b. Trabalho de responsabilidade do Departamento de Física Nuclear da FFCL/USP.

c. Trabalho de cálculo para experimento de responsabilidade do Prof. Nelson Rosamilha.

d. Trabalho de responsabilidade do Prof. Fernando Henrique Cardoso. Pesquisa sobre atitude em relação a grupos étnicos, em Porto Alegre.

e. Trabalho de responsabilidade do Prof. Octávio Ianni. Pesquisa sobre atitude em relação a grupos étnicos, em Curitiba.

f. Pesquisa de responsabilidade do Prof. Azis Simão, sobre o comportamento eleitoral do operariado de São Paulo.

g. Pesquisa de responsabilidade do Departamento de Estatística da FFCL/USP, sobre as causas de repetência na escola secundária. 
h. Pesquisa de responsabilidade do Departamento de Estatística da FFCL/USP, sobre o suicídio no Estado de São Paulo.

i. Pesquisa de responsabilidade da Comissão de Energia Nuclear.

j. Pesquisa sobre os tópicos não aprendidos, do programa de $4 .^{\circ}$ ano escolar, pelos alunos sorteados para os ginásios Vocacionais. 


\section{Capítulo 6. Os principais temas discutidos.}

Em setembro de 1959, o Centro Regional de Pesquisas Educacionais de São Paulo promoveu o "Simpósio sobre Problemas Educacionais Brasileiros", no qual educadores e cientistas sociais que trabalhavam no Centro Brasileiro e em todos os Centros Regionais de Pesquisas Educacionais procuraram elaborar um diagnóstico da situação educacional brasileira da época, marcada pelo desenvolvimento urbano e industrial e por mudanças culturais no país.

As comunicações que fizeram parte desse Simpósio foram publicadas em 1967 e 1968, através de dois volumes da Série Estudos e Documentos, editada pelo Centro Regional paulista. O estudo deste material, acrescido dos artigos publicados nas revistas Pesquisa e Planejamento e Educação e Ciências Sociais (de 1956 a 1961), possibilitaram a seleção dos quatro temas que apareceram com maior recorrência nos artigos produzidos pelos intelectuais vinculados ao Centro Regional de Pesquisas Educacionais de São Paulo, durante o período de 1956 a 1961.

Os temas selecionados foram:

1. Educação e Ciências Sociais.

2. Desenvolvimento Sócio-Econômico, Mudança Cultural e Educação.

3. Pesquisa Científica e Planejamento Educacional.

4. Tramitação da Lei de Diretrizes e Bases da Educação Nacional.

A apresentação da forma como esses temas foram discutidos no CRPE/SP procura caracterizar o "ambiente intelectual" que dava sustentação às atividades que se desenvolveram no Centro Regional paulista, tanto em relação às pesquisas e levantamentos propostos, quanto às atividades ligadas ao aperfeiçoamento do magistério.

Para agregar alguns pontos de vista diferentes e atualizados ao estudo dos temas selecionados, foram incluídos - na parte final da apresentação de cada tema - comentários de autores que os pesquisaram e estabeleceram relações com a forma como eles foram tratados no CRPE/SP, no período de 1956 a 1961.

\section{Educação e Ciências Sociais.}

\footnotetext{
${ }^{1}$ Informações sobre o processo de idealização do "Simpósio sobre Problemas Educacionais Brasileiros" e sua realização encontram-se no ANEXO B.
} 
"Atrair para a educação e por a seu serviço as ciências sociais". Essas palavras de Fernando de Azevedo traduzem bem uma das idéias fundamentais que orientaram a idealização e a criação dos Centros de Pesquisas Educacionais, no sentido em que se procurava relacionar os fatos educacionais com os fatos sociais para tornar possível a formulação de uma política educacional para o país.

Desde 1952, com a idealização da Campanha de Inquéritos e Levantamentos do Ensino Médio e Elementar (CILEME) por Anísio Teixeira, já havia a preocupação de entender a escola como sendo uma instituição social e, consequentemente, o seu estudo deveria se estender a certas pesquisas de natureza social que possibilitassem a compreensão da inter-relação entre a escola e seu meio.

No decorrer do processo de criação do CBPE e dos Centros Regionais ocorreram discussões entre educadores e cientistas sociais com o intuito de estabelecer seus planos de trabalho e definir seus objetivos. Um exemplo desse trabalho conjunto foi a reunião de 18 de agosto de 1955, onde as propostas de João Roberto Moreira e Charles Wagley e de Otto Klineberg foram discutidas. Um dos participantes da reunião foi Florestan Fernandes que fez uma exposição crítica a respeito dos documentos discutidos e salientou a necessidade de cooperação entre educadores e cientistas sociais para o estudo dos problemas educacionais brasileiros. Para Florestan Fernandes:

"se quisermos associar educadores e cientistas sociais em trabalhos cooperativos, é essencial que se resolva o problema do ajustamento de ambos no plano da pesquisa e no da produção intelectual voltada para a exploração ou para a transformação da realidade. Nem o educador deve manter a concepção extracientífica de que o cientista social possui o segredo das soluções dos problemas educacionais brasileiros; nem o cientista social deve encarar o educador como um 'técnico' e uma figura secundária nos seus projetos de investigação",3.

$\mathrm{Na}$ definição das diretrizes de trabalho que os Centros deveriam adotar para atingir seus objetivos é clara a ênfase nas relações entre as pesquisas em ciências sociais e as pesquisas educacionais com a finalidade de contribuírem para elaborar os fundamentos de uma política educacional. Exemplos dessa ênfase podem ser tomados em dois de seus tópicos:

“f) A pesquisa em ciências sociais deve ser explorada amplamente, para que seja possível obter conhecimentos positivos sobre as condições de existência na sociedade brasileira e sobre o modo de integração e de funcionamento do sistema escolar dentro dela;

\footnotetext{
2 [Fernando de AZEVEDO], Apresentação, Pesquisa e Planejamento, n. 1, p. 02.

${ }^{3}$ Florestan FERNANDES, Educação e Sociedade no Brasil, p. 567.
} 
g) A pesquisa educacional dever ser explorada de maneira que permita o aproveitamento regular dos resultados da pesquisa em ciências sociais, sempre tendo em vista as possibilidades de ajustar o sistema educacional às condições de existência e às exigências de desenvolvimento econômico, social e cultural das diversas regiões do país" 4 .

Além disso, a própria atribuição de funções à Divisão de Estudos e Pesquisas Sociais do CBPE e dos Centros Regionais destaca a necessidade de se realizarem pesquisas que permitam a compreensão mais profunda "dos fatos educacionais em suas relações com a vida social" $"$.

Anísio Teixeira, no encerramento do I Seminário de Professores Primários, realizado no CRPE/SP, em fevereiro de 1957, fez uma conferência - que seria publicada sob o título "Ciência e Arte de Educar"6 - na qual tratou da questão da necessidade de um trabalho conjunto de cientistas sociais e educadores para que a pesquisa educacional se desenvolvesse no país e colaborasse para a "reconstrução educacional" brasileira:

"A originalidade dos Centros está em sublinhar especialmente essa nova relação entre o cientista social e o educador. Até ontem, o educador julgava dispor de uma ciência autônoma, por meio da qual iria criar simultaneamente um conhecimento educacional e uma arte educacional. E o cientista social estudava outros problemas $e$ nada tinha diretamente a ver com a educação. Quando resolvia cooperar com o educador, despia-se de sua qualidade de cientista e se fazia também educador. Os Centros vêm tentar associá-los em uma obra conjunta, porém com uma perfeita distinção de campos de ação. O sociólogo, o antropólogo e o psicólogo social não são sociólogos educacionais, ou antropólogos educacionais ou psicólogos educacionais, mas eles mesmos estudando problemas de sua especialidade, embora originários das 'práticas educacionais'. (...)Acreditamos que esse encontro entre cientistas sociais e educadores 'científicos' será da maior fertilidade e, sobretudo, que evitará os equívocos ainda tão recentes da aplicação precipitada de certos resultados de pesquisas científicas nas escolas, sem levar em conta o caráter próprio da obra educativa. (...)Cientistas e educadores trabalharão juntos, mas uns e outros, respeitando o campo de ação de cada um, mutuamente se auxiliando na obra comum de descobrir o conhecimento e suas possibilidades de aplicação" 7 .

A reedição de "A estrutura da escola", , de Antônio Cândido, na revista Educação e Ciências Sociais de agosto de 1956, foi primeiro trabalho produzido por um intelectual

\footnotetext{
${ }^{4}$ OS ESTUDOS e as pesquisas educacionais no Ministério da Educação e Cultura, Educação e Ciências Sociais, n. 1, p. $51-2$.

5 Ibidem, p. 54.

${ }^{6}$ Este trabalho foi publicado pela revista Pesquisa e Planejamento, n. 1, de junho de 1957; pela revista Educação e Ciências Sociais, n. 5, de agosto de 1957; pela Revista Brasileira de Estudos Pedagógicos, v. 28, n. 68, de dezembro de 1957; e, pelo livro Educação e o Mundo Moderno, de 1977.

${ }^{7}$ Anísio TEIXEIRA, Ciência e Arte de Educar, Pesquisa e Planejamento, n. 1, p. 79-82.

${ }^{8}$ Este trabalho havia sido publicado pela Faculdade de Filosofia da USP, em 1953.
} 
vinculado ao Centro Regional paulista, a respeito das relações entre Ciências Sociais e Educação, que foi publicado em uma das fontes consultadas para a realização desta pesquisa.

Antônio Cândido apresentou esse trabalho da seguinte forma: "Trata-se inicialmente de saber qual a contribuição que a Sociologia pode dar ao educador" ${ }^{\text {"9 }}$. Nele, a escola é tratada como sendo um grupo social, o que lhe confere uma dinâmica própria, característica da estrutura total da escola (muito mais ampla que sua estrutura meramente administrativa). Segundo o autor, somente a análise sociológica do grupo social escolar forneceria ao educador a capacidade de apreensão da realidade total da escola que deixaria de lhe parecer como apenas um "estabelecimento de ensino a ser enquadrado nas normas racionais da Legislação Escolar" assim dizer único: que requer ajustamento correspondente destas normas, visto como possui outras [que são fruto da integração de seus membros], que devem ser levadas em conta. (...)A adoção deste ponto de vista alarga e aprofunda a visão do educador, permitindo-lhe uma ação educacional também mais larga e compreensiva" ${ }^{11}$.

O Diretor do Centro Regional paulista, Fernando de Azevedo, tratou da relação entre Educação e Ciências Sociais em várias ocasiões. No discurso de inauguração do CRPE/SP, ele afirmou que as pesquisas sociais serviriam "para esclarecer situações, iluminar caminhos e, lançando-lhes bases mais sólidas, traçar diretrizes seguras à reconstrução educacional" ${ }^{, 12}$. No mesmo discurso, Fernando de Azevedo acrescentou:

"Entre as idéias segundo as quais se orientou o planejamento geral dos Centros, uma das de maior alcance científico e prático, de uma parte, e por outra, das mais caras a sociólogos e antropólogos é a íntima colaboração das ciências sociais e das ciências educacionais. Sempre me pareceu da mais alta importância para a educação, aproximar dela e fazer para ela convergirem as ciências sociais, destinadas a examinar os seus problemas de um novo ângulo e a fecundar esse campo, em que as idéias e doutrinas, a organização das escolas e dos sistemas educacionais, as técnicas pedagógicas e o próprio tipo de relação entre mestres e discípulos não se podem compreender e explicar senão em face e à luz das estruturas econômicas, sociais e políticas" $" 13$.

Em outro discurso, na abertura do I Seminário de Professores Primários, Fernando de Azevedo declarou:

\footnotetext{
${ }^{9}$ Antônio CÂNDIDO, A estrutura da escola, Educação e Ciências Sociais, n. ${ }^{\text {2 }}$ 2, p. 139.

${ }^{10}$ Ibidem, p. 140.

${ }^{11}$ Ibidem, p. 140.

${ }^{12}$ Fernando de AZEVEDO, Inauguração do CRPE, Pesquisa e Planejamento, n. 1, p. 06.

${ }^{13}$ Ibidem, p. 10.
} 
"O Centro que vos acolhe é, pois, antes de tudo, na concepção dos que o instituíram e organizam, um vasto laboratório de pesquisas e experiências, no domínio das ciências humanas e sociais, utilizadas em benefício do ensino de todos os tipos e graus. Esse, o seu maior alcance e seu sentido revolucionário que consiste exatamente em atrair e por as ciências sociais a serviço da educação e procurar, nas pesquisas científicas, as respostas às nossas perguntas" $" 14$.

Wilson Martins, um dos conferencistas participantes do I Seminário de Professores Primários, também tratou das relações entre Educação e Ciências Sociais afirmando que "a mais importante contribuição que as ciências sociais podem trazer para a educação é a que consiste em fornecer aos mestres e aos discípulos o conhecimento da realidade social em que vivem" 15 . Nesse sentido, Wilson Martins também afirmou: "de tudo o que a Educação pode esperar das Ciências Sociais, os benefícios mais fecundos serão representados pela abertura dos horizontes mentais dos professores. Para que a escola seja social, é preciso que o professor pense e sinta socialmente" $" 16$.

Renato Jardim Moreira, Diretor da Divisão de Estudos e Pesquisas Educacionais do CRPE/SP, escreveu artigos que contribuíram não apenas para a definição de idéias orientadoras para as pesquisas que se realizavam, como também preocupou-se com a metodologia a ser empregada nessas pesquisas. A respeito da pesquisa social no campo da educação escreveu: "Como a atividade científica se legitima pela sua possível contribuição à melhoria das condições de vida do homem, a pesquisa social no campo da educação deve fornecer elementos para o planejamento e a implantação de uma política educacional"17.

Florestan Fernandes, discutindo as transformações sociais ocorridas na cidade de São Paulo, também trata da questão das relações entre Ciências Sociais e Educação. Para ele, as Ciências Sociais forneceriam ao homem recursos intelectuais novos que o tornariam capaz de perceber como as forças do mundo urbano e metropolitano se manifestam. Assim, os recursos escassos dos países subdesenvolvidos poderiam ser melhor utilizados na luta contra os graves problemas sociais:

"Se conseguirmos, simultaneamente: a) proporcionar meios suficientes para a expansão do ensino e da pesquisa no campo das ciências sociais; $b$ ) desenvolver nos cientistas sociais uma mentalidade realista, suscetivel de favorecer novas combinações de alvos empíricos, técnicos e práticos na pesquisa científica; $c$ ) despertar nos leigos maior interesse pela espécie de colaboração que poderiam

\footnotetext{
${ }^{14}$ Fernando de AZEVEDO, Luz nova sobre os caminhos, Pesquisa e Planejamento, n. 1, p. 16.

${ }^{15}$ Wilson MARTINS, O novo Emílio - o que a educação pode esperar das ciências sociais, Pesquisa $e$

Planejamento, n. 1, p. 38.

${ }^{16}$ Ibidem, p. 50.

${ }^{17}$ Renato Jardim MOREIRA, Pesquisa e Política Educacional, Pesquisa e Planejamento, n. 3, p. 35.
} 
receber dos cientistas sociais - estaremos em condições de enfrentar melhor os problemas humanos que decorrem do crescimento rápido e da transformação desordenada de uma cidade como São Paulo"18.

Também é de Florestan Fernandes a principal contribuição do Simpósio sobre Problemas Educacionais Brasileiros à discussão desse tema. No trabalho apresentado, Florestan Fernandes propõe a associação de "cientistas sociais e educadores em projetos que contribuam, definitivamente para a descoberta de meios adequados, econômicos e rápidos de intervenção racional na estrutura e no funcionamento do sistema educacional brasileiro"19.

No seu entender, a maior tarefa com que se defrontavam os educadores e os cientistas sociais da época era a de "adaptar a educação aos recursos fornecidos pela ciência e às exigências da civilização científica" ${ }^{20}$. A sugestão de Florestan Fernandes para a execução dessa tarefa seria a criação de uma disciplina de síntese na qual "a pesquisa fundamental e a teoria fossem exploradas, sistematicamente, na análise dos problemas educacionais e dos modos de resolvê-los"21.

Entretanto, o autor acredita que surgiriam dificuldades a serem enfrentadas, tanto por educadores, quanto por cientistas sociais:

"A preparação científica dos educadores ressente-se de seu caráter predominantemente informativo e livresco. Em regra, falta-lhes o domínio autêntico do ponto de vista científico. (...) A experiência dos cientistas sociais, na área da educação, nasce dos centros de interesses impostos por eventuais investigações sobre as condições e os efeitos psico-sociais ou sócio-culturais de atividades educacionais. Ao contrário do educador, sua capacidade de situar os problemas educacionais em ângulos práticos é muito pobre" ${ }^{\text {22 }}$.

A disciplina de síntese teria que se basear na cooperação interdisciplinar e corresponder a questões de ordem prática. Nesse sentido, o educador colaboraria propondo fins ideais que somente poderiam ser definidos através do raciocínio pragmático puro. Por outro lado, o cientista social efetuaria a "análise dos efeitos presumíveis da intervenção racional, tendo em vista a eficácia dos meios de controle disponíveis, as tendências de reintegração inerentes às condições reais de organização e de funcionamento do sistema

\footnotetext{
${ }^{18}$ Florestan FERNANDES, O homem e a cidade-metrópole, Educação e Ciências Sociais, n. 11, p. 43.

${ }^{19}$ Florestan FERNANDES, A ciência aplicada e a educação como fatores de mudança social provocada, Estudos

e Documentos, vol. 5, p. 45.

${ }^{20}$ Ibidem, p. 18.

${ }^{21}$ Ibidem, p. 19.

${ }^{22}$ Ibidem, p. 19.
} 
educacional considerado e o grau de congruência dos fins ideais propostos com as referidas tendências dinâmicas" ${ }^{23}$.

Para Florestan Fernandes, os trabalhos desenvolvidos nos Centros de Pesquisas Educacionais proporcionariam novas possibilidades de conhecimento sistemático e de tratamento objetivo dos problemas educacionais brasileiros:

"Graças às oportunidades de trabalho cooperativo, criadas por uma instituição como o CBPE, os papéis intelectuais de ambos [cientistas sociais e educadores] são inseridos, diretamente, na esfera em que a atividade humana se volta, inteligente $e$ racionalmente, para a alteração do estado de subdesenvolvimento do país e a correção de suas consequências que afetem as possibilidades de progresso"24.

Entretanto, na parte final de sua comunicação, o autor pondera:

"Convém não exagerar os efeitos inovadores, socialmente construtivos, dessa colaboração. Ela é insuficiente, por si mesma, para libertar a educação sistemática das teias invisíveis que restringem ou deterioram as funções das escolas brasileiras, como fatores de progresso social. Com isso, queremos dizer que se impõe associar as reformas e os planos educacionais a outras modalidades de intervenção na realidade. A compartimentalização, imperante nos serviços públicos brasileiros, revela-se notoriamente no funcionamento das instituições educacionais e na mentalidade com que os educadores procuram enfrentar os problemas educacionais brasileiros. Ela precisa ser combatida, para ceder lugar a um estilo de ação que nos leve a considerar a solução dos problemas educacionais à luz dos vários fatores que concorrem em sua produção e, por isso, precisam se manipulados simultaneamente. A contribuição dos cientistas sociais poderá ser deveras construtiva para a constituição de tal estilo de ação e da mentalidade correspondente, favorável à conjugação dos serviços públicos, onde isso for recomendável. Não obstante, mesmo que essa condição se realize, convém não esquecer que a eficácia das medidas educacionais - inclusive das que parecerem bem sucedidas - será ilusória, enquanto elas não encontrarem condições de vida social organizada suscetíveis de preservar ou de renovar a espécie de 'melhoria' que acarretarem,"25.

\subsection{Comentários sobre o tema: A "sociologização" do pensamento pedagógico brasileiro.}

Luiz Pereira $^{26}$ foi pesquisador da Divisão de Estudos e Pesquisas Sociais do CRPE/SP de 1957 a 1959. Em 1960, ele apresentou a monografia "A escola numa área metropolitana" como trabalho de conclusão dos estudos de especialização em Sociologia e, em 1961,

\footnotetext{
${ }^{23}$ Ibidem, p. 20.

${ }^{24}$ Ibidem, p. 68.

${ }^{25}$ Ibidem, p. 73-4.

${ }^{26}$ Os dados biográficos a respeito de Luiz Pereira, apresentados a seguir, foram fornecidos pelo trabalho de Celso de Rui Beisiegel no Dicionário de educadores no Brasil, p. 356-9.
} 
defendeu sua tese de doutorado com o trabalho intitulado "O magistério primário numa sociedade de classes". Nos dois trabalhos, seu orientador foi Florestan Fernandes.

Em 1962, no II Congresso Brasileiro de Sociologia, Luiz Pereira apresentou o trabalho "Nota crítica sobre o pensamento pedagógico brasileiro" 27 , no qual propõe-se a analisar alguns componentes típicos da reflexão pedagógica produzida por educadores e cientistas sociais no Brasil. Nesse trabalho, o autor faz várias considerações sobre as relações entre cientistas sociais e educadores que são muito importantes para a compreensão de como esse tema era tratado no CRPE/SP.

Para Luiz Pereira, educadores e cientistas sociais desenvolvem dois "estilos de pensamento" pedagógico não integrados: enquanto os educadores entendem as instituições escolares como um dos centros dinâmicos do sistema social global, os cientistas sociais evidenciam as dimensões socializadoras das instituições e dos processos não-escolares e, além disso, procuram evidenciar os condicionantes extra-escolares da estrutura e do funcionamento das instituições escolares. Para o autor, vivia-se um momento de "sociologização" do pensamento pedagógico brasileiro, isto é, o fortalecimento do "estilo de pensamento" pedagógico dos cientistas sociais e a decadência do "estilo de pensamento" pedagógico dos educadores.

Conforme Luiz Pereira, para haver a reintegração do sistema de papéis sociais dos educadores e cientistas sociais seria necessária a redefinição das tarefas intelectuais de cada um deles: haveria uma retração temática por parte dos "novos" educadores, que passariam a estudar somente as possibilidades de ajustamento das instituições escolares às necessidades sociais (formulando planos de reforma escolar e propondo medidas para racionalizar a organização escolar); e, por outro lado, haveria uma ampliação temática do pensamento dos "novos" cientistas sociais, que se ocupariam do estudo dos múltiplos aspectos das relações dinâmicas entre escola e sociedade. Somente através dessa reintegração que, segundo Luiz Pereira, o problema fundamental do pensamento pedagógico seria enfrentado: a identificação do grau de potencialidade dinâmica da educação escolar confrontada com outros setores do sistema social global.

Vários autores se dedicaram à explicação desse processo de "sociologização" apontado por Luiz Pereira.

\footnotetext{
${ }^{27}$ Publicado na Revista Brasiliense, n. ${ }^{\circ}$ 43, set./out. 1962 e como apêndice à segunda edição do livro A escola primária numa área metropolitana, 1967.
} 
Para Aparecida Joly Gouveia, a partir de 1956 - com a criação do CBPE e dos Centros Regionais - até 1964, houve um deslocamento da ênfase predominantemente psicopedagógica para estudos de natureza sociológica a respeito dos problemas educacionais. "Nesse período produziram-se, sob a responsabilidade de sociólogos e antropólogos, monografias, surveys e tentativas de análise macroscópica em que o foco de atenção são as relações entre a escola, ou o sistema escolar, e certos aspectos da sociedade local, regional ou nacional"28.

Mariza Corrêa acredita que os projetos desenvolvidos no CBPE, na década de 50, representaram a transição entre um primeiro momento da história das Ciências Sociais - o momento das grandes sínteses - e um terceiro momento que se inaugura com a reforma do ensino universitário no final da década de 60 e surgimento da pós-graduação ${ }^{29}$. Para a autora, na década de 50 procurava-se verificar a "realidade brasileira" através da pesquisa empírica, "estimulada tanto por um interesse vindo do exterior quanto por uma ânsia de autoconhecimento razoavelmente bem estabelecida como tradição entre a intelectualidade brasileira" 30 .

Carlos Benedito Martins é um autor que acredita que "o tema educação teve, na década de 50, portanto num momento decisivo do processo de institucionalização das ciências sociais brasileiras, um papel essencial e de grande visibilidade, em termos de pesquisas. (...) Durante esse período e na década seguinte, a educação igualou-se a outros temas, então privilegiados, tais como o da urbanização, da industrialização, do desenvolvimento econômico. Sociólogos e antropólogos, financiados em grande parte pelo INEP e pelos CRPEs, realizaram várias pesquisas sobre escolas, alunos e professores"31.

Luiz Antônio Cunha acredita que Anísio Teixeira, através do CBPE e dos Centros Regionais, "criou condições para uma importante produção sociológica sobre a educação, nos anos 50 e começo dos 60,32. Referindo-se aos Centros e à revista Educação e Ciências Sociais o autor afirma que eles "delimitavam um campo de produção da sociologia da educação, ainda que incipiente e desigual" ${ }^{\text {33. }}$.

Marcos Cezar de Freitas afirma que, nos anos 50, os intelectuais discutiam a configuração de um campo próprio para a pesquisa educacional. Esses intelectuais "por um lado retomavam estudos locais com os quais recuperavam dimensões singulares da cultura

\footnotetext{
${ }^{28}$ Aparecida Joly GOUVEIA, A pesquisa educacional no Brasil, Cadernos de Pesquisa, n. 1, p. 02-4.

${ }^{29}$ Mariza CORRÊA, História da antropologia no Brasil: 1930-1960, p. 21-2.

${ }^{30}$ Ibidem, p. 22.

${ }^{31}$ Carlos Benedito MARTINS, Educação e Sociologia: uma relação possível?, Cadernos CEDES, n. 27 , p. 07.

${ }^{32}$ Luiz Antônio CUNHA, A educação na sociologia: um objeto rejeitado?, Cadernos CEDES, n. 27, p. 09.
} 
brasileira e, com isso, conformavam um novo perfil para as ciências sociais às quais deveriam atuar como 'ciências fonte' do debate educacional; por outro lado, empenhavam-se na articulação de projetos com os quais muitas vezes passavam a atuar como 'inteligência' no interior do Estado" ${ }^{34}$. Este autor também acredita que a UNESCO teve um papel fundamental na reformulação das ciências sociais e da pesquisa educacional no Brasil. Através da UNESCO houve, a partir de 1952, uma aproximação entre Anísio Teixeira e especialistas estrangeiros (Charles Wagley, Jacques Lambert, Otto Klineberg, Andrew Pearse e Bertram Hutchinson). Essa colaboração seria decisiva para a aproximação intensa que ocorreu entre sociólogos, antropólogos e educadores ${ }^{35}$.

Marcus Vinicius da Cunha, em sua tese de doutorado, discute os trabalhos desenvolvidos pelo CBPE e pelo Centro Regional paulista, através da análise dos artigos publicados nas revistas Pesquisa e Planejamento e Educação e Ciências Sociais. Para o autor, existe uma predominância das ciências sociais nas análises da problemática educacional realizada no $\mathrm{CBPE}^{36}$. No CRPE/SP, a associação entre cientistas sociais e educadores também é vista como de "grande utilidade para que se possa buscar a solução dos problemas educacionais",37.

Libânia Nacif Xavier também trata da relação entre Ciências Sociais e Educação no CBPE em pelo menos dois trabalhos. Para a autora o CBPE "desempenhou um importante papel no processo de construção de uma tradição de estudos no campo da educação"38. Essa nova tradição de pesquisa "deveria estar iluminada por uma abordagem sócio-antropológica. As ciências sociais teriam na interação com a escola, com os agentes educacionais e os sistemas de ensino um vasto campo para o desenvolvimento de investigações científicas e para sua legitimação como instrumento de ajustamento social" ${ }^{\prime 39}$.

Em outro trabalho, Libânia Nacif Xavier também destaca a importância dessa articulação entre Educação e Ciências Sociais para a o projeto de fundação do CBPE que “correspondeu a uma dupla perspectiva: ao mesmo tempo em que incentivava o

\footnotetext{
${ }^{33}$ Ibidem, p. 10.

${ }^{34}$ Marcos Cezar de FREITAS, Memória intelectual da educação brasileira, p. 66.

${ }^{35}$ Marcos Cezar de FREITAS, Da idéia de regional no projeto do Centro Regional de Pesquisas Educacionais de São Paulo, p. 25.

${ }^{36}$ Marcus Vinicius da CUNHA, Indivíduo e Sociedade no ideário escolanovista (Brasil: 1930-1960), p. 149-65.

${ }^{37}$ Ibidem, p. 183-92.

${ }^{38}$ Libânia Nacif XAVIER, Por que não lemos Anísio Teixeira? Uma tradição esquecida, p. 85-139.

${ }^{39}$ Ibidem, p. 91.
} 
desenvolvimento das ciências sociais, visava atrair o interesse dos cientistas sociais para o estudo dos problemas educacionais" ${ }^{\text {" }}$.

\section{Desenvolvimento Sócio-econômico, Mudança Cultural e Educação.}

Para caracterizar o "ambiente cultural" dos anos 50, Leandro Konder afirma que "a fisionomia do começo da década era uma e a do final já era outra, bastante diferente. (...) Não podemos deixar de nos impressionar com as transformações aceleradas e imprevistas que se desencadearam naquele momento" ${ }^{\prime 1}$. Nesse contexto de grandes transformações políticas, sociais e econômicas no Brasil, o tema do desenvolvimento e da mudança cultural e suas relações com a educação foi bastante discutido pelos intelectuais que participavam das atividades do CRPE/SP.

No discurso de abertura do I Curso de Especialistas em Educação para a América Latina, realizado em 1958, Malcolm Adiseshiah, subdiretor geral da UNESCO, trata diretamente da questão do desenvolvimento econômico e suas relações com a educação ao apontar a erradicação do analfabetismo como uma necessidade prática, econômica e social dos países subdesenvolvidos: “O caminho para aumentar a riqueza material de seus países é conseguir que todas as pessoas possam ir à escola e, além disso, melhorar essas escolas de tal forma que seus alunos se desenvolvam numa força industrial e agrícola inteligente, alfabetizada e adaptável" ${ }^{, 42}$.

No "Manifesto dos Educadores", publicado pela revista Pesquisa e Planejamento de 1959, as preocupações com o desenvolvimento econômico e a política educacional brasileira também estavam presentes:

"O rápido crescimento demográfico, nestes últimos trinta anos; o processo de industrialização e urbanização que se desenvolve num ritmo e com intensidade variáveis de uma para outra região; as mudanças econômicas e sócio-culturais que se produziram, em consequência, são alguns dos fatores que determinaram esse desequilíbrio e desajustamento entre o sistema de educação e as modificações surgidas na estrutura demográfica e industrial do país. Processou-se o crescimento espontâneo da educação, pela própria força das cousas, e tanto mais desordenadamente quanto, em vez de se ampliar, se reduziu a ação coordenadora do poder público, federal e estadual, que não se dispuseram também a dominar e a canalizar as forças sociais e políticas libertadas pelas mudanças que se operaram na estrutura econômica e industrial",43.

\footnotetext{
${ }^{40}$ Libânia Nacif XAVIER, O Brasil como laboratório: educação e ciências sociais no projeto dos Centro Brasileiro de Pesquisas Educacionais, p. 103.

${ }^{41}$ Leandro KONDER, Historiografia brasileira em perspectiva, p. 355.

${ }^{42}$ Malcolm S. ADISESHIAH, A UNESCO e a luta contra o analfabetismo, Pesquisa e Planejamento, n. 2, p. 67.

${ }^{43}$ MANIFESTO dos Educadores, Pesquisa e Planejamento, n. 3, p. 78.
} 
Para os signatários do Manifesto, o sistema educacional teria que passar a atender às novas demandas da sociedade industrial:

“As profundas transformações operadas em consequência da preponderância da economia industrial sobre as formas econômicas que a precederam, determinam, de fato, e têm de determinar, nos sistemas de ensino, grandes mudanças que permitam ampla participação de todos em estudos e práticas, desde a escola primária completa até os mais altos níveis de estudos superiores. "44.

No Simpósio sobre Problemas Educacionais Brasileiros, de 1959, este foi um dos principais temas discutidos. Fernando Henrique Cardoso e Octávio Ianni apresentaram um trabalho que fornece uma visão geral do raciocínio que seria seguido pelos intelectuais vinculados ao CRPE/SP a respeito dessas questões.

Os autores informam que, até 1940, o processo de industrialização no Brasil caracterizou-se por um crescimento descontínuo, com "surtos de industrialização" esparsos. Depois da Segunda Guerra Mundial, o processo de industrialização acentuou-se e surgiram condições capazes de estimular o desenvolvimento industrial de forma contínua e crescente. Essas transformações provocaram desajustamentos em algumas esferas da cultura, criando situações que podiam ser definidas como problemas sociais: "No Brasil, um dos mais sérios problemas resultantes do crescimento industrial rápido, e que está exigindo medidas racionais e práticas para a sua solução, é o da inadequação do sistema educacional à nova ordem econômica e social emergente" 45 .

Na opinião desses autores, o grande problema que se colocava ao educador não era elaborar um sistema de ensino que servisse à industrialização isoladamente, mas "projetar um tipo de educação que sirva à industrialização enquanto processo integrado noutro mais geral: o de transformação de toda uma estrutura sócio-econômica» ${ }^{\natural 4}$. Isso ocorria porque, entre nós, o processo de crescimento industrial significava a transformação de uma economia de base agrária numa economia nacional de base capitalista:

“Ao mesmo tempo, pois, esse processo dependerá e resultará na transformação da antiga sociedade patriarcal, estratificada em camadas rígidas, na sociedade democrática de classes abertas. É em função desta transformação mais geral, e tendo consciência da importância do crescimento industrial para que ela se efetue, que o educador precisa pensar nas reformas educacionais" $"$.

\footnotetext{
${ }^{44}$ Ibidem, p. 100.

${ }^{45}$ Fernando Henrique CARDOSO e Octávio IANNI, As exigências do processo de industrialização, Estudos e Documentos, vol. 6, p. 198.

${ }^{46}$ Ibidem, p. 201.

${ }^{47}$ Ibidem, p. 202.
} 
A complexidade dessa tarefa era ainda mais intensa em função da necessidade, apontada pelos autores, de democratização do sistema educacional. Para eles, a seletividade do nosso sistema educacional representava um fator de demora cultural, que retardava o desenvolvimento econômico e social.

A democratização da educação citada pelos autores consiste, em primeiro lugar, na educação primária pública, universal, gratuita e obrigatória. Em segundo lugar, consiste na homogeneização dos valores compartilhados pelos educandos, com ênfase na igualdade fundamental do trabalho como realização humana, seja ele manual, intelectual ou artístico. Em terceiro lugar, a reforma de ensino deveria estender-se ao ensino médio e superior, uma vez que a expansão industrial e a urbanização exigiam uma gama variada de mão de obra treinada (operários, mestres, técnicos e pessoal de nível superior) que não estava sendo preparada pelo sistema de ensino da época.

Fernando Henrique Cardoso e Octávio Ianni também discutem a ação do educador numa sociedade em mudança que tende para a industrialização de seu processo produtivo. $\mathrm{O}$ educador deveria ter em mente dois pontos principais:

1. A escola faz parte do sistema social inclusivo:

"Se é verdade que podemos manipular a educação como uma técnica social de interferência na realidade, não é menos verdade que ela faz parte desta mesma realidade e, por isso, está submetida aos processos gerais que regulam o funcionamento da sociedade, seja aqueles que atuam como fatores de preservação da ordem social, seja os que provocam transformações. (...) Os resultados e os limites da capacidade de modificação da realidade dos sistemas educacionais são regulados pela sociedade inclusiva. O educador para não ser um utopista, saberá, partindo de valores criados pela própria sociedade, escolher meios que, manipulados racionalmente, permitam atingir fins socialmente possíveis e desejados ${ }^{, 48}$.

2. O educador pode interferir racionalmente na realidade:

"É possível organizar o sistema educacional de tal forma que sejam utilizados os meios mais adequados para a obtenção daquelas metas (educação democrática e técnica), a partir de uma estratégia que, considerando o atraso econômico e cultural existente, procure diminuí-lo, sem contudo propor-se fins que estejam muito além das necessidades e das condições reais da existência da sociedade. Dessa forma o sistema educacional poderá também ser organizado de tal maneira que se torne, ao mesmo tempo, um fator de transformação e de regulamentação social impedindo que irrompam os efeitos menos desejáveis que a mudança rápida pode acarretar nos sistemas sociais" ${ }^{, 49}$.

\footnotetext{
${ }^{48}$ Ibidem, p. 206-7.

${ }^{49}$ Ibidem, p. 208.
} 
As considerações apresentadas por Fernando Henrique Cardoso e Octávio Ianni demonstram que o sistema educacional da época não satisfazia às necessidades do desenvolvimento econômico. Esse problema criava duas consequências indesejáveis:

"Por um lado, dificulta a introdução de técnicas realmente capitalistas de produção, pois que estas dependem da invenção tecnológica e da utilização de material humano devidamente treinado. Por outro lado, torna-se uma fonte de determinados tipos de tensão social que emergem na sociedade como consequência da preservação de ideais tradicionais da formação da juventude que já não correspondem às condições vigentes de existência social" ${ }^{\text {50 }}$.

Para os autores, o educador deveria desempenhar o seguinte papel:

"Colaborar na realização da evolução científica, essencial ao pleno desenvolvimento do processo de industrialização. O problema crucial que se coloca ao sistema de ensino, pois, é possibilitar a aplicação dos conhecimentos científicos disponíveis, transformados em recursos técnicos. A ciência como um todo, e em cada uma das suas partes, é um instrumento de que o homem pode lançar mão, não apenas para ajustarse às condições emergentes numa dada situação, mas também para atuar sobre aquelas condições, provocando desenvolvimentos que poderão beneficiar a coletividade mais rapidamente"

Em outra comunicação que fez parte do Simpósio, Florestan Fernandes fez importantes considerações sobre as possibilidades de utilização da educação como um fator racional de mudança social.

$\mathrm{O}$ autor destaca a necessidade de se compreender o entrosamento dos recursos e alvos educacionais com a evolução do sistema social. Para Florestan Fernandes, a educação, sozinha, não dá ao homem a capacidade de modificar a realidade social:

“As vias racionais só são dinamicamente construtivas quando o processo educacional corresponde a necessidades percebidas no plano da consciência social. Em conjunto, os dois pontos alimentam a convicção de que a manipulação racional das condições externas do processo educacional apresenta interesse prático específico" ${ }^{2}$.

De acordo com Florestan Fernandes, a educação seria um fator de mudança cultural provocada:

"O que caracteriza a mudança cultural provocada, em relação ao elemento racional, é a extensão dos limites da ação intencional. Além da escolha deliberada dos alvos, ela envolve o conhecimento objetivo dos meios, das condições e dos mecanismos através dos quais aqueles precisam ser atingidos. Em outras palavras, o elemento racional penetra em todos os níveis do comportamento inteligente dos agentes, de modo a ordenar as atividades por eles desenvolvidas no plano relativamente abstrato,

\footnotetext{
${ }^{50}$ Ibidem, p. 229.

${ }^{51}$ Ibidem, p. 229.

${ }^{52}$ Florestan FERNANDES, A ciência aplicada e a educação como fatores de mudança social provocada, Estudos e Documentos, vol. 5, p. 37.
} 
em que se definem suas intenções de intervir na realidade, seja em função dos fins, seja em função dos meios e das condições da própria intervenção. (...) Verifica-se que a importância crescente do elemento racional é consequência de um processo social, pelo qual os recursos culturais do homem são reajustados às exigências da vida em sociedade na era da civilização tecnológica e industrial",53.

O autor esclarece que os sociólogos ou os educadores não podem "resolver" os problemas educacionais brasileiros:

“Os problemas educacionais brasileiros só poderão ser resolvidos através de mudança social organizada. Isso que dizer que o destino prático das contribuições dos sociólogos depende, diretamente, da maneira pela qual eles forem incluídos nesse processo social. Doutro lado, também indica que o sucesso final de qualquer projeto de intervenção na realidade, por mais 'científica' e 'positiva' que seja sua orientação, constitui uma função da possibilidades de mudança do meio social ambiente. Os especialista precisam dispor, além dos conhecimentos sobre a situação e os alvos a serem atingidos, de condições de trabalho socialmente ordenadas, suscetíveis de regular, institucionalmente, sua participação na elaboração e na aplicação de planos de controle racional" ${ }^{54}$.

Concluindo, o autor destaca a importância dos Centros de Pesquisas Educacionais, uma vez que eles proporcionam uma base institucional para a aplicação de planos de controle educacional.

Luiz Pereira, em sua participação no Simpósio de 1959, critica os educadores que supervalorizam o poder da escola como agência de mudança nas sociedades economicamente desenvolvidas, relegando a um plano secundário os fatores extra-escolares responsáveis por problemas educacionais e por problemas em setores básicos da vida nacional.

Os fatores extra-escolares podem ser definidos como as características da comunidade na qual a escola está inserida. Para Luiz Pereira, os educadores deveriam mudar sua atitude para com essas variáveis e para com os problemas nacionais não especificamente educacionais:

"Trata-se por assim dizer, de assumir responsabilidades e posições extrapedagógicas, do que representa um exemplo o recente Manifesto dos Educadores: um documento mais político do que estritamente pedagógico. Trata-se em suma, de assumir uma atitude não romanticista, não moralista nem jurídica, resultante da consciência de os problemas educacionais brasileiros serem problemas sociais e não apenas pedagógicos, cuja solução não depende só de reformas escolares. É uma concepção que intelectuais brasileiros não diretamente preocupados com a escola têm defendido mais que os educadores, talvez por ressaltarem outras variáveis intervenientes no processo de educação escolar e por atingirem, em suas análises dos problemas nacionais, níveis mais profundos da realidade social. No setor das pesquisas

\footnotetext{
${ }^{53}$ Ibidem, p. 39-40.

${ }^{54}$ Ibidem, p. 45.
} 
educacionais, também se reflete aquela concepção estreita dos problemas educacionais: vêm elas em geral focalizando somente as variáveis intra-escolares, tentando compreender a escola pela escola, destacando-a de modo arbitrário do contexto social, econômico e cultural em que se insere"

Fernando de Azevedo, no mesmo Simpósio, colabora com a discussão das relações entre mudança cultural e educação com a idéia de que uma mudança somente atinge a escola quando já atingiu a sociedade, de fato ou potencialmente. Para o autor, a escola deve acompanhar de perto a evolução social, se não quiser se desarticular do complexo social em que está inserida: "É esse, de fato, o papel que pode exercer a educação organizada em face das mudanças sociais, o de contribuir não para promovê-las, mas para torná-las efetivas e enraizá-las para ordená-las e até certo ponto encaminhá-las e dirigi-las" ${ }^{\text {"56 }}$.

$\mathrm{O}$ autor considera a possibilidade da educação operar como um agente de mudança cultural:

"A educação organizada, em que predominem o cultivo, intenso e extensivo, das ciências e o desenvolvimento do espírito crítico e experimental, pode constituir-se num instrumento de transformações técnicas e, em consequência, de mudança social". (...) É dentro desses limites que a educação organizada e em grande escala, atuando sobre as massas na formação das elites dirigentes, assume ou pode assumir, em condições determinadas, um papel mais ou menos importante na modificação da cultura e se torna capaz, até certo ponto, de estimular e favorecer as mudanças sociais ${ }^{, 57}$.

Em 1959 e 1960, o Departamento de Estudos e Pesquisas Sociais do CBPE concentrou suas atividades no estudo dos processos de industrialização e urbanização que vinham ocorrendo na sociedade brasileira. Darcy Ribeiro era o diretor da DEPE e convidou os intelectuais vinculados ao CRPE/SP para colaborar com o projeto.

Concentrando-se na análise dos problemas decorrentes do processo de industrialização vivido pela cidade de São Paulo, Florestan Fernandes afirma que "o desenvolvimento econômico criou, nela, condições mais propícias à expansão da sociedade de classes, ao funcionamento da democracia e à constituição de um sistema educacional complexo, suscetível de servir como um canal de peneiramento e de ascensão sociais" ${ }^{\text {"58 }}$.

A educação seria um elemento que contribuiria para o reajustamento do homem às novas situações sociais:

\footnotetext{
${ }^{55}$ Luiz PEREIRA, Rendimento e deficiências do ensino primário brasileiro, Estudos e Documentos, vol. 6, p. 234.

${ }^{56}$ Fernando de AZEVEDO, Educação e mudança social, Estudos e Documentos, vol. 6, p. 140.

${ }^{57}$ Ibidem, p. 149-50.
} 
"Certas instituições atuam uniformemente sobre a média da população e podem contribuir, mais que as outras, para formar o novo tipo de homem que a cidade está necessitando, para assegurar-se continuidade de desenvolvimento. Embora estejamos longe de possuir o sistema educacional de que carecemos, é preciso que nos habituemos a pensar na importância dele para o futuro da cidade" ${ }^{\text {. }}$.

Octávio Ianni, tratando da questão da democratização do ensino, publica um artigo em que destaca o grave "desajustamento" sofrido pela escola brasileira frente às necessidades da sociedade industrial:

"O fenômeno da demora social e cultural, que às vezes alcança de forma desastrosa determinadas instituições, envolveu-a [a escola] em grande parte. Em face dessa situação, a sociedade brasileira inegavelmente já dispõe de condições para encontrar as melhores soluções, levando em conta a emergência de configurações favoráveis em grupos sociais cada vez mais extensos e o destino fundamentalmente social da educação. Resta saber se os grupos restritos, vinculados a interesses imediatos $e$ estreitos, e que lutam conta a democratização da escola, não conseguirão postergar ainda mais as reformas urgentes em debate $" 60$.

Octavio Ianni defendia a idéia de que a escola é uma instituição social básica nas comunidades urbanizadas e, portanto, deve transformar-se continuamente "de modo a estar sempre em condições de preparar futuros cidadãos para uma sociedade em que estes especialmente irão viver, e não para aquela que também nós reconhecemos transitória ou já anacrônica em alguns de seus componentes" ${ }^{\prime 61}$.

A revista Pesquisa e Planejamento, de 1962, tem como tema principal de seus artigos a relação entre desenvolvimento econômico, mudança cultural e educação.

O artigo de apresentação destaca a forma como este tema seria abordado pela revista:

"As rápidas mudanças sociais do Brasil, parte das transformações que ocorrem em todo o mundo, estão a evidenciar a necessidade de um sistema educacional que seja um processo em constante evolução, diverso em cada meio, a fim de atender as necessidades presentes de cada região, de cada comunidade, de cada indivíduo, e que, a mesmo tempo, prepare todos para levar adiante o surto atual de progresso" ${ }^{, 62}$.

Jayme Abreu, em artigo publicado nesta revista, analisa a relação educaçãodesenvolvimento:

"A educação há de acompanhar, contemporaneamente, o processo de desenvolvimento, que cria conteúdos da cultura, os quais, para cada ciclo, devem constituir matéria da educação. Nessa tensão dialética de implicações recíprocas, a

\footnotetext{
${ }^{58}$ Florestan FERNANDES, O homem e a cidade-metrópole, Educação e Ciências Sociais, n. 11, p. 30.

${ }^{59}$ Ibidem, p. 41.

${ }^{60}$ Octavio IANNI, Condições sociais do ensino democrático, Educação e Ciências Sociais, n. 12, p. 71.

${ }^{61}$ Ibidem, p. 72.

${ }^{62}$ APRESENTAÇÃO, Pesquisa e Planejamento, n. 5, p. 03.
} 
educação reage sobre o processo de desenvolvimento, retardando-o, se anacrônica, acelerando-o, se oportuna",63.

Analisando as mudanças econômicas que aconteceram durante o Governo Juscelino Kubitschek, Octavio Ianni também fez considerações a respeito da educação brasileira:

"O contínuo e acelerado crescimento econômico, revelado em particular na política de eliminação dos pontos de estrangulamento da estrutura capitalista em instauração e no incentivo à expansão da produção industrial, tem criado exigências novas, que as instituições estruturadas em moldes tradicionais não têm possibilidades de atender. (...) O sistema brasileiro de ensino mostra-se incapaz de atender aos reclamos da expansão das condições urbano-industriais de existência; no estado em que se encontra, transformou-se num obstáculo institucional grave tanto ao crescimento como à democratização (...). Por isso é que a questão educacional se converteu num dos grandes temas do presente, ocasionando o aparecimento de um vigoroso movimento de opinião pública nos principais centros culturais do País" ${ }^{\text {64 }}$.

Octavio Ianni defende a transformação do ensino para que ele atenda às exigências do desenvolvimento econômico-social e às exigências de formação de personalidades democráticas. Esses dois processos, interdependentes, conduziriam a uma ordem social de caráter democrático, onde o indivíduo se tornaria cidadão:

"É preciso que se destruam ideais da antiga civilização agrário-comercial, onde se preconizava a formação falsamente humanística, apoiada numa cultura geral estéril, decorativa, que somente servia à preparação dos líderes e ideólogos dos grupos dominantes. A cátedra vitalícia, a farsa da cultura geral, o bacharelismo retórico, a preservação e ampliação do ensino privado, os currículos inadequados à formação de profissionais e pesquisadores competentes - esses são alguns dos remanescentes de um ensino tradicional orientado no sentido de formar 'elites' divorciadas das 'massas', às quais nada ou muito pouco se dá,"65.

\subsection{Comentários sobre o tema.}

Para Marcus Vinicius da Cunha tanto os artigos publicados pela revista Educação e Ciências Sociais, quanto os publicados na revista Pesquisa e Planejamento, no período de 1956 a 1960, apresentam o Brasil como um país em desenvolvimento: "o processo de industrialização e urbanização, acompanhado do avanço da forma política da democracia, impõe que o sistema escolar seja revisto, de modo a se adequar a essa nova realidade"66.

Libânia Nacif Xavier aponta a temática da mudança social como uma preocupação de fundo que instigava os cientistas sociais da época. Estudando os artigos da revista Educação e

\footnotetext{
${ }^{63}$ Jayme ABREU, Educação e desenvolvimento sócio-econômico da América Latina, Pesquisa e Planejamento, n. 5 , p. 20.

${ }^{64}$ Octavio IANNI, Educação e Mudanças Institucionais, Pesquisa e Planejamento, n. 5, p. 49.

${ }^{65}$ Ibidem, p. 51.

${ }^{66}$ Marcus Vinicius da CUNHA, Indivíduo e Sociedade no ideário escolanovista (Brasil: 1930-1960), p. 161.
} 
Ciências Sociais a autora afirma que "a temática da mudança social explicitava-se também nas pesquisas que buscavam identificar as mudanças de atitudes e valores que acompanhavam as transformações provocadas pelo desenvolvimento econômico e pela complexificação da sociedade"67. Para Libânia Nacif Xavier, nos anos 50, "uma parcela significativa da intelectualidade brasileira dedicou-se a estudar e compreender o processo de mudança que anunciava uma espécie de transição de um país de feitio rural para uma sociedade de caráter urbano e industrial" ${ }^{\prime 68}$.

Marcos Cezar de Freitas afirma que o projeto dos Centros Regionais reanimava o debate sobre os "dois brasis". No contexto do Centro Brasileiro de Pesquisas Educacionais, a pesquisa educacional que se somava à pesquisa sociológica e antropológica buscava conhecer a realidade nacional de um país dual, a ser unificado ${ }^{69}$. No contexto do Centro Regional paulista, “desejava-se explicitar os motivos pelos quais os 'fenômenos de demora cultural' e a 'tendência à inércia da cultura brasileira' incidiam sobre a esfera urbana, gerando o mesmo imobilismo do mundo rural, que ainda permanecia à mercê do passado"70. Marcos Cezar de Freitas exemplifica essa tendência a tomar a realidade urbana como objeto de análise dos pesquisadores do CRPE/SP, com o trabalho de Luiz Pereira apresentado no Simpósio de 1959. Nele, Luiz Pereira demonstra que os "dois brasis existiam não somente na distância entre o litoral e o sertão mas, substancialmente, na dificuldade que a cultura urbana encontrava em fazer-se vetor de racionalização do país como um todo, para o que a escola deveria tornar-se uma racionalizadora de cada comunidade em particular,"71.

\section{Pesquisa Científica e Planejamento Educacional.}

A idéia que orientou a criação do Centro Brasileiro e dos Centros Regionais de Pesquisas Educacionais era a de fundar em bases científicas a reconstrução educacional brasileira. Para realizar esse ideal, seria necessário o desenvolvimento de estudos educacionais e sociais através de métodos objetivos e, sempre que possível, experimentais. A reconstrução educacional do país dependeria do planejamento, cientificamente elaborado, das atividades de administração, organização e execução escolares.

\footnotetext{
${ }^{67}$ Libânia Nacif XAVIER, Por que não lemos Anísio Teixeira?, p. 93-4.

${ }^{68}$ Libânia Nacif XAVIER, O Brasil como laboratório: educação e ciências sociais no projeto dos Centro Brasileiro de Pesquisas Educacionais, p. 68.

${ }^{69}$ Marcos Cesar de FREITAS, Da idéia de regional no projeto do Centro Regional de Pesquisas Educacionais de São Paulo, p. 08.

${ }^{70}$ Ibidem, p. 31.

${ }^{71}$ Ibidem, p. 39.
} 
Uma definição de planejamento pode ser encontrada no material publicado na revista Educação e Ciências Sociais a respeito do Seminário Interamericano de Planejamento Integral da Educação ${ }^{72}$ (Washington, junho de 1958). Nessa reunião, o planejamento foi definido como "a previsão racional de todas as finalidades, implicações, participações, recursos, técnicas e consequências de um empreendimento e a programação das atividades, em fases definidas, que levem aos resultados desejados" ${ }^{, 73}$. O planejamento racional era considerado uma consequência necessária da utilização de métodos científicos no estudo de questões educacionais. Além disso, a urbanização e industrialização da sociedade determinariam a necessidade de uma política racionalmente planejada na condução desses assuntos.

Uma vez admitidas as considerações acima, os Centros de Pesquisas Educacionais funcionariam "como os olhos e o cérebro do planejamento, para dar-lhe racionalidade objetiva, instrumentação fundamental. Assim como os conceitos de democracia e educação são indissociáveis, na idéia de planejamento está indissociavelmente contida a idéia de pesquisa científica, objetiva" ${ }^{74}$.

\subsection{Pesquisa científica aplicada à educação.}

Fernando de Azevedo tratou da questão da pesquisa científica aplicada à educação em várias oportunidades. Ele caracterizava o trabalho do Centro como "uma tentativa de penetração do espírito e dos métodos científicos na esfera da educação pela utilização sistemática das técnicas de pesquisa, histórica, bio-psicológica, social e educacional ao estudo e à solução prática de seus problemas”75. Para Fernando de Azevedo, “(...) não há meio mais eficaz para reduzir a margem de erros e encaminhar-nos a uma compreensão tão clara quanto possível das realidades que tenhamos de operar do que pesquisas de toda ordem, em grande escala e metodicamente conduzidas" ${ }^{, 76}$.

Tratando do problema do caráter científico das atividades educacionais, Anísio Teixeira afirma:

"Não se trata, pois, de criar propriamente uma 'ciência da educação', que no sentido restrito do termo, como ciência autônoma, não existe nem poderá existir, mas de dar condições científicas à atividade educacional, nos seus 3 aspectos fundamentais: de

\footnotetext{
72 Jayme Abreu (DEPE/CBPE) e Carlos Mascaro (Professor de Administração Escolar da USP) participaram deste evento.

${ }^{73}$ SEMINÁRIO Interamericano de Planejamento Integral da Educação, Educação e Ciências Sociais, n. ${ }^{\circ}$ 8, p. 151.

${ }^{74}$ Ibidem, p. 152 (grifos meus).

${ }^{75}$ Fernando de AZEVEDO, Luz nova sobre os caminhos, Pesquisa e Planejamento, n. 1, p. 16.

${ }^{76}$ Fernando de AZEVEDO, Inauguração do CRPE, Pesquisa e Planejamento, n. 1, p. 08.
} 
seleção de material para o currículo, de métodos de ensino e disciplina, e de organização e administração das escolas.(...)Os nossos Centros de Pesquisa Educacional se organizam, assim, num momento de revisão e tomada da consciência dos progressos do tratamento científico da função educativa e, por isso mesmo, têm certa originalidade" ${ }^{77}$.

Para Florestan Fernandes, a distância entre o saber científico e o saber prático poderia ser destruída por intermédio das ações planificadas, uma vez que o planejamento dá primazia ao conhecimento das técnicas de controle racional das situações práticas. Em relação ao planejamento educacional, o autor afirma que "a nossa capacidade de lidar com os problemas educacionais do presente e de resolvê-los de modo mais eficiente depende, diretamente, do sucesso que tivermos em utilizar os dados da ciência no planejamento das atividades educacionais" ${ }^{, 78}$. Nesse sentido, o autor aponta para o importante papel que pode ser desenvolvido pelos Centros de Pesquisa Educacionais, introduzindo o planejamento na esfera da educação sistemática no Brasil e conferindo ao sociólogo a responsabilidade de colaborar com os educadores nas fases de elaboração e de aplicação de planos de controle educacional.

\subsection{Diversos aspectos do planejamento educacional.}

Anísio Teixeira, no discurso proferido na abertura do curso para formação de especialistas em educação, realizado no CRPE/SP, defendeu a idéia de que a democratização do ensino está vinculada à necessidade de planejamento da educação:

"Não podemos selecionar os alunos. Temos que educar a todos. Não podemos selecionar os mestres. Temos de escolhê-los em camadas cada vez mais comuns. Com alunos comuns e mestres comuns, cresceram as necessidades de planejamento, as necessidades de supervisão e as necessidades de administração" ${ }^{\text {,79. }}$.

Anísio Teixeira também destacou o fato de que a democratização do ensino não ocorreu sozinha, houve uma mudança nos objetivos da educação escolar. Já não bastava preparar estudiosos e intelectuais:

"Também temos que preparar a grande massa de meninos e jovens para as tarefas comuns da vida, tornadas técnicas senão difíceis, pelo tipo de civilização que se desenvolveu em consequência de nosso progresso em conhecimento, e, além disto, os quadros vastos, complexos e diversificados das profissões e práticas em que se expandiu o trabalho especializado" 80 .

\footnotetext{
${ }^{77}$ Anísio TEIXEIRA, Ciência e Arte de Educar, Pesquisa e Planejamento, n. 1, p. 69-78.

${ }^{78}$ Florestan FERNANDES, A ciência aplicada e a educação como fatores de mudança social provocada, Estudos e Documentos, vol. 5, p. 42.

${ }^{79}$ Anísio TEIXEIRA, Por que especialistas em Educação?, Educação e Ciências Sociais, n. 7, p. 06.

${ }^{80}$ Ibidem, p. 06.
} 
Essas mudanças teriam gerado a necessidade do planejamento educacional, que envolveria os seguintes elementos:

“a seleção dos conhecimentos teóricos adequados aos novos fins da educação; a formulação de conhecimentos práticos, antes confiados à espontaneidade da vida e do trabalho; a fusão, conjugação e coordenação de conhecimentos especializados em 'todos' globalizados, aptos a interessarem e serem compreendidos pelo aluno comum; o estudo das dificuldades desses alunos e dos recursos para vencê-las; e, todo um trabalho de administração complexo, diversificado e difícil",81.

Em relação à questão do planejamento, Fernando de Azevedo acreditava que "a educação não poderá subsistir nem desenvolver-se se não for apoiada numa sólida armadura administrativa e na amplitude e na segurança de um largo e vigoroso equipamento culturalcientífico, de técnicas, pesquisas e planificação. É para isso que se criaram entre tantas outras iniciativas, os CRPEs" ${ }^{\prime \prime 2}$.

Malcolm Adiseshiah, subdiretor geral da UNESCO, no discurso de abertura do I Curso de Especialistas em Educação, também abordou a questão da necessidade de planificação: "O planejamento educacional leva à adaptação da educação às necessidades da comunidade e às diferenças individuais. Ambos os assuntos são essenciais para uma formulação realística da política educacional" ${ }^{\prime 83}$.

Em relação à questão do planejamento educacional, Jayme Abreu destacava que as realizações nesse sentido que iniciaram-se com a Reunião Interamericana de Ministros da Educação, realizada em Lima, no Peru, em maio de 1956, e com o Seminário Interamericano de Planejamento Integral da Educação, realizado em Washington, nos Estados Unidos, em junho de 1958. Nessas reuniões destacou-se a necessidade de aumentar, de forma planejada, a educação na América Latina, sendo que o planejamento educacional deveria ser integrado ao planejamento sócio-econômico. "Do ângulo econômico, pode-se afirmar que não lograrão realização satisfatória os planos de aceleração do desenvolvimento que se prevêem para a América Latina, sem um correspondente desenvolvimento planejado da educação, que assegure a formação de todo o pessoal necessário" 84 .

Para Jayme Abreu, o planejamento educacional surge como uma opção em relação à antiga doutrina do laissez-faire que não conseguiu se auto-regular adequadamente:

\footnotetext{
${ }^{81}$ Ibidem, p. 07.

${ }^{82}$ Fernando de AZEVEDO, Teoria e experiência educativa, Pesquisa e Planejamento, n. 2, p. 35.

${ }^{83}$ Malcolm S. ADISHESIAH, A UNESCO e a luta contra o analfabetismo, Pesquisa e Planejamento, n. 2 , p. 64.

${ }^{84}$ Jayme ABREU, Educação e desenvolvimento sócio-econômico da América Latina, Pesquisa e Planejamento, n. 5 , p. 21.
} 
"Precisa o Brasil deixar, urgentemente, a fase a que chamaríamos dos pensamentos desejosos em educação, das vaguidades impressionistas, dos subjetivismos gratuitos das nossas pitonisas educacionais, para ingressar na era do planejamento educacional racionalmente estabelecido, partindo da hierarquização de prioridades lastreada por uma filosofia educacional consequente e chegando aos projetos, tecnicamente elaborados, como etapa final do planejamento" ${ }^{~}$. $^{2}$

Renato Jardim Moreira, diretor da Divisão de Estudos e Pesquisas Sociais do CRPE/SP, publicou um importante artigo na revista Pesquisa e Planejamento, onde discute o planejamento educacional para o Estado de São Paulo, tomando como base de informações os dados obtidos através do Levantamento do Ensino Primário realizado pelo CRPE/SP.

Para esse autor, "a organização do planejamento deve estabelecer um processo que leve à intervenção em todos os setores do ensino e não apenas naqueles que apresentam problemas imediatos mais salientes" ${ }^{\text {" }}$. Segundo Renato Jardim Moreira, haveria a necessidade de se desenvolver o chamado "planejamento integral da educação":

"A intervenção, para ser bem sucedida, deve ser orientada por um planejamento integral da realidade educacional. Na falta deste, não há dúvida que se pode pensar, para efeitos executivos imediatos, em planejamentos parciais, que se refiram a determinados campos e problemas. A longo termo, à medida que se for definindo o planejamento integral, os planejamentos parciais irão se tornando mais dependentes do geral, até passarem a corresponder efetivamente às suas diferentes partes. Por assim dizer, os planejamentos parciais fluirão no planejamento integral, que só poderá ser estabelecido a partir dos resultados de levantamentos e de pesquisas ${ }^{, 87}$.

Defendendo a mesma idéia, Joanna Mader Elazari Klein (DEPS-CRPE/SP) acreditava que o planejamento integral da educação deveria ser "calcado na conciliação entre as condições sociais que a escola precisa atender, o conhecimento objetivo da realidade escolar em que se pretende intervir e a qualificação do pessoal de que se pode dispor" ${ }^{\prime 8}$. Para a autora, a solução dos problemas educacionais brasileiros pressupunha a existência de um planejamento integral da educação.

\subsection{Os levantamentos e o planejamento educacional.}

\footnotetext{
${ }^{85}$ Ibidem, p. 40.

${ }^{86}$ Renato Jardim MOREIRA, Planejamento Educacional para o Estado de São Paulo, Pesquisa e Planejamento, n. 4 , p. 07.

${ }^{87}$ Ibidem, p. 08.

${ }^{88}$ Joanna Mader Elazari KLEIN, Subsídios para um planejamento da inspeção do ensino primário, Pesquisa $e$ Planejamento, n. 4, p. 26.
} 
Na comunicação que fez no Simpósio de 1959, Renato Jardim Moreira tratou principalmente da elaboração de levantamentos e sua utilidade na realização de um planejamento integral da educação.

Renato Jardim Moreira afirma que "o conhecimento existente sobre a realidade educacional brasileira, ponto de partida para a investigação científica de seus problemas, é principalmente de natureza estatística» ${ }^{\Perp 99}$. A análise desses conhecimentos existentes, permitiria a sugestão da forma que a investigação social deveria assumir para atender ao conhecimento atual e aos seus próprios fins.

Renato Jardim Moreira esclarece que os dados disponíveis sobre o sistema educacional brasileiro resultam do Plano de Estatísticas Educacionais, de 1931, elaborado com o objetivo de fornecer uma visão geral da situação educacional, numa época em que as técnicas de amostragem estavam iniciando seu desenvolvimento. Portanto, esses dados não atendem às condições necessárias ao planejamento de amostras. Um exemplo dessa situação é dado pelo Estado de São Paulo: não existia uma relação completa de escolas. Em 1958, estavam cadastradas, no município de São Paulo, apenas 79 escolas primárias particulares, com 6.200 alunos matriculados. No Cadastro de Escolas do CRPE/SP constavam 50.000 matrículas nesse tipo de ensino, no mesmo ano.

Dentre os estudos que utilizam os dados fornecidos pela estatística, o autor destaca aqueles que diagnosticam os problemas da educação brasileira e traçam as linhas gerais de uma política educacional para corrigi-los. Os documentos típicos dessa forma de análise foram os Manifestos dos Educadores de 1932 e de 1959. "São essas análises programáticas que estabeleceram um consenso a respeito dos problemas relevantes da educação e definiram, na medida em que usam determinados dados, os aspectos significativos sobre os quais a estatística deve informar" ${ }^{\circ 0}$.

Considerando a necessidade de se conhecer melhor os aspectos gerais do sistema educacional brasileiro, o autor defende a existência de um compromisso entre o planejamento da ação política e a investigação social, conforme foi estabelecido na própria organização institucional dos Centros de Pesquisas Educacionais.

\footnotetext{
${ }^{89}$ Renato Jardim MOREIRA, A investigação social diante dos problemas educacionais brasileiros, Estudos $e$ Documentos, n. 5, p. 105.

${ }^{90}$ Ibidem, p. 108-9.
} 
A parte seguinte da exposição destina-se a "demonstrar a possibilidade de se obter um conhecimento da realidade educacional que satisfaça, ao mesmo tempo, as solicitações da administração escolar e os requisitos da pesquisa científica" ${ }^{\text {91 }}$.

Esse conhecimento, capaz de colaborar para o planejamento de uma política educacional, possui características próprias que o distinguem do que normalmente é valorizado como sendo de natureza científica: "não precisa ser exaustivo, mas apenas fornecer os elementos suficientes para o planejamento da ação política; não precisa ser original quanto à sua matéria; ao se realizar a pesquisa para obtê-lo, não deve haver preocupação de que ele venha a representar uma contribuição teórica, nem de se empregarem técnicas originais"92. As preocupações do pesquisador concentram-se aperfeiçoar os instrumentos e processos de coleta e análise de dados e, também, em estudar determinados problemas com objetivos teóricos, através de materiais coligidos com finalidades práticas.

Para Renato Jardim Moreira, o levantamento (survey) era o tipo de investigação que atenderia às características apresentadas acima e, além disso, teria a vantagem de fornecer rapidamente as informações solicitadas, ponto fundamental quando decisões devem ser tomadas a tempo de gerar resultados práticos.

Os levantamentos, utilizados frequentemente pelas ciências sociais, seriam ideais para atender àqueles pesquisadores interessados na aplicação prática dos trabalhos científicos. $\mathrm{O}$ instrumento utilizado para a coleta de dados é, geralmente, o questionário e trabalha-se com uma amostra da população estudada. Renato Jardim Moreira acrescenta que "pelo vulto do trabalho e por ser complexa a realidade a que se refere, exige a formação de equipes numerosas com especialistas em vários campos das ciências sociais e nos diversos tipos de atividades necessárias à sua realização" "93.

Essa necessidade de organização de grandes equipes, muitas vezes, torna o levantamento uma técnica que gera gastos elevados, entretanto:

“(...) essa limitação é contornada quando a administração pública está interessada no conhecimento científico dos problemas educacionais e instala, e mantém, instituições do tipo do CBPE e Centros Regionais de Pesquisas Educacionais. Essa organização, cujo objetivo é realizar os estudos e pesquisas que forneçam elementos para a reconstrução educacional do País, tem a possibilidade de obter recursos necessários para o financiamento da pesquisa no campo da educação"94.

\footnotetext{
${ }^{91}$ Ibidem, p. 109.

92 Ibidem, p. 110.

${ }^{93}$ Ibidem, p. 111.

94 Ibidem, p. 115.
} 
Em relação às críticas que as investigações através de levantamentos sofreram, Renato Jardim Moreira afirma:

"Somente quando já se tiver um conhecimento ponderável de vários aspectos gerais da educação, é que se poderá e se deverá pensar em procedimentos e análises mais refinados das ciências sociais. Será então a vez da entrevista, do estudo de casos, da observação e de todo o conjunto de técnicas sociológicas, antropológicas $e$ psicológicas, até que se atinja, em alguns setores, a experimentação"95

Através dos levantamentos se atenderia, de imediato, às necessidades da administração escolar e, a longo prazo, com um processo contínuo de pesquisas integradas, aos padrões ideais do trabalho científico.

\subsection{Comentários sobre o tema.}

Para Marcus Vinicius da Cunha, existia no CRPE/SP "uma grande ênfase na idéia de planejamento racional e objetivo das mudanças julgadas necessárias à estrutura do ensino, de modo a sintonizá-lo com o programa de desenvolvimento do país. A técnica de levantamentos era muito empregada como meio para obtenção de dados a respeito da educação no Estado de São Paulo"96. O autor destaca que "para que se efetue a adequação da escola às necessidades sociais, entende-se que as mudanças devam ser planejadas de modo racional e objetivo, o que significa serem calculadas cientificamente" ${ }^{\text {97 }}$. Além disso, "o planejamento científico visa a superar os fatores subjetivos que envolvem o trabalho docente. A prática pedagógica, embora não possa prescindir do elemento humano, deve se fundamentar sempre numa técnica claramente formulada, ao invés de se deixar conduzir pelo improviso e pelas flutuações de personalidade do mestre" $"$. A respeito dos surveys realizados, Marcus Vinicius da Cunha acrescenta: "o método de levantamentos, empregado para a obtenção de dados a respeito do ensino, consiste em apreender informações quanto à realidade imediatamente observável, o que possibilita o planejamento racional das mudanças almejadas" $" 99$.

Segundo Libânia Nacif Xavier, "a importância do planejamento educacional foi tema a que se dedicaram os educadores que ocuparam cargos hierárquicos no CBPE. Anísio Teixeira, Roberto Moreira e Jayme Abreu, entre outros, publicaram artigos sobre o tema, demonstrando

\footnotetext{
${ }^{95}$ Ibidem, p. 115.

${ }^{96}$ Marcus Vinicius da CUNHA, Indivíduo e Sociedade no ideário escolanovista (Brasil: 1930-1960), p. 181-2.

${ }^{97}$ Ibidem, p. 207.

${ }^{98}$ Ibidem, p. 207-8.

${ }^{99}$ Ibidem, p. 208.
} 
a centralidade da questão, mais nitidamente delineada no início dos anos 60"100 . A autora destaca que, "o Planejamento passou a constituir, na visão dos educadores e sociólogos que atuaram no Centro [CBPE], o símbolo organizatório da civilização em mudança. Pelo alto grau de racionalidade permitido pela planificação, esperava-se extrair desta condições para interferir no rumo das mudanças que se processavam no país. Daí o esforço teórico, político e prático, empreendido nesse sentido" $" 101$.

Clarice Nunes, ao destacar a habilidade de estrategista de Anísio Teixeira, informa que o Centro Brasileiro e os Centros Regionais não se destinavam apenas a produzir pesquisas, mas sobretudo, "a oferecer, através dos resultados dessas pesquisas, subsídios para um planejamento educacional" ${ }^{\text {102 }}$. Para a autora, o contato com as idéias de John Dewey forneceu a Anísio Teixeira "um guia teórico que combateu a improvisação e o autodidatismo, abriu a possibilidade de operacionalizar uma política e criar a pesquisa educacional no País ${ }^{103,}$.

\section{A tramitação da Lei de Diretrizes e Bases da Educação Nacional.}

Ao mesmo tempo em que criava os Centros de Pesquisas Educacionais, Anísio Teixeira discutia os problemas da escola primária brasileira e da formação de professores. Em 1952, quando tomava posse na diretoria do INEP, Anísio Teixeira defendeu a utilização de métodos científicos no trato das questões educacionais e afirmou que a ciência forneceria o "itinerário" a ser percorrido pelos pesquisadores. Esse itinerário estaria em constante reconstrução, mas teria uma "unidade de essência, fins e objetivos"104 expressa na Lei de Diretrizes e Bases e na consciência profissional dos educadores.

Em um artigo de 1957, em que criticava o projeto de lei orgânica do ensino secundário, Jayme Abreu voltaria à questão de aprovação da LDBEN. A crítica de Jayme Abreu referia-se à elaboração de uma lei fragmentária, que visava apenas uma aspecto parcial da educação, antes de se formular uma lei de diretrizes e bases que sistematizaria toda a educação brasileira. O autor relata que a Associação Brasileira de Educação desaprovou tanto

\footnotetext{
${ }^{100}$ Libânia Nacif XAVIER, O Brasil como laboratório: educação e ciências sociais no projeto dos Centro Brasileiro de Pesquisas Educacionais, p. 196-7.

${ }^{101}$ Ibidem, p. 92.

102 Clarice NUNES, Anísio Teixeira, Dicionário de Educadores no Brasil, p. 62.

${ }^{103}$ Ibidem, p. 58-9.

${ }^{104}$ OS ESTUDOS e as pesquisas educacionais do Ministério da Educação e Cultura, Educação e Ciências Sociais, n. 1, p. 16.
} 
o projeto de lei orgânica do ensino secundário, quanto a prioridade que se deu à elaboração dessa "legislação fragmentária e parcial"105 em detrimento da LDBEN.

Em relação à demora em se aprovar definitivamente a Lei de Diretrizes e Bases, Jayme Abreu fez o seguinte comentário:

"O que tem ocorrido, essencialmente, é a atuação de grupos de pressão organizados, mais atuantes do que numerosos e a influência pessoal de certos líderes políticos muito fixados a pontos de vista pessoais, logrando êxito sobre grupos menos atentos, mais displicentes, mais vacilantes, ou sem liderança legislativa eficaz, face ao problema. Nesses grupos de pressão pode ser identificada a atuação de uma certa burocracia, ciosa de preservar áreas de mando e prestígio, interesses de empresários do ensino e reivindicações de profissionais desse campo, assustados com certos equívocos quanto a uma imaginária restrição de oportunidades de trabalho, decorrente de visão parcial de certas medidas preconizadas. O que não encontrará, todavia, é a opinião da clientela discente, vítima dessa organização educacional, tampouco a dos setores sociais que utilizam o produto dessas escolas" ${ }^{106}$.

Em 1958, as discussões sobre a LDBEN se intensificam. No Editorial da revista Educação e Ciências Sociais de dezembro desse ano, Anísio Teixeira criticava a falta de profundidade e o excessivo prolongamento no tempo do debate a respeito da aprovação dessa Lei. Para ele, a Lei não deveria pretender esgotar o assunto, mas ser um "estatuto que disponha a respeito dos deveres do Estado em relação à educação formal dos cidadãos”"107.

Sobre o propósito da Lei de Diretrizes e Bases, Anísio Teixeira esclarece:

"A lei em educação não é, em rigor, uma lei de educação mas sobre educação. $O$ Estado legisla sobre educação como legisla sobre saúde, sobre agricultura, sobre indústria. Como o interesse pela educação se fez público, isto é, transformou-se em um interesse dominante de toda a sociedade, o Estado é convocado a estabelecer as bases e diretrizes, dentro das quais vai intervir no processo e assegurar que as oportunidades educativas se desdobrem regularmente, obedecendo certas condições de justiça e com a eficiência necessária para que todos delas se possam aproveitar. (...) As diretrizes da educação seriam o desenvolvimento do que já se acha contido na Constituição e as bases importariam na fixação das competências e poderes educacionais da União, dos Estados e dos Municípios, dos órgãos pelos quais esses poderes se exerceriam e dos recursos a serem aplicados no desenvolvimento dos serviços públicos de educação" ${ }^{\text {,108. }}$.

Anísio Teixeira acreditava, em 1958, que a LDBEN deveria adotar o seguinte sistema de administração e financiamento da educação:

\footnotetext{
${ }^{105}$ Jayme ABREU, Observação preliminares a respeito do Projeto 4.132 C, de 1954, que dá novo texto à lei orgânica do ensino secundário brasileiro, Educação e Ciências Sociais, n. 5, p. 233.

${ }^{106}$ Ibidem, p. 237-8.

${ }^{107}$ Anísio TEIXEIRA, Sobre o debate em torno da Lei de Diretrizes e Bases da Educação, Educação e Ciências Sociais, n. 9, p. 05.

${ }^{108}$ Ibidem, p. 05-6.
} 
"A minha sugestão seria a de uma lei federal que fixasse as condições pelas quais a União e os Estados delegassem a função de administrar as escolas, no nível primário, a órgãos locais, na órbita municipal, e às próprias escolas no nível secundário e superior, mediante um sistema de financiamento triplo - da União, dos Estados e dos Municípios - graças ao qual se garantiria à União e aos Estados esse controle dos sistemas escolares sem, entretanto, chegar a impedir a experimentação, o crescimento e a liberdade" 109 .

O autor conclui suas considerações sobre a tramitação da LDBEN afirmando:

"Dispersada a neblina pedagógica e ideológica que nos impede, há onze anos, de elaborar uma lei de bases e diretrizes da educação nacional, passaríamos a votar uma lei de meios e de poderes, à maneira das leis tão revolucionárias que vimos votando no campo fiscal e financeiro, e nos lançaríamos à imensa experimentação educacional em um país grande como um continente e que constitui na América do Sul, o mais amplo laboratório de democracia de todo o hemisfério" $" 110$.

Nesse momento histórico, quando tramitava no Congresso a Lei de Diretrizes e Bases da Educação, travava-se uma luta entre os defensores da escola pública e os defensores da subvenção do Estado para as escolas privadas. O Deputado Carlos Lacerda apresentou um substitutivo ao projeto de lei que continha três pontos fundamentais: a) o ensino seria ministrado sobretudo pelas entidades privadas e, supletivamente, pelo poder público; b) o ensino particular não seria fiscalizado pelo Estado; e, c) o Estado subvencionaria as escolas privadas, a fim de que estas pudessem igualar os vencimentos dos seus professores aos dos professores oficiais.

Criticando diretamente esse substitutivo e defendendo a escola pública, Jayme Abreu fez as seguintes considerações:

“Sob a alegação de luta contra o 'monopólio estatal da educação', uma campanha ostensiva contra a escola pública brasileira vem e desenvolvendo nesses últimos tempos, à qual não devem estar desatentas as consciências liberais, republicanas $e$ democráticas do país. (...) Muito mais do que situações pessoais, o que se está pondo em perigo, são, efetivamente, princípios democráticos defendidos por educadores, no seu esforço por ampliar e conservar pública a educação pública, guardando-a como instrumento de toda uma cidadania para a realização de uma sociedade democrática $e$ não, como vem sendo tentado, pondo-a como serviço ancilar de instituições privadas, sectárias, de clientela de limitados estratos da sociedade" ${ }^{111}$.

A respeito da proposta de que o Estado subsidiasse as escolas privadas, Jayme Abreu comentou:

\footnotetext{
${ }^{109}$ Ibidem, p. 07.

${ }^{110}$ Ibidem, p. 09.

${ }^{111}$ Jayme ABREU, A luta contra a escola pública brasileira, Educação e Ciências Sociais, n. 9, p. 57.
} 
"O que sempre em verdade se desejou, no clima do privatismo tradicionalmente dominante na vida brasileira, foi por o Estado como servo e guardião de interesses de importantes grupos de pressão privados e investir contra ele na medida em que se considera já insuficientemente garantidos esses privilégios. Veja-se o típico desinteresse desses altos segmentos da sociedade brasileira pelo ingente problema nacional da escola primária. (...) Admitir que a grande expansão educacional brasileira se deva fazer, predominantemente, ou até exclusivamente, por intermédio de empresas privadas, substancialmente subsidiadas pelos recursos públicos, invertendo o que nossa constituição de estado democrático prescreve, é reacionarismo de evidente interesse privatista, do quilate daquele que em economia afirma que na fase presente do capitalismo internacional é possível a superação do subdesenvolvimento de países subdesenvolvidos, sem uma larga presença estatal, no processo básico desse desenvolvimento" $" 112$.

A revista Educação e Ciências Sociais publicou, em abril de 1959, e a revista Pesquisa e Planejamento, em junho de 1959, o Manifesto Mais Uma Vez Convocados ${ }^{113}$, redigido por Fernando de Azevedo, em defesa da renovação educacional e da escola pública, gratuita e universal.

Neste documento, publicado depois de 27 anos de divulgação do Manifesto dos Pioneiros da Escola Nova, de 1932, resgatam-se os ideais do movimento de reconstrução nacional. Os educadores que subscrevem o documento declaram:

"Não renegamos nenhum dos princípios por que nos batemos em 1932, e cuja atualidade é ainda tão viva, e mais do que viva, tão palpitante que esse documento, já velho de mais de 25 anos, se diria pensado e escrito nestes dias. Vendo embora com outros olhos a realidade, múltipla e complexa - porque ela mudou e profundamente sob vários aspectos - e continuando a ser homens de nosso tempo, partimos do ponto em que ficamos, não para um grito de guerra que soaria mal na boca de educadores, mas para uma tomada de consciência da realidade atual e uma retomada, franca e decidida, de posição em face dela e em favor, como antes, da educação democrática, da escola democrática e progressista que tem como postulados a liberdade de pensamento e a igualdade de oportunidades para todos",114.

Nesses termos, este documento refletia as idéias dos principais educadores e cientistas sociais brasileiros, muitos deles atuando no CRPE/SP, na Universidade de São Paulo ou no CBPE, como Fernando de Azevedo, Anísio Teixeira, Abgar Renault, Florestan Fernandes, Antonio Candido, Nelson Werneck Sodré, Laerte Ramos de Carvalho, Milton da Silva Rodrigues, José Arthur Giannotti, Maria José Garcia Werebe, Egon Schaden, Paschoal Lemme, Carlos Mascaro, Fernando Henrique Cardoso, Renato Jardim Moreira, Joel Martins,

\footnotetext{
${ }^{112}$ Ibidem, p. 60-1.

${ }^{113}$ Este Manifesto também foi publicado pelo jornal O Estado de S. Paulo, de 1. o de julho de 1959; pelo Diário do congresso nacional, de $1 .^{\circ}$ de julho de 1959; pela Revista Brasileira de Estudos Pedagógicos v. 31 n. ${ }^{\circ} 74$, de 1959; e, posteriormente, pelo Diário de Notícias e pelo Jornal do Comércio, do Rio de Janeiro.
} 
Darci Ribeiro, Jayme Abreu, Roberto Cardoso de Oliveira, Oracy Nogueira, Maria do Carmo Guedes, Aracky Kahvedjian, Celso de Rui Beisiegel, Álvaro Vieira Pinto, Ruth Cardoso, Silvia Maurer, Perseu Abramo, Frederico de Barros Brotero, José Mario Pires Azanha, Gabriel Bolaffi, Eugênio Cesar Bertoncini, Haydée Roveratti, e outros.

O Manifesto aponta os diversos problemas da educação pública brasileira, mas a defende frente aos setores que se opõem à sua existência e que eram representados pelos defensores da escola particular:

“A luta que se abriu, em nosso país, entre os partidários da escola pública e os da escola particular, é, no fundo, a mesma que se travou e recrudesce ora nesse, ora naquela país, entre a escola religiosa (ou o ensino confessional), de um lado, e a escola leiga (ou o ensino leigo), de outro lado. (...) Ela disfarça-se com frequência, quando não se apresenta abertamente, sob o aspecto de conflito entre a escola livre (a educação confessional) e a escola pública ou, para sermos mais claros, o ensino leigo, a cujo desenvolvimento sempre esteve historicamente ligado o progresso da educação pública. Mas, continuando a decomposição do problema em seus elementos principais, implica essa campanha contra a escola pública, se não é um dos fatores que a desencadearam, um aspecto econômico: é praticamente uma larga ofensiva para obter maiores recursos do Estado, do qual se reclama, não aumentar cada vez. mais os meios de que necessita o ensino público, mas dessangrá-lo para sustentar, com o esgotamento das escolas que mantém, as de iniciativa privada" "115

Contrapondo-se ao substitutivo Carlos Lacerda, os educadores argumentavam:

"A direita apoia, em geral, a escola livre, e a esquerda, a escola pública, e, por ter sido frequentemente assim, a tendência é de deslocar uma questão que se devia por em termos de interesse geral e acima de partidos, para o terreno de uma luta religiosa, devido às suas implicações confessionais, ou de uma luta entre grupos políticos, igualmente prejudicial ao debate do problema que temos o dever de examinar em face da Constituição Federal e conforme os princípios que regem as instituições democráticas. (...) Ora, somos todos os que assinamos esse Manifesto, educadores republicanos e democráticos, fiéis aos mais altos valores da tradição liberal. E, quando se trata de problemas como os da educação, entendemos que essa é 'uma das questões em cujo terreno (palavras de Rui Barbosa) são intrusas as paixões políticas $, ", 116$.

Os signatários do Manifesto também argumentam que o substitutivo é inconstitucional, pois na Constituição consta que o "ensino dos diferentes ramos será ministrado pelos poderes públicos, e é livre a iniciativa particular, respeitadas as leis que o regulem". O monopólio da educação pelo Estado não é defendido, mas sim a destinação de

\footnotetext{
${ }^{114}$ MANIFESTO dos Educadores, Pesquisa e Planejamento, n. 3, p. 76-7.

115 Ibidem, p. 84.

${ }^{116}$ Ibidem, p. 85-6.
} 
recursos públicos apenas às escolas públicas e a fiscalização, por parte do Estado, de todas as escolas.

No Manifesto defende-se a reestruturação da escola pública para que ela atenda às necessidades da sociedade brasileira. Essa renovação deveria ser feita através do Estado, para que fossem garantidos os direitos da população à educação universal, obrigatória e gratuita:

“As profundas transformações operadas em consequência da preponderância da economia industrial sobre as formas econômicas que a precederam, determinam, de fato, e têm de determinar, nos sistemas de ensino, grandes mudanças que permitam ampla participação de todos em estudos e práticas, desde a escola primária completa até os mais altos níveis de estudos superiores. Já se vê, mais uma vez, que essa participação, com a amplitude que deve ter, para colher toda a população em idade escolar, não pode ser senão obra do Estado, pela escola universal, obrigatória e gratuita, e numa sucessão de esforços ininterruptos, através de longos anos, inspirados por uma firme política nacional de educação" 117 .

No Manifesto percebe-se que os autores tinham consciência de que as disputas extrapolavam o limite do campo educacional para entrar em questões econômicas e ideológicas que exigiam a tomada de uma posição política definida por parte dos educadores:

"Na luta que agora se desfechou e para a qual interesses de várias ordens, ideológicos e econômicos, empurraram os grupos empenhados em sustentá-la, o que disputam afinal, em nome e sob a capa de liberdade, é a reconquista da direção ideológica da sociedade - uma espécie de retorno à Idade Média, e os recursos do erário público para manterem instituições privadas, que, no entanto, custeadas, na hipótese, pelo Estado, mas não fiscalizadas, ainda se reservariam o direito de cobrar o ensino, até a mais desenvolta mercantilização das escolas" $" 118$.

Foi publicado na revista Educação e Ciências Sociais de agosto de 1959, um artigo do jornal Última Hora (20 de março de 1959), no qual Anísio Teixeira, Darcy Riberio, Almir de Castro Raul Bitencourt e Jayme Abreu manifestam sua crítica ao substitutivo Carlos Lacerda e a defesa da escola pública e democrática.

No embate entre escola particular e escola pública que se travou no decorrer das discussões sobre a LDBEN, Anísio Teixeira defendia a escola pública como forma de diminuir as desigualdades e discriminações na sociedade brasileira:

"A escola pública não era apenas a escola para o pobre, no que resultaria, se fosse apenas uma extensão da escola privada às classes menos favorecidas, mas a escola destinada a fundar a república e a formar a consciência nacional. (...) A escola pública é a instituição que acompanha mais de perto o próprio desenvolvimento da nação. Nacionalismo e escola pública são termos correlatos. Um não existe sem a outra (...). Ela é a escola nacional, destinada a formar a consciência da nação, do

\footnotetext{
${ }^{117}$ Ibidem, p. 100.

${ }^{118}$ Ibidem, p. 100.
} 
mesmo modo que é a escola destinada a promover a igualdade social, a igualdade de oportunidades" 119 .

Contrário à idéia de subvenção das escolas privadas pelo Estado, Anísio Teixeira acreditava que essa manobra tinha o seguinte objetivo:

"Retardar o processo de democratização da sociedade brasileira e da integração da classe média no seio do povo brasileiro, todo ele um só povo, dividido em camadas sociais, é certo, mas percorridas todas elas pelo mesmo espírito e por vigorosa mobilidade, de que se constitui instrumento supremo exatamente a famosa 'escada educacional', isto é, um sistema educacional contínuo da escola primária à universidade e a todos aberto, ou seja, público. É este a todos, é este público, que a campanha do desvio de recursos públicos para a escola particular quer impedir, usando, para isto, até os argumentos da religião. Tenho pois razão em apontar e condenar a engenhosa solércia, com que nossa sociedade se defende contra as consequências dos próprios princípios, que tanto engrossa a voz em proclamar" ${ }^{\prime 20}$.

Em fevereiro de 1960 foram publicados, na revista Educação e Ciências Sociais, três manifestos contrários ao substitutivo do Deputado Carlos Lacerda: o manifesto elaborado pela União Estadual dos Estudantes (publicado pelo Jornal O Estado de S. Paulo, de 29 de janeiro de 1960), o manifesto elaborado pela Associação dos Antigos Alunos da FFCL da USP (O Estado de S. Paulo, 11 de fevereiro de 1960) e o manifesto dos alunos da FFCL da USP (O Estado de São Paulo de 31 de janeiro de 1960). Esses manifestos defendiam a escola pública como mecanismo de democratização da sociedade brasileira.

A 1. ${ }^{a}$ Convenção Estadual de Defesa da Escola Pública realizou-se em 1960, no auditório da Biblioteca Municipal de São Paulo, sob a presidência de Júlio de Mesquita Filho. Anísio Teixeira, nessa ocasião, apontava uma contradição no projeto que havia sido aprovado na Câmara e estava em tramitação no Senado: a principal característica do projeto era "conceder categoria pública ao ensino privado" "121, uma vez que o Estado subvencionaria o ensino particular. Com isso, o ensino privado deixaria de ser livre e passaria a aceitar o controle do poder público que, afinal, o sustentaria economicamente. Entretanto, a contradição reside no fato de que a escola privada desejava ser financiada pelo Estado, mas rejeitava o seu controle. Anísio Teixeira conclui: "A nossa Constituição, liberalmente, permite a existência da educação privada. Mas entre isto e promovê-la, e custeá-la, vai um abismo!" 122 .

\footnotetext{
${ }^{119}$ Anísio TEIXEIRA, A escola particular e a escola pública, Educação e Ciências Sociais, n. 12, p. 88-9.

${ }^{120}$ Ibidem, p. 93.

${ }^{121}$ Anísio TEIXEIRA, Tentativa de transação entre pontos de vista realmente antagônicos, Educação e Ciências Sociais, n. 14, p. 111.

${ }^{122}$ Ibidem, p.112.
} 
No contexto da Campanha de Defesa da Escola Pública, Florestan Fernandes manifestou sua indignação ao projeto de lei de diretrizes e bases:

"Existiam fundadas esperanças de que esse projeto de lei iria inaugurar uma nova era na vida educacional do país, fornecendo as bases para a reorganização do ensino primário, do ensino médio e do ensino superior, bem como a solução pelo menos dos problemas educacionais mais grave que enfrentamos. (...) O projeto de lei omitiu-se diante de todas essas necessidades e comprometerá terrivelmente, se for promulgado de modo definitivo, a nossa capacidade de resolvê-las no presente ou no futuro próximo. Ficou tão aquém das esperanças mais legítimas e do que deveria ser feito como mínimo, que representa um passo atrás, em relação à própria Constituição vigente, muito mais 'liberal' e 'progressista' nas disposições sobre a educação nacional" $" 123$.

Florestan Fernandes defende três pontos principais:

1. A educação deve ter como objetivo central a "qualidade e a eficácia do ensino" "124 . A defesa da escola pública fazia-se necessária porque num país subdesenvolvido e com poucos recursos para a educação a universalização do estudo somente seria possível com um ensino gratuito. Sua posição, portanto, não era contrária à escola particular, que deveria continuar funcionando, com qualidade, e atendendo à população que pudesse custeá-la.

2. O Estado somente deveria destinar seus recursos para as escolas públicas:

"Dados o caráter escasso desses recursos, a gravidade dos problemas educacionais brasileiros e a existência de um sistema de ensino público que carece de melhoria e de expansão, julgamos que a intervenção do Estado nos assuntos educacionais deve concentrar-se nas escolas criadas por sua iniciativa $e$ abertas, indistinta $e$ gratuitamente, a todos os candidatos de aptidões comprováveis" $" 25$.

3. Os problemas educacionais brasileiros deveriam ser incluídos no horizonte intelectual de todo cidadão brasileiro, para que ele, através dos mecanismos democráticos, tivesse condições de influenciar as decisões dos partidos e do Governo nesse campo.

A última informação que as fontes consultadas oferecem a respeito da LDBEN é de agosto de 1962. A revista Educação e Ciências Sociais comunicou que o relatório brasileiro à Conferência sobre Educação e Desenvolvimento Econômico e Social na América Latina (Chile, março de 1962) informava a promulgação da Lei de Diretrizes e Bases da Educação Nacional em 20 de dezembro de 1961 e a instituição do Conselho Federal de Educação, responsável pela elaboração e execução do Plano Nacional de Educação.

\footnotetext{
${ }^{123}$ Florestan FERNANDES, Editorial, Educação e Ciências Sociais, n. 16, p. 03.

${ }^{124}$ Ibidem, p. 05.

${ }^{125}$ Ibidem, p. 05.
} 


\subsection{Comentários sobre o tema.}

Maria Clara Mariani, em um trabalho sobre o INEP e o CBPE, apresenta dois depoimentos que caracterizam bem as discussões referentes à tramitação da Lei de Diretrizes e Bases da Educação Nacional, que se intensificaram a partir de 1959, com o Substitutivo Lacerda.

Elza Rodrigues Martins foi funcionária do INEP, a partir de 1949, e Diretora do CBPE, de 1969 a 1975. Em seu depoimento, ela afirma:

"A época do substitutivo Lacerda foi uma época muito efervescente. Reuniram-se no INEP muitas pessoas, por exemplo, Paulo Duarte, da revista Anhembi, Geraldo Bastos Silva, que era um profundo conhecedor do ensino médio, Roque Spencer Maciel de Barros, Laerte Ramos de Carvalho, do Centro Regional de São Paulo, Joel Martins, Renato Jardim, Roberto Moreira, todos defendendo uma linha de participação e de verbas públicas para a instrução pública" $" 26$.

No depoimento de Darcy Ribeiro, Diretor da DEPS/CBPE, encontramos o seguinte comentário:

"A luta pela escola pública na batalha pela Lei de Diretrizes e Bases foi toda orientada por nós, do CBPE. (...)Uma das suas consequências foi atrair Florestan Fernandes, que era um cientista que escrevia sobre a organização social dos Tupinambás, para a tarefa da educação, foi um modo de chamá-lo para a realidade brasileira. Isso foi bom num momento em que se discutia a escola pública, em cuja defesa Florestan cresceu como líder. Dificilmente isso teria acontecido se não fosse Anísio, se não fosse o $C B P E^{, 127}$.

Comentando as características da década de 50, no que se refere à formação de cientistas sociais e educadores, Mariza Corrêa também faz referência às discussões a respeito da escola pública:

"A década de 50 foi também um momento rico na experiência docente (...): todo o debate a respeito da escola pública, além de muito atual, é bem um indicador disso. Foi em meio a essas lutas, debates e inovações (legislativas, burocráticas, institucionais), que se formou a geração que, um pouco mais adiante, faria pósgraduação e se 'esqueceria' desses anos conturbados que viveu como estudante" ${ }^{28}$.

Marcos Cezar de Freitas aponta a segunda metade da década de 50 como um momento de vigor intelectual promovido pelo CBPE. Para este autor, o Manifesto de 1959 foi emblemático:

"Boa parte do pensamento educacional brasileiro do século vinte esteve muito envolvido com a necessidade política de defender a escola pública. Isso conduziu

\footnotetext{
${ }^{126}$ Maria Clara MARIANI, Universidades e instituições científicas no Rio de Janeiro, p. 189.

${ }^{127}$ Ibidem, p. 190.

${ }^{128}$ Mariza CORRÊA, A revolução dos normalistas, Cadernos de Pesquisa, n. 66, p. 14.
} 
vários educadores, muito especialmente Anísio Teixeira, a elaborar sínteses históricas com o objetivo de refutar, recorrendo aos exemplos do passado, o predomínio da esfera privada sobre a esfera pública. (...) Por ocasião dos debates em torno da Lei de Diretrizes e Bases da Educação Nacional, as polêmicas em torno a Anísio Teixeira deixavam claro porque a questão do privatismo tornava-se uma questão também intelectual e de grande exigência investigativa e argumentativa" ${ }^{29}$.

Libânia Nacif Xavier, comentando as discussões a respeito processo de tramitação da LDBEN que ocorreram nos Centros de Pesquisas Educacionais, afirma:

"O CBPE tornou-se uma trincheira de luta pela formulação de uma legislação mais flexível e democrática para a educação nacional, congregando boa arte dos intelectuais atuantes na cidade do Rio de Janeiro e acionando a rede de Centros Regionais de Pesquisas para ampliar, onde fosse possível, a mobilização em tono da aprovação de um projeto de LDBEN que expressasse as convicções democráticas de organização do sistema educacional brasileiro" ${ }^{130}$.

Sobre o Manifesto Mais uma vez convocados, a autora lembra que "ao mesmo tempo em que retomava os princípios educacionais explicitados desde os anos 30, marcava também a adesão de um outro grupo, formado pelos professores das áreas de história e filosofia da USP"131.

Marcus Vinicius da Cunha também destaca a importância do Manifesto de 1959:

"Retomando os princípios expressos pelos pioneiros da educação nova no Manifesto de 32, o documento tem o objetivo de influenciar as discussões que se dão, nos meios políticos, em torno da Lei de Diretrizes e Bases da Educação Nacional. (...) No contexto da luta em defesa do ensino público, os signatários do manifesto de 1959 levam em consideração a necessidade de a escola se ajustar à realidade social $e$ política do mundo em mudança. Trata-se de um raciocínio que determina a necessidade da adequação dos procedimentos pedagógicos à ordem social. Esse ponto de vista implica a adoção de instrumentos capazes de verificar objetivamente a realidade social e, deste modo, auxiliar o planejamento das mudanças" ${ }^{132}$.

\section{Considerações Gerais.}

Os temas selecionados pretendem sintetizar as principais preocupações intelectuais das pessoas que estiveram vinculadas ao Centro Regional de Pesquisas Educacionais de São Paulo, no período de 1956 a 1961. Eles foram selecionados em função da frequência com que apareciam nas publicações consultadas e pela contribuição que poderiam dar ao acréscimo de

\footnotetext{
${ }^{129}$ Marcos Cesar de FREITAS, Da idéia de regional no projeto do Centro Regional de Pesquisas Educacionais de São Paulo, p. 08-9.

${ }^{130}$ Libânia Nacif XAVIER, O Brasil como laboratório: educação e ciências sociais no projeto dos Centro Brasileiro de Pesquisas Educacionais, p. 220.

${ }^{131}$ Ibidem, p. 228.

${ }^{132}$ Marcus Vinicius da CUNHA, Indivíduo e Sociedade no ideário escolanovista (Brasil: 1930-1960), p. 153-4.
} 
informações relevantes para a melhor compreensão dos motivos que justificaram a criação, escolha de objetivos e planos de trabalho do Centro paulista.

A inclusão de intelectuais vinculados ao CBPE justifica-se, algumas vezes, por complementar e tornar mais claras algumas formulações contidas nas publicações do CRPE/SP. Outras vezes, somente a revista do CBPE continha informações julgadas relevantes para a compreensão das discussões que aconteciam no Centro Regional paulista como, por exemplo, os problemas enfrentados na tramitação da Lei de Diretrizes e Bases da Educação Nacional no Congresso.

A tramitação da LDBEN no Congresso Nacional foi um tema bastante discutido pelos pesquisadores do CBPE e do CRPE/SP. Cabe lembrar que o Manifesto "Mais uma Vez Convocados", de 1959, foi redigido por Fernando de Azevedo, Diretor do Centro paulista. Foram citados neste capítulo diversos artigos e discursos que trataram do tema ao longo do período de 1952 até 1962 e que constavam nas fontes pesquisadas, diretamente relacionadas aos Centros de Pesquisas. Um dos pontos mais comentados neste debate foi a crítica à proposta de que o Estado subsidiasse as escolas privadas. Os educadores não defendiam o tão comentado "monopólio estatal da educação", mas acreditavam que eram princípios democráticos a inversão de verbas públicas apenas para escolas públicas, e a fiscalização estatal de todas as escolas.

Alguns dos comentários encontrados a respeito deste tema destacam a participação de intelectuais paulistas, sobretudo aqueles vinculados à Faculdade de Filosofia da USP, no processo de discussão da LDBEN. O grupo liderado por Florestan Fernandes teve uma atuação importante em diversas frentes, contribuindo para o debate educacional através de conferências, palestras e atos públicos.

O tema Ciências Sociais e Educação servia de pressuposto à própria idéia de criação dos Centros de Pesquisas Educacionais. Anísio Teixeira, Florestan Fernandes e Fernando de Azevedo foram os intelectuais que mais contribuíram para a discussão desse tema no contexto das fontes pesquisadas neste trabalho. Dois pontos principais eram defendidos: a escola era uma instituição social e somente poderia ter seus problemas entendidos através da análise de sua inter-relação com o meio social em que ela se inseria; e, os problemas educacionais do Brasil, em geral, e do Estado de São Paulo, em particular, somente poderiam ser tratados objetivamente através de pesquisas científicas resultantes da colaboração entre educadores e cientistas sociais que, utilizando-se dos recursos próprios de suas formações colaborariam 
mutuamente para a elaboração de uma nova política educacional, no âmbito regional ou nacional.

A inclusão do trabalho de Luiz Pereira, a respeito da "sociologização" do pensamento pedagógico, e dos comentários de outros autores que enfatizam a importância da pesquisa sociológica promovida pelo Centro, serve para dar destaque a um ponto de vista apontado como predominante nas entrevistas realizadas com pesquisadores que atuaram no Centro, na época. A adoção deste ponto de vista teria gerado duas consequências: de um lado, atraiu cientistas sociais para a análise de problemas educacionais mas, por outro lado, criou divergências entre pedagogos e sociólogos dentro do Centro, o que teria dificultado a realização de pesquisas conjuntas.

A questão da Pesquisa Científica e Planejamento Educacional estava diretamente relacionada à necessidade de elaboração de uma nova política educacional. Renato Jardim Moreira foi o intelectual de maior destaque na defesa da necessidade de elaboração de levantamentos que servissem de base à planificação da educação em São Paulo. Para ele, a investigação social deveria estar comprometida com o planejamento da ação política, para atingir seus objetivos práticos. $\mathrm{O}$ instrumento indicado para obtenção dos dados necessários seria o levantamento que, num contexto de um programa de pesquisas integradas, atenderia à administração escolar e às necessidades das pesquisas científicas.

Os comentários a respeito da questão do planejamento enfatizam a crença, que existia na época, a respeito da racionalidade que seria proporcionada pela planificação educacional. $\mathrm{O}$ planejamento era entendido como resultado da pesquisa científica aplicada ao estudo das questões educacionais. Nota-se nos planos de trabalho sugeridos na criação dos Centros a preocupação com o desenvolvimento de um conhecimento científico a respeito dos problemas educacionais. A origem dessa preocupação de Anísio Teixeira pode ser identificada no seu contato com as idéias de William James, Peirce e John Dewey. Por outro lado, as entrevistas realizadas com intelectuais que participaram das atividades do CRPE/SP apontam para a grande influência exercida pelas idéias de Mannheim a respeito de planificação.

O Desenvolvimento econômico, mudança cultural e educação era outro tema que dava base às formulações teóricas e práticas dos intelectuais vinculados aos Centros. Diversos autores apontavam que o sistema educacional não atendia às necessidades do desenvolvimento econômico e social brasileiro, gerando problemas, tanto na esfera do desenvolvimento de nossa capacidade produtiva quanto no que se refere à sua capacidade de atuação enquanto fator racional de mudança. 
As discussões a respeito do papel da educação como fator de mudança social surgem nos trabalhos de intelectuais como Fernando de Azevedo, Florestan Fernandes, Luiz Pereira, Fernando Henrique Cardoso e Octávio Ianni que, especialmente nos trabalhos apresentados no Simpósio sobre Problemas Educacionais Brasileiros, deixaram mais claros seus pontos de vista a respeito desse assunto. Há um consenso de que a educação, por si só, não tem o poder de mudar a sociedade. A educação institucionalizada tem um papel caracteristicamente conservador. Entretanto, a escola está inserida em um contexto social que, na época, especialmente em São Paulo, correspondia a diversas mudanças, no sentido da urbanização e da industrialização. Caberia ao educador elaborar um tipo de educação que servisse ao processo global de transformação de toda a estrutura sócio-econômica, obviamente, em um contexto democrático.

Os problemas educacionais brasileiros são vistos como sendo não estritamente pedagógicos, mas sobretudo sociais. Portanto, como a solução para esses problemas não depende apenas de reformas escolares, os educadores deveriam assumir suas responsabilidades e posições extrapedagógicas para com a sociedade.

Os comentários encontrados a respeito dessa temática enfatizam a o problema da "dualidade" existente no país - o Brasil moderno e o Brasil arcaico - que comprometia o desenvolvimento nacional. 


\section{Capítulo 7. O Centro Regional de Pesquisas Educacionais de São Paulo e a ideologia nacional desenvolvimentista.}

A segunda metade dos anos 50 corresponde aos anos do Governo Juscelino Kubitschek, auge da ideologia nacional-desenvolvimentista e período no qual várias instituições dedicadas às Ciências Sociais foram criadas ${ }^{1}$. Entre elas, interessa-nos destacar o Centro Brasileiro de Pesquisas Educacionais, por estar diretamente relacionado à criação do CRPE/SP; e, o Instituto Superior de Estudos Brasileiros (ISEB) que foi responsável elaboração teórica da "ideologia do desenvolvimento".

O CBPE e os Centros Regionais eram órgãos de pesquisa do Instituto Nacional de Pesquisas Educacionais (INEP), do Ministério da Educação. O ISEB, apesar de ser uma instituição isolada, também era subordinado ao Ministério da Educação do Governo Kubitschek. Quais as semelhanças e diferenças, em termos ideológicos, que podem ser identificadas entre o CRPE/SP e o ISEB?

Para tentar responder a essa pergunta, este capítulo compõe-se de três partes: na primeira, as principais características da ideologia desenvolvimentista e da política educacional do Governo Kubitschek são identificadas; na segunda, procura-se caracterizar a ideologia nacional-desenvolvimentista do ISEB e as divergências existentes entre os intelectuais paulistas e os isebianos; e, na terceira, são apresentadas algumas sugestões a respeito das semelhanças e diferenças entre a ideologia isebiana e os propósitos do CRPE/SP.

\section{A ideologia desenvolvimentista do governo Juscelino Kubitschek.}

Ao estudar o desenvolvimentismo característico do governo Juscelino Kubitschek, Miriam L. Cardoso apresenta-o da seguinte forma:

“(...) ele teria que ser visto como parte de uma ideologia mais ampla - a ideologia do desenvolvimento, que acompanha o processo de uma sistema global específico - o sistema capitalista, num tipo particular de região - as regiões subdesenvolvidas em fase de crescimento, num momento particular de crescimento - quando o desenvolvimento espontâneo já não mais parece possível"2.

A conjuntura econômica de meados nos anos 50 havia mudado em relação àquela vigente no início da década. Estudos realizados pelo BNDE (em relação ao Brasil) e pela

\footnotetext{
${ }^{1}$ Maria Hermínia Tavares de ALMEIDA apresenta sete instituições dedicadas às Ciências Sociais criadas no Rio de Janeiro, de 1950 a 1954, no trabalho "Dilemas da institucionalização das ciências sociais no Rio de Janeiro", publicado no livro História das ciências sociais no Brasil, vol. 1, p. 188-216.

${ }_{2}^{2}$ Miriam Limoeiro CARDOSO, Ideologia do Desenvolvimento no Brasil, p. $78 .$.
} 
CEPAL (em relação à América Latina), referentes ao período de 1953 a 1955, indicavam que o desenvolvimento espontâneo, característico dos anos de 1950 a 1954, não teria condições de continuar se processando, uma vez que ocorreram alterações em aspectos econômicos fundamentais $^{3}:$ 1. As circunstâncias de origem externa que proporcionaram esse desenvolvimento haviam se alterado; 2. As relações de intercâmbio com os países desenvolvidos haviam se deteriorado; e, 3. A poupança existente no Brasil e nos demais países da América Latina não era suficiente para a manutenção do ritmo de crescimento econômico.

O Grupo Misto BNDE-CEPAL, por seu reconhecido caráter técnico, influenciou a programação governamental do período, sugerindo soluções e estratégias alternativas para equacionar o problema do desenvolvimento. A necessidade de execução de um planejamento econômico era sugerida como instrumento eficaz para a solução do problema de desenvolvimento que o país enfrentava.

De modo geral, as análises técnicas sugeriam a necessidade de associação com o capital externo para que fosse possível a continuidade do processo de desenvolvimento brasileiro. Essa sugestão seria adotada por Juscelino Kubitschek a partir de sua posse, em 1956.

\subsection{Ideologia desenvolvimentista: ordem social e crescimento econômico.}

Para Juscelino Kubitschek o desenvolvimento significava crescimento econômico realizado através da industrialização da produção brasileira. Somente o desenvolvimento econômico superaria o atraso do Brasil em relação aos países do primeiro mundo. No seu entender, a industrialização proporcionaria o aumento da riqueza nacional e, consequentemente, a prosperidade de toda a população.

Entretando, o fim da miséria gerado por esse desenvolvimento econômico não era a principal finalidade da ideologia desenvolvimentista. Conforme Miriam L. Cardoso ${ }^{4}$, a sua finalidade última era a manutenção da democracia, ou seja, a manutenção da ordem através da segurança do sistema político, econômico e social vigente.

A pobreza (sinônimo de subdesenvolvimento) era vista como um perigo à democracia, uma vez que instigava a revolta e a subversão entre a população desfavorecida. A luta contra a miséria e contra a subversão significava uma luta em defesa da democracia e seus ideais de

\footnotetext{
${ }^{3}$ Ibidem, p. 384-403.

${ }^{4}$ Ibidem, p. 229.
} 
liberdade e igualdade de oportunidades à todos os membros da sociedade, indistintamente. Essa idéia de ordem como base de sustentação democrática era um elemento fundamental para o estabelecimento da transformação econômica pretendida, uma vez que controlava o sentimento de insatisfação das classes desfavorecidas ao acenar com a possibilidade de ascensão social através do trabalho.

A origem da pobreza é identificada no tradicionalismo característico da nossa sociedade, baseada na exportação de produtos primários, que não permitia a expansão econômica. O desenvolvimentismo viria para modernizar esse modelo econômico, introduzindo a valorização da agricultura para o mercado interno e, sobretudo, a industrialização.

Conforme Míriam L. Cardoso, “os aspectos centrais da ideologia do desenvolvimento tal como a concebe JK são, como vemos, a prosperidade e a ordem. Os dois se fundem com seu conceito de soberania como equivalente da autodeterminação, identificada como igualdade com os grandes Estados", A soberania somente seria possível aos países que tivessem se afirmado no terreno econômico e onde houvesse democracia.

Nesse contexto, a cooperação do capital internacional no processo de desenvolvimento econômico era entendida como necessária e positiva, não representando problemas à soberania nacional. No discurso desenvolvimentista, o destino do Brasil era ser um país próspero, uma vez que a Nação era potencialmente rica em recursos naturais e humanos. O capital internacional somente colaboraria para que atingíssemos nossa "velocidade de arranque" no desenvolvimento econômico. Portanto, nessa concepção, “a cooperação internacional que ajuda a promover o desenvolvimento não interfere na soberania do país ao qual se dirige, mas, ao contrário, contribui positivamente para que ele a alcance" 6 .

Através da perspectiva desenvolvimentista, a soberania nacional e o sucesso político e social brasileiro seriam consequências do sucesso econômico que o País alcançaria através de um planejamento adequado de seu processo de desenvolvimento. A decisão política de incluir no discurso desenvolvimentista a questão da soberania nacional agradava tanto aos nacionalistas de direita, quanto aos de esquerda, contribuindo para conter as inquietações políticas características do período correspondente à posse de Kubitschek na presidência, em 1956.

\footnotetext{
${ }^{5}$ Ibidem, p. 98.

${ }^{6}$ Ibidem, p. 98.
} 
O Programa de Metas do governo Kubitschek visava uma "enorme e evidente aceleração do processo de crescimento" "7, baseado no incremento das condições de investimento. Miriam L. Cardoso aponta que uma preocupação marcante na apresentação deste Programa era mostrar a viabilidade do projeto, apresentando-o como realizável e não exagerado. As pretensões governamentais justificavam-se através da defesa da idéia de racionalidade econômica, na qual dava-se prioridade aos investimentos e restringiam-se as despesas; também havia uma política de incentivo às exportações, com defesa de preços; outro ponto era a defesa da necessidade de restrição do consumo, associado à inflação; o último e fundamental item desse plano era a necessidade de atração de capital estrangeiro, através das exportações, empréstimos ou de investimentos diretos.

"O Programa de metas foi montado contando com uma participação estrangeira da ordem de 1/3 dos seus investimentos globais" ${ }^{\text {" }}$. Essa afirmação de Míriam L. Cardoso dá uma noção da importância da necessidade de atração de capital público e privado externo para a viabilização do programa governamental. A ideologia desenvolvimentista criou diversas justificativas para que a opinião pública nacional entendesse como positivo o financiamento estrangeiro do desenvolvimento de setores importantes da economia do país e para que os órgãos de financiamento e investimentos do exterior se interessassem pelo Brasil.

Defendia-se a idéia de que a América Latina ocupava uma posição estratégica na defesa da democracia ocidental. No contexto da Guerra Fria, os países desenvolvidos e subdesenvolvidos se relacionariam tendo em vista esse objetivo comum de combate ao comunismo. Por um lado, os países subdesenvolvidos garantiriam a fidelidade aos ideais democráticos (entenda-se capitalismo) na medida em que os países desenvolvidos cooperassem com o capital necessário ao seu crescimento econômico e consequente enriquecimento nacional. Por outro lado, os países desenvolvidos colaborariam tendo em vista a manutenção do sistema em que são dominantes.

Com o objetivo de estabelecer essa cooperação mútua, o Brasil propôs a realização da "Operação Pan-americana", um programa de desenvolvimento econômico que envolvia os Estados Unidos e toda a América Latina. Esse Programa previa a realização de "acordos de preços de produtos primários e empréstimos públicos a longo prazo"9. Entretanto, esses princípios são colocados em prática apenas quando os Estados Unidos rompem as relações

\footnotetext{
${ }^{7}$ Ibidem, p. 187.

${ }^{8}$ Ibidem, p. 187.

${ }^{9}$ Thomas E. SKIDMORE, Brasil, de Getúlio Vargas a Castelo Branco (1930-1964), p. 215.
} 
com Cuba e propõem a "Aliança para o Progresso". O Programa da "Aliança para o Progresso" dava ênfase à manutenção das garantias políticas, consideradas “indispensáveis à manutenção e expansão do poderio econômico ocidental"10.

De acordo com a análise dos programas da "Operação Pan-americana" e da "Aliança para o Progresso", Míriam L. Cardoso observa que, para a ideologia desenvolvimentista, as nações subdesenvolvidas eram estratégicas na definição ideológica do mundo, mas para os países desenvolvidos, a questão do desenvolvimento econômico daqueles países não era prioritária, desde que as forças sociais locais pudessem manter a subversão sob controle. Com isso, o Brasil continuava a enfrentar dificuldades em captar recursos estrangeiros para sustentar seu desenvolvimento.

A ideologia desenvolvimentista procurava sustentar a idéia de que a cooperação dos países desenvolvidos não era questão de generosidade, mas de razão, uma vez que o Brasil acenava com a possibilidade de grande rentabilidade ao capital aqui aplicado, ao mesmo tempo em que esse capital contribuiria para o controle da subversão, para manutenção da ordem e para a manutenção da defesa de todo o continente contra os avanços do socialismo.

Por outro lado, além da necessidade de capital, o crescimento econômico também dependia da aquisição de técnica avançada, que "possa ser incorporada ao processo de desenvolvimento, tornando-o mais produtivo e mais eficiente, portanto mais rápido e menos oneroso" ${ }^{11}$. Esses recursos técnicos chegaram ao Brasil sob a forma de assistência técnica fornecida por organismos internacionais como a ONU, a OEA e o Ponto IV e, sobretudo, sob a forma de importação de novos equipamentos. Com a finalidade de encorajar as empresas estrangeiras a trazerem equipamentos industriais para o Brasil, "o governo fez uso liberal da Instrução 113 da SUMOC [Superintendência da Moeda e do Crédito], baixada durante o Governo Café Filho"12 (1955), que isentava as empresas estrangeiras "da necessidade de providenciar cobertura cambial externa para importar maquinaria, desde que estivessem associadas a empresas brasileiras - vantagem não gozada por firmas inteiramente nacionais" "13. Essa regulamentação também liberalizava a entrada e saída de capitais externos no País, o que efetivamente serviu de incentivo para que se realizassem investimentos estrangeiros, sobretudo em indústrias-chave, como a de produção de veículos.

\footnotetext{
${ }^{10}$ Míriam Limoeiro CARDOSO, Ideologia do Desenvolvimento no Brasil, p. 133.

${ }^{11}$ Ibidem, p. 191.

${ }^{12}$ Thomas E. SKIDMORE, Brasil, de Getúlio Vargas a Castelo Branco (1930-1964), p. 206.

${ }^{13}$ Ibidem, p. 206.
} 
Em relação à política econômica interna, o Governo JK buscava conseguir uma colaboração entre a iniciativa pública e privada. O Estado propunha-se a atuar para estimular as primeiras etapas do processo de desenvolvimento econômico, substituindo a iniciativa privada em setores em que ela não atuaria por não ter seus interesses econômicos atendidos e incentivando-a onde esse interesse existisse.

O Estado também se responsabilizava por promover a produtividade, seja através do aperfeiçoamento tecnológico - utilizando-se do sistema educacional e dos centros de pesquisas existentes - seja através da "ideologia como instrumento de mobilização"14 divulgando a crença em um futuro melhor para o trabalhador que viria com o desenvolvimento.

O planejamento era outra forma de estímulo aos investimentos, uma vez que, fundamentalmente, "se volta para a eficiência, com a atenuação dos pontos de estrangulamento - que tendem a diminuí-la, com a adoção de outras medidas que aumentam a produtividade do capital e do trabalho" ${ }^{\prime 15}$. Evaldo Vieira aponta que Kubitschek, mesmo antes de sua eleição, proclamava a planificação como assunto de sua preferência nos pronunciamentos ${ }^{16}$. Segundo esse autor, a "apologia da planificação" esteve presente em todo o período Kubitschek, sendo que o Presidente "louvava o fato de, pela primeira vez, haver um plano nacional em execução no Brasil"17.

A perspectiva desenvolvimentista, é interpretada por Míriam Cardoso como sendo transformadora e conservadora ao mesmo tempo: "mudar, dentro da ordem, para garantir a ordem" seria o slogan de sua política geral:

"A atitude desenvolvimentista é francamente transformadora, ela mostra um profundo inconformismo com o presente. Por outro lado, ela é abertamente conservadora, preocupada que está com a garantia da ordem, acima de tudo. Quanto ao campo econômico ela é marcadamente inovadora, impulsionando os setores emergentes, concentrando os investimentos em áreas novas, predominantemente industriais - mesmo que com isso esteja contrariando a hegemonia que vigorava anteriormente. Atua, pois, no sentido de propiciar o surgimento ou o fortalecimento de uma nova hegemonia. Essas transformações no âmbito da hegemonia, no entanto, se processam todas nos limites das classes dominantes. (...) O seu inconformismo com o presente só vai até aí: primeiro, ele se refere unicamente aos aspectos econômicos; segundo, ele só admite o confronto intra-classe dominante. São essas restrições, é essa fixação de limites ao seu caráter inovador que lhe assinalam sua outra característica, o conservadorismo. (...)Isto é, a atitude política do desenvolvimentismo

\footnotetext{
${ }^{14}$ Míriam Limoeiro CARDOSO, Ideologia do Desenvolvimento no Brasil, p. 207.

${ }^{15}$ Ibidem, p. 208.

${ }^{16}$ Evaldo VIEIRA, Estado e miséria social no Brasil, p. 84.

${ }^{17}$ Ibidem, p. 84.
} 
é conservadora na medida em que dá maior solidez aos processos hegemônicos mais importantes, aqueles que se exercem dos grupos globalmente dominantes para os dominados. Fazendo com que estes aceitem o projeto daqueles como o seu próprio, não só mantém, como estende o poder de direção e de domínio"18.

\subsection{A política educacional e sua adequação ao desenvolvimento econômico.}

Com a ênfase dada pela ideologia desenvolvimentista à racionalização do processo de crescimento econômico, havia a necessidade de adequação do sistema educacional existente às exigências desse desenvolvimento. A perspectiva geral assumida estabelece uma interdependência entre educação e desenvolvimento: o sistema educacional deveria ser ampliado para atender às novas demandas do sistema produtivo.

Juscelino Kubitschek, citado por Miriam L. Cardoso, relaciona educação e desenvolvimento na seguinte afirmação:

"Em nossos dias, a educação, a ciência e as atividades produtoras constituem três faces de um mesmo problema, que só em conjunto pode ser resolvido. Por assim entender é que o Governo vem dando passos decisivos a fim de que, simultaneamente com a industrialização do País, se acelere o seu desenvolvimento cultural $e$ científico" $"$.

As transformações educacionais nos diversos níveis do ensino deveriam acompanhar as transformações empreendidas na indústria, atendendo às suas necessidades, sobretudo no que se refere à formação de pessoal. A escola deveria "preparar cada um, de acordo com o seu talento, para ser capaz de desempenhar as tarefas que lhe incumbem no desenvolvimento" 20 .

A educação, de modo geral, deveria fazer com que o trabalhador atingisse a produtividade requerida pela sociedade industrial. Somente os mais aptos seriam selecionados para dar continuidade aos seus estudos e contribuir para desenvolver nossa cultura. Portanto, o papel da escola no contexto desenvolvimentista seria o de formar recursos humanos com conhecimento técnico, ministrando um ensino de caráter eminentemente prático ${ }^{21}$.

Conforme Evaldo Vieira, Kubitschek indicava como sendo "os dois princípios norteadores da ação transformadora do seu governo: a descentralização administrativa e a

\footnotetext{
${ }^{18}$ Míriam Limoeiro CARDOSO, Ideologia do Desenvolvimento no Brasil, p. 228.

${ }^{19}$ Juscelino KUBITSCHEK, Mensagem Presidencial de 1958 apud Miriam Limoeiro CARDOSO, Ideologia do Desenvolvimento no Brasil, p. 220.

${ }^{20}$ Míriam Limoeiro CARDOSO, Ideologia do Desenvolvimento no Brasil, p. 220.

${ }^{21}$ Note-se que, em 1959, Paulo Freire publicou seu primeiro livro, Educação e atualidade brasileira, no qual defende a democratização fundamental da sociedade e a formação da personalidade democrática através da educação, elementos que o distinguiam dos autores isebianos. A esse respeito ver: Celso BEISIEGEL, Política e Educação Popular, p. 18-93.
} 
flexibilidade dos currículos"22. A "educação para o trabalho" passou a ser a referência para a formação escolar.

Nesse contexto, a criação de cursos complementares ao ensino primário foi proposta. Esses cursos forneceriam uma orientação profissional àquela parcela da população - sua maioria - que somente frequentava o curso primário. Em 1958, Kubitschek destacava a construção de 10 mil prédios, através do Fundo Nacional do Ensino Primário e "importava-se, ainda, com a ampliação da escolaridade para 6 anos, com a melhoria da formação dos professores de nível primário e com o aperfeiçoamento deles"23.

Outro objetivo governamental era a erradicação do analfabetismo, que atingia $50 \%$ da população e representava um entrave para o desenvolvimento. Comentando a política de alfabetização do governo, Celso Beisiegel afirma:

"Durante os primeiros anos do Governo Kubitschek a educação de adultos recebeu pouca atenção. Um outro empreendimento de maior vulto somente seria inaugurado em 1958 quanto, nos termos da Portaria n. ${ }^{o}$ 5-A, de 9 de janeiro, o Ministério da Educação e Cultura instituiu a Campanha Nacional de Erradicação do Analfabetismo. Numa primeira etapa, dedicada à execução de um 'plano-piloto' experimental, a Campanha previa trabalhos de expansão e melhoria do ensino primário fundamental comum, ao mesmo tempo em que cuidava da educação elementar e da iniciação profissional de adolescentes e adultos, em um município de cada uma das regiões Norte, Nordeste, Leste, Centro-oeste e Sul do país. Embora, inicialmente o 'plano-piloto' nada houvesse previsto para o Estado de São Paulo, um pouco mais tarde a Campanha absorveria uma iniciativa do Rotary Club de São José dos Campos, com vistas à organização do ensino industrial no município de Caraguatatuba"24.

Em 1959, o discurso presidencial referia-se à “alfabetização de 8.900 alunos acima de 15 anos de idade, ao preparo de 425 professores especializados e à formação de 350 professores para atuar na zona rural” ${ }^{, 25}$. Em 1960, destacava-se a instalação de 300 rádioescolas que auxiliariam na alfabetização de moradores do interior ${ }^{26}$.

Os cursos médios existentes eram bastante criticados por manterem uma orientação fundamentalmente acadêmica e por visarem a preparação de alunos para os cursos superiores. Incentivava-se a criação de cursos técnicos-profissionais em nível médio como forma de integração do homem à civilização industrial. Segundo Evaldo Vieira:

\footnotetext{
${ }^{22}$ Evaldo VIEIRA, Estado e miséria social no Brasil, p. 99.

${ }^{23}$ Ibidem, p. 101.

${ }^{24}$ Celso de Rui BEISIEGEL, Estado e Educação Popular, p. 157-8.

${ }^{25}$ Evaldo VIEIRA, Estado e miséria social no Brasil, p. 102.

${ }^{26}$ Ibidem, p. 102.
} 
“Em 1956, Kubitschek falava em instalar no País uma organização educacional com maior liberdade e com maiores possibilidades de expansão, principalmente a nível do ensino secundário. Além do mais, também reconhecia a premente necessidade de aprimorar professores, técnicos, administradores e inspetores daquele nível de ensino. (...) $O$ interesse pela educação profissionalizante transparecia no fato de, entre 1957 e 1959, os recursos financeiros do ensino industrial a nível médio terem-se multiplicado por 4, em virtude de decisão governamental ${ }^{\text {,27. }}$.

O ensino superior era tido como destinado aos mais aptos. As Universidades formariam cientistas e tecnólogos capazes de encontrar soluções para os problemas que o desenvolvimento colocava. Para tanto, planejava-se realizar a ampliação, aparelhamento e diversificação dos cursos superiores que se tornariam capazes de formar professores especializados e uma elite cultural qualificada. Evaldo Vieira destaca que o Presidente entendia ser necessário impedir a "expansão numérica dos institutos de ensino superior do tipo tradicional" ${ }^{28}$ (interessados em ciência pura), enfatizando a necessidade de criação de institutos destinados ao desenvolvimento da ciência aplicada. Durante o Governo JK criaramse alguns institutos na área da agricultura e da veterinária: Instituto de Economia Rural, da Universidade Rural; Instituto de Genética, da Escola Superior de Agricultura "Luiz de Queiroz" da Universidade de São Paulo; Instituto de Mecânica Agrícola, da Universidade do Paraná; Instituto de Tecnologia Rural, da Escola de Agronomia da Universidade do Ceará.

A transformação do sistema de ensino era entendida pela ideologia desenvolvimentista do Governo JK como fundamental para que o processo de desenvolvimento atingisse patamares mais elevados no futuro: "Agora, as anteriores reivindicações de melhoria e expansão do ensino seriam retomadas sob uma nova linguagem: a educação reivindicada para todos os brasileiros se apresentaria como 'condição', como 'requisito' ou mesmo como 'fator' do desenvolvimento nacional" 29 .

Apesar da existência de vários projetos e de medidas que efetivamente foram tomadas pelo Governo Juscelino Kubitschek, alguns autores qualificam a política educacional desse período como "insatisfatória" ou "pouco vigorosa" 30 em relação às necessidades da Educação da época. Destaca-se o fato de que das trinta metas prioritárias estipuladas pelo governo, somente em uma colocou-se a importância de uma política social de formação de pessoal técnico para atender à demanda industrial.

\footnotetext{
${ }^{27}$ Ibidem, p. 100-1.

${ }^{28}$ Ibidem, p. 100.

${ }^{29}$ Celso de Rui BEISIEGEL, Estado e Educação Popular, p. 78.

${ }^{30}$ Ver: Edgard Luiz de Barros, O Brasil de 1945 a 1964, p. 44; e, Evaldo Vieira, Estado e miséria social no Brasil, p. 103.
} 
Evaldo Vieira apresenta alguns índices nacionais da educação do período juscelinista: o percentual de alunos matriculados no primeiro ano do curso primário que chegavam a sua conclusão passou de 19\% (1955) para 23\% (1960); o número do alunos por professor no ensino primário passou de 35,3 (1955) para 33 (1960); no ensino médio, o número de alunos por professor passou de 11,7 (1955) para 12,4 (1960); no ensino superior, esse número passou de 5,8 (1955) para 4,2 (1960); o percentual de professores sem o curso normal passou de 48\% (1955) para 46\% (1960); as matrículas no ensino primário aumentaram em 29\% (de 1955 a 1960); o número de unidades escolares aumentou em 20,1\% (de 1955 a 1958); as matrículas no ensino médio aumentaram em 58\% (de 1955 a 1960); as matrículas no ensino superior aumentaram em 30,1\% (de 1955 a 1960).

Os gastos federais com educação e pesquisa aumentaram de 5,96\% das despesas da União, em 1955, para 6,10\% em $1960^{31}$. Apesar de ter havido um aumento dos gastos federais com a educação e a pesquisa, as restrições orçamentárias impostas pelo governo federal sobre todo o orçamento - a partir de 1959 - restringiram o desenvolvimento de projetos educacionais e afetaram o financiamento de órgãos como o INEP, o CBPE e os Centros Regionais que tiveram suas capacidades de atuação e concretização de projetos educacionais $\operatorname{limitadas}^{32}$.

Em relação ao financiamento da educação no Brasil, o Governo Kubitschek não definiu uma linha única de ação, ele reivindicava o investimento de capital particular na Educação ao mesmo tempo em que destinava auxílios federais à escola privada e investia na expansão da escola pública ${ }^{33}$. Em meio a tudo isso havia a tramitação da Lei de Diretrizes e Bases da Educação Nacional no Congresso (que somente seria aprovada em dezembro de 1961) e a Campanha em Defesa da Escola Pública, que desencadeou debates entre os defensores da escola pública, universal e gratuita e os defensores de interesses privatistas.

\section{O ISEB e a ideologia nacional-desenvolvimentista.}

O ISEB (Instituto Superior de Estudo Brasileiros) foi criado através do Decreto n. ${ }^{o}$ 57.608 , de 14 de julho de 1955, com o objetivo de incentivar e promover o desenvolvimento nacional.

\footnotetext{
${ }^{31}$ Evaldo VIEIRA, Estado e miséria social no Brasil, p. 104.

${ }^{32}$ Conforme Skidmore: "Em janeiro de 1959, o presidente anunciou que o orçamento federal seria reduzido aos itens essenciais" (Thomas E. SKIDMORE, Brasil, de Getúlio Vargas a Castelo Branco, p. 220).

${ }^{33}$ Evaldo VIEIRA, Estado e miséria social no Brasil, p. 102.
} 
O Regulamento Geral da instituição informa que o ISEB era subordinado ao Ministério da Educação e Cultura, entretanto, ele contava com autonomia administrativa e "plena liberdade de pesquisa, de opinião e de cátedra".

O primeiro diretor executivo do ISEB foi Roland Corbisier e o Conselho Curador era composto por: Anísio Teixeira, Ernesto Luiz de Oliveira Júnior, Hélio Burgos Cabral, Hélio Jaguaribe, José Augusto de Macedo Soares, Nelson Werneck Sodré, Roberto de Oliveira Campos e Roland Corbisier.

Os responsáveis pelos departamentos eram: Álvaro Vieira Pinto (Filosofia), Cândido Mendes (História), Alberto Guerreiro Ramos (Sociologia), Hélio Jaguaribe (Ciência Política) e Evaldo Correa Lima (Economia).

Em relação às atividades desenvolvidas no ISEB, Caio Navarro de Toledo destaca o seguinte:

"Durante seus quase nove anos de existência, o ISEB promoveu cursos, conferências, seminários de estudos, pesquisas etc., dos quais participaram representantes das Forças Armadas, do Conselho de Segurança Nacional, do Congresso Nacional, dos ministérios de Estado; igualmente frequentaram tais realizações empresários industriais, líderes sindicais, parlamentares estaduais, professores e estudantes universitários, profissionais liberais, funcionários públicos etc. Muitos dos alunos dos cursos regulares (com duração de um ano escolar) recebiam bolsas de estudos de suas respectivas entidades ou repartições, dedicando, assim, turno integral às suas atividades junto ao ISEB,34.

O período em que a ideologia nacional-desenvolvimentista é considerada hegemônica dentro do ISEB corresponde aos anos do governo Kubitschek (1956 a 1961). Caio Navarro de Toledo afirma que, no final desse período, as objeções ao desenvolvimentismo do governo JK começam a surgir dentro da instituição. Entretanto, como o ISEB dependia de verbas governamentais para a sua manutenção, essas críticas não eram radicais.

Em 1958, Hélio Jaguaribe se desligou do ISEB alguns meses depois da publicação de seu livro $O$ nacionalismo na atualidade brasileira. Nele, Jaguaribe defendia teses consideradas "espúrias" pelo movimento nacionalista, como a privatização de setores básicos da economia (ex.: petroquímico). Guerreiro Ramos também saiu da instituição em 1958, criticando o apoio do ISEB à candidatura do marechal Lott à presidência da República. Nesse mesmo ano, os estatutos do ISEB foram modificados, ampliando os poderes do Diretor (ainda Roland Corbisier) e substituindo o Conselho existente. Depois dessas modificações Roberto

\footnotetext{
${ }^{34}$ Caio Navarro de TOLEDO, ISEB: fábrica de ideologias, p. 205.
} 
Campos, Hélio Burgos Cabral, Ewaldo Correia Lima e Anísio Teixeira também se desligaram da instituição.

Com o fim do Governo Kubitschek, a orientação teórica e política do ISEB passou por uma crescente "esquerdização". Conforme Caio N. Toledo, o apoio negado ao governo Jânio Quadros foi oferecido ao presidente Goulart que acenava com a possibilidade de realização de reformas nas estruturas básicas da sociedade.

Em 13 de abril de 1964, o ISEB foi extinto, através do Decreto n. ${ }^{\circ} 53.884$ (assinado por Paschoal Ranieri Mazzili, que respondia provisoriamente pela presidência da República após a deposição do presidente João Goulart), por ser considerado uma instituição subversiva e um "desserviço à nação" 35.

\subsection{A ideologia do desenvolvimento.}

A questão do desenvolvimento nacional, com ênfase na industrialização, não surgiu com o ISEB, nem com o governo Kubitschek, ela já existia há algum tempo no interior da formação social brasileira, sendo uma das heranças que a República recebeu do Estado Novo. Segundo Celso Beisiegel:

“Os ideais de desenvolvimento nacionalista continuaram presentes na vida política da nação, mesmo quando a rearticulação do sistema capitalista internacional, após o encerramento dos conflitos na grande guerra, os fazia dificilmente praticáveis. (...) [Com o ISEB] o ideário nacionalista se afirmava a adquiria o status de doutrina oficial do Estado no exato momento em que o país novamente se abria à penetração dos grandes investimentos internacionais" 36 .

Entretanto, a expressão "ideologia do desenvolvimento" se tornaria o emblema do ISEB, "estando presente na quase totalidade de suas publicações e em todas as duas definições e ordem programática" 37 .

Para Caio N. de Toledo, as intenções governamentais no período JK eram fazer do ISEB um núcleo de apoio e sustentação à política econômica definida pelo Plano de Metas. Em discurso proferido na solenidade de encerramento do curso regular de 1956, o presidente Juscelino Kubitschek definiu a tarefa da instituição como sendo a de "formar uma mentalidade, um espírito, uma atmosfera de inteligência para o desenvolvimento", e afirmou:

\footnotetext{
${ }^{35}$ Caio Navarro de TOLEDO, ISEB: fábrica de ideologias, p. 41.

${ }^{36}$ Celso BEISIEGEL, Política e educação popular, p. 09.

${ }^{37}$ Caio Navarro de TOLEDO, ISEB: fábrica de ideologias, p. 41-2.
} 
"mais do que uma tribuna brilhante, o ISEB quer ser um laboratório de pesquisas da realidade brasileira, visando conhecê-la e dar direção feliz ao processo do seu desenvolvimento"38.

Duas razões são apresentadas por Caio Navarro de Toledo para justificar a promoção de uma ideologia por uma instituição criada pelo Estado. A primeira refere-se ao fato de que os estatutos do ISEB lhe conferiam uma autonomia que isentava o Estado de qualquer responsabilidade sobre suas posições políticas e ideológicas. A segunda razão estava relacionada à crença de que a ideologia do desenvolvimento nacional promovida pelo ISEB representava os interesses gerais da nação como um todo, estando acima de disputas políticas ou ideológicas.

\subsubsection{Algumas noções básicas da ideologia isebiana.}

Quase todos os intelectuais conhecidos como "isebianos históricos" - Alberto Guerreiro Ramos, Cândido Mendes, Hélio Jaguaribe, Roland Corbisier e Álvaro Vieira Pinto (excetua-se Nelson Werneck Sodré) - concordavam com a necessidade de elaboração de uma ideologia que contribuísse para o desenvolvimento nacional.

Essa ideologia seria fruto da consciência crítica que teria condições de surgir naqueles países subdesenvolvidos que conseguiram romper com a estrutura colonial ou com a estagnação do subdesenvolvimento. Entretanto, essas transformações nas estruturas básicas somente levariam a nação como um todo a um estágio superior de desenvolvimento se estivessem amparadas por uma ideologia do desenvolvimento, que lhe conferiria clareza e precisão de metas a serem alcançadas. Roland Corbisier afirma:

"Se é verdade, como já se disse, que não há movimento revolucionário sem teoria do movimento revolucionário, não haverá desenvolvimento sem a formulação prévia de uma ideologia do desenvolvimento nacional $" 39$.

Um elemento considerado pelos isebianos como fundamental para a formulação da ideologia do desenvolvimento é a autenticidade. Caio Navarro de Toledo afirma que as discussões a respeito da natureza dessa autenticidade geraram dois posicionamentos distintos dentro do ISEB: um defendido por Hélio Jaguaribe, Roland Corbisier, Cândido Mendes e Guerreiro Ramos; e, outro defendido por Álvaro Vieira Pinto.

Para o primeiro grupo, a autenticidade da ideologia do desenvolvimento surgia da fase ou estrutura faseológica que estava sendo vivida pela história brasileira. Para Hélio Jaguaribe,

\footnotetext{
${ }^{38}$ Juscelino KUBITSCHEK, Discursos, Rio de Janeiro, ISEB, 1957, p. 48 apud Caio N. TOLEDO, ISEB: fábrica de ideologias, p. 42-3.
} 
essa estrutura faseológica abria caminho para o desenvolvimento independente, uma vez que, a partir de 1930, "a linha de maior representatividade ideológica para todas as classes sociais corresponde também à linha de maior autenticidade histórica" 40 , ou seja, os interesses das classes dominantes (ideologia representativa) correspondem aos interesses da comunidade como um todo (ideologia autêntica). A burguesia industrial progressista teria conseguido conquistar as camadas populares, tendo em vista o desenvolvimento.

Álvaro Vieira Pinto, por outro lado, acreditava que a ideologia autêntica deveria ser extraída da consciência das massas, pois são elas que "impõem a exigência de desenvolver-se o país" consciência coletiva, e revela os seus anseios em um projeto que não é imposto, mesmo de bom grado, às massas, mas provém delas" ${ }^{42}$. Entretanto, Álvaro Vieira Pinto reconhece a necessidade de existência de quadros intelectuais capazes de ordenar e explicitar esse projeto de desenvolvimento.

Celso Beisiegel, analisando essas concepções, destaca o fato de que o desenvolvimento, apesar de entendido como uma imposição das massas, somente seria atingido através da "atuação privilegiada das classes dominantes, desde que estas classes se fizessem também dirigentes, autênticas, identificadas com as necessidades orgânicas de transformação da sociedade",43.

Da mesma forma, Caio Navarro de Toledo aponta para o fato de que apesar das diferenças apresentadas entre os autores isebianos, elas se atenuam "quando se tem em conta que ambos pensam o desenvolvimento nacional como convergindo para a definitiva consolidação do capitalismo nacional"44. Além disso, esses autores acreditavam que a ideologia do desenvolvimento nacional possuía uma hegemonia, ou seja, a existência de ideologias dominantes e dominadas em conflito não era considerada um problema. Os isebianos acreditavam que não havia contradição de interesses na sociedade, uma vez que o projeto de desenvolvimento correspondia ao projeto de toda a nação.

Outro elemento fundamental da ideologia do desenvolvimento é a sua concepção de classes sociais e antagonismo de classes. Segundo Caio Navarro de Toledo, os autores isebianos entendiam que a sociedade brasileira do pós-30 encontrava-se dividida entre setores

\footnotetext{
${ }^{39}$ Roland CORBISIER, Formação e Problema da Cultura Brasileira, p. 87.

${ }^{40}$ Hélio JAGUARIBE, Condições institucionais do desenvolvimento, p. 13.

${ }^{41}$ Álvaro Vieira PINTO, Ideologia e desenvolvimento nacional, p. 33.

${ }^{42}$ Ibidem, p. 34-35.

${ }^{43}$ Celso BEISIEGEL, Política e educação popular, p. 48.
} 
"dinâmicos e produtivos" e setores "estáticos e parasitários", sendo que cada um desses setores poderia abrigar parcelas das três classes fundamentais (burguesia, classe média e proletariado).

Essa contradição entre "estagnação" e "desenvolvimento" representava, para os isebianos, o principal antagonismo existente na formação social brasileira que somente seria superado com o desenvolvimento, em termos capitalistas.

Entretanto, os isebianos divergiam quanto à composição desses "setores" antagônicos existentes na sociedade brasileira. Caio Navarro de Toledo acredita que para Vieira Pinto, Roland Corbisier e Nelson Werneck Sodré o principal agente das forças de estagnação era o imperialismo. Assumindo essa postura, esse grupo é contrário à entrada de capital estrangeiro no país. Segundo Vieira Pinto:

"A proteção ao capital estrangeiro, que até há pouco apresentava uma política de certo modo útil, tornou-se, agora, orientação nefasta. Desde que se produziram no âmbito interno do país condições favoráveis à acumulação do capital autóctone, toda a política que proteja o derrame de capital alheio no incentivo ao nosso desenvolvimento assume sentido antinacional por estabelecer concorrência desnecessária, além de prejudicial, por ser esmagadora dos nossos esforços próprios ao introduzir interferências estranhas num campo de decisões que, se nacionalmente puro, criará projetos fecundos para a comunidade ${ }^{\text {45 }}$.

Assumindo uma posição diversa, Hélio Jaguaribe acreditava que as forças de estagnação eram formadas por setores improdutivos ou decadentes da burguesia, classe média e proletariado. No seu entender, o nacionalismo - ideologia racionalizadora do comportamento político-social - era basicamente "um meio para atingir um fim: e como tal deve ser exercido, mediante o emprego dos instrumentos mais adequados para a realização desse fim" ${ }^{\text {46 }}$. Nesse sentido, aceitava-se a entrada de capitais estrangeiros no país, sendo que não haveria a necessidade sequer da existência de um monopólio do petróleo, desde que ele fosse explorado de forma eficaz e se proporcionasse à economia nacional o seu pleno uso e controle.

\subsection{O ISEB e o governo Kubitschek.}

Segundo a interpretação de Caio Navarro de Toledo, no início das atividades do ISEB, interessava ao governo a sua utilização como "instrumento ideológico" para a propaganda do

\footnotetext{
${ }^{44}$ Caio Navarro de TOLEDO, ISEB: fábrica de ideologias, p. 54-5.

45 Álvaro Vieira PINTO, Consciência e realidade nacional, vol. 2, p. 333.

${ }^{46}$ Hélio JAGUARIBE, O nacionalismo na atualidade brasileira, p. 52.
} 
desenvolvimentismo. Entretanto, com o tempo, esse interesse foi diminuindo em função de divergências no entendimento do que seria o desenvolvimento nacional e quanto à questão da entrada do capital estrangeiro no país.

Para esse autor, os isebianos nunca realizaram uma análise crítica da política desenvolvimentista colocada em prática por Juscelino Kubitschek. Somente podem ser encontradas algumas manifestações de apoio ou crítica ao governo federal.

As manifestações de apoio partiam daqueles que viam no desenvolvimento do capitalismo "nacional e autônomo" brasileiro, promovido pelo Governo, uma convergência com as idéias isebianas. Entre estes, encontram-se Hélio Jaguaribe e Guerreiro Ramos. Para Hélio Jaguaribe: "O governo JK é um governo que suscitou a adesão das grandes massas rurais e urbanas e assumiu o poder sob a bandeira do desenvolvimento econômico e da transformação econômica e social do país" ${ }^{\text {47 }}$.

Álvaro Vieira Pinto foi a principal voz discordante. Para ele, o governo juscelinista apresentava uma baixa taxa de consciência nacionalista e caracterizava-se pelo "entreguismo", criticando sobretudo a entrada do capital estrangeiro para financiar o desenvolvimento do país. Caio Navarro de Toledo acredita que era impossível a esses isebianos perceber que o desenvolvimentismo, na vigência do capitalismo, "só poderia se realizar por meio de um crescente fortalecimento das relações de dependência entre as metrópoles e as periferias, no qual a internacionalização da economia era uma das suas expressões" ${ }^{\prime 4}$.

\subsection{Divergências entre os intelectuais paulistas e o ISEB.}

Para Caio Navarro de Toledo, a ideologia isebiana "pretende-se saber, mas saber engajado, comprometido com a situação que busca desvendar" ${ }^{\prime 4}$. As ciências sociais elaboravam dados considerados pelos isebianos como "inertes", "pedras neutras". A ideologia se utilizaria desses dados e lhes daria um segundo significado que o contexto estritamente científico não possuía. A ideologia desenvolvimentista produzida pelo ISEB pretendia ser dotada de uma capacidade emancipadora, visando a superação do subdesenvolvimento através de uma aliança entre as classes e de um desenvolvimento econômico planejado, através dos quais a "periferia" atingiria condição de "centro".

\footnotetext{
${ }^{47}$ Hélio JAGUARIBE, Condições institucionais do desenvolvimento, p. 32.

${ }^{48}$ Caio Navarro de TOLEDO, ISEB: fábrica de ideologias, p. 161.

${ }^{49}$ Ibidem, p. 63.
} 
Roland Corbisier faz uma crítica direta ao comportamento intelectual dos brasileiros cultos:

"Colonizado mentalmente, o intelectual brasileiro assim como utilizava, sem transformá-los, os produtos acabados da indústria estrangeira, assim também pensava, sem transformá-las, com as idéias prontas que lhe vinham de fora. (...) Perdido nos 'outros', sua cultura se reduzia à erudição, quer dizer, ao conhecimento livresco das culturas alheias. (...) Conhecia, por exemplo, toda a sociologia estrangeira, era capaz de escrever tratados e dar cursos sobre essa ciência, mas era incapaz de utilizá-la como instrumento que lhe permitisse fazer uma interpretação sociológica da vida, da realidade do próprio país. (...) Não se chegava jamais à aplicação prática das categorias e dos métodos da ciência, na interpretação e na solução dos nossos problemas. Não sabíamos que a ciência não é uma 'coisa', mas o processo pelo qual nos procuramos cientificar a respeito das coisas. (...) Liam para ler, para ter lido e poder conversar sobre livros. Não liam para ver melhor, como se come para sobreviver. Incultos e eruditos, expatriados e marginais, vivendo em país sem destino próprio, não foram inautênticos por malícia ou pecado de espírito, mas simplesmente porque se achavam 'em situação', imersos em um contexto histórico, em uma 'forma específica da existência humana' que se caracterizava pela dependência e pela alienação" $"$.

Alfredo Bosi, no prefácio ao livro de Carlos Guilherme Mota, afirma que a inteligência universitária de São Paulo não se empenhou no projeto nacional-populista porque guardava uma história de combate ao Estado Novo (desde dos movimentos de 1932 e 1934) e identificava o nacionalismo com ditadura de direita:

"No conjunto, o seu "desenvolvimentismo" vai ater-se ao plano educacional: as suas bandeiras serão o aperfeiçoamento do ensino superior (de que a USP era exemplo no país) e a defesa da escola pública. Assim, enquanto o nacionalismo teórico vazava-se nos textos do ISEB e nas revistas de tendência esquerdista, à Universidade (bloqueada a simpatia por qualquer projeto nacional-popular) restava a reafirmação dos princípios liberais que tinham como referência central a Escola",51.

As razões para essa aversão ao nacionalismo são explicadas por Alfredo Bosi como sendo de diversas ordens: 1. Sua "filiação" inicialmente oligárquica e depois de classe média com status de hierarquia docente; 2. Desconfiança em relação à todo nacionalismo; 3 . "Descentramento" em face do poder: com a ascensão de Adhemar de Barros, os intelectuais viam-se afastados da participação política direta, ao mesmo tempo em que o Estado de São Paulo assumia uma posição secundária no plano político nacional; e, 4. Sua "prática intelectual", que a afastou de qualquer prática popular: "a Universidade fez ciência social nos moldes franceses e americanos, correndo, às vezes conscientemente, o risco de ser positiva e

\footnotetext{
${ }^{50}$ Roland CORBISIER, Formação e Problema da Cultura Brasileira, p. 80-2.

${ }^{51}$ Alfredo BOSI, Prefácio, Ideologia da cultura brasileira, p. V.
} 
funcionalista, logo 'cientificamente' neutra; e de alhear-se, durante largos anos, ao processo de 'conscientização' que se promovia em outras áreas menos acadêmicas da inteligência brasileira" ${ }^{\natural 2}$. Ocupada em fazer um "reconhecimento da realidade empírica", a Universidade procurava elaborar um retrato objetivo do processo de aceleração do sistema capitalista no Brasil e no exterior - transição do tradicional para o moderno - não se envolvendo nos debates ideológicos e condenando a "pretensão isebiana de colocar-se na vanguarda do pensamento e da prática políticos" ${ }^{\mathrm{5}}$.

Em entrevista concedida à Lourenço Dantas Mota (em 1985), Fernando Henrique Cardoso exemplificou a perspectiva crítica que os jovens intelectuais paulistas adotavam em relação aos isebianos: "um homem como Álvaro Vieira Pinto horrorizava o José Arthur Giannotti, porque do ponto de vista estritamente acadêmico ele era o samba do crioulo doido" ${ }^{54}$. Em outra entrevista, de 1992, o mesmo Fernando Henrique Cardoso adotaria uma postura menos agressiva:

"Nós tínhamos muita dificuldade com a prática esquerdista populista da época. Havia o ISEB, no Rio de Janeiro, e a questão do nacionalismo, que sempre cria um pouco de populismo, não é? O Hélio Jaguaribe, o Cândido Mendes, o Guerreiro Ramos tinham uma visão de um nacionalismo ardoroso, com alguns livros interessantes como A redução sociológica. Eles eram, na verdade, pessoas que sabiam do mundo. Nós não sabíamos. Nós sabíamos das idéias. Nós não estávamos muito ligando para esse negócio se o Juscelino vai dar certo ou não vai..."

A produção universitária paulista era divulgada através de publicações como as revistas Anhembi, Revista Brasiliense, Revista Brasileira de Estudos Políticos, Revista de História, entre outras, onde intelectuais como Antonio Candido e Florestan Fernandes procuravam aproximar-se da realidade de forma diferente daquela encontrada pelos isebianos, mantendo-se à margem do nacional-desenvolvimentismo, mas estabelecendo compromissos com a sociedade, com a ciência e com a política. Carlos Guilherme Mota destaca como grande preocupação de Florestan Fernandes nos anos 50 e 60 a questão do papel do intelectual numa sociedade em mudança, questão que envolvia a análise de diversos assuntos: desde os novos padrões de trabalho científico, até a defesa da Escola Pública.

\footnotetext{
${ }^{52}$ Ibidem, p. VI.

${ }^{53}$ Daniel PÉCAUT, Os intelectuais e a política no Brasil, p. 120.

${ }^{54}$ Entrevista de Fernando Henrique Cardoso à Lourenço Dantas Mota (1985), citada por Maria Arminda do Nascimento ARRUDA, A modernidade possível: cientistas e ciências sociais em Minas Gerais, História das ciências sociais no Brasil, vol. 1, p. 281.

${ }^{55}$ Entrevista de Fernando Henrique Cardoso, concedida ao jornal Folha de S. Paulo, Caderno 6, 17 de maio de 1992, p. 06, citada por Maria Arminda do Nascimento ARRUDA, A sociologia no Brasil: Florestan Fernandes e a escola paulista, História das ciências sociais no Brasil, vol. 2, p. 205.
} 
O artigo intitulado Atitudes e Motivações Desfavoráveis ao Desenvolvimento ${ }^{56}$, de 1959, serve para exemplificar essa afirmação. Nele, Florestan Fernandes aponta três dificuldades observadas nos trabalhos sociológicos que pretendem investigar os fenômenos de mudança social. A primeira refere-se às lacunas existentes nas explicações encontradas. A segunda dificuldade seria a impossibilidade de utilização desses conhecimentos na prática, comprometendo quaisquer planos de reconstrução social. A terceira dificuldade envolve um caráter moral.

Ao destacar a magnitude moral das dificuldades encontradas nos estudos relacionados com o desenvolvimento social, Florestan Fernandes critica o fato de que eles incentivam mudanças subordinadas aos interesses e aos valores sociais das camadas dominantes na estrutura de poder:

“Medidas formuladas em nome dos 'interesses da Nação' raramente correspondem, de fato, às necessidades vitais da comunidade como um todo. No entanto, tais medidas contam, em média, com as pressões abertas ou dissimuladas da propaganda organizada. Além disso, quase sempre se beneficiam de alguma popularidade, em virtude das vantagens inegáveis, que podem assegurar a nações que lutam contra os problemas do após-guerra ou do subdesenvolvimento econômico, político e social" ${ }^{\text {,57. }}$.

Florestan Fernandes indaga se os sociólogos devem aceitar essa posição nacionalista ou defender uma opção autônoma frente à ideologia das camadas sociais dominantes que capitalizam os benefícios do desenvolvimento social.

Outro ponto de divergência com o ISEB surge através da polêmica entre Florestan Fernandes e Guerreiro Ramos. Conforme Maria Arminda Arruda:

"De um lado, o professor paulista, convencido de que somente a partir de procedimentos científicos rigorosos e dotados de princípios gerais é possível pensar os problemas na sua própria sociedade. (...) De outro, o intelectual baiano, radicado no Rio de Janeiro, propugnando por um pensamento sociológico autônomo frente ao produzido no estrangeiro e comprometido com a realidade nacional",58.

A autora apresenta no seu trabalho duas citações bastante características das posições de Florestan Fernandes e Guerreiro Ramos:

"É patente que nenhum cientista conseguirá por a ciência a serviço da sua comunidade, sem observar, de modo íntegro e rigoroso, as normas e os valores que regulam a descoberta, a verificação e a aplicação do conhecimento científico. A esse

\footnotetext{
${ }^{56}$ Florestan FERNANDES, Mudanças Sociais no Brasil, p. 11-49. Este artigo foi apresentado no Seminário sobre Resistência à Mudança: fatores que dificultam ou impedem o desenvolvimento, realizado pelo Centro Latino-Americano de Pesquisas em Ciências Sociais, da UNESCO, em 22 de outubro de 1959.

${ }^{57}$ Ibidem, p. 16.

${ }^{58}$ Maria Arminda do Nascimento ARRUDA, A sociologia no Brasil: Florestan Fernandes e a escola paulista, História das ciências sociais no Brasil, vol. 2, p. 153.
} 
respeito, é justamente o sociólogo que pode estabelecer que, neste terreno, não há incompatibilidade entre o grau de desenvolvimento da estrutura social e a natureza do pensamento científico" "59 (Florestan Fernandes).

Para Guerreiro Ramos "a essência de toda Sociologia autêntica é, direta ou indiretamente, um propósito salvador e de reconstrução social... Desvinculada de uma realidade humana efetiva, a sociologia é uma atividade lúdica da mesma natureza do pifpaf ${ }^{\prime, 60}$. Conforme este autor, a principal atribuição dos intelectuais brasileiros era fundar uma ciência nacional autêntica, não apenas científica, mas voltada para a transformação prática da estrutura social brasileira.

Segundo Daniel Pécaut, "a mediação institucional significou sobretudo a preservação de um hiato entre a formulação de propostas teóricas e a militância política" ${ }^{\text {"61 }}$. No ISEB (Rio de Janeiro) o papel do intelectual envolvia a participação direta no campo político e a reivindicação de uma representatividade popular e nacional. Por outro lado, na Universidade de São Paulo, o papel do intelectual remetia à inserção num meio específico de interreconhecimento e à referências a normas gerais do trabalho teórico.

Sérgio Miceli compara a produção intelectual paulista e a carioca com as seguintes considerações:

"Enquanto, em São Paulo, os cientistas sociais atuantes na ELSP e na USP como pesquisadores e docentes encontraram aí um emprego de tempo integral, seus contemporâneos isebianos (alguns nem mesmo pertencem à universidade) fazem de seus encargos acadêmicos um bico prestigioso entre inúmeras outras atividades, cargos, atribuições e negócios pessoais. (...) Enquanto na capital federal vai se construindo uma hierarquia de objetos e problemáticas em função de sua relevância para o debate político mais amplo, o que equivale a dar prioridade aos conteúdos em detrimento dos procedimentos científicos, em São Paulo logo prevaleceu uma hierarquia propriamente acadêmica privilegiando os métodos de apropriação científica e os focos de interpretação, substituindo a relevância política pela excelência intelectual. (...) Prevalecia no Rio de Janeiro uma concepção 'intervencionista', 'militante' e 'aplicada', cuja expressão intelectualmente acabada são as teorias desenvolvimentistas, enquanto em São Paulo parece se impor uma preocupação marcante com o treinamento metodológico, as leituras dos clássicos, o trabalho de campo individual ou em equipe e toda uma socialização acadêmicodisciplinar então sob hegemonia do paradigma sociológico funcionalista" ${ }^{22}$.

\footnotetext{
${ }^{59}$ Florestan FERNANDES, O padrão de trabalho científico dos sociólogos brasileiros, p. 59, apud Maria Arminda do Nascimento ARRUDA, A sociologia no Brasil: Florestan Fernandes e a escola paulista, História das ciências sociais no Brasil, vol. 2, p. 153.

${ }^{60}$ Alberto Guerreiro RAMOS, Cartilha brasileira do aprendiz de sociólogo. (Prefácio a uma Sociologia nacional). Rio de Janeiro, Andes, 1954, p. 78, apud Maria Arminda do Nascimento ARRUDA, op.cit., p. 153.

${ }^{61}$ Daniel PÉCAUT, Os intelectuais e a política no Brasil, p. 215.

${ }^{62}$ Sérgio MICELI, Por uma sociologia das ciências sociais, História das ciências sociais no Brasil, vol. 1, p. 8292.
} 
Complementando essas afirmações de Sérgio Miceli, Maria Hermínia Tavares de Almeida afirma:

"Ensino e esforços de pesquisa tenderam a se divorciar nas instituições dedicadas às Ciências Sociais no Rio de Janeiro no período estudado, em claro contraste com a experiência que, bem ou mal, se desenvolvia em São Paulo. Separadas, docência e investigação, se domiciliaram em instituições que um conjunto de condições tornava muito vulneráveis às circunstâncias políticas "63.

Todas as informações apresentadas acima colaboram para formar um quadro que contrasta a intelectualidade paulistana, vinculada à Universidade de São Paulo e à ELSP, e os isebianos. Em São Paulo, ensino e pesquisa na área de Ciências Sociais eram realizados nas mesmas instituições, que agregavam profissionais contratados em tempo integral, que valorizavam a adoção de procedimentos científicos, respeitando uma hierarquia acadêmica e ocupados em fazer um "reconhecimento da realidade empírica" de um país que em transição de um mundo tradicional para um mundo moderno. No Rio de Janeiro, ensino e pesquisa estavam desvinculados, sendo que a pesquisa era realizada em uma instituição que dava prioridade aos conteúdos políticos, desenvolvendo um "saber engajado", comprometido com a emancipação política e econômica do país.

\section{O CRPE/SP e o ISEB.}

As considerações feitas no item anterior a respeito das divergências entre o ISEB e os intelectuais paulistas que atuavam junto à Universidade de São Paulo e à Escola Livre de Sociologia e Política, na segunda metade da década de 50, servem de ponto de partida para algumas considerações que podem ser feitas a respeito da existência ou não de relações entre a ideologia nacional-desenvolvimentista do ISEB e a compreensão que os intelectuais que atuavam no Centro Regional de Pesquisas Educacionais de São Paulo tinham a respeito dos problemas educacionais brasileiros.

O primeiro fato que deve ser levado em consideração é que o CRPE/SP era vinculado, por convênio, à Universidade de São Paulo que, através da Faculdade de Filosofia, Ciências e Letras, era responsável por sua administração. O Primeiro Conselho de Administração do Centro era formado pelos professores Egon Schaden e Florestan Fernandes (eleitos pelo Departamento de Sociologia e Antropologia da FFCL/USP), José Querino Ribeiro e Laerte

\footnotetext{
${ }^{63}$ Maria Hermínia Tavares de ALMEIDA, Dilemas da institucionalização das ciências sociais no Rio de Janeiro, História das ciências sociais no Brasil, vol. 1, p. 215.
} 
Ramos de Carvalho (eleitos pelo Departamento de Pedagogia) e Antonio Candido e Milton da Silva Rodrigues (escolhidos por Fernando de Azevedo, mas também vinculados à FFCL/USP). Além disso, os Diretores de Divisão eram, ou haviam sido, professores da Universidade, e os pesquisadores também eram formados pela Faculdade de Filosofia da USP. Cabe lembrar que Renato Jardim Moreira, Diretor da Divisão de Estudos e Pesquisas Sociais, foi assistente de Florestan Fernandes e participou com ele do projeto sobre relações raciais financiado pela UNESCO. Outro dado importante é que prédio em que o Centro funcionava foi uma das primeiras edificações construídas na Cidade Universitária da USP. Assim, percebe-se que o vínculo entre a FFCL/SP e o CRPE/SP não era somente institucional, mas também relativo à todo o corpo de pessoal técnico e administrativo. Este vínculo é um elemento fundamental para a compreensão das relações entre o ISEB e o CRPE/SP.

Por outro lado, o CRPE/SP não surgiu independentemente, ele fazia parte do projeto de criação do Centro Brasileiro de Pesquisas Educacionais e de outros Centros Regionais. O CBPE e os Centros Regionais eram órgãos de pesquisa do Instituto Nacional de Estudos Pedagógicos (INEP), que fazia parte do Ministério da Educação do Governo Kubitschek. O ISEB também era subordinado ao Ministério da Educação, mas tinha autonomia administrativa e liberdade de opinião garantidas nos seus estatutos.

Anísio Teixeira é a figura que está presente, ao mesmo tempo, em todas essas instituições. Ele era diretor do INEP, criador e diretor do CBPE e membro do Conselho Curador do ISEB, além de presidente da CAPES (Coordenação de Aperfeiçoamento de Pessoal de Ensino Superior).

O processo de criação do CBPE, dos Centros Regionais e do ISEB já foi apresentado em partes anteriores deste trabalho. Entretanto, a origem dos recursos financeiros para a criação dessas instituições precisa ser lembrada. Segundo Maria Hermínia Tavares de Almeida, "os recursos eram, basicamente, de três ordens - influência política, poder político e contatos internacionais - todos relacionados às histórias de vida da maioria dos construtores de instituições" ${ }^{64}$. A autora utiliza-se de Anísio Teixeira para exemplificar essa afirmação:

“Anísio Teixeira usou o poder de que dispunha na direção do INEP para criar o CBPE, que nasceu com apoio entusiástico e grande envolvimento da UNESCO. Da mesma forma, foi Anísio na presidência da CAPES, quem proporcionou os recursos necessários à decolagem do IBESP, cujo grupo fundador possuía laços estreitos com os técnicos de assessoria econômica de Vargas e que desempenharam papel de relevo

\footnotetext{
${ }^{64}$ Ibidem, p. 207.
} 
no governo Kubitschek. Foram contatos dessa natureza que permitiram que o ISEB pudesse, posteriormente, ser 'encampado' pelo Ministério da Educação" 65 .

A autora também menciona que as instituições do Rio de Janeiro (CBPE e ISEB) desenvolveram-se à margem da universidade, sendo tentativas de promover as ciências sociais fora do ambiente acadêmico. Como vimos anteriormente, o ISEB deveria promover uma sociologia "engajada", comprometida com a emancipação política do Brasil. O CBPE, de Anísio Teixeira, deveria realizar pesquisas sociais e educacionais que colaborassem para a reconstrução educacional do país. Nesse sentido, essas instituições tinham algo em comum, uma vez que sua produção não se destinava, primordialmente, à comunidade acadêmica e estava comprometida com o desenvolvimento do país.

O CRPE/SP também participava deste "ambiente intelectual" favorável ao desenvolvimento econômico e social do país, característico do governo Kubitschek ${ }^{66}$. Entretanto, a semelhança com as idéias defendidas pelo ISEB reduzem-se a esse aspecto mais geral da análise. A partir daí, seus vínculos com a Faculdade de Filosofia da USP se tornam preponderantes para a caracterização das atividades desenvolvidas.

Os pesquisadores do CRPE/SP, ao justificar seus projetos de pesquisa, sempre enfatizavam o caráter científico de suas proposições, procurando estabelecer critérios considerados cientificamente válidos através do estudo das teorias psico-pedagógicas e sociológicas em uso no meio acadêmico da época. Essa característica fez com que alguns trabalhos de pesquisa do Centro servissem de ponto de partida para teses acadêmicas que se desenvolveriam mais tarde, na USP. Os trabalhos de Luiz Pereira são um exemplo característico dessa afirmação.

Florestan Fernandes, em um depoimento em que faz referência à criação do CRPE/SP, afirma que o Centro "suplementou" a Faculdade de Filosofia e a Universidade de São Paulo nas áreas de atualização de professores e pesquisa científica voltada para a reconstrução educacional do país, áreas "que jamais elas [USP e FFCL] poderiam desenvolver por sua própria conta",67.

\footnotetext{
${ }^{65}$ Ibidem, p. 207.

${ }^{66}$ A esse respeito, Marcos Cezar de Freitas faz, em seu trabalho de pós-doutorado, considerações a respeito da "idéia de tempo histórico" que pode ser considerada comum entre os isebianos e os intelectuais do CBPE. Ver: Marcos Cezar de FREITAS, Da idéia de regional no projeto do Centro Regional de Pesquisas Educacionais de São Paulo, p. 79-89.
} 


\section{Considerações gerais.}

Em relação à ideologia desenvolvimentista do governo Kubitschek, pode-se dizer que seus aspectos centrais eram a "prosperidade", que seria proporcionada pelo desenvolvimento econômico nos moldes capitalistas, e a "ordem", entendida como sendo a manutenção do regime democrático no país. A prosperidade e a ordem garantiriam a soberania da Nação frente aos países estrangeiros.

No embate entre as forças tradicionalistas e as forças favoráveis à modernização do país, o planejamento foi proposto enquanto mecanismo de aceleração do crescimento econômico, uma vez que proporcionaria elementos de controle e previsão, aumentaria a eficiência do sistema e atenuaria os "pontos de estrangulamento" detectados pelo governo.

$\mathrm{Na}$ área educacional, o governo apresentava a intenção de adequar o sistema educacional às exigências do desenvolvimento econômico, entendendo que havia uma interdependência entre educação e desenvolvimento. Com o intuito de aumentar a produtividade nacional, incentivava-se o ensino técnico e pretendia-se ampliar o ensino primário para seis anos. Em relação ao financiamento da educação, o governo destinava recursos às escolas públicas e privadas, sem definir uma linha de atuação.

No Centro Regional de Pesquisas Educacionais de São Paulo, também acreditava-se na necessidade do planejamento para que fosse possível a reconstrução educacional no país. Entretanto, o planejamento não era entendido apenas como um instrumento econômico, ele serviria para fundar, em bases científicas, uma nova política educacional. No CRPE/SP, havia um compromisso entre o planejamento da ação política e a investigação social.

Um exemplo desse tipo de compreensão a respeito do planejamento pode ser observado nos estudos realizados no Centro a respeito da possibilidade de expansão da escolaridade primária para seis anos. Esses estudos indicam que antes de se pensar em estender a escolaridade (de 4 para 6 anos), deveria haver uma preocupação em oferecer efetivamente 4 horas de aula por dia, em classes com no máximo 35 alunos e em prédios adequados, o que não ocorria na época ${ }^{68}$.

No Simpósio sobre Problemas Educacionais Brasileiros, vários trabalhos indicavam que havia a necessidade de elaborar não apenas um sistema de ensino que servisse à industrialização, mas "projetar um tipo de educação que sirva à industrialização enquanto

\footnotetext{
${ }^{67}$ Florestan FERNANDES, Florestan Fernandes, p. 36 .

${ }^{68}$ ALGUNS característicos da escola primária no município de São Paulo, em 1956, Pesquisa e Planejamento, n. 3, p. 119-20.
} 
processo integrado noutro mais geral: o de transformação de toda a estrutura sócioeconômica" ${ }^{69}$, isto é, a transformação de uma economia de base agrária em uma economia nacional de base capitalista.

Em relação à questão do financiamento da educação, a posição dos intelectuais do Centro era claramente definida: defendia-se a idéia de que recursos públicos fossem destinados exclusivamente para a escola pública e que a Lei de Diretrizes e Bases da Educação Nacional dispusesse sobre as competências educacionais da União, Estados e Municípios e sobre os recursos a serem aplicados nos serviços públicos de educação.

Para a ideologia nacional-desenvolvimentista do ISEB, o desenvolvimento nacional alcançaria uma fase superior quando aqui se instaurasse completamente o modo de produção capitalista desenvolvido e autônomo. Para intelectuais como Hélio Jaguaribe, o capitalismo superaria todas as contradições na sociedade, uma vez que os interesses das classes dominantes seriam os mesmos das camadas populares, ou seja, a realização do desenvolvimento econômico nacional.

Além de apresentar sérias dificuldades teóricas - por anular as diferenças de classe $^{70}$ essas afirmações dos intelectuais do ISEB não levavam em consideração os desequilíbrios gerados pela industrialização e urbanização do país. O Manifesto dos Educadores de 1959, elaborado por Fernando de Azevedo, indica que as mudanças econômicas e sócio-culturais que se produziram levaram à desequilíbrios e desajustamentos entre, por exemplo, o sistema de educação e a estrutura demográfica e industrial do país. Essa situação exigia que grandes mudanças no sistema educacional fossem executadas para que esse sistema pudesse atender às exigências da sociedade urbana e industrial.

Essas considerações a respeito da questão do planejamento, do financiamento da educação e dos problemas do desenvolvimento capitalista na Brasil, foram apresentadas com a intenção de sugerir a existência de algumas semelhanças em termos de idéias gerais, mas várias divergências em relação às estratégias de ação sugeridas pela política

\footnotetext{
${ }^{69}$ Fernando Henrique CARDOSO e Octávio IANNI, As exigências do processo de industrialização, Estudos $e$ Documentos, vol. 6, p. 201.

${ }^{70}$ Ver crítica ao ISEB em Maria Sylvia de Carvalho FRANCO, O tempo das ilusões, Ideologia e mobilização popular, p. 151-209.
} 
desenvolvimentista do governo $\mathrm{JK}$, pela ideologia do desenvolvimento do ISEB e pelas propostas elaboradas pelos pesquisadores do CRPE/SP. 


\section{CONCLUSÃO.}

"Mando-lhe estas idéias escritas assim ao correr da pena, para lhe significar quanto penso poder o Centro se tornar algo de concreto e prático no auxílio ao magistério e às escolas. Tudo está em substituir a idéia de reformar a escola por preceitos, ou ordens, ou determinações, ou normas, pela idéia de reformá-la pela mudança de condições, pelos nossos recursos oferecidos e pela transformação das idéias dos professores", . (Anísio Teixeira)

Estas considerações de Anísio Teixeira a respeito do papel que o Centro Regional de Pesquisas Educacionais de São Paulo poderia assumir no processo de renovação educacional paulista e brasileiro servem para sintetizar a idéia geral que norteou a criação e os trabalhos desenvolvidos ao longo dos primeiros anos de atividades dessa instituição.

Na segunda metade dos anos 50, o Brasil vivia um intenso processo de urbanização e industrialização, característico do governo Juscelino Kubitschek. Nesse contexto, Anísio Teixeira e um grupo de intelectuais ligados às Ciências Sociais e à Educação encontraram um ambiente propício para colocar em prática suas idéias de transformação educacional, no sentido de expandir e democratizar o acesso ao ensino e adequá-lo às novas necessidades trazidas pela sociedade industrial.

Ao criar os Centros de Pesquisas Educacionais, Anísio Teixeira acreditava na possibilidade de funcionamento de um conjunto de instituições de pesquisa sem precedentes no Brasil, no qual prevaleceria o chamado espírito universitário, com "pessoas livres, imaginativas, abertas, estudando e documentando o problema brasileiro de educação"2. No Centro Regional de Pesquisas Educacionais de São Paulo, especificamente, o grupo de pesquisadores que se reuniu em função dos trabalhos desenvolvidos nas Divisões de Estudos e Pesquisas Educacionais e Sociais acreditava na possibilidade de utilizar a Educação como uma técnica de intervenção racional e democrática na realidade. Em São Paulo, o CRPE surgiu como uma oportunidade de utilização do conhecimento científico para que, através do planejamento educacional, as necessidades sociais vinculadas à educação fossem atendidas.

Esse propósito de vincular o trabalho de pesquisa às necessidades sociais identificadas pelos intelectuais que trabalhavam no Centro, fez com que ele se tornasse uma instituição que procurava colocar os recursos fornecidos pelas Ciências Sociais à serviço da Educação e,

\footnotetext{
${ }^{1}$ Trecho de Carta de Anísio TEIXEIRA a Fernando de Azevedo, de 24 de outubro de 1956, Arquivo Fernando de Azevedo, IEB/USP (grifos do autor).

2 Trecho de carta de Anísio Teixeira a Péricles Madureira de Pinho, apud Hermes LIMA, Anísio Teixeira: estadista da educação, p. 193.
} 
nesse sentido, colaborou para o desenvolvimento da pesquisa educacional que foi feita, a partir de então, no Brasil.

Os cursos promovidos pela Divisão de Aperfeiçoamento do Magistério também tinham o propósito de colaborar no processo de renovação educacional, através da divulgação aos professores, diretores, delegados de ensino e inspetores escolares vinculados à escola primária os princípios de uma pedagogia que procurava levar em conta a realidade social, política e econômica da época, enfatizando os métodos de pesquisa científica e os princípios do planejamento educacional, além de estimular a valorização individual do aluno, considerando os conhecimentos que ele possui e a forma como ele se desenvolve e aprende como dados fundamentais de observação e análise.

Considerando os propósitos das atividades desenvolvidas pelo CRPE/SP, apresentados acima, cabe ressaltar os problemas enfrentados por essas atividades - sobretudo aquelas relacionadas diretamente às Divisões de Pesquisas - durante o processo de sua concretização.

Os problemas enfrentados pelas Divisões de Pesquisas para realizar os trabalhos propostos refletem a distância entre o projeto de Anísio Teixeira e as condições de realização existentes no Centro Regional paulista.

Na carta encaminhada a Fernando de Azevedo, em outubro de $1956^{3}$, Anísio Teixeira revela claramente a sua compreensão a respeito dos objetivos que o CRPE/SP deveria assumir ao longo de suas atividades. Para ele, a escola brasileira teria suas condições de existência profundamente alteradas através do levantamento sistemático de dados, da reflexão científica a respeito dos problemas existentes e da preparação de materiais de ensino que auxiliassem o professor a transformar suas idéias a respeito da educação.

O vínculo estabelecido com a Universidade de São Paulo através de convênio era outro ponto fundamental do projeto. Através desse convênio, a Universidade assumia a responsabilidade de sua execução, enquanto que o INEP deveria apenas verificar o seu cumprimento. Este acordo fazia com que a Universidade - através da Faculdade de Filosofia, Ciências e Letras - indicasse e oferecesse ao Centro o Diretor Geral e os membros do Conselho de Administração (mais tarde o Conselho Consultivo). Além disso, na prática, quase todos os pesquisadores, chefes de seção e estagiários também tinham, ou haviam tido, algum vínculo com a Faculdade de Filosofia. Como apresentado no Capítulo 7 deste trabalho, o Centro suplementava esta Faculdade em áreas que ela não desenvolveria por conta própria: a

\footnotetext{
${ }^{3}$ Esta carta encontra-se reproduzida no Anexo C.
} 
atualização de professores de nível médio (através de seus cursos) e a pesquisa científica voltada para a reconstrução educacional brasileira (através das pesquisas).

Ao vincular o Centro à Universidade, Anísio Teixeira conseguiu colocar em prática outro elemento do seu projeto: atrair vários intelectuais de renome da Faculdade de Filosofia para o estudo dos problemas educacionais brasileiros. Esses intelectuais - Fernando de Azevedo, Florestan Fernandes, Dante Moreira Leite, entre outros - acreditaram no alcance do projeto sugerido e se dispuseram a colaborar com os objetivos do Centro, atribuindo-lhe credibilidade e notoriedade frente à comunidade acadêmica e aos meios intelectuais e políticos brasileiros.

Entretanto, as condições de realização efetivamente existentes no Centro não alcançaram o nível de eficiência necessário à concretização dos objetivos propostos. No período de 1956 a 1961, o Levantamento do Ensino Primário foi a principal pesquisa desenvolvida pela Divisão de Estudos e Pesquisas Sociais e a elaboração da Ficha de Observação de Alunos e das Escalas de Escolaridade foram os principais projetos da Divisão de Estudos e Pesquisas Educacionais. Entretanto, observa-se que, com exceção da Ficha de Observação de Alunos, várias pesquisas propostas por essas Divisões não chegaram a ser concluídas ou foram concluídas de forma parcial ou modificada em relação à proposta original, gerando alguns resultados considerados "frustrantes" pelos pesquisadores. Cabe lembrar que o projeto inicial do Levantamento do Ensino Primário previa a obtenção de diversos dados sobre uma amostra de escolas primárias de todo o Estado de São Paulo, sendo que foi possível apenas o levantamento de dados de uma amostra das escolas da Capital.

Diversas razões podem ser apontadas para a explicação das condições de realização existentes: falta de recursos materiais e humanos; inexperiência dos pesquisadores; inexistência de dados suficientes para análise nos órgãos oficiais; dificuldades de realização de convênios com a Secretaria de Educação; falta de colaboração por parte de professores e diretores de escolas; etc. Outra explicação para o nível de realização alcançado pelas pesquisas do Centro foi apresentada por Raja Nassar no Simpósio sobre Problemas Educacionais Brasileiros, de 1959. Raja Nassar acreditava que a grande dificuldade enfrentada pelo Centro era a ausência de um programa definido de atividades que tornasse claro os principais problemas educacionais que seriam tratados ao longo de suas atividades. Essa "improvisação" na escolha dos problemas e a falta de um esquema de representação teórica da realidade que se pretendia investigar seriam as causas da pequena contribuição à solução dos problemas educacionais resultante do trabalho desenvolvido no CRPE/SP. Além disso, a 
ausência de um programa de atividades melhor definido impossibilitava a articulação entre as divisões de pesquisa e entre os Centros Regionais e o CBPE, no sentido da realização de trabalhos cujos resultados fossem cumulativos e contribuíssem para a continuidade das pesquisas educacionais.

$\mathrm{Na}$ realidade, o CRPE/SP possuía um plano de trabalho que estabelecia as diretrizes gerais para as atividades que seriam desenvolvidas. Entretanto, esse plano não determinava, especificamente, um cronograma de pesquisas e cursos ou os procedimentos que deveriam ser utilizados para a sua realização. O plano de trabalho restringia-se a fazer orientações gerais, como: "empreender pesquisas de interesse para a educação"; "promover experiências de novas técnicas de ensino"; "promover planejamentos de reconstrução educacional"; e, "auxiliar e esclarecer os professores sobre os problemas de educação".

Essa ausência de um plano específico de trabalho foi característica dos primeiros anos de existência do Centro, quando ele estava em fase de instalação e em processo de delimitação de atividades. Tentativas de realização de pesquisas amplas - como o Levantamento do Ensino Primário - surgiam em função da necessidade observada pelos pesquisadores de suprir o Estado com dados fundamentais, primários, para as pesquisas educacionais. No entender dos pesquisadores do Centro, a forma de apresentação dos dados disponíveis no Departamento de Estatística da Secretaria da Educação e no IBGE impediam a realização das análises pretendidas.

Em relação aos recursos financeiros disponíveis, pode-se dizer que eles foram escasseando com o passar dos anos e com as alterações efetuadas na política econômica do governo. Como o plano de trabalho estabelecia objetivos muito amplos, os projetos foram sendo modificados ou abandonados para adaptar as atividades do Centro à realidade de condições existente. Essa situação evoluiu até o ponto em que os Diretores de Divisão foram se desligando do Centro, por não encontrarem nele as condições julgadas necessárias para a realização dos grandes projetos. Entretanto, os problemas financeiros eram apenas uma das dificuldades apontadas. Apontava-se também a existência de problemas organizacionais e administrativos do Centro, que dificultavam o andamento das pesquisas e a passagem para um nível mais sofisticado de análise dos dados obtidos através dos levantamentos. Entre os anos de 1960 e 1961 diversos pesquisadores do quadro técnico do Centro se afastaram e, em sua maioria, passaram a dar continuidade às suas carreiras profissionais nas Universidades paulistanas. 
A inexperiência do quadro técnico do Centro era outro fator que caracterizava as suas condições reais de funcionamento. A maioria dos assistentes e auxiliares de pesquisa era constituída por recém formados da Faculdade de Filosofia, Ciências e Letras e estava em processo de amadurecimento profissional. Esse aspecto, entretanto, é um importante elemento para a melhor compreensão dos resultados obtidos pelas atividades do CRPE/SP, no período de 1956 a 1961.

Se, por um lado, a maioria das pesquisas realizadas não apresentou resultados conclusivos ou não conseguiu atingir os objetivos propostos em seus projetos iniciais, por outro lado, elas influenciariam a formação dos pesquisadores que delas participaram e as pesquisas que se desenvolveriam, posteriormente, na própria Faculdade de Filosofia, Ciências e Letras da Universidade de São Paulo.

Os jovens estagiários e auxiliares de pesquisas do Centro tinham a oportunidade de participar de várias etapas dos projetos de pesquisa desenvolvidos, recebendo orientações teóricas e práticas que os auxiliavam na realização de seus trabalhos. Ao mesmo tempo, através das visitas às escolas para coleta de dados, eles entravam em contato direto com os problemas educacionais da cidade de São Paulo e com as propostas de solução desses problemas elaboradas pelos pesquisadores mais experientes. Essa complementação da formação acadêmica, tornada possível pelo trabalho junto ao Centro, serviu para dar aos pesquisadores iniciantes uma experiência prática de investigação, que marcaria de forma decisiva suas trajetórias profissionais, atraindo-os para o estudo das questões educacionais brasileiras.

Esse processo de formação e seus resultados posteriores podem ser percebidos no início da trajetória profissional e nos primeiros trabalhos acadêmicos produzidos por alguns dos pesquisadores do Centro, como José Mario Pires Azanha, Jorge Nagle, Maria do Carmo Guedes, Ruth Cardoso, Celso Beisiegel, Luiz Pereira, Perseu Abramo e outros.

José Mário Pires Azanha formou-se no curso de Pedagogia da Faculdade de Filosofia, Ciências e Letras da USP em 1955. Em 1957, começou a trabalhar no Centro, como Assistente de Pesquisa da Divisão de Estudos e Pesquisas Educacionais. Durante o período de 1957 a 1961, participou do projeto de elaboração da Ficha de Observação de Alunos, dos estudos experimentais sobre problemas aritméticos na escola primária e de cursos promovidos pelo Centro. A partir de 1963, ainda no Centro, coordenou o PATE (Programa de Assistência Técnica em Educação), que orientava equipes de professores para atuar no desenvolvimento da educação em vários Estados do Norte e Nordeste. Em 1966, assumiu o cargo de Diretor- 
Substituto do Centro e, de 1967 a 1970, chefiou a Coordenadoria do Ensino Básico e Normal da Secretaria de Educação do Estado de São Paulo. $O$ conceito de experimentação educacional (uma contribuição à sua análise) foi sua tese de Doutorado em Educação, defendida em 1972.

Jorge Nagle, também formado em Pedagogia pela FFCL/USP, começou a trabalhar no Centro em 1958, atuando em alguns cursos e coordenando as Classes Experimentais até 1961. Sua tese de Livre-Docência foi apresentada em 1966, sob o título Educação e Sociedade no Brasil (1920-1929).

Maria do Carmo Guedes formou-se em Filosofia e começou a trabalhar, como Auxiliar de Pesquisa da Divisão de Estudos e Pesquisas Educacionais do Centro em 1957. Participou da elaboração das Escalas de Escolaridade e de outras pesquisas dessa Divisão. Em 1961, passou a ser responsável pela DEPE. A partir de 1962, começou a lecionar na Pontifícia Universidade Católica de São Paulo, inicialmente no curso de Filosofia e, mais tarde, no curso de Psicologia. Sua tese de Doutorado, apresentada em 1974, foi intitulada Programação e Análise de Contingências para Grande Número de Alunos.

Ruth Cardoso começou a trabalhar no Centro em 1958. Antes disso, em 1957, ela desenvolveu uma pesquisa financiada pelo Centro - Associações de "nissei” em São Paulo que contribuiria para a realização de sua dissertação de mestrado, apresentada em 1970: $O$ papel das associações juvenis na aculturação dos japoneses. No seu Doutorado, de 1972, a autora continuou estudando os japoneses: Estrutura familiar e mobilidade social: estudos dos japoneses no Estado de São Paulo

Celso Beisiegel começou a trabalhar na Divisão de Estudos e Pesquisas Sociais do Centro em 1957, ainda como estagiário. Formado em Ciências Sociais na FFCL/USP, concluiu seus estudos de especialização em Sociologia, em 1964, com um trabalho iniciado no Centro: Ação política e expansão da rede escolar. No ano de 1963, trabalhando no CRPE, Celso Beisiegel teve a oportunidade de conhecer a cidade de Angicos, no Rio Grande do Norte, onde entrou em contato com uma experiência de alfabetização de adultos através do "método Paulo Freire". A alfabetização de adultos seria objeto de estudo de sua tese de Doutorado - A educação de adultos no Estado de São Paulo - e de Livre-Docência Política e educação popular.

Luiz Pereira, também formado em Ciências Sociais pela Faculdade de Filosofia, Ciências e Letras da USP, começou a trabalhar no CRPE/SP em 1957, na Divisão de Estudos e Pesquisas Sociais. Em 1960, Luiz Pereira concluiu seus estudos de especialização em 
Sociologia com a monografia A escola numa área metropolitana. No ano seguinte, apresentou sua tese de doutorado O magistério primário numa sociedade de classes e, em 1962, publicou o trabalho Nota crítica sobre o pensamento pedagógico brasileiro.

Perseu Abramo foi um dos primeiros assistentes de pesquisa contratados pelo Centro, ainda em 1956. Em 1958, ele concluiria sua graduação em Ciências Sociais pela Faculdade de Filosofia e dedicaria sua carreira ao jornalismo. Entretanto, sua participação no CRPE/SP possibilitou o desenvolvimento de atividades jornalísticas voltadas para a educação. No jornal Folha de S. Paulo, Perseu Abramo coordenou a Seção de Educação.

Esses exemplos de trajetórias acadêmicas iniciadas através da formação de pesquisadores ocorrida no CRPE/SP demonstram que as atividades nele desenvolvidas geraram resultados significativos para a pesquisa educacional brasileira: seja através do resultado de algumas pesquisas e cursos bem sucedidos, seja pela influência causada na formação de pesquisadores e em seus trabalhos posteriores.

A partir de 1961, Laerte Ramos de Carvalho assume a direção do Centro e procura estimular a elaboração de projetos menores e planos mais específicos de trabalho, que possibilitassem um melhor desenvolvimento de atividades articuladas entre as divisões de pesquisa e com os demais Centros Regionais e o CBPE. Nesse momento, entretanto, o Centro passava a assumir novas características, com suas atividades cada vez mais intimamente relacionadas às da Faculdade de Filosofia da USP.

A experiência de pesquisa educacional revelada pelas atividades desenvolvidas no CRPE/SP, durante o período de 1956 a 1961, demonstra que já existiu no Brasil uma instituição voltada para a pesquisa educacional que, mesmo vinculada à Universidade, não restringia seus objetivos aos limites das exigências acadêmicas e que contava com recursos humanos e financeiros próprios para estabelecer, de forma independente, linhas de pesquisas convergentes com o propósito de transformação da educação brasileira a partir da análise sistemática de seus principais problemas. 


\section{ANEXO A.}

\section{FOA - FICHA DE OBSERVAÇÃO DE ALUNOS}

Centro Regional de Pesquisas Educacionais - Divisão de Estudos e Pesquisas Educacionais 1957

Instruções - leia com atenção

1. Preencha inicialmente a identificação do aluno e em seguida a do professor, no lugar indicado.

2. Não há necessidade de declarar o nome do professor. Os dados solicitados referem-se exclusivamente ao comportamento dos alunos, não havendo interesse algum em fiscalizar a atuação do professor.

3. Leia o questionário inteiro, desde a primeira até a última questão, procurando dominar bem o significado de cada pergunta. Quanto maior número de vezes o questionário for lido, tanto maior será a facilidade na observação do comportamento e no registro dos dados.

4. Inicie o preenchimento do questionário no dia marcado pelos instrutores.

5. O preenchimento deve ser diário, na base da observação do dia. Não confie na sua memória.

6. As respostas possíveis às perguntas do questionário são: SIM - NÃO - ?. Essas notações serão colocadas adiante de cada pergunta, no quadrado correspondente ao dia da observação.

a) A notação SIM deve ser colocada quando o comportamento em observação DE FATO APARECEU;

b) A notação NÃ̃O deve ser colocada quando o comportamento em observação não apareceu, EMBORA HOUVESSE OPORTUNIDADE;

c) A notação ? deve ser colocada QUANDO NÃO HOUVE OPORTUNIDADE para o aparecimento do comportamento em observação.

7. Todas as perguntas devem ser respondidas.

8. As observações devem ser feitas sem interrupção, durante os dias escolhidos. Quando houver falta do professor ou do aluno, a coluna correspondente ao dia da falta deverá ficar em branco.

9. Registre o comportamento somente quando este for MANIFESTO. Tome cuidado para não registar uma IMPRESSÃO JÁ FORMADA sobre o aluno. 
Identidade do Aluno - preencha todos os campos com letra de fôrma.

1. Nome:

2. Data de Nascimento:

3. Sexo:.......

4. Branco, Preto, Amarelo, Pardo

5. Residência do Aluno:

6. Nacionalidade do pai:

7. Nacionalidade da mãe:

8. Profissão do pai:

9. Profissão da mãe:

10. O pai é vivo? 11. A mãe é viva? 12. Vivem juntos?

13. Posição na constelação familiar:

\begin{tabular}{|l|l|l|}
\hline Irmãos vivos & Mais velhos & Mais Novos \\
\hline Sexo Masculino & & \\
\hline Sexo Feminino & & \\
\hline
\end{tabular}

14. Ano:............15. Classe:............ 16. Masculina, Feminina, Mista

17. É repetente?.............. 18. Quantas vezes repetiu esse ano?

19. Grupo Escolar:

20. Bairro: 21. Cidade:

Identidade do Professor.

1. Data de Nascimento:

2. Sexo 3. Estado Civil

4. Cursos Pós Graduados
4.1. Aperfeiçoamento
4.2. Especialização pré-primária
4.3. Administradores
4.4. Faculdade de Filosofia

4.5. Outro. Qual?

5. Data do ingresso no magistério: a) Como substituto.

b) Como efetivo.

\section{Sugestões do Observador.}

$\mathrm{Na}$ sua opinião os itens são suficientes para se obter uma impressão precisa do comportamento do aluno observado?

SIM NÃO

Se houver algum item que você acha importante que seja acrescentado a este questionário ou se houver alguma outra explicação que você julgue necessária, faça o favor de escrevê-los aqui neste espaço. 
1. Ameaçou ou intimidou os colegas com gestos, palavras ou objetos?

2. Destruiu ou danificou objetos quando foi contrariado?

3. Desfez jogos ou brinquedos quando foi contrariado?

4. Discutiu as notas ou decisões do professor?

5. Concordou e aceitou sugestões apresentadas pelos colegas?

6. Exigiu atenção (fez barulho, gritos, etc.) para seus atos e palavras?

7. Deu ordens aos colegas?

8. "Topou" logo uma encrenca ou discussão quando foi provocado?

9. Tentou impedir ou limitar movimentos e atividades dos colegas?

10. Negou valor (deu risada, caçoou, etc.) aos trabalhos dos colegas ou do professor?

11. Arremedou os colegas com gestos ou palavras?

12. Manifestou preferência por brincar ou trabalhar só? (recusou convites, isolou-se, etc.)

13. Manifestou desagrado (resmungou, retrucou, etc.) quando lhe foi imposta disciplina rigorosa pelo professor?

14. Agrediu fisicamente algum colega da classe (deu ponta-pés, socos, empurrões, atirou objetos, etc.)?

15. Conformou-se (não discutiu, calou-se, etc.) quando perdeu uma disputa?

16. Denunciou os colegas?

17. Pediu auxílio (perguntou sobre a lição, solicitou proteção) aos colegas?

18. Revoltou-se (resistiu, discutiu, brigou) contra os colegas "mandões"?

19. Reagiu (retrucou, discutiu, brigou) quando foi objeto de caçoada ou de acusação por parte dos colegas?

20. Tomou decisões pelos colegas na escolha de tarefas, brinquedos, etc?

21. Xingou ou chamou os colegas por apelidos desagradáveis?

22. Reagiu (ameaçou, gritou, xingou) quando algum colega mexeu no seu material?

23. Insistiu em ser chamado (para apresentar lições, responder perguntas, dar palpites) quando já tinha sido preterido?

24. Reagiu (ameaçou, xingou, resmungou, fez caretas) quando impedido em sua atividade?

25. Foi "palpiteiro" na realização das diversas atividades da escola?

26. Reagiu quando recebeu insultos ou ofensas físicas?

27. Impôs sua participação na atividade dos demais?

28. Chorou quando foi excluído de algum grupo ou atividade?

29. Caçoou dos erros, distrações ou palpites dos colegas?

30. Impôs castigos ou exigiu satisfações dos colegas?

31. Foi pontual no horário e na entrega de trabalhos escolares?

32. Em discussão com os colegas procurou sobrepor-se aos demais?

33. Procurou companhia na realização de tarefas ou brinquedos?

34. Disputou a posse de objetos ou lugares?

35. Ofereceu material ou serviço aos colegas?

36. Participou de vaias ou caçoadas?

37. Ouviu com atenção os colegas quando leram ou relataram algum fato?

38. Recusou ajuda ou conselhos do professor quando estava em dificuldade?

39. Desobedeceu alguma ordem ou advertência do professor?

40. Ofereceu-se para organizar ou dirigir as atividades dos demais?

41. Obrigou os colegas a prestarem serviço, a dar ou emprestar material?

42. Falou continuamente na classe?

43. Aceitou castigos ou executou ordens impostas pelos colegas?

44. Humilhou colegas, referindo-se a fatos desagradáveis sobre os mesmos ou sobre suas famílias?

45. Contou fatos, piadas, ou fez graças para divertir os outros?

46. Ajudou os colegas em alguma tarefa ou brinquedo, sem ser mandado pelo professor?

\begin{tabular}{|l|l|l|l|l|l|l|l|l|l|l|}
\hline & $1 .^{\circ}$ & $2 .^{\circ}$ & $3 .^{\circ}$ & $4 .^{\circ}$ & $5 .^{\circ}$ & $6 .^{\circ}$ & $7 .^{\circ}$ & $8 .^{\circ}$ & $9 .^{\circ}$ & $10 .^{\circ}$ \\
\hline
\end{tabular}




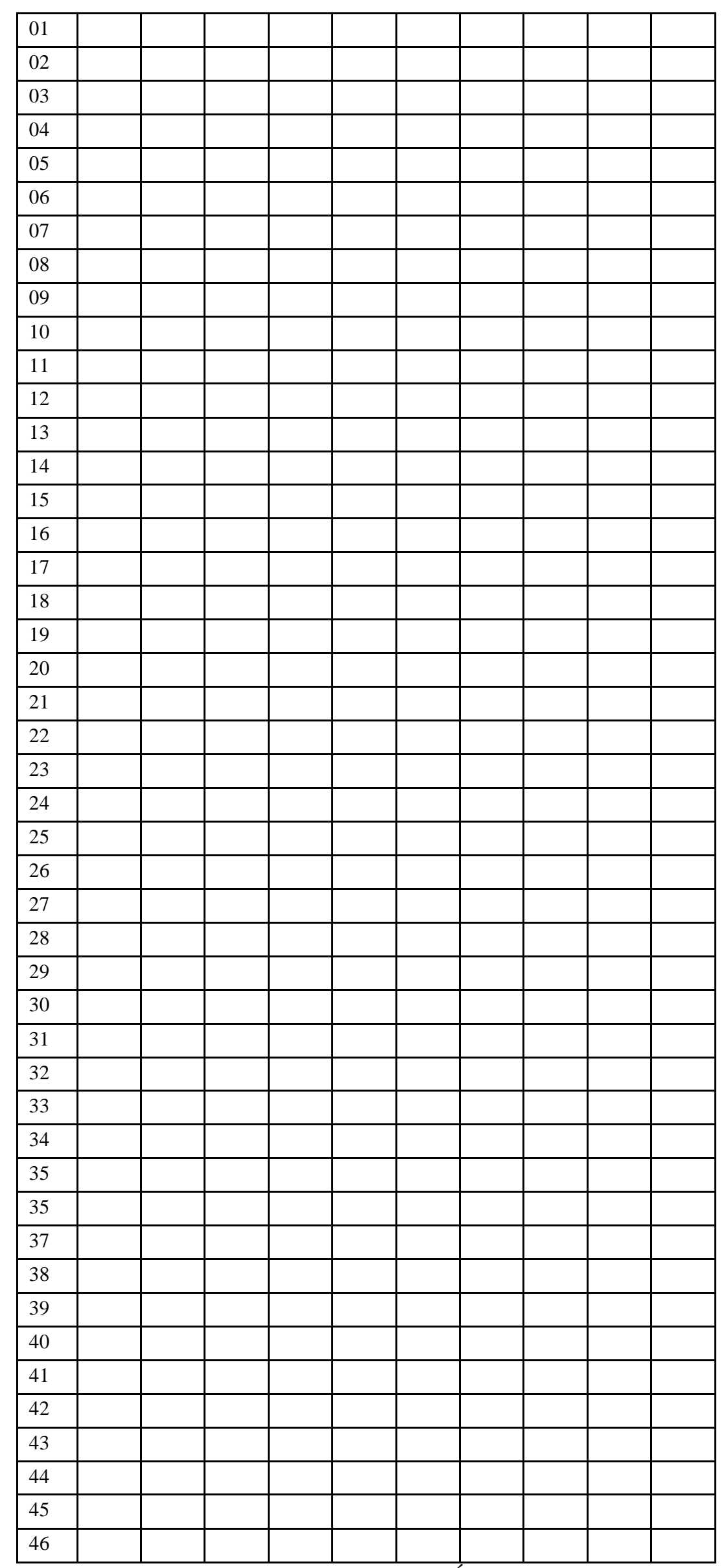

(DOCUMENTO DO CENTRO DE MEMÓRIA/USP - CRPE, DEPES, PAT, CAIXA 3, DOCTO. 46) 


\section{ANEXO B.}

\section{O Simpósio sobre Problemas Educacionais Brasileiros (CRPE/SP - 1959).}

A idéia de realização do Simpósio sobre Problemas Educacionais Brasileiros surgiu em 1955, por ocasião dos debates que se realizaram para a definição dos objetivos do Centro Brasileiro de Pesquisas Educacionais e dos Centros Regionais. Os cientistas sociais de São Paulo sugeriram a discussão do problema de "mudança provocada" na sociedade. "Em seguida, evoluiu-se para a idéia de analisar e estudar a questão tendo em vista a situação social do Brasil",

A sugestão apresentada no ante-projeto do Simpósio, elaborado por Florestan Fernandes, foi a discussão da "validade do que já se conhece a respeito da sociedade brasileira, do papel que nela desempenham as instituições educacionais, bem como, à luz do que for julgado válido, formular as mais aceitáveis recomendações no que se refere à nossa política educacional"2.

Com esse procedimento, ficariam evidentes as deficiências do conhecimento que se tem do país e, consequentemente, seria mais fácil determinar quais as pesquisas e levantamentos mais necessários e urgentes a serem realizados pelo CBPE e seus Centros Regionais. Conforme Florestan Fernandes, "através dos debates em torno das relações entre a realidade social, tal como é conhecida, e o sistema educacional existente, bem como pelos debates sobre a política educacional mais recomendável à luz de tal conhecimento, chegaríamos a positivar até que ponto, em uma sociedade como a nossa, a educação pode contribuir para orientar e dirigir, se é que tal lhe é possível, o processo de desenvolvimento e mudança",3.

Foram estabelecidos três temas principais:

1. Estrutura e mudança social no Brasil;

2. A situação educacional e a realidade social do Brasil; e,

3. Fundamentos de uma nova política educacional para o Brasil.

Esses três temas foram subdivididos em várias questões que seriam distribuídas a um grupo de cientistas sociais e educadores encarregados de preparar comunicações e apresentálas no Simpósio, que se realizaria em julho de 1957.

\footnotetext{
${ }^{1}$ Florestan FERNANDES, “A situação brasileira e a educação”, Educação e Ciências Sociais, n. ${ }^{\circ}$ 4, p. 301.

2 Ibidem, p. 301.

${ }^{3}$ Ibidem, p. 301.
} 
Entretanto, em junho de 1957, realizaram-se apenas reuniões preparatórias para o Simpósio, em que se definiram os temas que seriam apresentados definitivamente. Lourenço Filho seria o presidente de honra do evento que se realizaria em janeiro de 1958.

O Simpósio somente ocorreu em 1959, nos dias 1, 2 e 3 de setembro. Na abertura, os trabalhos foram presididos por Anísio Teixeira. A mesa foi composta por Fernando de Azevedo (Diretor do CRPE/SP), Milton da Silva Rodrigues (catedrático de Estatística da Faculdade de Filosofia da USP e coordenador do Simpósio), Moreira de Sousa (representando Gilberto Freyre, do Centro Regional de Pernambuco), Jayme Abreu (coordenador do CBPE) e Mario Casassanta (do Centro Regional de Minas Gerais).

Os trabalhos apresentados foram os seguintes ${ }^{4}$ :

\begin{tabular}{|c|c|}
\hline \multicolumn{2}{|c|}{$\begin{array}{l}\text { Tema I - Técnicas e problemas da mudança cultural provocada em face da organização e } \\
\text { funcionamento do sistema educacional brasileiro. }\end{array}$} \\
\hline 1. Florestan Fernandes & $\begin{array}{l}\text { A ciência aplicada e a educação como fatores de mudança } \\
\text { cultural provocada. }\end{array}$ \\
\hline 2. Dante Moreira Leite & $\begin{array}{l}\text { A investigação psicológica em face aos problemas educacionais } \\
\text { brasileiros. }\end{array}$ \\
\hline 3. Renato Jardim Moreira & $\begin{array}{l}\text { A investigação social diante dos problemas educacionais } \\
\text { brasileiros. }\end{array}$ \\
\hline 4. João Eduardo Villalobos & $\begin{array}{l}\text { O problema dos valores na formação e no funcionamento do } \\
\text { sistema educacional brasileiro. }\end{array}$ \\
\hline 5. José Querino Ribeiro & $\begin{array}{l}\text { O problema da administração na formação e no desenvolvimento } \\
\text { do sistema escolar brasileiro. }\end{array}$ \\
\hline 6. Carlos Corrêa Mascaro & $\begin{array}{l}\text { O custeio da educação e a utilização de recursos para as reformas } \\
\text { educacionais. }\end{array}$ \\
\hline \multicolumn{2}{|c|}{ Tema II - Diagnóstico de uma situação educacional. } \\
\hline 1. Anísio Teixeira & Os grandes problemas atuais da educação no Brasil \\
\hline 2. Luiz Pereira & Rendimento e deficiências do ensino primário brasileiro. \\
\hline 3. Raja Nassar & Rendimento e deficiências do ensino secundário brasileiro. \\
\hline 4. Moyses Brejon & $\begin{array}{l}\text { Rendimento e deficiências do ensino técnico-profissional } \\
\text { brasileiro. }\end{array}$ \\
\hline 5. Milton da Silva Rodrigues & Problemas atuais do ensino superior no Brasil. \\
\hline \multicolumn{2}{|c|}{ Tema III - A escola como fonte de tensões e fator de desenvolvimento na sociedade brasileira. } \\
\hline 1. Fernando de Azevedo & Educação e mudança social. \\
\hline 2. Duglas Teixeira Monteiro & $\begin{array}{l}\text { Necessidades educacionais de áreas de expansão demográfica da } \\
\text { sociedade brasileira no norte do Paraná. }\end{array}$ \\
\hline 3. Gioconda Mussolini & $\begin{array}{l}\text { A integração da escola em pequenas comunidades rurais no } \\
\text { Brasil. }\end{array}$ \\
\hline 4. Egon Schaden & $\begin{array}{l}\text { A escola teuto-brasileira e a assimilação de imigrantes alemães e } \\
\text { seus descendentes. }\end{array}$ \\
\hline 5. Ruth Correa Leite Cardoso & Necessidades educacionais de áreas em urbanização. \\
\hline $\begin{array}{l}\text { 6. Fernando Henrique Cardoso e } \\
\text { Octávio Ianni }\end{array}$ & Exigências educacionais do processo de industrialização. \\
\hline
\end{tabular}

Na parte introdutória do trabalho que apresentou no Simpósio, Florestan Fernandes comenta esse longo processo de formulação sofrido pelo evento, indicando que no primeiro 
tema sugerido para a sua realização "o que prevalecia era a intenção de examinar como se poderiam explorar construtivamente, no Brasil, os recursos postos a serviço da educação pela ciência ou pela pedagogia baseada no conhecimento científico. $\mathrm{O}$ diagnóstico da situação brasileira constituía um ponto de referência indispensável, tanto para a avaliação da viabilidade das soluções, quanto para a apreciação do tipo de colaboração a ser prestada pelos cientistas sociais"5. Entretanto, no plano definitivo, o eixo do Simpósio passou a ser o próprio diagnóstico da situação educacional brasileira, realizado por educadores e cientistas sociais envolvidos com as atividades do CBPE e dos Centros Regionais.

Esse diagnóstico, de modo geral, apontava os problemas existentes em todos os níveis da educação brasileira da época e indicava que a educação precisava adaptar-se às necessidades características de uma sociedade em mudança para um modelo urbano e industrial.

O principais trabalhos apresentados foram os seguintes: Florestan Fernandes indica em que a Sociologia poderia contribuir para a solução dos problemas educacionais. Dante Moreira Leite, concentra sua atenção nas contribuições da Psicologia. Renato Jardim Moreira, enfatiza a necessidade de realização de levantamentos sobre a situação educacional para que fosse possível a concretização de uma planejamento integral da educação. Luiz Pereira apresenta sua interpretação a respeito do ensino primário brasileiro. $\mathrm{O}$ ensino secundário, industrial e superior tiveram as respectivas análises apresentadas pelos trabalhos de Ruth Cardoso, Fernando Henrique e Octávio Ianni, ao tratarem das necessidades educacionais da sociedade urbanizada e industrializada. Egon Schadem e Duglas Teixeira Monteiro concentram-se na caracterização de alguns aspectos do ensino em áreas rurais em duas regiões do país.

O grande tema que atravessa a maioria dos trabalhos apresentados e que recebeu maior atenção por parte de Florestan Fernandes, Fernando Henrique Cardoso, Octávio Ianni, Luiz Pereira e Fernando de Azevedo é a questão da relação entre a mudança social e a educação em nossa sociedade. Nessa discussão, ganha destaque o papel que os educadores podem assumir no processo de transformação da sociedade brasileira, desde que conscientes de que a escola é uma instituição social cujos problemas somente podem ser resolvidos quando tomados em relação às transformações pelas quais esteja passando a sociedade em geral. Na época em que

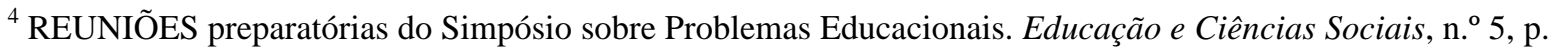
269.

${ }^{5}$ Florestan FERNANDES, A ciência aplicada e a educação como fatores de mudança cultural provocada, Estudos e Documentos, vol. 5, p. 09.
} 
se realizava este Simpósio, o Brasil, e especialmente São Paulo, atravessava um momento de intensa urbanização e industrialização que demandavam uma nova postura dos educadores frente aos problemas educacionais.

Os Centros de Pesquisas Educacionais procuravam colaborar com suas pesquisas e cursos para essa renovação educacional. Entretanto, no Simpósio, a atuação dos Centros também recebeu críticas. A comunicação de Raja Nassar, ao tratar dos problemas do ensino secundário brasileiro, destaca os aspectos negativos da atuação do CBPE e de seus Centros Regionais. Em função do que o autor chama de "ausência de um esquema teórico do processo educativo", desenvolve-se uma crítica à "improvisação" que seria característica da atuação dessas instituições; à falta de um programa de atividades definido; ao caráter "marcadamente pessoal" dos critérios de seleção de problemas a serem investigados; e, à falta de inter-relação entre as pesquisas do Centro Brasileiro e dos Centros Regionais.

\section{Nota referente à publicação dos trabalhos apresentados no Simpósio.}

A publicação conjunta dos trabalhos apresentados neste Simpósio ocorreu quase dez anos após a sua realização, em 1967 e 1968, através da Série Estudos e Documentos, editada pelo CRPE/SP. Alguns trabalhos, entretanto, já haviam sido publicados anteriormente: o artigo de Renato Jardim Moreira foi publicado, parcialmente, em junho de 1959, na revista Pesquisa e Planejamento n. 3 , sob o título "Pesquisa e Política Educacional"; o artigo de Luiz Pereira foi publicado pela Revista da Faculdade de Filosofia, Ciências e Letras de Araraquara n. ${ }^{\circ}$ 1, em 1960; o artigo de Fernando de Azevedo foi publicado no livro A cidade e o campo da civilização industrial e outros estudos, de 1961; e, o trabalho de Florestan Fernandes no livro Ensaios de Sociologia Geral e Aplicada, de 1959.

A Série Estudos e Documentos deixou de publicar dois trabalhos que fizeram parte do Simpósio: “Os grandes problemas atuais da educação no Brasil”, de Anísio Teixeira; e, “A integração da escola em pequenas comunidades rurais no Brasil”, de Gioconda Mussolini. Alguns trechos do trabalho de Anísio Teixeira podem ser encontrados no artigo "Professores iniciam um grande debate sobre os problemas atuais da educação no Brasil”, do jornal $O$ Estado de S. Paulo, de 2 de setembro de 1959. 


\section{ANEXO C.}

\section{Carta de Anísio Teixeira a Fernando de Azevedo, de 24 de outubro de 1956.}

"Rio, 24 de out. 56.

Meu caro Fernando: recebi ontem a sua carta de 21, que muito lhe agradeço. Toda a matéria do início dos trabalhos do Centro sugeriu-me falar-lhe a respeito de certos objetivos, que tenho mais in petto do que expressos, para o nosso trabalho.

Primeiro - a minha idéia de 'pesquisa educacional', além de compreender tudo que é realmente pesquisa, incluiria algo de mais geral, que devia transmitir a todo o sistema escolar, da classe à sala do diretor, a idéia de que todo esse imenso aparelho é um aparelho de coleta e registro de fatos; que tais fatos constituem a matéria prima para a pesquisa; e que, portanto, se forem melhoradas as formas de registro dos fatos e os mesmos se fizerem cumulativos - na escola e na classe se encontrará sempre um material abundantíssimo para o estudo dos alunos, dos métodos e do conteúdo do ensino.

Isto posto, um dos primeiros trabalhos-raízes do Centro seria o preparo de formulário e fichas para o registro de fatos escolares. Substituir o espírito puramente estatístico ou, se quiser, quantitativo dos registros escolares, pelo qualitativo. Haveria então uma ficha do aluno, desenvolvida e cumulativa, que nos daria a história do aluno na escola. Uma ficha idêntica do professor. E, possivelmente, outra de fatos escolares, algo como o diário de bordo de um navio. Com esses três documentos, teríamos sempre um conjunto de fatos seguidos e, repito, acumulados, isto é, longitudinais sobre o aluno, o professor e a escola: verdadeiro tesouro para pesquisas de toda espécie.

Segundo - Além da acumulação desse material, o professor e o diretor da escola seriam instruídos de que eles sempre se poderiam dirigir ao Centro para estudar problemas que lhes tivessem surgido e que não tivessem capacidade de resolver. Deste modo, não seriam apenas coletores de fatos mas pessoas que estariam refletindo sobre esses fatos e sentindo os problemas que eles suscitavam. E, assim, estariam fazendo parte do grande corpo de pesquisadores educacionais em que se deve transformar toda a profissão do magistério.

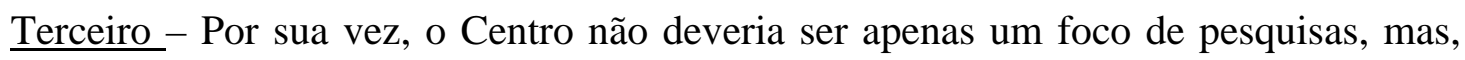
um núcleo de preparação de material de ensino, compreendido nesta expressão, tudo que fossem recursos materiais para a educação, desde livros, de texto e de fontes, guias e mesmo o que, nos EEUU, se chama de instruction materials, isto é, material de laboratório e de classe. 
O Centro manteria setores de a) leitura, escrita e matemática; b) ciências; c) ciências sociais: d) artes industriais; e) desenho, etc. etc. Cada um desses setores estaria trabalhando na produção não tanto de métodos quando de $\underline{\text { meios, }}$ recursos e expedientes de ensino. Creio que Você tem aí os guias de ensino primário do Distrito Federal, que fiz republicar. Adaptar e desenvolver tais guias para S. Paulo parecia-me um grande trabalho a que o Centro poderia desde já dedicar-se. Examine esses guias e veja como são interessantes e atuais. Tudo estava em adaptá-los com bibliografias de hoje para S. Paulo.

No campo das ciências na escola primária, poderia V. imaginar absorver a seção de ciências do IBECC daí e montar uma seção de ciências nas escolas normais e nas escolas primárias que poderia se fazer algo de revolucionário, mostrando como se poderia hoje fazer uma iniciação científica na escola primária. Mando-lhe estas idéias escritas assim ao correr da pena, para lhe significar quanto penso poder o Centro se tornar algo de concreto e prático no auxílio ao magistério e às escolas. Tudo está em substituir a idéia de reformar a escola por preceitos, ou ordens, ou determinações, ou normas, pela idéia de reformá-la pela mudança de condições, pelos nossos recursos oferecidos e pela transformação das idéias dos professores.

- Sobre D. Porcia, estou de acordo. É cedo para criar filiais. Confidencialmente, devolhe dizer que D. Porcia é um elemento de qualidade, mas, que requer uma certa reserva quanto a dar-lhe atribuições ou delegações. Quando aí estiver melhor conversarei.

Contando estar aí em novembro, sou o seu de sempre.

Anísio."

Documento pertencente ao Instituto de Estudo Brasileiros - IEB/USP. Arquivo Fernando de Azevedo, Cp, Cx. 32-A, 68, de 24 de outubro de $1956^{1}$.

\footnotetext{
${ }^{1}$ Este documento encontra-se reproduzido no livro organizado por Diana VIDAL, Na batalha da educação: correspondência entre Anísio Teixeira e Fernando de Azevedo (1929 - 1971), p. 89-91.
} 


\section{BIBLIOGRAFIA.}

\section{FONTES PRIMÁRIAS - CRPE/SP}

\subsection{Artigos da revista Pesquisa e Planejamento.}

1. ABREU, Jayme. Educação e desenvolvimento sócio-econômico da América Latina expressão de uma conferência. Pesquisa e Planejamento, São Paulo, n. 5, p. 07-40, jun. 1962.

2. ADISESHIAH, Malcolm. A UNESCO e a luta contra o analfabetismo. Pesquisa $e$ Planejamento, São Paulo, n. 2, p. 59-72, jun.1958.

3. ALGUNS característicos da escola primária no município de São Paulo, em 1958. Pesquisa e Planejamento, São Paulo, n. 3, p. 107-22, jun. 1959.

4. ANTUNHA, Elsa Lima Gonçalves. Promoção automática na escola primária. Pesquisa e Planejamento, São Paulo, n. 5, p. 97-110, jun.1962.

5. APRESENTAÇÃO. Pesquisa e Planejamento, São Paulo, n. 1, p. 01-4, jun. 1957.

6. AZANHA, José Mário Pires, BROTERO, Frederico de Barros e SINISCALCO, Lígia. Estudo experimental sobre os efeitos de alterações na forma de apresentação de problemas aritméticos. Pesquisa e Planejamento, São Paulo, n. 5, p. 188-210, jun.1962.

7. AZANHA, José Mário Pires, BROTERO, Frederico de Barros e SINISCALCO, Ligia. O rendimento na solução de problemas aritméticos na escola primária. Pesquisa $e$ Planejamento, São Paulo, n. 4, p. 127-56, jun.1960.

8. AZEVEDO, Fernando de. Luz nova sobre caminhos. Pesquisa e Planejamento, São Paulo, n. 1, p. 13-28, jun.1957.

9. ---------. Inauguração do CRPE. Pesquisa e Planejamento, São Paulo, n. 1, p.05-12, jun.1957.

10. ---------. Verdade, vida e chama. Pesquisa e Planejamento, São Paulo, n. 1, p. 103-10, jun.1957.

11. ---------. Na antevisão de um mundo só. Pesquisa e Planejamento, São Paulo, n. 2, p. 538 , jun. 1958 .

12. -------. Teoria e experiência educativa. Pesquisa e Planejamento, São Paulo, n. 2, p. 318 , jun. 1958.

13. --------. A face esquecida. Pesquisa e Planejamento, São Paulo, n. 3, p. 59-68, jun. 1959. 
14. BEISIEGEL, Celso de Rui. Aproveitamento de estatísticas educacionais em pesquisas. Pesquisa e Planejamento, São Paulo, n. 4, p. 27-35, jun.1960.

15. BOLSAS de Estudos nos Estados Unidos da América do Norte. Pesquisa e Planejamento, São Paulo, n. 2, p. 241-2, jun.1958.

16. BORTOLETTO, Maria Aparecida e CINTRA, Maria A. Rodrigues. Relatório do Curso de Psicologia da Leitura. Pesquisa e Planejamento, São Paulo, n. 1, p. 99-102, jun.1957.

17. BRACKENBURY, Robert e ANTUNHA, Heládio César Gonçalves. I Seminário para treinamento de pessoal para pesquisas educacionais. Pesquisa e Planejamento, São Paulo, n. 5, p. 224-8, jun.1962.

18. BREJON, Moysés. A ocupação dos pais dos candidatos às escolas industriais na cidade de São Paulo. Pesquisa e Planejamento, São Paulo, n. 5, p. 77-88, jun.1962.

19. BRULLÉ, Hélène. A modernização dos métodos. Pesquisa e Planejamento, São Paulo, n.4, p. 164-74, jun.1960.

20. CANDIDO, Antônio. As diferenças entre o campo e a cidade e o seu significado para a educação. Pesquisa e Planejamento, São Paulo, n. 1, p. 51-66, jun.1957.

21. CARDOSO, Ruth Corrêa Leite. Associações de "nissei" em São Paulo. Pesquisa e Planejamento, São Paulo, n. 3, p. 154-60, jun.1959.

22. CURSO sobre educação comparada. Pesquisa e Planejamento, São Paulo, n. 4, p. 187-93, jun.1960.

23. ESCALA de Escolaridade. Pesquisa e Planejamento, São Paulo, n. 2, p. 167-232, jun.1958.

24. ESCALAS de Escolaridade. Pesquisa e Planejamento, São Paulo, n. 3, p. 148-53, jun.1959.

25. ESCALAS de Escolaridade. Pesquisa e Planejamento, São Paulo, n. 4, p. 97-101, jun. 1960.

26. FICHA de Observação de Alunos. Pesquisa e Planejamento, São Paulo, n. 2, p. 119-66, jun.1958.

27. IANNI, Octávio. Educação e mudanças institucionais. Pesquisa e Planejamento, São Paulo, n. 5, p. 41-54, jun.1962.

28. KLEIN, Joanna Mader Elazari. Estatística Educacional e Administração Escolar. Pesquisa e Planejamento, São Paulo, n. 3, p. 43-9, jun.1959.

29. ---------. O Inspetor Escolar do Estado de São Paulo. Pesquisa e Planejamento, São Paulo, n. 3, p. 123-47, jun. 1959. 
30. ----------. Problemas de Ensino Primário vistos pelo Inspetor Escolar. Pesquisa $e$ Planejamento, São Paulo, n. 4, p. 82-96, jun.1960.

31. ---------. Subsídios para um planejamento da inspeção do ensino primário. Pesquisa e Planejamento, São Paulo, n. 4, p. 15-26, jun.1960.

32. LEITE, Dante Moreira. Análise de conteúdo dos livros de leitura da escola primária. Pesquisa e Planejamento, São Paulo, n. 4, p. 102-26, jun.1960.

33. LEVANTAMENTO do Ensino Primário: primeiros resultados. Pesquisa e Planejamento, São Paulo, n. 2, p. 103-18, jun.1958.

34. LEVANTAMENTO do Ensino Primário: procedimentos. Pesquisa e Planejamento, São Paulo, n. 2, p. 73-102, jun.1958.

35. LEVANTAMENTO do Ensino Primário: resultados relativos à escola. Pesquisa $e$ Planejamento, São Paulo, n. 4, p. 57-81, jun.1960.

36. LEVANTAMENTO do Ensino Primário do Estado de São Paulo. Pesquisa e Planejamento, São Paulo, n. 1, p. 111-20, jun.1957.

37. LEVANTAMENTO do Ensino Secundário e Normal do Estado de São Paulo. Pesquisa e Planejamento, São Paulo, n. 2, p. 233-40, jun.1958.

38. MANIFESTO dos Educadores: Mais uma vez convocados - Manifesto ao povo e ao Governo. Pesquisa e Planejamento, São Paulo, n. 3, p. 75-106, jun.1959.

39. MARTINS, Joel. Relatório do I Seminário. Pesquisa e Planejamento, São Paulo, n. 1, p. 87-93, jun.1957.

40. MARTINS, Wilson. O novo Emílio - o que a educação pode esperar das ciências sociais. Pesquisa e Planejamento, São Paulo, n. 1, p. 29-50, jun.1957.

41. MOREIRA, Renato Jardim. Pesquisa e Política Educacional. Pesquisa e Planejamento, São Paulo, n. 3, p. 35-42, jun.1959.

42. ---------. Planejamento educacional para o Estado de São Paulo. Pesquisa e Planejamento, São Paulo, n. 4, p. 07-14, jun.1960.

43. NOVO Convênio. Pesquisa e Planejamento, São Paulo, n. 5, p. 221-3, jun. 1961.

44. PIMENTA, Dinah de Mattos e BUENO, Haydée Pereira. Relatório do Curso de Matemática. Pesquisa e Planejamento, São Paulo, n. 1, p. 94-8, jun.1957.

45. PRIMEIRO Seminário para Treinamento de Pessoa para Pesquisas Educacionais. Pesquisa e Planejamento, São Paulo, n. 5, p. 219, jun.1962.

46. PROJETO de Escalas de Escolaridade. Pesquisa e Planejamento, São Paulo, n. 1, p. 1316, jun. 1957. 
47. PROJETO Maior n. ${ }^{1}$ da UNESCO. Pesquisa e Planejamento, São Paulo, n. 2, p. 245-59, jun.1958.

48. ROVERATTI, Haydée Maria e SILVA, José Fábio Barbosa da. Experiência de técnicas modernas numa escola tradicional. Pesquisa e Planejamento, São Paulo, n. 4, p. 36-46, jun.1960.

49. SESSÕES de Estudos para Delegados de Ensino. Pesquisa e Planejamento, São Paulo, n. 2, p. 243-4, jun.1958.

50. SESSÕES de Estudos para Inspetores Escolares. Pesquisa e Planejamento, São Paulo, n. 3, p. 161-70, jun.1959.

51. SILVA, José Fábio Barbosa da. Fontes e falhas nas informações sobre matrícula na escola primária. Pesquisa e Planejamento, São Paulo, n. 3, p. 50-8, jun.1959.

52. TEIXEIRA, Anísio. Ciência e Arte de Educar. Pesquisa e Planejamento, São Paulo, n. 1, p. 67-86, jun.1957.

\subsection{Artigos da revista Educação e Ciências Sociais.}

1. ABREU, Jayme. Observações preliminares a respeito do Projeto 4.132 C, de 1954, que dá novo texto à lei orgânica do ensino secundário brasileiro. Educação e Ciências Sociais, Rio de Janeiro, n. 5, p. 233-55, ago.1957.

2. ---------. A luta contra a escola pública brasileira. Educação e Ciências Sociais, Rio de Janeiro, n. 9, p. 57-63, dez.1958.

3. CANDIDO, Antônio. A estrutura da escola. Educação e Ciências Sociais, Rio de Janeiro, n. 2, p. 139-62, ago.1956.

4. DIVISÃO de Aperfeiçoamento do Magistério. Educação e Ciências Sociais, Rio de Janeiro, n. 8, p. 133-95, ago.1958.

5. OS ESTUDOS e as pesquisas educacionais no Ministério da Educação e Cultura. Educação e Ciências Sociais, Rio de Janeiro, n. 1, p. 05-60, mar.1956.

6. FERNANDES, Florestan. A situação brasileira e a educação. Educação e Ciências Sociais, Rio de Janeiro, n. 4, p. 300-13, mar.1957.

7. --------. O homem e a cidade-metrópole. Educação e Ciências Sociais, Rio de Janeiro, n. 11, p. 23-43, ago.1959.

8. ---------. Sobre o debate em torno na lei de diretrizes e bases da educação. Educação $e$ Ciências Sociais, Rio de Janeiro, n. 16, p. 03-8, abr.1961.

9. IANNI, Octávio. Condições sociais do ensino democrático. Educação e Ciências Sociais, Rio de Janeiro, n. 12, p. 57-87, nov.1959. 
10. LAMBERT, Jacques. Comentários sobre o programa do Centro Brasileiro de Pesquisas Educacionais. Educação e Ciências Sociais, Rio de Janeiro, n. 3, p. 11-20, dez.1956.

11. ORIENTAÇÃO do programa do CBPE para 1956 e 1957. Educação e Ciências Sociais, Rio de Janeiro, n. 3, p. 05-10, dez.1956.

12. PLANEJAMENTO Educacional. Educação e Ciências Sociais, Rio de Janeiro, n. 20, p. 03, ago.1962.

13. PLANEJAMENTO Integral da Educação. Educação e Ciências Sociais, Rio de Janeiro, n. 18, p. 11, dez.1961.

14. PROJETO de pesquisa sobre os processos de industrialização e urbanização. Educação e Ciências Sociais, Rio de Janeiro, n. 11, p. 113-8, ago.1959.

15. REUNIÕES preparatórias do Simpósio sobre Problemas Educacionais. Educação e Ciências Sociais, Rio de Janeiro, n. 5, p. 269, ago.1957.

16. SEGUNDA sessão da Comissão Consultiva dos Centros de Pesquisas Educacionais. Educação e Ciências Sociais, Rio de Janeiro, n. 8, P. 03-5, ago.1958.

17. SEMINÁRIO Interamericano de Planejamento Integral da Educação. Educação e Ciências Sociais, Rio de Janeiro, n. 8, p. 151-61, ago.1958.

18. TEIXEIRA, Anísio. Por que especialistas em Educação?. Educação e Ciências Sociais, Rio de Janeiro, n. 7, p. 05-8, abr.1958.

19. --------. Sobre o debate em torno na lei de diretrizes e bases da educação. Educação $e$ Ciências Sociais, Rio de Janeiro, n. 9, p. 05-9, dez.1958.

20. ----------. A escola particular e a escola pública. Educação e Ciências Sociais, Rio de Janeiro, n. 12, p. 87, nov.1959.

21. ----------. Tentativa de transação entre pontos de vista realmente antagônicos. Educação $e$ Ciências Sociais, Rio de Janeiro, n. 14, p. 111, jun.1960.

22. --------. Educação e desenvolvimento. Educação e Ciências Sociais, Rio de Janeiro, n. 16, p. 09-49, abr.1961.

23. THELEN, Herbert A. e GETZELS, Jacob. W. As Ciências Sociais: um esquema conceitual para a educação. Educação e Ciências Sociais, Rio de Janeiro, n. 10, p. 91-107, abr.1959.

\subsection{Artigos da Revista Brasileira de Estudos Pedagógicos.}

1. AÇÃO do INEP e Centros de Pesquisas no quinquênio 1956-1960. Revista Brasileira de Estudos Pedagógicos, Rio de Janeiro, v. 35, n. 81, p. 93-135, jan./mar.1961. 
2. CENTRO Brasileiro de Pesquisas Educacionais. Revista Brasileira de Estudos Pedagógicos, Rio de Janeiro, v. 25, n. 61, p. 145-53, jan./mar.1956.

3. KLINEBERG, Otto. Centro Brasileiro de Pesquisas Educacionais. Revista Brasileira de Estudos Pedagógicos, Rio de Janeiro, v. 24, n. 59, p.118-36, jul./set. 1955.

4. TEIXEIRA, Anísio. Discurso de posse do Professor Anísio Teixeira no Instituto Nacional de Estudos Pedagógicos. Revista Brasileira de Estudos Pedagógicos, Rio de Janeiro, v. 17, n. 46, p. 69-79, abr./jun. 1952.

\subsection{Artigos da série Estudos e Documentos.}

1. AZEVEDO, Fernando de. Educação e mudança social. Estudos e Documentos, São Paulo, n. 6, p. 131-51, 1968.

2. BREJON, Moysés. Rendimento e deficiências do Ensino Industrial brasileiro. Estudos e Documentos, São Paulo, n. 6, p. 79-100, 1968.

3. CARDOSO, Fernando Henrique e IANNI, Octávio. As exigências educacionais do processo de industrialização. Estudos e Documentos, São Paulo, n. 6, p. 197-235, 1968.

4. CARDOSO, Ruth Corrêa Leite. Necessidades educacionais de áreas em urbanização. Estudos e Documentos, São Paulo, n. 6, p. 185-96, 1968.

5. FERNANDES, Florestan. A ciência aplicada e a educação como fatores de mudança cultural provocada. Estudos e Documentos, São Paulo, n. 5, p. 09-74, 1967.

6. LEITE, Dante Moreira. A investigação psicológica face à educação brasileira. Estudos e Documentos, São Paulo, n. 5, p. 75-104, 1967.

7. MASCARO, Carlos Corrêa. O custeio da educação e a utilização de recursos para as reformas educacionais. Estudos e Documentos, São Paulo, n. 5, p. 171-93, 1967.

8. MONTEIRO, Duglas Teixeira. Necessidades educacionais de áreas em expansão demográfica da sociedade brasileira: o norte do Paraná. Estudos e Documentos, São Paulo, n. 6, p. 153-62, 1968.

9. MOREIRA, Renato Jardim. A investigação social diante dos problemas educacionais brasileiros. Estudos e Documentos, São Paulo, n. 5, p. 105-15, 1967.

10. NASSAR, Raja. Rendimento e deficiências do Ensino Secundário brasileiro. Estudos e Documentos, São Paulo, n. 6, p. 25-78, 1968.

11. PEREIRA, Luiz. Rendimentos e deficiências do Ensino Primário brasileiro. Estudos e Documentos, São Paulo, n. 6, p. 11-24, 1968.

12. RIBEIRO, José Querino. O problema da administração na formação e no desenvolvimento do sistema escolar brasileiro. Estudos e Documentos, São Paulo, n. 5, p. 137-70, 1967. 
13. RODRIGUES, Milton da Silva. Problemas atuais do ensino superior no Brasil. Estudos e Documentos, São Paulo, n. 6, p. 101-28, 1968.

14. SCHADEN, Egon. A escola teuto-brasileira e a assimilação de imigrantes alemães e seus descendentes. Estudos e Documentos, São Paulo, n. 6, p. 163-83, 1968.

15. VILLALOBOS, João Eduardo. O problema dos valores na formação e no funcionamento do sistema educacional brasileiro. Estudos e Documentos, São Paulo, n. 5,p. 116-35, 1967.

\subsection{Artigos de jornais.}

1. AZEVEDO, Fernando de. Ressente-se nosso país da falta de uma política educacional definida. Folha da Tarde, 13 dez. 1957.

2. MOREIRA, Renato Jardim. Diagnóstico do ensino primário paulista. O Estado de $S$. Paulo, 05 jun. 1960.

3. ---------. Reconstrução do ensino primário paulista. O Estado de S. Paulo, 31 jul. 1960.

\subsection{Fontes selecionadas do Arquivo Histórico do INEP.}

1. AZEVEDO, Fernando de. Carta a Anísio Teixeira, de 24 de janeiro de 1957. Arquivo Histórico do INEP, Brasília (DF), caixa 30, maço 549, pasta 01.

2. RELATÓRIO de Atividades do Centro Regional de Pesquisas Educacionais de São Paulo 1956. Arquivo Histórico do INEP, Brasília (DF), caixa 30, maço 549, pasta 01.

3. RELATÓRIO de Atividades do Centro Regional de Pesquisas Educacionais de São Paulo 1957. Arquivo Histórico do INEP, Brasília (DF), caixa 29, maço 541, pasta 01.

4. RELATÓRIO de Atividades do Centro Regional de Pesquisas Educacionais de São Paulo 1958. Arquivo Histórico do INEP, Brasília (DF), caixa 29, maço 541, pasta 01.

5. RELATÓRIO de Atividades do Centro Regional de Pesquisas Educacionais de São Paulo 1959. Arquivo Histórico do INEP, Brasília (DF), caixa 29, maço 536, pasta 01.

6. RELATÓRIO de Atividades do Centro Regional de Pesquisas Educacionais de São Paulo 1956 a 1960. Arquivo Histórico do INEP, Brasília (DF), caixa 26, maço 502, pasta 01.

7. RELATÓRIO de Atividades do Centro Regional de Pesquisas Educacionais de São Paulo 1961. Arquivo Histórico do INEP, Brasília (DF), caixa 04, maço 25, pasta 01.

8. TERMO de acordo celebrado entre o INEP, do Ministério da Educação e Cultura, e a Reitoria da USP, para a manutenção do Centro Regional de Aperfeiçoamento do Magistério de São Paulo. Arquivo Histórico do INEP, Brasília (DF), caixa 05, maço, 32, pasta 01. 


\subsection{Fontes selecionadas do Arquivo Fernando de Azevedo - Instituto de Estudos Brasileiros (IEB/USP).}

1. AZEVEDO, Fernando de. Carta a Joel Martins, de 08 de outubro de 1959. Arquivo Fernando de Azevedo - IEB/USP, Série Atividades Profissionais, Sub-série: dossiê 2 (CRPE). FA-AP, D2, de 08/10/1959.

2. BANCO DO BRASIL. Carta ao Diretor da FFCL/USP (sobre critérios de movimentação da conta corrente do Centro). Arquivo Fernando de Azevedo - IEB/USP, Série Atividades Profissionais, Sub-série: dossiê 2 (CRPE). FA-AP, D2, de 29/12/1955.

3. MARTINS, Joel. Carta a Fernando de Azevedo, de 05 de novembro de 1959. Arquivo Fernando de Azevedo - IEB/USP, Série Atividades Profissionais, Sub-série: dossiê 2 (CRPE). FA-AP, D2, de 05/11/1959.

4. MOREIRA, Renato Jardim. Carta a Fernando de Azevedo, de 18 de maio de 1960. Arquivo Fernando de Azevedo - IEB/USP, Série Atividades Profissionais, Sub-série: dossiê 2 (CRPE). FA-AP, D2, 49, de 18/06/1960.

5. PORTARIA $n .^{\circ} 147$ do INEP (designa Fernando de Azevedo para a direção do Centro). Arquivo Fernando de Azevedo - IEB/USP, Série Atividades Profissionais, Sub-série: dossiê 2 (CRPE). FA-AP, D2, de 29/06/1956.

6. RELAÇÃO do pessoal variável (técnico) do CRPE/SP, em 19 de junho de 1957. Arquivo Fernando de Azevedo - IEB/USP, Série Atividades Profissionais, Sub-série: dossiê 2 (CRPE). FA-AP, D2, de 16/06/1957.

7. RELATÓRIO do pessoal técnico do CRPE/SP apresentado à Fernando de Azevedo, de 21 de maio de 1960. Arquivo Fernando de Azevedo - IEB/USP, Série Atividades Profissionais, Sub-série: dossiê 2 (CRPE). FA-AP, D2, 50, de 21/05/1960.

8. TEIXEIRA, Anísio. Carta a Fernando de Azevedo (sobre reunião de 18 de agosto de 1955). Arquivo Fernando de Azevedo - IEB/USP, Série Atividades Profissionais, Subsérie: dossiê 2 (CRPE). FA-AP, D2, de 21/07/1955.

9. ----------. Carta a Fernando de Azevedo (sobre discurso de inauguração do Centro). Arquivo Fernando de Azevedo - IEB/USP, Série Correspondência Pessoal, Cx. 32-A, 63, de 05/06/56.

10. --------. Carta a Fernando de Azevedo (sobre verba para despesas de representação). Arquivo Fernando de Azevedo - IEB/USP, Série Atividades Profissionais, Sub-série: dossiê 2 (CRPE). FA-AP, D2, de 28/05/1956.

11. -------. Carta a Fernando de Azevedo (sobre pesquisa educacional). Arquivo Fernando de Azevedo - IEB/USP, Série Correspondência Pessoal, Cx. 32-A, 68, de 24/10/56. 
1.9. Fontes selecionadas do Centro de Memória da Educação (Faculdade de Educação/USP).

1. AZANHA, José Mario Pires. O método científico (DEPE/1958). Arquivo CRPE - Centro de Memória/USP, DEPES, PS, caixa 2, docto. 24.

2. AZEVEDO, Fernando de. Curriculum Vitae. Arquivo CRPE - Centro de Memória/USP, CM, Dossiê 2, docto. 6 .

3. --------- Da descrença para a realização: 10. Aniversário do CRPE. Arquivo CRPE Centro de Memória/USP, CM, Dossiê 2, docto. 5.

4. ---------. Pelos caminhos da Educação Nova (Oração inaugural proferida a 17 de março de 1958, na abertura do Curso de Formação de Especialistas em Educação). Arquivo CRPE Centro de Memória/USP, CM, Dossiê 2, docto. 2.

5. --------. Na pesquisa das raízes de uma instituição (INEP). Arquivo CRPE - Centro de Memória/USP, CM, Dossiê 2, docto. 1.

6. BREJON, Moysés. Rendimentos e deficiências do ensino industrial brasileiro. Arquivo CRPE - Centro de Memória/USP, DEPES, PS, caixa 1, docto. 18.

7. CANDIDO, Antonio. As diferenças entre o campo e a cidade e o seu significado para a Educação. Arquivo CRPE - Centro de Memória/USP, DEPES, PS, caixa 1, docto. 1.

8. --------. A estrutura da escola. Arquivo CRPE - Centro de Memória/USP, DAM, COP, caixa 1, docto. 12 .

9. CURSOS oferecidos de 1957 a 1972. Arquivo CRPE - Centro de Memória/USP, DAM, COP, caixa 1, docto. 2 .

10. CURSOS oferecidos de 1957 a 1972 (Relação de alunos). Arquivo CRPE - Centro de Memória/USP, DAM, COP, caixa 1, docto. 1.

11. FICHA de Observação de Alunos (cópia do instrumento/1957). Arquivo CRPE - Centro de Memória/USP, DEPES, PAT, caixa 3, docto. 46.

12. NASSAR, Raja. Rendimentos e deficiências do ensino secundário brasileiro. Arquivo CRPE - Centro de Memória/USP, DEPES, PS, caixa 1, docto. 17.

13. PEREIRA, Luiz. Rendimentos e deficiências do ensino primário brasileiro. Arquivo CRPE - Centro de Memória/USP, DEPES, PS, caixa 1, docto. 3.

14. ---------. Nota crítica sobre o pensamento pedagógico brasileiro. Arquivo CRPE - Centro de Memória/USP, DEPES, PS, caixa 1, docto. 5.

15. PLANO de Organização do Centro Brasileiro de Pesquisas Educacionais e Centros Regionais e de aplicação da verba global destinada no orçamento de 1956 a Centros de 
Aperfeiçoamento do Magistério. Arquivo CRPE - Centro de Memória/USP, SD, CD, caixa 2, docto. 26.

16. PLANO de Organização do Centro Regional de Pesquisas Educacionais de São Paulo com instruções de Serviço. Arquivo CRPE - Centro de Memória/USP, SD, CD, caixa 1, docto. 13.

17. PORTARIA de maio de 1956, aprova o Plano de Trabalho do Centro Regional de Pesquisas Educacionais de São Paulo. Arquivo CRPE - Centro de Memória/USP, SD, CD, caixa 2, docto. 20.

18. PROGRAMA de pesquisas para 1961. Arquivo CRPE - Centro de Memória/USP, DEPES, PAT, caixa 1, docto. 6 .

19. PROJETOS para elaboração de instrumentos de observação de alunos. Arquivo CRPE Centro de Memória/USP, DEPES, PAT, caixa 3, docto. 46.

20. RELAÇÃO do pessoal do Centro Regional de Pesquisas Educacionais de São Paulo, desde 1956. Arquivo CRPE - Centro de Memória/USP, SD, CD, caixa 1, docto. 07.

21. SEMINÁRIO de Professores Primários. Instruções para o preenchimento do questionário candidatando-se ao Seminário de Professores Primários. Arquivo CRPE - Centro de Memória/USP, DEPES, PS, caixa 1, docto. 6.

22. TERMO de acordo celebrado entre o Instituto Nacional de Estudos Pedagógicos, do Ministério da Educação e Cultura, e a Reitoria da Universidade de São Paulo, para a instalação e manutenção do Centro Regional de Pesquisas Educacionais de São Paulo (22/05/1956). Arquivo CRPE - Centro de Memória/USP, SD, CD, caixa 2, docto. 20.

23. TERMO de acordo celebrado entre o Instituto Nacional de Estudos Pedagógicos, do Ministério da Educação e Cultura, e a Reitoria da Universidade de São Paulo, para a instalação e manutenção do Centro Regional de Pesquisas Educacionais de São Paulo (31/08/1961). Arquivo CRPE - Centro de Memória/USP, SD, CD, caixa 2, docto. 18.

\subsection{Fontes selecionadas do Arquivo Anísio Teixeira (CPDOC/FGV).}

1. CENTRO Brasileiro de Pesquisas Educacionais. Objetivos e organização do CBPE e Centros Regionais, Rio de Janeiro. FGV/CPDOC - Arquivo Anísio Teixeira, Atpi CBPE 1956/1964.00.00.

2. TEIXEIRA, Anísio. Carta a Cândido Mota Filho, [Rio de Janeiro?], dez. 1954. FGV/CPDOC - Arquivo Anísio Teixeira, ATc 54.12.00. 
3. -------. Carta a Shanon McCune, [Rio de Janeiro?], 18 set. 1961, FGV/CPDOC Arquivo Anísio Teixeira, Atc 61.09.18.

4. --------. Carta a Isnar de Freitas, Rio de Janeiro, 19 set. 1961, FGV/CPDOC - Arquivo Anísio Teixeira, Atc 61.09.19.

\section{FONTES PRIMÁRIAS - ISEB.}

1. CORBISIER, Roland. Formação e Problema da Cultura Brasileira. 3. a edição. Rio de Janeiro, ISEB, 1960. 112p.

2. JAGUARIBE, Hélio. Condições institucionais do desenvolvimento. Rio de Janeiro, ISEB, 1958. 53p.

3. --------. O nacionalismo na atualidade brasileira. Rio de Janeiro, ISEB, 1958. 305p.

4. PINTO, Álvaro Vieira. Consciência e realidade nacional. Rio de Janeiro, ISEB, 1960. vol.2, 639p.

5. --------. Ideologia e desenvolvimento nacional. Rio de Janeiro, ISEB, 1960. 52p.

\section{FONTES SECUNDÁRIAS.}

\subsection{Monografias.}

1. ALMEIDA, Maria Hermínia Tavares de. Dilemas da institucionalização das ciências sociais no Rio de Janeiro. In: MICELI, Sérgio. História das ciências sociais no Brasil. São Paulo, Vértice/IDESP, 1989. vol.1, p. 188-216.

2. ARRUDA, Maria Arminda do Nascimento. A sociologia no Brasil: Florestan Fernandes e a escola paulista. In: MICELI, Sérgio. História das ciências sociais no Brasil. São Paulo, Editora Sumaré/FAPESP, 1995. vol. 2, p. 107-231.

3. BARROS, Edgard Luiz. O Brasil de 1945 a 1964. 5. ${ }^{\text {a }}$ edição. São Paulo, Contexto, 1977. 78p.

4. BEISIEGEL, Celso de Rui. Estado e Educação Popular (um estudo sobre a educação de adultos). São Paulo, Livraria Pioneira Editora, 1974. 189p.

5. --------. Política e Educação Popular. 3. a edição. São Paulo, Editora Ática, 1992. 304p.

6. BENEVIDES, Maria Victoria M. O Governo Kubitschek: desenvolvimento econômico e estabilidade política (1956-1961). 3. a edição. Rio de Janeiro, Paz e Terra, 1979. 302p.

7. CARDOSO, Miriam Limoeiro. Ideologia do desenvolvimento no Brasil: JK-JQ. 2. ${ }^{\mathrm{a}}$ edição. Rio de Janeiro, Paz e Terra, 1978. 459p. 
8. CORRÊA, Mariza. História da Antropologia no Brasil: 1930-1960, testemunhos. São Paulo, Vértice/Editora dos Tribunais, 1987. 127p.

9. CUNHA, Marcus Vinicius da. Indivíduo e sociedade no ideário escolanovista (Brasil: 1930-60). São Paulo, Faculdade de Educação/USP, 1992. 339p. (Tese, Doutorado em Educação).

10. FERNANDES, Florestan. Atitudes e Motivações Desfavoráveis ao Desenvolvimento. In: Mudanças Sociais no Brasil: aspectos do desenvolvimento na sociedade brasileira. São Paulo, Difusão Européia do Livro, 1960. p. 11-49.

11. ---------. O Centro Brasileiro de Pesquisas Educacionais. In: Educação e Sociedade no Brasil. São Paulo, Dominus/Edusp, 1966. p. 565-78.

12. ---------. Florestan Fernandes. Brasília, INEP, 1991. (Coleção Memória viva da educação brasileira n. ${ }^{\circ}$ 1).

13. FRANCO, Maria Sylvia de Carvalho. O tempo das ilusões. In: CHAUÍ, Marilena. Ideologia e mobilização popular. Rio de Janeiro, Paz e Terra, 1978. p. 151-209.

14. FREITAS, Marcos Cezar de. A pesquisa educacional como questão intelectual na história da educação brasileira. In: FREITAS, Marcos Cesar (org.). Memória intelectual da educação brasileira. Bragança Paulista, Editora da Universidade São Francisco/EDUSF, 1999. p. 65-84.

15. ---------. Da idéia de regional no projeto do Centro Regional de Pesquisas Educacionais de São Paulo. São Paulo, Faculdade de Educação/USP), 2000, 101p. (Pós Doutorado).

16. KONDER, Leandro. História dos intelectuais nos anos cinquenta. In: FREITAS, Marcos Cezar de (org.). Historiografia brasileira em perspectiva. 2. ${ }^{a}$ edição. São Paulo, Contexto, 1998. p. 355-74.

17. LIMA, Hermes. Anísio Teixeira: estadista da educação. Rio de Janeiro, Civilização Brasileira, 1978.

18. MARIANI, Maria Clara. Educação e Ciências Sociais: o Instituto Nacional de Estudos e Pesquisas Educacionais. In: SCHWARTZMAN, Simon (org.). Universidades e instituições científicas no Rio de Janeiro, Brasília, CNPq, 1982. p. 169-95.

19. MENDONÇA, Ana Waleska e BRANDÃO, Zaia (org.). Por que não lemos Anísio Teixeira? Uma tradição esquecida. Rio de Janeiro, Ravil, 1997. 211p.

20. MICELI, Sérgio. Por uma sociologia das ciências sociais. In: História das ciências sociais no Brasil. São Paulo, Vértice/IDESP, 1989. vol. 1, p. 05-19.

21. MOREIRA, Antonio Flávio Barbosa. A Universidade de Darcy Riberio e o nacionalismo desenvolvimentista. In: TUBINO, Manoel José Gomes (org.). A universidade ontem e hoje. São Paulo, IBRASA, 1984. p. 110-25. 
22. MOTA, Carlos Guilherme. Ideologia da cultura brasileira. 9. ${ }^{a}$ edição. São Paulo, Editora Ática, 1994. 303p.

23. NUNES, Clarice. Anísio Teixeira: A poesia da ação. Bragança Paulista, EDUSF, 2000. $644 \mathrm{p}$.

24. PAOLI, Niuvenius Junqueira. As relações entre Ciências Sociais e Educação nos anos 50/60 a partir das histórias intelectuais de quatro personagens (Josildeth Gomes Consorte, Aparecida Joly Gouveia, Juarez Brandão Lopes e Oracy Nogueira). São Paulo, Faculdade de Educação/USP, 1995. (Tese, Doutorado em Educação).

25. PÉCAUT, Daniel. Os intelectuais e a política no Brasil: entre o povo e a nação. São Paulo, Editora Ática, 1990. 335p. (trad. de Maria Júlia Goldwasser, Entre le peuple et la nation: les intellectuels et la politique au Brésil, Fondation de la Maison des Sciences de l'Homme, 1989).

26. PEREIRA, Luiz. A escola primária numa área metropolitana. 2. edição. São Paulo, Livraria Pioneira Editora/Editora da Universidade de São Paulo, 1967. 166p.

27. SAAVEDRA, Silvia Maria Galliac. Passos e descompassos de uma instituição de pesquisa educacional no Brasil: a realidade do INEP. Brasília, Universidade de Brasília, 1988. (Dissertação, Mestrado em Educação).

28. SKIDMORE, Thomas E. Brasil, de Getúlio Vargas a Castelo Branco (1930-1964). 7. edição. Rio de Janeiro, Paz e Terra, 1982. 512p.

29. TOLEDO, Caio Navarro de. ISEB: fábrica de ideologias. 2. ${ }^{\text {a }}$ edição. Campinas, Editora da UNICAMP, 1997. 218p.

30. VIDAL, Diana Gonçalves (org.). Na batalha da educação: correspondência entre Anísio Teixeira e Fernando de Azevedo (1929-1971). Bragança Paulista, EDUSF, 2000. 215p.

31. VIEIRA, Evaldo. Estado e miséria social no Brasil: de Getúlio a Geisel (1951-1978). 4. ${ }^{a}$ edição. São Paulo, Cortez Editora, 1983. 240p.

32. XAVIER, Libânia Nacif. A pesquisa do CBPE em revista. In: MENDONÇA, Ana Waleska e BRANDÃO, Zaia (org.). Por que não lemos Anísio Teixeira? Uma tradição esquecida. Rio de Janeiro, Ravil, 1997. p. 83-139.

33. --------. O Brasil como laboratório: educação e ciências sociais no projeto do centro brasileiro de pesquisas educacionais. Bragança Paulista, IFAN/CDAP/EDUSF, 1999. 281p.

\subsection{Artigos de Revistas.}

1. CORRÊA, Mariza. A Revolução dos Normalistas. Cadernos de Pesquisa, São Paulo, Fundação Carlos Chagas, n. 66, p. 13-24, ago.1988. 
2. CUNHA, Luiz Antônio. A educação na sociologia: um objeto rejeitado?. Cadernos CEDES, Campinas, n. 27, p. 09-22, 1992.

3. CUNHA, Marcus Vinicius da. A educação no período Kubitschek: os Centros de Pesquisa do INEP. Revista Brasileira de Estudos Pedagógicos, Brasília, v. 72, n. 171, p. 175-95, maio/ago. 1991.

4. --------. Três versões do pragmatismo deweyano no Brasil dos anos cinquenta. Educação e Pesquisa, São Paulo, v. 25, n. 2, p. 39-55, jul./dez. 1999.

5. FAZENDA, Ivani Catarina Arantes. O Centro Regional de Pesquisas Educacionais de São Paulo: um capítulo na História da Educação Brasileira. Cadernos de Pesquisa, São Paulo, n. 60, p. 61-5, fev. 1987.

6. FERNANDES, Florestan. Entrevista: sobre o trabalho teórico. Trans/form/ação. Faculdade de Filosofia, Ciências e Letras de Assis, Assis, n. 2, p. 05-86, 1975.

7. GOUVEIA, Aparecida Joly. A pesquisa educacional no Brasil. Cadernos de Pesquisa, São Paulo, n. 01, p. 01-47, 1971.

8. KUBINSKY, Zita. O Centro Regional de Pesquisas Educacionais do Sudeste. Pesquisa e Planejamento, São Paulo, n. 16, p. 07-33, jan.1975.

9. MARTINS, Carlos Benedito. Educação e Sociologia: uma relação possível?. Cadernos CEDES, Campinas, n. 27, p. 05-8, 1992.

10. NAGLE, Jorge. A reflexão pedagógica crítica: uma necessidade e um exemplo (a propósito da obra educacional de Dante Moreira Leite). Cadernos de Pesquisa, São Paulo, n. 17, p. 13-40, jun. 1976.

\subsection{Artigos de Jornais.}

1. FUNDAMENTAL o conhecimento objetivo do aluno para qualquer reforma educacional. Folha da Noite, 04 out. 1957. [Arquivo CRPE - Centro de Memória/USP, SD, CD, caixa 1, docto. 1-6/8(3)].

2. INAUGURA-SE hoje o Centro Regional de Pesquisas Educacionais de São Paulo. $O$ Estado de S. Paulo, 12 jun. 1956. [Arquivo CRPE - Centro de Memória/USP, SD, CD, caixa 1, docto. 1-3/8(2)].

3. INAUGURADO ontem o Centro Regional de Pesquisas Educacionais de São Paulo. $O$ Estado de S. Paulo, 13 jun. 1956. [Arquivo CRPE - Centro de Memória/USP, SD, CD, caixa 1, docto. 1-9/1(1)]. 
4. INAUGURADO ontem o Centro Regional de Pesquisas Educacionais de São Paulo. Folha da Manhã, 13 jun. 1956. [Arquivo CRPE - Centro de Memória/USP, SD, CD, caixa 1, docto. $1-5 / 8(2)]$.

5. JANTAR em homenagem ao ex-diretor do DEPS. O Estado de S. Paulo, 26 jun. 1960.

6. PEQUENA revolução pedagógica: o Centro de Pesquisas Educacionais. Folha da Noite, 01 out. 1957. [Arquivo CRPE - Centro de Memória/USP, SD, CD, caixa 1, docto. 1-6/8(1)].

7. PESQUISA científica para a solução dos problemas da educação no país. Diário de $S$. Paulo, 13 jun. 1956. [Arquivo CRPE - Centro de Memória/USP, SD, CD, caixa 1, docto. $1-9 / 1(2)]$.

8. PESQUISAS sociais e educacionais. O Estado de S. Paulo, 15 jul. 1956. Notas e informações. [Arquivo CRPE - Centro de Memória/USP, SD, CD, caixa 1, docto. 1$3 / 8(1)]$.

9. PROFESSORES iniciam um grande debate sobre os problemas atuais da educação no Brasil. O Estado de S. Paulo, 02 set. 1959. http: //www.prossiga.br/anisioteixeira.

10. O QUE se dá aos Centros não se subtrai, mas se acrescenta à solução dos problemas educacionais. Folha da Noite, 03 out. 1957. [Arquivo CRPE - Centro de Memória/USP, $\mathrm{SD}, \mathrm{CD}$, caixa 1 , docto. 1-6/8(2)].

\subsection{Obras de Referência.}

1. ABREU, Alzira e BELOCH, Israel (org.). Dicionário Histórico Biográfico Brasileiro. Rio de Janeiro, CPDPC/FGV, 1983.

2. FÁVERO, Maria de Lourdes de Albuquerque e BRITTO, Jader de Medeiros (org.). Dicionário de educadores no Brasil. Rio de Janeiro, Editora UFRJ/MEC-INEP, 1999. 


\section{Créditos da autora.}

Márcia dos Santos Ferreira é formada em Sociologia e Antropologia pelo Instituto de Filosofia e Ciências Humanas da Universidade de Campinas/UNICAMP (1997).

Correspondência: R. Dr. Silvio Dante Bertacchi, 1289. CEP: 05625-001. São Paulo (SP).

E-Mail: mafer@fe.usp.br 